\title{
BUILDING A BRIDGE BETWEEN INUNDATED SHORES: ANALYSES ON INTEGRATED DISASTER RISK MANAGEMENT AND CLIMATE CHANGE ADAPTATION POLICIES AND MEASURES
}

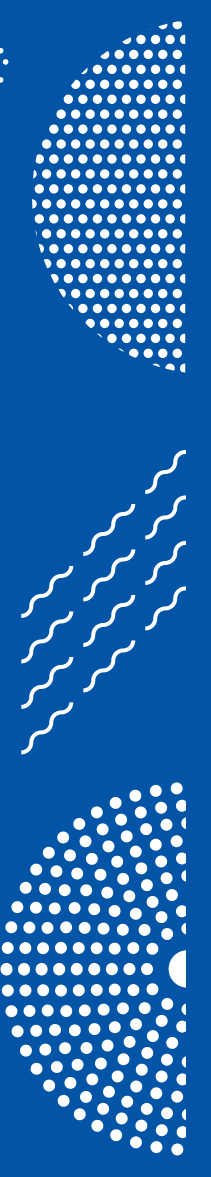




\title{
Building a Bridge between Inundated Shores: Analyses on integrated Disaster Risk Reduction and Climate Change Adaptation Policies and Measures
}

\author{
Karoliina Pilli-Sihvola
}

Doctoral Programme in Sustainable Use of Renewable Natural Resources

Faculty of Agriculture and Forestry University of Helsinki

Helsinki, Finland

ACADEMIC DISSERTATION in Environmental Economics

To be presented, with the permission of the Faculty of Agriculture and Forestry of the University of Helsinki, for public criticism in auditorium PII at Porthania (Yliopistonkatu 3, Main Campus, Helsinki) on June 17, 2020, at 12 noon.

Finnish Meteorological Institute

Helsinki, 2020 
Supervisors

Reviewers

Custos

Opponent
Research Professor Adriaan Perrels

Weather and Climate Change Impact Research

Finnish Meteorological Institute, Finland

Professor Markku Ollikainen

Faculty of Agriculture and Forestry

University of Helsinki, Finland

Group head, Dr. Heikki Tuomenvirta

Weather and Climate Change Impact Research

Finnish Meteorological Institute, Finland

Professor Christer Pursiainen

Department of Technology and Safety

The Arctic University of Norway, Norway

Professor Ilan Noy

School of Economics and Finance

Victoria Business School, New Zealand

Professor Kari Hyytiäinen

Faculty of Agriculture and Forestry

University of Helsinki, Finland

Research director, Dr. Jaroslav Mysiak

Risk Assessment and Adaptation Strategies Division

Euro-Mediterranean Centre on Climate Change

(CMCC), Italy

ISBN 978-952-336-113-3 (paperback)

ISBN 978-952-336-114-0 (pdf)

ISSN 0782-6117

Edita Prima Oy

Helsinki 2020 
Published by Finnish Meteorological Institute

(Erik Palménin aukio 1), P.O. Box 503

FIN-00101 Helsinki, Finland

Author Karoliina Pilli-Sihvola

ORCID iD 0000-0001-6257-3910

Title

Building a Bridge between Inundated Shores: Analyses on Integrated Disaster Risk Management

and Climate Change Adaptation Policies and Measures

\begin{abstract}
This thesis consists of an introduction and four articles which analyse disaster risk management (DRM), including disaster risk reduction (DRR), disaster management and climate change adaptation (CCA) from economic and policy perspectives. The main research question is: what are the means to overcome the salient challenges in DRM and CCA policies and measures which have been designed to reduce the risks posed by extreme weather under uncertainty? Theoretically, it advances the policy level development of DRM and CCA integration and provides a mathematical definition for over-adaptation to climate change. Empirically, it analyses integrated DRM and CCA policies and measures, and analyses challenges related to their development and implementation.
\end{abstract}

Article I provides a formal definition for DRR and CCA policy integration at horizontal (inter-ministerial) and vertical (intra-ministerial) dimensions to assess DRR and CCA policy-making and analyses policies and their integration challenges in Zambia. The theoretical contribution to the literature is the formal definition for DRR and CCA policy integration and the empirical contribution is provided by evidence of potential challenges created by the governance system.

Article II discusses the contribution of the underlying vulnerability drivers of governance, societal and political factors, culture, policies and their implementation, and argues that vulnerability reduction is a key aspect in reducing disaster and climate change risk. The theoretical contribution furthers the discussion on new dimensions in climate change risk analyses by emphasising the potential impacts of societal development, such as social trends and social cohesion, in effective DRM and CCA. The article contributes to the empirical literature by assessing Nordic welfare state structures as a means to reduce disaster risk and climate change.

Article III analyses the costs and benefits of a major integrated DRM and CCA policy in Finland, and describes how over-adaptation, i.e. over-investment in DRM and CCA may affect the legitimacy of a policy aiming partially at reducing extreme weather risk. The article contributes to the theoretical literature by providing a mathematical definition for over-adaptation and to the empirical literature through the case study.

Article IV assesses the effects of a potential innovation in weather service provision to improve CCA and safety in the road transport sector. The article identifies and describes the main trends and potential innovations in the provision and use of weather services. It contributes to the empirical literature on CCA and weather service benefit valuation.

Publishing unit Finnish Meteorological Institute | Weather and Climate Change Impact Research

Classification (UDC)

33 Economics. Economic science

364.682 Environmental welfare problems

ISSN and series title

0782-6117 Finnish Meteorological Institute Contributions

OI

https://doi.org/10.35614/isbn.9789523361140
Keywords

climate change, disaster risk reduction, extreme weather, cost-benefit analysis, risk, uncertainty, efficiency, effectiveness, decision-making

ISBN

978-952-336-113-3 (paperback)

978-952-336-114-0 (pdf)

Language Pages

English 
Julkaisija Ilmatieteen laitos

(Erik Palménin aukio 1)

PL 503, 00101 Helsinki
Julkaisun sarja, numero ja raporttikoodi

Finnish Meteorological Institute Contributions 168

FMI-CONT 168

Päiväys: Kesäkuu 2020

\begin{tabular}{ll}
\hline Tekijä & Karoliina Pilli-Sihvola \\
ORCID iD & $0000-0001-6257-3910$
\end{tabular}

Nimeke Sillan rakentaminen kahden tulvineen rannan välille: Analyysejä integroitujen katastrofiriskien

hallinnan ja ilmastonmuutokseen sopeutumisen politiikoista ja toimista

\begin{abstract}
Tiivistelmä
Tämä tutkielma koostuu johdannosta ja neljästä artikkelista, joissa analysoidaan sekä katastrofiriskien hallintaa (Disaster Risk Management - DRM) että ilmastonmuutokseen sopeutumista (Climate Change Adaptation - CCA) taloustieteellisestä ja politiikka-analyysin näkökulmasta. Katastrofiriskien hallintaan sisältyvät katastrofiriskien vähentäminen (Disaster Risk Reduction - DRR) ja katastrofien hallinta (Disaster Management). DRM- ja CCApolitiikkojen tarkoituksena on vähentää äärimmäisten sääilmiöiden aiheuttamia riskejä ottaen huomioon ilmastonmuutoksen mukanaan tuoma epävarmuus. Tutkielman pääkysymys on: millä keinoin voidaan ratkaista DRM- ja CCA-politiikkoihin ja -toimiin liittyviä merkittäviä haasteita? Teoreettisesti tutkielma edistää DRM:n ja CCA:n politiikka-analyysia sekä esittää matemaattisen määritelmän ilmastomuutoksen liialliseen sopeutumiseen. Empiirisesti työssä analysoidaan integroituja DRM- ja CCA-politiikkoja ja- toimia sekä analysoidaan niiden kehittämiseen ja toteuttamiseen liittyviä haasteita.
\end{abstract}

Artikkelissa I kehitetään DRR- ja CCA-politiikkojen integroinnin muodollinen määritelmä horisontaalisessa (ministeriöiden sisäisessä) ja vertikaalisessa (ministeriöiden välisessä) ulottuvuudessa. Empiirinen osuus analysoi Sambian tilannetta ja haasteita. Teoreettinen panos kirjallisuuteen on muodollinen määritelmä DRR- ja CCApolitiikkaintegroinnille ja empiirinen panos tulee arvioista hallinnon tilanteen aiheuttamista mahdollisista haasteista.

Artikkelissa II käsitellään katastrofiriskien taustalla olevien haavoittuvuustekijöiden, kuten yhteiskunnallisten ja poliittisten tekijöiden, kulttuurin, politiikan ja niiden täytäntöönpanon vaikutusta riskien vähentämisessä. Artikkelin teoreettinen panos edistää keskustelua ilmastoriskianalyysien uusista ulottuvuuksista korostamalla yhteiskunnallisen kehityksen, kuten sosiaalisten suuntausten ja yhteenkuuluvuuden, mahdollisia vaikutuksia tehokkaassa DRM:ssä ja CCA:ssa. Artikkeli tukee empiiristä kirjallisuutta arvioimalla pohjoismaisen hyvinvointivaltion rakenteita keinona vähentää katastrofi- ja ilmastonmuutosriskiä.

Artikkelissa III analysoidaan integroidun DRM- ja CCA- politiikan kustannuksia ja hyötyjä Suomessa: Lisäksi kuvataan, kuinka liiallinen panostaminen katastrofiriskien hallintaan ja sopeutumiseen voi vaikuttaa politiikan hyväksyttävyyteen. Artikkelin teoreettinen panos tulee matemaattisen määritelmän esittämisestä liialliseen CCA:han, ja empiirinen panos tulee tapaustutkimuksen kautta.

Artikkelissa IV arvioidaan, miten innovaatiot voivat vähentää sään ääri-ilmiöiden ja ilmastonmuutoksen aiheuttamia haitallisia vaikutuksia tieliikennesektorilla. Artikkelissa tunnistetaan ja kuvataan sääpalvelujen tarjoamisen ja käytön tärkeimmät suuntaukset ja mahdolliset innovaatiot, sekä arvioidaan millaisia taloudellisia hyötyjä tieliikenteen turvallisuuden parantaminen tuo. Artikkeli on osa empiiristä CCA-kirjallisuutta ja tarjoaa esimerkin sääpalvelujen taloudellisten hyötyjen arvioinnista.

Julkaisijayksikkö IImatieteen laitos | Sään ja ilmastonmuutoksen vaikutustutkimus

Luokitus (UDK)

33 Kansantalous. Kansantaloustiede

364.682

ISSN ja avainnimeke

0782-6117 Finnish Meteorological Institute

Contributions

\section{Asiasanat}

katastrofiriskien vähentäminen, ilmastonmuutos, sopeutuminen, kustannus-hyöty-analyysi, riski, epävarmuus, tehokkuus, vaikuttavuus, päätöksenteko

\section{ISBN}

978-952-336-113-3 (nid.)

978-952-336-114-0 (pdf)

\begin{tabular}{lll}
\hline DOI & Kieli & Sivumäärä \\
https://doi.org/10.35614/isbn.9789523361140 & Englanti & 44 \\
\hline
\end{tabular}




\section{ACKNOWLEDGEMENTS}

I am writing this the night before this thesis goes to print. I started believing that this moment would only ever come a few months ago. This thesis has felt like a never-ending journey, which started in the Autumn 2008, almost 12 years ago; a time before smartphones and when Nokia was one of the largest mobile phone companies. The journey has been full of trials and tribulations, amazing experiences, a lot of tears and a burn out. Along the way, there have been a lot of people I have wanted to thank for either providing me professional support, personal support, and in the best case, both.

First, I want to thank all my supervisors: Professor Markku Ollikainen, Research Professor Adriaan Perrels and my boss at the Finnish Meteorological Institute, Heikki Tuomenvirta. Markku, you taught me how to write academic text during my first, and our only joint, article which in the end did not make into this thesis. You also provided excellent comments on the introduction. Adriaan, you included me in many interesting research projects which have shaped my career and interests and your comments have also substantially improved the introduction. Heikki, you taught me almost everything I know about physical climate change and extreme weather events. When you couldn't answer my questions, you could always find someone who could. Thanks to you, and many other meteorologists from FMI, I can fool people into think that I am a meteorologist; quite a skill for an environmental economist!

This thesis consists of two parts; the introduction and the articles. Thanks to my co-authors, the articles were the relatively easy part. Two of the articles were written in close collaboration with Väinö Nurmi. Väinö, of my colleagues you deserve my biggest gratitude. I have learnt so much from you over the years; your knowledge, skills and attitude are something I truly admire. Senja VäätäinenChimpuku, you had a tremendous impact on my career. Our joint article was an extremely smooth process, got me interested in disasters and eventually shaped this entire thesis. Atte Harjanne and Riina Haavisto, not only were we close colleagues for many years, facilitating workshops and writing reports, but we even managed to write a joint paper, for which I am very grateful.

The introduction was the hard part. For that, for the entire thesis and for the fact that I am still relatively sane after all this, my biggest, heartfelt thanks go to Dave, my husband. Dave, without you I would have given up years ago. You got me out of bed when I was struggling to go to work, you calmed me down from my panic attacks, you wiped my tears that I had too often, and you drank beer with me when that was what I needed the most. You also gave professional comments, helped me to formulate my research questions and conclusions, and patiently proof-read my articles and this thesis.

There are also a lot of former FMI colleagues and friends I want to thank for various reasons. From FMI, Athanasios Votsis, Reija Ruuhela, Sanna Luhtala, Otto Hyvärinen, Mikko Laapas, Tiina Ervasti, Juha A. Karhu and all other 
colleagues from my old group and unit deserve a big thanks. Also, many other people from FMI, whom I consider more my friends than colleagues, deserve acknowledgments: Alexey, Andreas, Curtis, Edith, Iolanda, Markus, Stelios, Svante, Timo, Toni and Ulpu. Thanks for the lunch and coffee breaks and beers that kept me going.

There have been many people who have provided me support during difficult times; perhaps often without even realising it. Special thanks go to Ainot, Anna $\mathrm{K}$. and Toni. Also, in the final stages of my thesis, there were two influential, though brief encounters which warrant recognition as they gave me the final push to finish. First, Tom H. who told me about the wise words of his own boss, who was looking forward to getting both sides of Tom's brain back in business after the thesis was written. This made me realise that indeed, this thesis has been constantly in the back of my mind, even when I was not working on it. Second, Essi, that moment on your couch when you made me think how I would feel and sense after I submit the thesis was the single most influential moment that pushed me from 'I-will-never -finish-my-thesis' to 'I-will-do-it'.

My sincere gratitude goes to the Maj and Tor Nessling Foundation who funded the first three years of my PhD studies. I also want to thank the NORDRESS; Centre of Excellence under the Social Security Programme of NordForsk, for providing me a travel grant to begin writing the thesis' introduction in Copenhagen. Thanks are due to the Copenhagen Center for Disaster Research (COPE) at the University of Copenhagen for providing me an office; Nathan, Silje and Christine for the excellent company in that office and Kristian for the spare laptop you arranged after my own broke just after I arrived. Without the five weeks in Copenhagen, this thesis would have never been written. Thanks are also due to my current employer, the National Audit Office of Finland, who supported the very final steps of my thesis by providing me leave of absence after the preexaminers granted me the permission to defend.

Professor Pursiainen and Professor Noy, many thanks for accepting the invitation to pre-examine my thesis and many thanks for the excellent comments you gave. They substantially improved the introduction. Dr. Jaroslav Mysiak; many thanks for agreeing to act as my opponent in the public defence and thank you for doing it remotely during these exceptional times.

My choices throughout my life have resembled more like a piece of driftwood than any conscious choice; my $\mathrm{PhD}$ studies and this thesis being a prime example. Nevertheless, my family-my parents Mikko and Elina and brother Matti-you have always supported me and tirelessly asked when I will finish my thesis. Thanks for not giving up.

Helsinki, May 2020

Karoliina Pilli-Sihvola 


\section{TABLE OF CONTENTS}

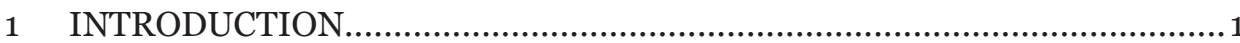

1.1 Hazards, disasters and climate change ..............................................

1.2 Research Question and Objectives..................................................5

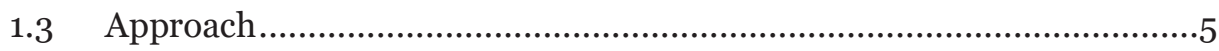

2 THEORETICAL BACKGROUND ON DISASTER AND CLIMATE RISK MANAGEMENT UNDER UNCERTAINTY............................................ 8

2.1 Disaster Risk Management and Climate Change Adaptation -Policies and Implementation ............................................................................ 8

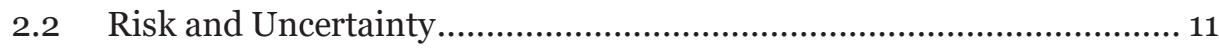

2.2.1 Probabilistic Risk Analysis................................................. 11

2.2.2 Extensions of the probabilistic risk analysis ............................. 13

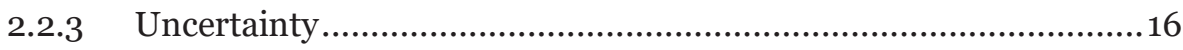

2.3 Efficiency and Effectiveness ..................................................... 18

3 APPROACH: FROM QUALITATIVE TO QUANTITATIVE ANALYSIS.......21

3.1 Mixed methods research ...........................................................21

3.2 Qualitative approach: Semi-structured interviews and policy documents 22

3.3 Quantitative approach: Cost Benefit Analysis................................ 23

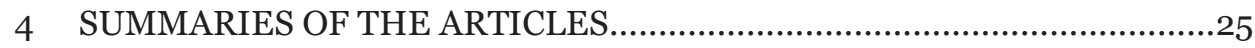

Article I: Defining Climate Change Adaptation and Disaster Risk Reduction Policy Integration: Evidence and Recommendations from Zambia...............25

Article II: Adaptation by the Least Vulnerable: Managing Climate and Disaster

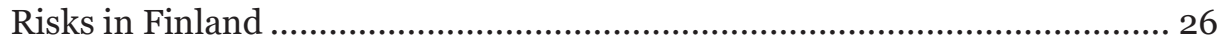

Article III: Overadaptation to Climate Change? The Case of the 2013 Finnish Electricity Market Act .27

Article IV: Innovations in weather services as a crucial building block for climate change adaptation in road transport........................................... 28

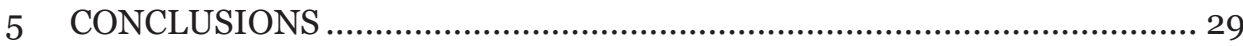

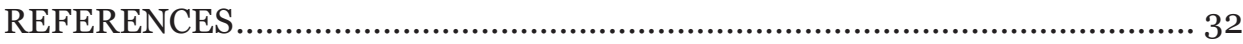




\section{LIST OF ORIGINAL PUBLICATIONS}

I. Pilli-Sihvola, Karoliina., Väätäinen-Chimpuku, Senja. 2016. Defining climate change adaptation and disaster risk reduction policy integration: Evidence and recommendations from Zambia, International Journal of Disaster Risk Reduction, 19, 461-473.

II. Pilli-Sihvola, Karoliina., Harjanne, Atte., Haavisto, Riina. 2018. Adaptation by the least vulnerable: Managing climate and disaster risks in Finland, International Journal of Disaster Risk Reduction, 31, 1266-1275

III. Nurmi, Väinö., Pilli-Sihvola, Karoliina., Gregow, Hilppa., Perrels, Adriaan. 2019. Overadaptation to Climate Change? The Case of the 2013 Finnish Electricity Market Act. Economics of Disasters and Climate Change, 3, 161-190.

IV. Pilli-Sihvola, Karoliina., Nurmi, Väinö., Perrels, Adriaan., Harjanne, Atte., Bösch, Patrick., Ciari, Francesco. 2016. Innovations in weather services as a crucial building block for climate change adaptation in road transport. European Journal of Transport and Infrastructure Research, 16, 150-173.

This thesis consists of four articles. Karoliina Pilli-Sihvola is the lead author in Articles I, II and IV. In all the articles, she has been the main contributor to the theoretical sections on Disaster Risk Reduction and Climate Change Adaptation. In Articles I and II she has been the main contributor to the analysis of the studies, in Article III she came up with the research idea, and in Articles III and IV she has contributed to the economic and uncertainty analysis. She had the main responsibility in writing Articles I and II and shared the main responsibility of writing Articles III and IV.

Article I was written as part of the Academy of Finland FICCA SAFE-MET (no:264058) project. Article II was written was supported by the Nordic Centre of Excellence for Resilience and Societal Security - NORDRESS, which is funded by the Nordic Societal Security Programme. Article III was written as part of an ELASTINEN (Proactive management of weather and climate related risks) project, funded from the Government's 2015 plan for analysis, assessment and research. Article IV was written as part of the ToPDAd (Tool-supported policy development for regional adaptation) project, funded by the European Commission through the $7^{\text {th }}$ Framework Programme for Research. 


\section{ABBREVIATIONS}

$\mathrm{CO}_{2}$

Carbon dioxide

$\mathrm{CBA}$

Cost Benefit Analysis

CCA

Climate Change Adaptation

DM

Disaster Management

DRM

Disaster Risk Management

DRR

Disaster Risk Reduction

GHG

Greenhouse Gas

IPPC

Intergovernmental Panel on Climate Change

UNDRR

United Nations Office for Disaster Risk Reduction 


\section{INTRODUCTION}

\subsection{Hazards, disasters and climate change}

As witnessed worldwide, hydro-meteorological hazards-such as cyclones, floods, heatwaves and various forms of droughts-have caused major negative socio-economic impacts and consequences throughout history. This situation has been worsening due to a trajectory of socio-economic development and politics, such as population and wealth increases along coasts and lack of investment in reduction and preparedness measures (Barthel and Neumayer, 2012; Klotzbach et al., 2018; Neumayer and Barthel, 2011; Neumayer et al., 2014; Pielke, 2019; The World Bank and the United Nations, 2010), and individual and collective decision-making (Adger et al., 2005; Neumayer et al., 2014) which ignore the risks posed by hydro-meteorological hazards. Climate change is further challenging the situation, emphasising the urgent need to develop and implement governance structures, policies (Amundsen et al., 2010; Bauer et al., 2012; Burton et al., 2002; Corfee-Morlot et al., 2011; Djalante et al., 2013; Urwin and Jordan, 2008) and measures (Carter et al., 1994; Hallegatte, 2009; Smit et al., 2000) that aim at tackling the root causes of disasters and reducing the risk of weather events and climate change (Alexander and Davis, 2012; Eriksen and O'Brien, 2007; Pielke, 2005; Wisner et al., 2003).

Natural hydro-meteorological hazards or weather and climate extremes ${ }^{1}$, pose risks to various assets: ecosystems, the lives and livelihoods of people, communities, infrastructure, cultural heritage, the economy and societies in general (IPCC, 2012). Depending on the scale of the hazard, and particularly the underlying factors, the hazard may escalate to a disaster; "Severe alterations in the normal functioning of a community or a society due to hazardous physical events interacting with vulnerable social conditions, leading to widespread adverse human, material, economic, or environmental effects that require immediate emergency response to satisfy critical human needs and that may require external support for recovery" (IPCC, 2014a;. p.1763). Hazards turn into disasters through complex interactions between underlying socio-economic, political and cultural factors, which largely contribute to the creation of risk caused by extreme events (Alexander and Davis, 2012; Wisner, 2016; Wisner et al., 2003).

Meanwhile, due to various anthropogenic processes (Edenhofer et al., 2014), greenhouse gas $(\mathrm{GHG})$, such as carbon dioxide $\left(\mathrm{CO}_{2}\right)$ and methane $\left(\mathrm{CH}_{4}\right)$, concentrations in the atmosphere have substantially increased. For instance, the $\mathrm{CO}_{2}$ concentration has increased from an estimated $285 \mathrm{ppm}$ (parts per

${ }^{1}$ also called extreme, severe, rare or high-impact weather or flood events (Stephenson, 2008), climate extremes, weather and climate variability (IPCC; 2012) 
million') in $185^{3}$ to $413 \mathrm{ppm}$ in April $2020^{4}$. This is changing the global energy balance and the flow of energy through the climate system; altering the circulation patterns of the atmosphere, modifying the hydrological cycle, rising global sea level and also leading to changing weather and climate extremes $^{5}$ (Stocker et al., 2013). Furthermore, other anthropogenic factors, such as urbanisation (Peng et al., 2012), land use change (e.g. vegetation change) (Cornelissen et al., 2013; Pielke Sr et al., 2011; Pielke Sr, 2005; Swingland. et al., 2002), black carbon (Bond et al., 2013) and aerosol emissions (Rosenfeld et al., 2008) are changing climatological and hydrological patterns at regional and local scales. Amplifiers, creating positive feedback loops, occur naturally in earth systems and may further speed up the consequences of anthropogenic or natural triggers (Alley et al., 2003; Kutzbach et al., 1996). Evidence shows that climate change can already be attributed to the changing probability of individual hydro-meteorological events (Stott et al., 2015; Trenberth et al., 2015; Otto et al., 2018), but the evidence is more unclear whether climate change has contributed to the increasing socio-economic impacts and consequences of climate-related hazards (Barthel and Neumayer, 2012; Changnon et al., 2000; Gleditsch, 2012; IPCC, 2014b, ch. 18; Klotzbach et al., 2018; Neumayer and Barthel, 2011; Pielke Jr, 2019; Sander et al., 2013;).

The atmosphere is a global common pool resource (Dietz et al., 2003; Hanley et al., 1997; Nordhaus, 1982; Ostrom et al., 1999). Most importantly, it possesses the property of non-excludability: consumption of the atmosphere as GHG storage by one does not exclude others from consuming it. As witnessed with many other common pool resources, the atmosphere is subject to the 'tragedy of the commons' (Hardin, 1968; Milinski et al., 2002), i.e., overuse as witnessed by ongoing, anthropogenic climate change. Therefore, as opposed to pure public goods which share both the properties of nonexcludability and non-rivalry (Samuelson, 1954), climate policy with specific GHG reduction targets has turned the atmosphere into a rivalrous good. Thereby, GHG emissions emitted to the atmosphere by an individual, a household, a factory, a firm, a farm, or at the aggregate level of a country exhaust the possibilities of other economic agents to emit without increasing the levels of the atmospheric GHG composition; thus, changing the current balance of the climate system at a pace that humans and ecosystems may not be able to adapt to (Kates et al., 2012; Ramanathan and Feng, 2008; Schellnhuber, 2008; Weitzman, 2011).

To a large extent, global climate change caused by the accumulation of GHGs in the atmosphere is a negative externality. It is predicted to create various, potentially very negative consequences on ecosystems and economic agents

\footnotetext{
${ }^{2}$ dry mole fraction defined as the number of molecules of carbon dioxide divided by the number of molecules of dry air multiplied by one million

3 https://data.giss.nasa.gov/modelforce/ghgases/Fig1A.ext.txt [Accessed 17 May 2020]

$4 \underline{\text { https://climate.nasa.gov/vital-signs/carbon-dioxide/ [Accessed } 17 \text { May 2020] }}$

5 due to the decreasing amount of thermal radiation from land and oceans radiated back to space
} 
(IPCC, 2014b, ch.18). As with any externality (Pigou, 1928), the agents causing climate change, and particularly the negative consequences of climate change, are often not the same agents who bear the consequences (Stern et al., 2006). As noted by Tol (2009, p. 29), "climate change is the mother of all externalities"; it is a complex, highly uncertain and potentially a large societal challenge in which efforts to solve are complicated by various political and technological challenges (e.g. Knutti et al., 2016; Pindyck, 2013; Weitzman, 2011, 2009).

Major global political efforts have been taken to reduce the risks posed by disasters and climate change. The 2005 Hyogo Framework for Action (UNISDR, 2005) and the more recent Sendai Framework for Disaster Risk Reduction (UNISDR, 2015a), adopted in 2015, lay the foundation for global efforts in multi-hazard disaster risk reduction (DRR) and disaster risk management (DRM). The Paris Agreement approved in $\mathrm{COP}^{6} 23$, in 2015, and its ratification by 185 countries (Parties to the United Nations Framework Convention on Climate Change in 1992) is the most recent sign of global political will to tackle the challenge of climate change.

Climate change mitigation, i.e. the reduction of GHG emissions from energy, land use and other sources (Edenhofer et al., 2014), is currently attracting most of the academic and, in particular, political attention. However, in practice, various challenges, such as the lack of political ambition (Rogelj et al., 2016), lack of cooperation and coordination in global climate policy (Harris, 2007; Keohane and Victor, 2016; Nordhaus, 2015; Weitzman, 2015), lack of technologies to reach a required level of GHG emissions (Arvesen et al., 2011; Fuss et al., 2016), individual preferences and behaviour ${ }^{7}$ have maintained an increasing rate of GHG emissions. Therefore, despite the stated political will to halt the increase of GHG emissions since the first climate negotiations (COP1) in 1995, they have been steadily increasing ${ }^{8}$. This has emphasised the urgency and challenges related to policies and measures that aim at reducing the socio-economic impacts of hydro-meteorological events, i.e climate change adaptation (CCA) (Adger et al., 2005; Hallegatte, 2009; Pielke Jr et al., 2007; Smit et al., 2000; Tol, 2005). On the one hand, climate change mitigation and CCA are efforts to tackle the impacts of climate change: mitigation reduces our need for CCA, and vice versa (Kane and Shogren, 2000; Tol, 2005). Academic research has developed models that account for the complementarity of mitigation and CCA for effective management of climate change risk, resulting in an economically optimal mix of mitigation and CCA (see Kane and Shogren, 2000).

On the other hand, to prevent, reduce and prepare for disaster risk and to respond to and recover from disasters associated with natural hazards and

${ }^{6}$ Conference of the Parties

7 https://www.iea.org/newsroom/news/2019/october/growing-preference-for-suvs-challengesemissions-reductions-in-passenger-car-mark.html [Accessed 17 May 2020]

8 https://climate.nasa.gov/vital-signs/carbon-dioxide/ [Accessed 17 May 2020] 
climate change, there are two, often separately addressed fields of research, policy and practice: DRM and CCA (IPCC, 2012, 2014a). DRM and CCA in human systems share the objective of reducing the impacts of weather and climate extremes through focusing on the exposure and vulnerability of people and assets at risk and improving disaster response and recovery. This is done by developing improved and integrated policies and strategies, implementing measures through investing in technological development and innovations, and encouraging the adoption of behavioural change at an individual level (Gero et al., 2011; IPCC, 2012; Mendelsohn, 2012, 2000; Pielke Jr et al., 2007; Tol, 2005) (see Section 2.1 for definitions for DRM and CCA). The benefit of CCA in terms of DRM is that it brings a long-term perspective to the traditional DRM approach (Ireland, 2010; Kelman et al., 2015; Mercer, 2010; Rivera \& Wamsler, 2014; Schipper 2011; Venton \& La Trobe 2008).

Despite the potential to increase the efficiency and effectiveness of DRM and CCA through their integration in research, governance and practice (Venton \& La Trobe 2008), integration is still in its infancy (Ireland, 2010; Kelman et al., 2015; Mercer, 2010; Rivera \& Wamsler, 2014). Challenges behind the lack of integration have been identified (Gero et al., 2011; Mercer, 2010; Rivera \& Wamsler, 2014;), but no precise definition for the relationship between DRM and CCA and their joint integration, or mainstreaming, in other policy fields exist within the integration literature. Furthermore, empirical accounts of DRM and CCA integration are still scarce. Vulnerability reduction is at the core of DRM and CCA, but its realisation is often challenged by low quality governance (UNISDR, 2015b) which is interlinked with other socio-cultural factors (Alexander \& Davis, 2012). The majority of the literature on governance challenges has focused on economically less developed countries, with less analysis on effective governance in wealthier countries. The literature also lacks analysis on the complexity of DRM and CCA governance owing to multiple, competing decision-making criteria: effective implementation of DRM and CCA governance and implementation does not necessarily imply cost-efficiency, resulting in potential over-adaptation to disasters and climate change (Hanemann, 2000). Furthermore, governance and improved DRM and CCA measures do not lessen the importance of the role of decision-making down to the level of the individual in reducing the impacts of natural hazards, disasters and climate change (Adger et al., 2005).

The academic literature has discussed the complexities of DRM for a long time (e.g. White, 1945) and more recently CCA (Adger et al., 2005; 2009; IPCC, 2014b ch.16). In this thesis, I identify and address challenges related to DRM and CCA policies, governance, measures, and their implementation, specifically related to i) DRM and CCA policy integration, ii) the governance of vulnerability reduction and iii) cost-efficiency and effectiveness of DRM and CCA measures. 


\subsection{Research Question and Objectives}

This thesis investigates the following question: what are the means to overcome the salient challenges in DRM and CCA policies and measures that are designed to reduce the risks posed by extreme weather under uncertainty? This question is examined from multiple angles leading to the following research objectives:

- To identify and analyse the challenges related to DRM and CCA integration, and their further integration into sectoral policies, to ensure efficient and effective reduction of extreme weather events and climate change impacts;

- To explore how governance, other socio-cultural structures, policies and their implementation can effectively reduce disaster risk and climate change by using the Nordic welfare state as an example of a success story in DRM and CCA;

- To analyse the efficiency, effectiveness and social acceptability of DRM and CCA measures under future uncertainty.

The thesis contributes to the literature in the following ways. Conceptually, it provides a definition for DRR and CCA integration and their integration to sectorial policies, and an economic definition for over-adaptation to climate change. Empirically, it contributes to i) the scarce literature on the challenges of policy-level DRM and CCA integration and their integration into sectoral policies, ii) the literature on how DRM and CCA approaches are implemented in Finland and whether current vulnerability and exposure assessments neglect some risks or hinder the seizing of opportunities brought by climate change; and iii) the empirical economic literature on DRM and CCA measures under uncertainty.

\subsection{Approach}

The research question and objectives are addressed in four articles which analyse DRM and CCA governance and measures from economic and policy perspectives, yet cover different empirical foci, methods, data and geographical scopes. Table 1 shows the data and methods used in the articles and how risk and uncertainty are addressed for DRM and CCA. 


\begin{tabular}{|c|c|c|c|c|}
\hline PAPER & DATA & METHODS & $\begin{array}{l}\text { RISK AND } \\
\text { UNCERTAINTY }\end{array}$ & DRM \& CCA \\
\hline I & $\begin{array}{l}\text { Interviews } \\
\text { and policy } \\
\text { documents }\end{array}$ & $\begin{array}{l}\text { Coding of } \\
\text { qualitative } \\
\text { data }\end{array}$ & $\begin{array}{l}\text { Risk from natural hazards } \\
\text { and climate change; } \\
\text { uncertainty due to climate } \\
\text { change }\end{array}$ & $\begin{array}{l}\text { Policy integration for } \\
\text { effective and efficient } \\
\text { DRM and CCA }\end{array}$ \\
\hline II & $\begin{array}{l}\text { Interviews } \\
\text { and policy } \\
\text { documents }\end{array}$ & $\begin{array}{l}\text { Exploratory } \\
\text { case study }\end{array}$ & $\begin{array}{l}\text { Risk from natural hazards } \\
\text { and climate change; } \\
\text { uncertainty not formally } \\
\text { analysed }\end{array}$ & $\begin{array}{l}\text { DRM and CCA policy } \\
\text { analysis }\end{array}$ \\
\hline III & $\begin{array}{l}\text { Quantitative } \\
\text { data }\end{array}$ & $\begin{array}{l}\text { Cost-benefit } \\
\text { Analysis; } \\
\text { Monte Carlo } \\
\text { Analysis }\end{array}$ & $\begin{array}{l}\text { Storm risk on electricity } \\
\text { network; uncertainty in } \\
\text { parameter values due to } \\
\text { future uncertainty }\end{array}$ & $\begin{array}{l}\text { Cost efficiency of an } \\
\text { integrated DRM and } \\
\text { CCA measure }\end{array}$ \\
\hline IV & $\begin{array}{l}\text { Interviews } \\
\text { and } \\
\text { literature }\end{array}$ & $\begin{array}{l}\text { Interview } \\
\text { coding and } \\
\text { quantitative } \\
\text { calculation of } \\
\text { monetary } \\
\text { benefits; } \\
\text { sensitivity } \\
\text { analysis }\end{array}$ & $\begin{array}{l}\text { Risk of changing weather } \\
\text { conditions; } \\
\text { uncertainty of climate } \\
\text { change impacts }\end{array}$ & $\begin{array}{l}\text { Economic benefits of a } \\
\text { CCA measure }\end{array}$ \\
\hline
\end{tabular}

Article I addresses the level of DRM and CCA policy integration as a means for the effective and efficient management of weather and climate change related risks in Zambia. It focuses on DRM and CCA capacities; the status of DRM and CCA policy integration and the level of budget allocation for DRM and CCA. Uncertainty is not explicitly analysed, but the article is framed to address the increasing uncertainty of natural hazards due to climate change. The situation regarding the level of integration is analysed at horizontal (inter-ministerial) and vertical (intra-ministerial) dimensions, leading to an assessment of the challenges regarding effective integration. Article II discusses the contribution of the underlying risk drivers of governance, societal and political factors, culture, policies and their implementation to DRM and CCA. The article describes the Finnish model, the role of governance and society for DRM and CCA and assesses how the model, or more broadly the Nordic Welfare state model, can effectively reduce vulnerability to natural hazards. Article III furthers the analysis of the Finnish approach to DRM and CCA through a social in medias res/ex-post cost benefit analysis on the Finnish Electricity Market Act 2013 (Sähkömarkkinalaki 588/2013, 2013), which defines strict limitations to, mostly, storm and snow induced power outages and has therefore contributed to major investments in weather-proofing the electricity distribution network, partly aiming at effective reduction of weather-induced impacts. Furthermore, Article III describes the public response to the Act. Risk and uncertainty are key concepts of Article IV as uncertain changing climate will pose new risks to the road transport sector. Due to the uncertainty, robust methods are needed to reduce the risk in the changing conditions. Uncertainty 
is addressed through sensitivity analysis. Article IV has been framed from CCA perspective, but improved weather services will reduce the risk of weather also in the current climate, thereby contributing also to the improved reduction of extreme weather event impacts in the current climate.

The articles apply both qualitative and quantitative methods to analyse the research question, elaborated in section 3. Mixed methods research is an approach which uses both quantitative and qualitative approaches to seek answers to the research question of interest (Johnson and Onwuegbuzie, 2004) (See section 3.1 for more detail). Qualitative methods are used because of the need to understand how policies are situated and embedded in their implementation context, to identify how contextual factors influence policy processes (Sadovnik, 2007) and to efficiently obtain explicit and tacit knowledge from experts. Quantitative policy analysis with economic methods is used because of the need to address efficiency, cost-effectiveness and the economic benefits of DRM and CCA measures at public and individual decision-making levels (Konrad and Thum, 2014).

Articles I and II are examples of studies using purely qualitative data and analysed with qualitative methods, described in more detail in section 3.2. In Article I, the data consists of interviews and policy documents used to analyse the integration of DRM and CCA policies in Zambia. In Article II data was collected through an online survey, semi-structured interviews and workshops in two research projects which was used to analyse weather and climate related risks in Finland. Both articles analyse the data qualitatively; Article I uses a systematic qualitative method described in section 3.2, whereas Article II uses an explorative method (Baxter and Jack, 2008; Stebbins, 2001) and aims to contribute to the literature by constructing a fresh viewpoint and discussing its implications. Article III uses quantitative data and analyses it with quantitative methods, described in more detail in section 3.3. Article IV combines qualitative and quantitative approaches. Qualitative interviews and document data has been converted into a quantitative assessment on the potential economic benefits of innovations in weather service provision in the road transport sector. 


\section{THEORETICAL BACKGROUND ON DISASTER AND CLIMATE RISK MANAGEMENT UNDER UNCERTAINTY}

\subsection{Disaster Risk Management and Climate Change Adaptation - Policies and Implementation}

Disaster Risk Management (DRM) related to hydro-meteorological events and Climate Change Adaptation (CCA) aim at i) reducing people's and societies' vulnerabilities and exposure to the impacts of natural hazards and ii) increasing their capacity to reduce the risk and prepare for, respond to and recover from disasters. Broadly speaking, both fields share the objective of reducing the human impacts of weather and climate extremes by addressing exposure, underlying vulnerability and enhancing the resilience of affected people and assets (Schipper 2009; Rivera \& Wamsler, 2014; Gero et al., 2011, IPCC, 2012; Kelman et al., 2015). Policies, strategies and measures to decrease exposure and vulnerability and increase capacity are at the core of DRM and CCA (IPCC, 2012). Typically, DRM and CCA are addressed, studied and analysed separately (Ireland, 2010; Kelman et al., 2015; O’Brien et al., 2006), despite their multiple overlaps and synergies (Mercer, 2010; O'Brien et al., 2006; Solecki et al., 2011).

In the field of disaster and CCA studies, four key terms are relevant: Disaster Risk Reduction (DRR), Disaster Management (DM), DRM and CCA. The definitions of these terms by the two key United Nations organisations, the Intergovernmental Panel on Climate Change (the IPCC) and the United Nations Office for Disaster Risk Reduction' (UNDRR), are given in Table 2. The definitions are ambiguous, differing and overlapping on two levels: the scope and object. As per the scope, both the IPCC (2014a) and UNDRR agree on DRR being defined in terms of a policy objective but differ as the IPCC includes strategic and instrumental measures (the object) in DRR. As per the scope, the main difference is in the definition for DRM, as the UNDRR ${ }^{10}$ defines DRM's scope to be the same as DRR's scope: to "prevent new disaster risk, reduce existing disaster risk and manage residual risk", whereas the IPCC (2014) defines DRM to "improve the understanding of disaster risk, foster disaster risk reduction and transfer, and promote continuous improvement in disaster preparedness, response, and recovery practices".

\footnotetext{
9 Formerly the UNISDR; the dedicated UN secretariat to facilitate the implementation of the International Strategy for Disaster Reduction (ISRD)

10 https://www.undrr.org/terminology [Accessed 17 May 2020]
} 
Table 2 The IPCC (2014a) and UNDRR glossary definitions for key terms

\begin{tabular}{|c|c|c|}
\hline & $\begin{array}{c}\text { IPCC } 2014 \text { Glossary (IPCC, } \\
\text { 2014a) }\end{array}$ & $\begin{array}{l}\text { UNDRR Definition \& Annotation } \\
\text { (UNDRR glossary'1) }\end{array}$ \\
\hline $\begin{array}{l}\text { Disaster Risk } \\
\text { Reduction } \\
\text { (DRR) }\end{array}$ & $\begin{array}{l}\text { "Denotes both a policy goal or } \\
\text { objective, and the strategic and } \\
\text { instrumental measures employed for } \\
\text { anticipating future disaster risk; } \\
\text { reducing existing exposure, hazard, or } \\
\text { vulnerability; and improving } \\
\text { resilience." }\end{array}$ & $\begin{array}{l}\text { "[...] is aimed at preventing new and } \\
\text { reducing existing disaster risk and } \\
\text { managing residual risk, all of which } \\
\text { contribute to strengthening resilience and } \\
\text { therefore to the achievement of } \\
\text { sustainable } \\
\text { "[evelopment." } \\
\text { ma... is the policy objective of disaster risk } \\
\text { are defined in disaster risk reduction } \\
\text { strategies and plans." }\end{array}$ \\
\hline $\begin{array}{l}\text { Disaster } \\
\text { Management } \\
(\mathrm{DM})\end{array}$ & $\begin{array}{l}\text { "Social processes for designing, } \\
\text { implementing, and evaluating } \\
\text { strategies, policies, and measures } \\
\text { that promote and improve disaster } \\
\text { preparedness, response, and recovery } \\
\text { practices at different } \\
\text { organizational and societal levels." }\end{array}$ & $\begin{array}{l}\text { "The organization, planning and } \\
\text { application of measures preparing for, } \\
\text { responding to and recovering from } \\
\text { disasters." } \\
\text { "[...] may not completely avert or } \\
\text { eliminate the threats; it focuses on } \\
\text { creating and implementing preparedness } \\
\text { and other plans to decrease the impact of } \\
\text { disasters and "build back better". Failure } \\
\text { to create and apply a plan could lead to } \\
\text { damage to life, assets and lost revenue." }\end{array}$ \\
\hline $\begin{array}{l}\text { Disaster Risk } \\
\text { Management } \\
\text { (DRM) }\end{array}$ & $\begin{array}{l}\text { "Processes for designing, } \\
\text { implementing, and evaluating } \\
\text { strategies, policies, and measures to } \\
\text { improve the understanding of disaster } \\
\text { risk, foster disaster risk reduction } \\
\text { and transfer, and promote continuous } \\
\text { improvement in disaster preparedness, } \\
\text { response, and recovery practices, with } \\
\text { the explicit purpose of increasing } \\
\text { human security, well-being, quality of } \\
\text { life, and sustainable development." }\end{array}$ & $\begin{array}{l}\text { "[...] is the application of disaster risk } \\
\text { reduction policies and strategies to prevent } \\
\text { new disaster risk, reduce existing disaster } \\
\text { risk and manage residual risk, } \\
\text { contributing to the strengthening of } \\
\text { resilience and reduction of disaster losses." } \\
\text { "[...] actions can be distinguished between } \\
\text { prospective disaster risk management, } \\
\text { corrective disaster risk management and } \\
\text { compensatory disaster risk management, } \\
\text { also called residual risk management." }\end{array}$ \\
\hline $\begin{array}{l}\text { Climate } \\
\text { Change } \\
\text { Adaptation } \\
\text { (CCA) }\end{array}$ & $\begin{array}{l}\text { "The process of adjustment to actual or } \\
\text { expected climate and its effects. In } \\
\text { human systems, adaptation seeks to } \\
\text { moderate or avoid harm or exploit } \\
\text { beneficial opportunities." }\end{array}$ & Not provided \\
\hline
\end{tabular}

This thesis follows the IPCC (2014a) definitions, because the three components of DRM, DRR, DM are clearly defined and the IPCC (2014a) also includes a definition for CCA. DRM is an umbrella term to encompass the entire spectrum from DRR to DM. DRR places focus on anticipating future disaster risk and reducing existing risks through a set of policies, objectives and measures developed and implemented before the disaster occurs by mitigating and reducing hazard, exposure and vulnerability. DM places focus on preparing, responding to and recovering from disasters in the phase when the threat of disaster becomes evident. However, the distinction is ambiguous as in some cases, DRR and DM overlap. For instance, the concept of 'Build

${ }^{11}$ https://www.undrr.org/terminology [Accessed 17 May 2020] 
Back Better' aims at reducing the risk of future disasters (DRR according to IPCC, 2014a) during the post-disaster recovery phase (DM according to IPCC, 2014a) (Mannakkara \& Wilkinson 2015; Wisner 2017; Dube 2020). Noteworthy is that the IPCC (2014a) DRM definition is more explicit on how to reduce risk than the CCA definition, whereas CCA also includes the potential benefits gained from climate change. As implied in the IPCC's DRM definition, it constitutes actions taken at various spatial scales from international agreements to decision-making at an individual level. Although not explicitly stated in the CCA definition, the same applies for CCA as well (e.g. Adger et al., 2005).

At the policy level, the importance of integrating, or mainstreaming CCA policy goals across all relevant policy domains and strategies has been highlighted by researchers (Bauer et al., 2012; Ogallo, 2010; Urwin and Jordan, 2008) and policy-makers, for instance, in the European Union (COM, 2013). The integration of DRM policy goals has not received similar attention in academia, although the role of social protection and other relevant vulnerability reduction policies has been shown to reduce vulnerability to various weather-induced impacts (Devereux, 2016). Policy integration has its roots in Environmental Policy Integration (Jordan and Lenschow, 2010; Mickwitz and Kivimaa, 2007; Nilsson and Persson, 2003; Nunan et al., 2012; Oberthür, 2009), where integration has been widely recognised as an important approach to promote environmental concerns in policy making. Climate Policy Integration (CPI) has traditionally referred to integrating climate change mitigation goals in relevant sectorial policies and strategies (Adelle and Russel, 2013; Dupont and Oberthür, 2012; Ishii and Langhelle, 2011), but as noted, CCA integration, or mainstreaming, has also gained attention.

Measures to reduce the impacts of disasters and climate change have been, for the most part, categorised from a CCA perspective. Various, partly overlapping typologies for CCA in human systems exist. For instance, Konrad and Thum (2014) provide a categorisation of CCA measures based on economic principles; Hallegatte (2009) bases his categorisation on economic rationale in the face of uncertainty regarding climate change. Carmin and Dodman (2013) categorise CCA measures into three types: i) structural/concrete, ii) institutional and iii) social. Furthermore, CCA can be either incremental, if the system is changed by merely extending the current practices, or transformational, if adaptation entails far reaching systemic changes (Kates et al., 2012; see O'Brien, 2012 for a thorough description on deliberate transformation ). Smit et al. (2000) propose a simple definition for CCA by assessing three questions: i) Adaptation to what, ii) Who or what adapts and iii) How does Adaptation occur. In principle, an extension of these three questions is useful for categorising the various typologies of CCA measures. 
The majority of the typologies answer the question "which types of strategies or measures are available" (Biagini et al., 2014; Carmin and Dodman, 2013; Hallegatte, 2009; IPCC, 2012). The typology by Konrad and Thum (2014) is a hybrid; it categorises CCA measures based on the most common question "which types of strategies or measures are available" but also on "Who (or what) adapts and Who (or what) benefits" (also Mendelsohn, 2000; Smit et al., 2000 and empirically in Fidelman et al. (2013)) and "when does adaptation take place" (Fankhauser et al., 1999) (also Carter et al., 1994 and Smit et al., 2000). Lastly, incremental vs transformative typologies respond to "what is the degree of change required?" Although the academic articles providing typologies for CCA measures have all been framed from a CCA perspective, the measures used as examples are all also DRM measures, implying that they would also yield benefits in the current climate. Therefore, it is beneficial from efficiency and effectiveness perspectives to ensure that the policy measures used to reduce the current risks of extreme weather events fulfil the criteria of robustness in the face of deep uncertainty related to climate change and socio-economic factors (Hallegatte, 2009; Hallegatte et al., 2012; Kelman, 2017; Kelman et al., 2015; Mercer, 2010; Schipper, 2009).

\subsection{Risk and Uncertainty}

Risk and uncertainty are some of the defining factors of our existence: they shape our thinking, decision-making and behaviour. Risk and uncertainty have motivated academics to develop theories (e.g. Expected utility theorem (von Neumann and Morgenstern, 1944), Portfolio theory (Markowitz, 1952), Prospect theory (Kahneman and Tversky, 1979), Risk society (Beck, 1992) and the Black Swan theory (Taleb, 2007)) and industry to create an entire industrial sector: finance and particularly the insurance sectors. Disaster and climate change risk have inspired writers (e.g. Science in the Capital trilogy'12 by Kim Stanley Robinson) and film makers (e.g. The Day After Tomorrow by (Emmerich, 2004) and Geostorm (Najafi, 2017)). Inherently, risk and uncertainty are something that we constantly deal with and the way we deal with it depends on our preferences (Arrow, 1971; Pratt, 1964) and intuition (Kahneman \& Tversky, 1979).

\subsubsection{Probabilistic Risk Analysis}

Depending on the research field, risk and uncertainty are often defined and treated in different ways. In neoclassical economics, the distinction between risk and uncertainty is vague, yet based on a strictly probabilistic treatment of uncertainty (Mas-Colell et al., 1995, ch.6). In principle, a risky situation is a decision situation which involves some, specified level of uncertainty. Expected utility theorem (von Neumann and Morgenstern, 1944) and subjective probability theory (Savage, 1954) are both based on the idea that modelling decisions involving an element of risk starts from the notion that in an uncertain environment the decision-maker holds two types of information:

${ }^{12}$ Forty Signs of Rain (2004); Fifty Degrees Below (2005); Sixty Days and Counting (2007) 
i) all possible, uncertain outcomes of the decision made under uncertainty, and ii) a vector of probabilities for each possible outcome; where $p_{s} \geq 0$ are the probabilities of occurrence of $x_{s}$ with $\sum_{s=1}^{S} p_{s}=1$. (Gollier, 2001, p. 4).

Expected utility theorem assumes that the vector of probabilities for each possible outcome can be summarized by means of objective numerical probabilities by the decision-maker. If we let $A=\left\{a 1, \ldots a_{N}\right\}$ be the set of all possible outcomes which involve some source of uncertainty and $p_{i} \geq 0$, where $p_{i}$ represents the uncertainty as the probability of outcome $a_{i}$ occurring, a simple lottery is a list $L=\left(p_{1}, \ldots, p_{N}\right)$ with $p_{n} \geq 0$ for all $A$. Simply put, the set of simple lotteries is given by the probability of each outcome multiplied by the outcomes in question. (Mas-Colell et al., 1995) The main purpose of expected utility theorem is to assess choice under uncertainty assuming certain decision-maker preferences over the uncertain outcomes.

In subjective probability theory, the assumption on objectively known probabilities is relaxed to incorporate the fact that the reality is hardly ever based on objectively known probabilities. In subjective probability theory, individuals hold beliefs over the likelihood of various outcomes and through choices reveal these beliefs in a well-defined probabilistic manner. Thereby, subjective probability theory can be considered a "far-reaching generalisation of expected utility theory”. (Mas-Colell et al., 1995, p. 205).

Risk is most commonly defined as the probability of an adverse event (e.g. a natural hazard) times its consequences:

$R=p_{i} C i V c$,

where $i$ is a certain event; $C$ is the expected outcome of the event; and in case of economic damage, $V$ is the economic value of the outcome. (Renn, 1998; Rosa, 1998). Hydro-meteorological processes are often used as an example of risk and uncertainty in literature on decision-making under risk. Typically, historical hydro-meteorological events can be expressed in probabilities (e.g. return periods which express the likelihood of an event happening in a certain time period) (e.g. Kunkel et al., 1999b, 1999a) and are therefore a convenient expression of risk for decision-making science. For instance, a decision-maker may face an investment decision for a dam when they know that the yearly probability for wet and dry years is 0.3 and 0.7, respectively (Graham, 1981). These probabilities are usually derived from historical observations and, in the best case, can be considered relatively objective.

This definition, however, does not explicitly address the underlying risk drivers: exposure, vulnerability and capacity, even though implicitly incorporated in $\mathrm{p}_{\mathrm{i}}$ and $\mathrm{C}_{\mathrm{i}}$ (IPCC; 2012). Explicit treatment of the underlying risk drivers is crucial for the development of DRM and CCA policies and measures. As noted by Wisner et al. (2003, p. 4), disasters are "the product of social, political and economic environments because of the way these structure the lives of different groups of people". This has led to the use of the following 
extended frameworks of traditional probabilistic risk analysis in DRM and CCA fields.

\subsubsection{Extensions of the probabilistic risk analysis}

Two widely adopted, partly overlapping theoretical frameworks which are the most relevant for this thesis are the IPPC (2014) and UNDRR risk frameworks, the Pressure-and-Release Model (PAR) and, its extension, the Access model (Wisner et al., 2003). All these focus, to a varying degree, on the underlying risk drivers behind natural hazards and climate change.

The IPCC (2014) framework, adopted by the IPPC in 2012 (IPCC; 2012), is used by the United Nations Global Risk Data Platform ${ }^{13}$-also widely in climate risk assessments (UNISDR, 2017) - and defines risk as being a function of hazard, exposure and vulnerability. The UNDRR ${ }^{14}$ also includes capacity. In the IPCC (2014) framework, hazard is a hydro-meteorological event or gradual climate change and is typically described by the (joint) statistical distribution of various climatological parameters (IPCC, 2012; Katz and Brown, 1992). Climate is defined as the "the statistical description in terms of the mean and variability of relevant quantities over a period of time ranging from months to thousands or millions of years" and as "the state, including a statistical description, of the climate system" (IPCC, 2014a, p. 1760). Climate describes the statistical properties of various surface weather parameters, over a certain period, usually 30 years (World Meteorological Organization, 2008). Climate change refers to changes in the statistical properties of the climate parameters, in the mean and/or in the variability of the statistical properties of the climate (IPCC, 2014a). There is no precise statistical definition for an extreme event, as a probabilistically extreme hydro-meteorological hazard may not cause extreme socio-economic impacts, and the definition of extreme depends on temporal and spatial scales (e.g. IPCC, 2012, p. 117; Stephenson, 2008).

The remaining components in the risk equation are constructions of socioeconomic, cultural, political and other anthropogenic processes. Table 3 shows the IPCC (2014a) and UNDRR definitions for the key risk components. Noteworthy is that the IPCC (2014a) definitions have changed since the Managing the Risks of Extreme Events and Disasters to advance Climate Change Adaptation report (IPCC, 2012), where the definitions were closer to the UNDRR definitions.

13 https://preview.grid.unep.ch/[Accessed 17 May 2020]

14 https://www.undrr.org/terminology [Accessed 17 May 2020] 
Table 3. The IPCC (2014a) and UNDRR definitions for Risk, Exposure, Vulnerability and Capacity

\begin{tabular}{|c|c|c|c|c|}
\hline & \multicolumn{2}{|l|}{ IPCC $2014 a$} & \multicolumn{2}{|c|}{$\begin{array}{l}\text { UNDRR Definition \& } \\
\text { Annotation }\end{array}$} \\
\hline $\begin{array}{l}\text { (Disaster) } \\
\text { Risk }\end{array}$ & \multicolumn{2}{|c|}{$\begin{array}{l}\text { "The potential for consequences } \\
\text { where something of value is at } \\
\text { stake and where the outcome is } \\
\text { uncertain, recognizing the } \\
\text { diversity of values. [...] } \\
\text { Risk results from the interaction } \\
\text { of vulnerability, exposure, and } \\
\text { hazard. In this report, the term } \\
\text { risk is used primarily to refer to } \\
\text { the risks of climate-change } \\
\text { impacts." }\end{array}$} & \multicolumn{2}{|c|}{$\begin{array}{l}\text { "The potential loss of life, injury, or } \\
\text { destroyed or damaged assets which could } \\
\text { occur to a system, society or a community in } \\
\text { a specific period of time, determined } \\
\text { probabilistically as a function of hazard, } \\
\text { exposure, vulnerability and capacity." }\end{array}$} \\
\hline Exposure & \multicolumn{2}{|c|}{$\begin{array}{l}\text { "The presence of people, } \\
\text { livelihoods, species or } \\
\text { ecosystems, environmental } \\
\text { functions, services, and } \\
\text { resources, infrastructure, or } \\
\text { economic, social, or cultural } \\
\text { assets in places and settings that } \\
\text { could be adversely affected." }\end{array}$} & \multicolumn{2}{|c|}{$\begin{array}{l}\text { "The situation of people, infrastructure, } \\
\text { housing, production capacities and other } \\
\text { tangible human assets located in hazard- } \\
\text { prone areas." }\end{array}$} \\
\hline Vulnerability & \multicolumn{2}{|c|}{$\begin{array}{l}\text { "The propensity or predisposition } \\
\text { to be adversely affected. } \\
\text { Vulnerability encompasses a } \\
\text { variety of concepts and elements } \\
\text { including sensitivity or } \\
\text { susceptibility to harm and lack of } \\
\text { capacity to cope and adapt. " }\end{array}$} & \multicolumn{2}{|c|}{$\begin{array}{l}\text { "The conditions determined by physical, } \\
\text { social, economic and environmental factors } \\
\text { or processes which increase the } \\
\text { susceptibility of an individual, a community, } \\
\text { assets or systems to the impacts of hazards." } \\
\text { "Annotation: For positive factors which } \\
\text { increase the ability of people to cope with } \\
\text { hazards, see also the definitions of } \\
\text { "Capacity" and "Coping capacity"" }\end{array}$} \\
\hline Capacity & $\begin{array}{l}\text { Adaptive } \\
\text { capacity } \\
\text { "The ability of } \\
\text { systems, } \\
\text { institutions, } \\
\text { humans, and } \\
\text { other organ- } \\
\text { isms to adjust } \\
\text { to potential } \\
\text { damage, to } \\
\text { take advantage } \\
\text { of opport- } \\
\text { unities, or to } \\
\text { respond to } \\
\text { consequences" }\end{array}$ & $\begin{array}{l}\text { Coping } \\
\text { capacity: } \\
\text { "The ability of } \\
\text { people, } \\
\text { institutions, } \\
\text { organizations, } \\
\text { and systems, } \\
\text { using available } \\
\text { skills, values, } \\
\text { beliefs, } \\
\text { resources, and } \\
\text { opportunities, } \\
\text { to address, } \\
\text { manage, and } \\
\text { overcome } \\
\text { adverse } \\
\text { conditions in } \\
\text { the short to } \\
\text { medium term." }\end{array}$ & $\begin{array}{l}\text { Capacity } \\
\text { "The combination } \\
\text { of all the } \\
\text { strengths, } \\
\text { attributes and } \\
\text { resources } \\
\text { available within } \\
\text { an organization, } \\
\text { community or } \\
\text { society to manage } \\
\text { and reduce } \\
\text { disaster risks and } \\
\text { strengthen } \\
\text { resilience." }\end{array}$ & $\begin{array}{l}\text { Coping capacity } \\
\text { "The ability of people, } \\
\text { organizations and } \\
\text { systems, using } \\
\text { available skills and } \\
\text { resources, to manage } \\
\text { adverse conditions, risk } \\
\text { or disasters. The } \\
\text { capacity to cope } \\
\text { requires continuing } \\
\text { awareness, resources } \\
\text { and good management, } \\
\text { both in normal times as } \\
\text { well as during disasters } \\
\text { or adverse conditions. } \\
\text { Coping capacities } \\
\text { contribute to the } \\
\text { reduction of disaster } \\
\text { risks." }\end{array}$ \\
\hline
\end{tabular}


In principle, the IPCC (2014a) and the UNDRR agree on the concept of exposure: it refers to people and assets being located in places, such as coastal areas, small islands or urban areas, where a hazard may occur. Vulnerability, however, is an ambiguous concept and the challenges related to defining and empirically assessing vulnerability have been discussed in detail in literature (Bogardi, 2006; Wisner, 2016). The IPCC (2014a) definition for vulnerability highlights this ambiguity, because it does not define, as opposed to the UNDRR (also in IPCC; 2012), any attributes/factors/conditions which contribute to people and societies being vulnerable to natural hazards and climate change (Wisner, 2016). Nevertheless, exposure is a necessary, yet not a sufficient, condition for disaster risk as it is possible to be exposed to a hazard but to have sufficient means to reduce vulnerability to a level where impacts are not experienced (IPCC, 2012).

The main difference between the IPCC (2014a) and UNDRR definitions for risk is the capacity component. Indeed, it may be argued that capacity is just another side of the vulnerability coin and the inclusion does not provide any added value to the definition. However, as explained in Wisner et al (2003), the situation is more nuanced: vulnerable people and communities have capacities that are not captured if the focus is only on vulnerability. This also applies at larger scales; e.g. communities and countries. Therefore, capacity, as a separate analytical component, increases our understanding of the complex notion of risk.

Various mathematical formulations for the definition of risk exist. Peduzzi et al. (2009) assume that risk follows a multiplicative formula as follows:

$R=H_{f r} \times P o p \times V u l$

where: $\mathrm{R}=$ number of expected human impacts [killed/year]. $\mathrm{H}_{\mathrm{fr}}=$ frequency of a given hazard [event/year]. Pop = population living in a given exposed area [exposed population/event]. Vul = vulnerability depending on socio-politicoeconomical context of this population [non-dimensional number between $\mathrm{o}-$ 1]. The formula shows that if any of the factors $\mathrm{H}_{\mathrm{fr}}, \mathrm{Pop}, \mathrm{Vul}=0$, then the risk is null. This formulation of the risk focuses solely on the risk of human casualties. A generalised form is given in e.g. Carrão et al. (2016):

$R=$ Hazard $x$ Exposure $x$ Vulnerability

where all the three components are normalised to $[0,1]$. Noteworthy is that the mathematical notions in the literature neither include capacity a risk component, nor do they explicitly include the notion that the risk components are a function of time, $t$, and space, $s$. Therefore, a generalised representation of eq [1] is as follows:

$R=f\left(\right.$ hazard $_{s, t,}$, exposure $_{s, t}$, vulnerability $_{s, t}$, capacity $\left._{s, t}\right)$, 
where $\mathrm{R}$ denotes risk.

The second, the PAR model, widely used in the disaster field goes deeper in the societal processes and root causes which put people in vulnerable positions. It defines disaster risk as Risk = Hazard x Vulnerability; a definition used also by the IPCC before 2012. Vulnerability is decomposed to three parts: i) root causes, ii) dynamic pressures and iii) unsafe conditions. It includes the exposure and capacity factors from the IPCC (2012) framework as part of vulnerability. All the risk components are functions of time and space (Cutter and Finch, 2000; Wisner et al., 2003). and the PAR model, even though not mathematically defined as functions, analyses the different components implicitly as functions of time and space. The extension of the PAR, the Access model, provides a more detailed analysis of the economic, social and political processes that create vulnerability to hazards. The main addition to the IPCC (2014a) and the UNDRR vulnerability definition is the inclusion of political processes as an important vulnerability factor (See also Wisner, 2016). Hazard is defined similar to the IPCC framework in a probabilistic way (Wisner et al., 2003).

\subsubsection{Uncertainty}

Various definitions for uncertainty exist. Relevant for this thesis is the distinction between two forms of uncertainty: measurable and unmeasurable. Measurable uncertainty can be expressed, one way or another, in a probabilistic form and was introduced in section 2.2.1. The idea being that uncertainty-and the subjective uncertainty regarding the uncertainty-can be measured is visible for instance in the latest IPCC uncertainty definition. It expresses uncertainty as something that can be quantitatively measured or qualitatively assessed:

"A state of incomplete knowledge that can result from a lack of information or from disagreement about what is known or even knowable. It may have many types of sources, from imprecision in the data to ambiguously defined concepts or terminology, or uncertain projections of human behaviour. Uncertainty can therefore be represented by quantitative measures (e.g., a probability density function) or by qualitative statements (e.g., reflecting the judgment of a team of experts)" (IPCC; 2014a, p. 1774).

However, the notion of uncertainty with objectively or subjectively known or estimated probability distributions and subjective confidence intervals, including clear definitions for complex socio-cultural and political factors and processes as defined by the IPCC, ignores the multitude of challenges related to disaster and climate change risk assessments.

The distinction between measurable and unmeasurable uncertainty was first formally suggested by Knight (1921). He notes that 
“...Uncertainty must be taken in a sense radically distinct from the familiar notion of Risk [...]. The essential fact is that "risk" means in some cases a quantity susceptible of measurement, while at other times it is something distinctly not of this character; and there are farreaching and crucial differences in the bearings of the phenomenon depending on which of the two is really present and operating. There are other ambiguities in the term "risk" as well [...]; but this is the most important. It will appear that a measurable uncertainty, or "risk" proper, as we shall use the term, is so far different from an unmeasurable one that it is not in effect an uncertainty at all."

In climate change literature, the unmeasurable uncertainty, so called Knightian uncertainty, is increasingly called deep uncertainty (Hallegatte et al., 2012; Lempert, 2014).

Walker et al (2010, p. 918) describes a categorisation of four levels of uncertainty between the two extremes of determinism, where everything is precisely known and total ignorance where nothing is known about the future:

"Level 1 uncertainty is any uncertainty that can be described adequately in statistical terms; Level 2 uncertainty implies that there are alternative, trend-based futures and/or different parameterizations of the system model, and some estimate can be made of the probability of each of them; Level 3 uncertainty represents deep uncertainty about the mechanisms and functional relationships being studied; Level 4 uncertainty implies the deepest level of recognized uncertainty; in this case, we only know that we do not know";

Levels 1 and 2 are measurable uncertainties, or risk, according to Knight (1921), and levels 3 and 4 constitute unmeasurable uncertainties. Level 4 uncertainties are also called Black Swan events (Taleb, 2007). Level 3 uncertainty, deep uncertainty, is defined as a situation when "analysts do not know, or the parties to a decision cannot agree on, (1) the appropriate models to describe the interactions among a system's variables, (2) the probability distributions to represent uncertainty about key variables and parameters in the models, and/or (3) how to value the desirability of alternative outcomes" (Lempert et al., 2003, p. 3).

In the disaster and climate change field the following uncertainties are relevant, for instance: i) the current probability distributions of (joint) hydrometeorological variables to adequately define the hazard probability (Highfield et al., 2013; Morss et al., 2005), ii) parameter values in the changing climate (Morss et al., 2005), iii) analysis of vulnerability and capacity (Wisner, 2016); iv) climate model uncertainties (van Asselt and Rotmans, 2002); v) challenges related to the assessment of the socio-economic impacts of climate change (Thorarinsdottir et al., 2017), vi) evolving societal factors (Morss et al., 2005; van Asselt and Rotmans, 2002); vii) scientific uncertainty due to 
"complexity, stochasticity, or a fundamental lack of data or understanding" (Morss et al., 2005, p. 1596); and viii) the practical constraints in using uncertain information in policy and decision-making (Morss et al., 2005). Therefore, a probabilistic definition of risk and uncertainty does not capture true, unmeasurable uncertainty which is crucial when we discuss future climate change and adaptation to its impacts (Konrad and Thum, 2014).

For instance, Thorarinsdottir et al. (2017) quantify uncertainty related to sea level rise and associated economic damage for CCA decision-making and conclude that not accounting for uncertainties in climate change impact studies may result in 'bad scenarios' that result in the situation being an order of magnitude worse than what the decision-maker might expect if uncertainty is not accounted for. The analysis is based on several assumptions and simplifications, and shows how difficult, and perhaps impossible, it is to provide a reliable assessment of the socio-economic impacts of climate change.

\subsection{Efficiency and Effectiveness}

Defining 'successful' DRM and CCA is not an easy task (Adger et al., 2005; Baker et al., 2012; de Bruin et al., 2009). Adger et al. (2005) argue that the four criteria of effectiveness, efficiency, equity and legitimacy of CCA are important in the analysis of success. They note that the criteria are contested, context-specific and based on competing values.

Economists tend to emphasise efficiency and effectiveness as key criteria in public sector decision-making regarding DRM and CCA (Konrad and Thum, 2014; Mendelsohn, 2000; The World Bank and the United Nations, 2010). Effectiveness of DRM and CCA measures implies that a certain outcome or objectives regarding the reduction of disaster and climate change impacts are achieved. More precisely, cost-effectiveness implies that the outcome or objectives are achieved in the least-cost way. Cost efficiency of CCA is broadly defined as CCA which maximizes net benefits.

Formally, efficient CCA at the private and societal level has been defined in Mendelsohn (2012). Private CCA is a decision taken by an individual that only affects that individual; the costs and benefits of the decision only accrue to the individual. If we assume that strict assumptions on market access, private property rights, lack of externalities and good information hold, individuals choose efficient adaptation by default: If we assume that the preferences of an individual can be represented by utility $U$ being a function of a vector of market goods $X$ and an exogenous climate change component $C$, the individual maximises utility subject to their budget $Y$ and price vector $P$.

$\operatorname{Max} U(\boldsymbol{X}, \mathrm{C})$, s.t. $\boldsymbol{P} \boldsymbol{X}=Y$,

The set of demand functions for the individual can be derived by assuming suitable separability assumptions (using Roy's identity) for market goods $X$. The demand for goods $X_{1}$ is not dependant on climate change, whereas the 
demand for goods $X_{2}$, the demand function will shift with changing climate, noted C.

$X_{1}=X \mathbf{1}(P, Y)$

$X_{2}=X 2(P, Y, C)$

An individual may choose to purchase some capital good $\mathbf{K}$, such as shelter, due to climate change. When buying capital goods, the individual aims at maximising utility over time. By assuming that a single capital good is bought in the first period, but it brings utility over time, the utility maximisation becomes

$\operatorname{Max} U_{t}(X, \mathrm{C}, K) e^{-r t} d t \quad$ s.t. $\int\left[Y_{t}-P_{x} X t\right] e^{-r t}-P_{k} K=0$

Taking the first-order condition of [6], we see that the marginal stream of utility over time from the capital good should equal the price of capital at the optimum:

$P_{K}=\int\left(d U_{t}(X, \mathrm{C}, K) / d K\right) e^{-r t} d t$

Therefore, climate change will affect the consumption of the capital good $\mathrm{K}$ if the marginal utility from the good depends on climate change.

The efficiency of societal, or public level CCA, where decisions affect many people, is defined in Mendelsohn (2012) by a set of CCA projects that maximize net benefits (Mendelsohn, 2000). For public sector decision-making, the efficient amount of CCA maximises net aggregate benefits:

$$
\operatorname{Max} \sum B_{i}(Q)-C(Q)
$$

where $\sum B_{i}(Q)$ is the aggregate benefits of the CCA project for $i$ agents, and $C(Q)$ is the cost of the CCA project. Maximizing with respect to $\mathrm{Q}$ yields the first order condition:

$$
M C(Q)=\sum M B_{i}(Q)
$$

implying that the public sector should implement CCA projects to the point where the marginal cost of the project equals the sum of the marginal benefit of CCA across all individuals. Economically, the optimal set of DRM measures without a changing climate should fulfil the same criteria as for CCA: the efficient set of DRM projects is the set of DRM projects that maximize net benefits.

Climate change will, however, increase the uncertainty related to the criteria of effectiveness and efficiency (Hallegatte et al., 2012; Lempert, 2014; Lempert and Groves, 2010; Sussman et al., 2014b, 2014a). Assessing and achieving effectiveness may not be straightforward because of i) the uncertainties inherent in measuring the effectiveness of 'softer' DRM and CCA measures, ii) the actions taken by agents other than the one implementing the measure and 
iii) the uncertainty regarding the future state of the world (elaborated in Section 2.2.3). As noted by Konrad and Thum (2014), there is a risk that a response to expected climate change may initially seem cost-effective but turn out to be expensive or ineffective when climate change does not develop as expected.

This emphasises the challenge related to long-term uncertainty due to climate change, socio-economic and political development (Toth, 2008), as explained in section 2.2.3. Therefore, CCA has been noted as mainly being an iterative process where learning (Baird et al., 2014; Berkhout et al., 2006; Tschakert and Dietrich, 2010) is a key component for successful CCA and initial investments should be put on flexible and robust measures (Dessai and Hulme, 2007; Hallegatte et al., 2012; Lempert and Groves, 2010, Konrad \& Thum, 2014). This would potentially avoid the three forms of inefficient and ineffective CCA: under adaptation, over adaptation (Hanemann, 2000) and maladaptation (Barnett and O'Neill, 2010, p. 211): "action taken ostensibly to avoid or reduce vulnerability to climate change that impacts adversely on, or increases the vulnerability of other systems, sectors or social groups".

To develop policies and measures that perform effectively despite future deep uncertainty, a wide range of plausible scenarios are typically assessed (Walker et al., 2010; Maier et al, 2016) and models to account for deep uncertainty have been developed (Lempert et al., 2003). Based on scenario analysis, robust policies and measures-i.e. those that perform adequately in multiple climatic and societal future scenarios-can be designed and applied; thereby, reducing the current risk and providing benefits in multiple futures despite the deep uncertainty inherent in the climatic and societal systems (Dessai et al., 2009; Fankhauser et al., 1999; Maier et al., 2016). Preparing and reducing the risks of 'Black swan' events (Taleb, 2007), also follows the idea of developing robust, flexible and adaptive systems (Aven, 2015).

Assessing the effectiveness and efficiency is relatively straightforward for concrete DRM and CCA projects, such as a dyke for flood protection. However, public sector DRM and CCA can also refer to less tangible policies and projects, such as Research and Development investments or poverty reduction, where efficiency may not be the sole decision criteria. Furthermore, equity and legitimacy of DRM and CCA are important when defining successful, integrated, DRM and CCA. Equity refers to the distributional effects, or 'fairness' of DRM and CCA decisions (Adger et al., 2005; Hallegatte et al., 2016) and, according to Adger et al (2005, p.83) legitimacy is the "extent to which decisions are acceptable to participants and non-participants that are affected by those decisions". 


\section{APPROACH: FROM QUALITATIVE TO QUANTITATIVE ANALYSIS}

The theoretical background for this thesis illustrates the complexity of the topic. Therefore, the research question is a prime example of a topic which requires the use of mixed methods: a combination of qualitative and quantitative approaches for data collection and analysis to understand the complexity of the issue. As stated in Phillips (2014), both quantitative and qualitative methods are valid ways to study disasters. Furthermore, as stated by Dunn (2015), policy analysis-of which articles I, II and IV can be considered to be a part-is "methodologically eclectic". The main aim of policy analysis should be to produce reliable, policy-relevant knowledge, not to be confined by a certain methodology. Policy analysis should be pragmatic, as the challenges in public policy are economic, political, cultural, ethical and more (Dunn, 2015). This section describes first the justification behind mixed methods research and the qualitative and quantitative research approaches used. All data and methods are described in more detail in the articles.

\subsection{Mixed methods research}

Broadly categorised, four types of exogenously collected data exist for both quantitative and qualitative research: interviews, questionnaires, documents and observations. Interview transcripts can lead to quantitative data on the content (e.g. word count) or qualitative data in terms of the information obtained from the interviews. Questionnaires can have closed questions leading to quantitative data and open-ended question leading to qualitative data. Documents can be official statistics used for quantitative analysis or can result in quantitative content data. Documents are also a common data source for qualitative analysis and can consist of e.g. policy documents or personal diaries. Observations are the basis for many quantitative analyses, whether the observed variable is "natural" or "societal", and in qualitative research observations can come from, for instance, interactions between people, pictures or events. (Denscombe, 2007) The difference between quantitative and qualitative research is, therefore, not in the data sources but in the nature of the data, or the types of units analysed, and how the analysis is performed. (Robson, 2002).

Both quantitative and qualitative methods have their strengths and weaknesses (see Johnson and Onwuegbuzie, 2004 for a thorough list). The premise of mixed method research is to take advantage of the strengths and minimise the weaknesses (Johnson and Onwuegbuzie, 2004) by being "an approach to knowledge (theory and practice) that attempts to consider multiple viewpoints, perspectives, positions, and standpoints (always including the standpoints of qualitative and quantitative research)" (Johnson et al., 2007, p. 113). As Johnson and Onwuegbuzie (2004, p. 17-18) note, the research question should guide the choice of the research approach: "research 
methods should follow research questions in a way that offers the best chance to obtain useful answers".

Two major categories of mixed methods research have been defined: mixedmodel and mixed-method. Mixed-model implies that the research design mixes qualitative and quantitative approaches within or across the stages of the research process, for instance a questionnaire includes both qualitative and quantitative questions (within) or quantitative analysis is performed on qualitative data (across). Mixed-method implies that the overall research design includes both a quantitative phase and a qualitative phase. (Johnson and Onwuegbuzie, 2004) This thesis uses the mixed-method approach, as the overall aim is analysed in parallel both with quantitative and qualitative methods.

\subsection{Qualitative approach: Semi-structured interviews and policy documents}

Several ways of collecting, processing and analysing qualitative data exist. Interviews are a suitable method for data collection in cases when the research interests are complex and subtler than what, for instance, questionnaires could reveal. Interviews are particularly suitable for situations when the research interest lies in people's opinions, feelings, emotions or experiences (Denscombe, 2007). Policy documents are a common source of data in policy research (Yanow, 2007).

The semi-structured interview is an interview method where the questions are open-ended; the direction or the character of the answer is open and prompts and probes are used in case the interviewer thinks more information could be disclosed (Gillham, 2005). Prompts, on the one hand, are based on other data or previous interviews and are used if the interviewee does not automatically mention something potentially relevant. The use of prompts ensures that all interviews have comparable coverage of issues; however, interviewees need to be prompted in a way so as not to lead their responses. Probes, on the other hand, are supplementary questions or responses that are used during the interview, for example, to clarify, justify or give an example of something that has been raised during the interview. Gillham (2005, p. 70) states that "it could be argued that the semi-structured interview is the most important way of conducting a research interview because of its flexibility balanced by structure". (Gillham, 2005, 2000).

The common steps in qualitative data analysis are: preparing the data, becoming familiar with the data, interpreting the data, verifying the data and presenting the data. The first two steps, preparation and familiarisation, and the last step of presentation are relatively similar to quantitative data analysis; however, the interpretation and verification of data differ notably from quantitative research. Interpretation of the data consists generally of four steps: i) coding the data, ii) categorising the codes, iii) identifying themes and 
relationships among the codes and categories and iv) developing concepts and arriving at generalised statements (i.e. drawing conclusions). (Denscombe, 2007) Coding of qualitative data is the process of organising and sorting the raw data.

Data verification implies that there needs to be a way to show that the research is credible. Showing credibility in qualitative research is not a simple task; qualitative research, by nature, leaves more room to the interpretations of the researcher and replicability of the research is not necessarily as easy as quantitative analysis. However, research procedures such as triangulation (i.e. using "contrasting data sources to bolster confidence that the data are "on the right lines" Denscombe, 2007, p. 297) and an audit trail (i.e. describing the research path and decisions taken during the entire process) are ways to increase the credibility of the qualitative research findings (Denscombe, 2007).

\subsection{Quantitative approach: Cost Benefit Analysis}

Decision-making at any level is based on certain explicit or tacit knowledge (Herschel et al., 2001; Wyatt, 2001). One tool, or an element, to increase the level of explicit knowledge for decision making is Cost Benefit Analysis (CBA). CBA aims at monetising and, thereby, comparing the various benefits of a policy or a project in terms of its costs. An increase in individual wellbeing is defined as the benefits, and a decrease in wellbeing as the costs. (Arrow et al., 1996; Boardman et al., 2010; Nyborg, 2014)

CBA as a tool is based on general welfare economics, aiming to maximise the aggregate welfare or social utility through the implementation of projects with the highest net economic benefits. Based on the Kaldor-Hicks efficiency criterion, each project is assumed to involve winners and losers; and the gains and losses are aggregated through a social welfare function. The social welfare function is maximised assuming that a 'benevolent dictator', a.k.a. a social planner, ranks the projects according to the efficiency metrics given by CBA and the winners of the project provide compensation of the lost welfare to the losers, yet still remaining better off than without the project (Boadway, 1974; Nyborg, 2014). The Kaldor-Hicks efficiency criterion does not necessarily require actual compensation to be paid; if compensation is paid, the project fulfils the criterion for Pareto improvement (Coleman, 1980) (see a formal presentation of the standard use of CBA for CCA in Nurmi, 2019).

In principle, CBA could work as a social decision rule (not a tool or element) whereby policies and projects are ranked based on the net benefit criterion. This criterion is based on subtracting the project costs from the aggregated benefits, which leads to a simple rule that can be used to compare different projects and decide the one which has the highest net benefit, i.e. the most cost efficient. 
Several shortcomings with CBA have, however, been identified. These prevent its use as the only rule in social decision-making (Arrow et al., 1996; Nyborg 2014). The treatment of distributional aspects within and between generations is a fundamental aspect in CBA (Nurmi, 2019), which has been discussed both from theoretical (Boadway, 1974) and ethical (Nyborg, 2014) perspectives. Particularly in climate change mitigation studies, the valuation of intergenerational costs and benefits with the correct discount rate has spurred debate (Arrow et al., 2013; Dasgupta, 2008; Sussman et al., 2014b; Weitzman, 2011, 2001). Other key challenges related to CBA in DRM and, particularly, CCA studies are imperfect benefit valuation methods, tendency to favour monetised costs and benefits, the treatment of non-quantifiable costs and benefits, (Smith et al., 2017), ubiquity of impacts, intangibility, non-marginal changes, long timeframes (Sussman et al., 2014b) and most importantly, uncertainty (Section 2.2.3) (e.g. Graham, 1981; Hallegatte et al., 2012; Li et al., 2014; Smith et al., 2017; Thorarinsdottir et al., 2017). Despite these challenges, Hallegatte et al. (2012) and Sussman et al. (2014b) conclude that CBA has value in decision-making for CCA, particularly as a complementary, supporting tool but its limitations in the assessment phase and interpretation phase should not be ignored. 


\section{SUMMARIES OF THE ARTICLES}

\section{Article I: Defining Climate Change Adaptation and Disaster Risk Reduction Policy Integration: Evidence and Recommendations from Zambia}

Article I aims to increase the understanding of Disaster Risk Reduction (DRR) and Climate Change Adaptation (CCA) policy integration as a means for effective and efficient management of weather and climate change related risks. The study i) defines integration at horizontal (inter-ministerial) and vertical (intra-ministerial) dimensions, ii) refines a policy integration cycle and iii) presents an analytical framework to assess DRR and CCA policy integration in policy formulation and implementation phases. The policy level focus is taken because policies guide actions, and integration at the policy level could deepen the overall integration of DRR and CCA (IPCC, 2012).

The empirical component of the study was undertaken in Zambia. First, the IPCC (2014b) risk framework was used to describe the risk from natural hazards and climate change in Zambia; the risk from natural hazards and climate change is assessed from hazard and climate change, vulnerability and exposure persepctives. Second, the analysis focuses on organisations' roles in, and actors' views on DRR and CCA policy integration to identify potential opportunities for, and challenges to, policy integration. Uncertainty is not explicitly analysed, but the article is framed to address the uncertainty increased by climate change on natural hazards. The data cover semistructured interviews, policy documents and the government budget plan.

The main contribution of the article is the definition of DRR and CCA policy integration. Following the idea from the literature that CCA policy objectives should be integrated into DRR, and based on the policy integration definitions given in Lafferty and Hovden (2003) and Mickwitz and Kivimaa (2007), the integration of CCA policies into DRR policies can be defined as i) the incorporation of CCA policy objectives into all stages of DRR policy making and ii) accompanied by an attempt to aggregate anticipated impacts of climate change into an overall evaluation of the DRR policy and a commitment to minimise the contradictions between CCA and DRR policies and implementation processes. 


\section{Article II: Adaptation by the Least Vulnerable: Managing Climate and Disaster Risks in Finland}

Article Paper II focuses on vulnerability reduction as a key to reduce disaster and climate change risk. It addresses the contribution of the underlying risk drivers of governance, societal and political factors, culture, policies and their implementation to DRM and CCA. Most importantly, the role of five factors that constitute 'the elephant in the room' in DRM publications and gatherings, as suggested by Alexander and Davis, (2012) is addressed: the i) human right to hazard information, 2) explosive population growth, iii) corruption, iv) how people are placed at risk by the actions of governments and v) gender discrimination. More specifically, the aim of the article is two-fold: i) to describe the Finnish model and the role of governance and society for DRM and CCA and ii) to analyse and problematise the existing frameworks that guide-or are designed to guide-the theoretical and practical fields of DRM and CCA through the findings of the case description.

The article focuses on vulnerability reduction as a key aspect in reducing disaster and climate change risk. The theoretical contribution furthers discussion on the new dimensions in climate change risk analyses by emphasising the potential impacts of societal development, such as social trends and social cohesion, in effective DRM and CCA. The main contribution is an analysis that focuses on a Nordic welfare state, often forgotten in the literature when addressing the underlying reasons for disaster risk creation.

The risk of extreme weather events and climate change is addressed through the IPCC (2014b) and PAR (Wisner et al., 2003) frameworks. The article provides an insight into a successful case of DRM and CCA, as Finland can be seen as a country where strict public regulation, societal progress and major investments in ensuring that all vital societal functions work in exceptional situations have resulted in a country where natural hazards do not turn into disasters and where climate change may actually bring beneficial opportunities if successfully harnessed. Uncertainty is not explicitly studied, but the role of uncertainty due to climate change and its impacts, and changes in societal structures in the risk analysis frameworks is implicitly discussed.

The article concludes that disaster risk assessments need to be contingent and account for social and economic contexts. In an institutionally wellfunctioning welfare society, vulnerability assessments should emphasize relative changes in perceived social trends and social cohesion. Exposure should not be limited to direct geographical or physical exposure to local natural hazards. Successful opportunity identification can help improve DRM at home and abroad. 


\section{Article III: Overadaptation to Climate Change? The Case of the 2013 Finnish Electricity Market Act}

Article III serves as an example of the Finnish approach to DRR and CCA, described in Article II. First, Article III provides a mathematical definition for economic over-adaptation; i.e. the marginal benefits of the investment to reduce disaster risk and adapt to climate change exceed the marginal cost of the DRR and CCA policy measure.

Second, an illustrative case is provided in which the response to extreme weather risk, while aligned with the goals of CCA, is implemented beyond the economically efficient scale. The article provides an in-medias-res CBA of the 2013 Finnish Electricity Market Act (Sähkömarkkinalaki, 2013), enacted partially as a reaction to long, storm-induced electricity blackouts experienced after 2000 and particularly the long, widespread blackouts experienced in the 2011-2012 winter. The changing risk due to climate change is mentioned as one incentive to change the legislation. The Act imposes strict requirements on electricity distribution companies with regards to the duration of blackouts. Meeting the requirements entails investments amounting to approximately one billion euro, due to converting the infrastructure from overhead to underground cabling. As a benefit, the avoided cost from the blackouts for households and producers is quantified.

Uncertainty in the parameter values regarding the future development of climate change and other socio-economic factors affecting the CBA were derived from Monte-Carlo simulations. The results show that for urban areas, the net expected value is positive. However, in rural areas less strict requirements could have been economically more efficient, implying that flexible, less costly measures compared to underground cabling could have been used. The results indicate that the distributional impacts and correspondence between those who benefit and those who pay the costs should be considered in DRR and CCA policies that require large-scale investments.

The article shows that over-adaptation, leading to inefficient allocation of resources from an economic persective, effectively reducses the risk of extreme weather and climate change, but may not be accepted by the public as a viable way of reducing risk due to the high level of investment cost and the consequent significant rise in electricity prices. 


\section{Article IV: Innovations in weather services as a crucial building block for climate change adaptation in road transport}

Article IV assessed the effects of improved weather service provision on the safety of road transport to improve CCA in the road transport sector. The objectives of the article are to: i) identify and describe the main trends and potential innovations in the provision and use of weather services in the road transport sector, ii) identify where in the weather service provision value chain these innovations would have an impact on the use of weather information before and during the trip and iii) analyse the expected magnitude of the value of these innovations. The analysis is based on a Weather Service Chain Analysis framework (Nurmi et al., 2013). The framework puts emphasis on the accuracy of the information, how it is disseminated, received and how the end user responds to the information; thereby, analysing the information decay throughout the value chain and resulting in an estimate of the fraction of the benefit potential realized. It provides an advantage over modelling approaches, such as the Cost-loss model (Katz and Murphy, 1997) that relies solely on forecast accuracy in assessing the benefits of information provided.

The study is based on 12 semi-structured expert interviews which aimed at identifying the trends and potential innovations in the provision and use of weather services and analyses the value of these innovations in the weather service provision value chain. Risk and uncertainty are key concepts. An uncertain changing climate will pose new risks to the road transport sector. Due to the uncertainty, robust methods are needed to reduce the risk in the changing conditions. Uncertainty is addressed through sensitivity analysis.

The largest gaps in the benefit realisation are related to access to up-to-date information and drivers' ability to respond. A large share of the drivers do not acquire weather information prior to their trips and base their opinions during the trip on the weather conditions mainly through their own observations. Therefore, development in the communication technology is a key enabler in this step. New ways to reach vehicle drivers, such as applications on mobile devices, services for satellite navigation devices and variable message systems are being developed. 


\section{CONCLUSIONS}

The main research question of this thesis was to assess potential means to overcome the salient challenges in developing and applying DRM and CCA policies and measures that are designed to reduce the risks posed by extreme weather under uncertainty. This was achieved by identifying and analysing challenges related to DRM and CCA integration and their further integration into sectoral policies; exploring how governance, other socio-cultural structures, policies and their implementation can effectively reduce disaster risk and analysing the efficiency, effectiveness and legitimacy of DRM and CCA measures. It has contributed to the empirical analysis of integrated DRR and CCA policies and measures, and has analysed challenges related to their development and implementation. Theoretically, it advances the policy level development of DRR and CCA integration and provides a mathematical definition for over-adaptation to climate change.

Article I identifies that vulnerability reduction has not been the main focus of DRM and CCA policies in Zambia. Furthermore, even though the importance of integration is recognised by some actors, major challenges for integration in Zambia include siloed governance structures, lack of capacity in the relevant government organisations, coordination of multi-level governance and institutional lock-in. An important consideration should be to integrate long term CCA into existing DRM policies and measures and jointly integrate them in all relevant sectorial policies to effectively reduce the risk of disasters and climate change.

Article II shows that in Finland, the governance of DRM and CCA follow, to some extent, similar structures as in Zambia: DRM and CCA are the responsibility of different ministries, thereby, potentially causing inefficiencies in governance. However, the integration of DRM in sectorial policies is advanced, thus reducing potential inefficiencies. Furthermore, the Nordic Welfare State, its related governance structure and policy interventions, was shown to be effective in reducing societal and human vulnerabilities and in developing legislation that reduces disaster and climate change impacts.

The case in Article III serves as an example of the Finnish approach to DRM and CCA: it shows that a policy has the potential to substantially reduce the risk of extreme weather and climate change, but may not be accepted by the public anymore to the high level of investment cost and the consequent significant rise in electricity prices. The results indicate that distributional impacts and correspondence between those who benefit and those who pay the costs should be taken into account in DRM and CCA policies that require largescale investments. Furthermore, in the case of over-investment, the population affected by a disaster may not accept DRR and CCA that are 
successful in terms of regulation and implementation. This applies when societal and individual preferences do not coincide.

Article IV shows how technological innovations, and the provision of improved weather information can decrease the impacts of extreme weather events on individuals. However, decision-making at individual level is still one of the defining factors behind the impacts; increasing information provision may not improve this but may require advances in technologies to overcome the challenge of human decision-making.

Despite the increasing number of studies focusing on the topic, no explicit definition has been provided in the literature for DRM and CCA policy integration. The lack of definition may not result in concrete inefficiencies or ineffectiveness in practice, but an explicit definition for integration aims at improving the systematic assessment of policy documents and other data in analysing DRM and CCA integration. At the practical level, the results from Zambia show how international discussion and local level experiences have increased the understanding of the linkages between DRR and CCA and initiated their integration. Although the benefits of integration are known among the key actors, the status quo is yet to be challenged, leading to parallel, inter-linked and potentially inefficient governance systems.

Even though integration, or mainstreaming DRM with the long-term CCA perspective in all relevant policy sectors-such as water management, agriculture, energy etc.-has gained increasing attention, it is still in its infancy. Integration in sectorial policies is at the core of efficient and effective DRM and CCA. Disasters and climate change do not operate in silos but affect most policy and economic sectors.

A prominent example of government intervention in Finland is the Electricity Market Act 2013, where the sectorial policy will effectively reduce the impacts of extreme weather; however, it suffered from lack of legitimacy among the public. This highlights the need to consider public opinion and potential and perceived negative effects on the public and emphasises the need for flexible and adaptive policies. For instance, Willingness-to-Pay studies prior to a major policy change could be warranted to avoid similar backlashes that took place in Finland. Effectiveness of the envisaged measures is a key criterion in designing DRM and CCA measures; however, the challenge for policy-makers is to design instruments that are accepted by the public. Even though most of the analyses in this thesis has focused on policies and large-scale investments for DRR and CCA developed mainly by public authorities, the decision-making level of an individual in DRR and CCA should not be forgotten. Individual level decision-making and actions become important before, during and after a severe weather or disaster situation. Even if the information provided has reached its full potential, people do not necessarily respond optimally, and human behaviour and decision-making are still the key factors in contributing to reducing the potential impacts from adverse weather conditions. Some 
responses to this challenge may arise from technology, particularly in road transport where major technological development is foreseen, but until the technological potential is reached, severe weather will lead to accidents and disasters due to lack of behavioural adaptation.

The main limitations of the thesis are related to the "snap shot" and case study nature of the studies. The articles could have been deepened, at least, in the following ways. Article I on the integration of DRR and CCA policies in Zambia is a snapshot of a moving target; a longitudinal, or a follow up, study on the policy landscape and measure implementation would be needed to conclude whether the situation is still valid, whether the recommendations given in the article were feasible and whether their potential implementation resulted in a more effective and efficient DRR and CCA. Even more interestingly, the definition for horizontal and vertical level integration of DRR and CCA policies should be analysed in various contexts, for instance in the European Union, to understand the current situation and potential challenges at a wider scale. Article II would have benefitted from collaboration with experts in political systems, such as the Nordic Welfare State, to further analyse the role of political systems and culture in DRR and CCA. Article III would have benefitted from a more thorough analysis of the willingness-to-pay for electricity blackouts, which may also change in the future; thereby, changing the results of the study. Furthermore, uncertainties regarding technological development in electricity production were omitted from the analysis. Article IV would have benefitted from collaboration with experts in behavioural science to improve our understanding of individual decision-making based on uncertain information, conflicting priorities of individuals and the lack of will to act in an effective way. These limitations can be turned into potential future research and call for inter-disciplinary approaches to address the abovementioned shortcomings. However, noteworthy is that in the 'field' of this thesis, what matters in the end is action.

Lack of knowledge is not the most salient challenge regarding DRM and CCA. Research can contribute to increasing our knowledge only to some extend; the most important next steps are the actions taken by policy makers, practitioners and individuals in all fields of policy and practice to build the bridge between the inundated shores of DRM and CCA. 


\section{REFERENCES}

Adelle, C., Russel, D. 2013. Climate Policy Integration: a Case of Déjà Vu?

Environmental Policy and Governance 23, 1-12.

https://doi.org/10.1002/eet.1601

Adger, W.N., Arnell, N.W., Tompkins, E.L. 2005. Successful adaptation to climate change across scales. Global Environmental Change 15, 7786. https://doi.org/10.1016/j.gloenvcha.2004.12.005

Adger, W.N., Dessai, S., Goulden, M., Hulme, M., Lorenzoni, I., Nelson, D.R., Naess, L.O., Wolf, J., Wreford, A. 2009. Are there social limits to adaptation to climate change? Climatic Change 93, 335-354. https://doi.org/10.1007/s10584-008-9520-z

Alexander, D. \& Davis, I. 2012. Disaster risk reduction: An alternative viewpoint. International Journal of Disaster Risk Reduction 2, 1-5. https://doi.org/10.1016/j.ijdrr.2012.10.002

Alley, R.B., Marotzke, J., Nordhaus, W.D., Overpeck, J.T., Peteet, D.M., Pielke, R.A., Pierrehumbert, R.T., Rhines, P.B., Stocker, T.F., Talley, L.D., Wallace, J.M. 2003. Abrupt Climate Change. Science 299, 20052010. https://doi.org/10.1126/science.1081056

Amundsen, H., Berglund, F., \& Westskog, H. 2010. Overcoming Barriers to Climate Change Adaptation-A Question of Multilevel Governance? Environment and Planning C: Government and Policy 28(2), 276289. https://doi.org/10.1068/c0941

Arrow, K., Cropper, M., Gollier, C., Groom, B., Heal, G., Newell, R., Nordhaus, W., Pindyck, R., Pizer, W., Portney, P., Sterner, T., Tol, R.S.J., Weitzman, M. 2013. Determining Benefits and Costs for Future Generations. Science 341, 349-350. https://doi.org/10.1126/science.1235665

Arrow, K.J. 1971. Essays in the Theory of Risk Bearing. Markham, Chicago.

Arrow, K.J., Cropper, M.L., Eads, G.C., Hahn, R.W., Lave, L.B., Noll, R.G., Portney, P.R., Russell, M., Schmalensee, R., Smith, V.K. 1996. Is there a role for benefit-cost analysis in environmental, health, and safety regulation? Science-AAAS-Weekly Paper Edition 272, 221-222.

Arvesen, A., Bright, R.M., Hertwich, E.G. 2011. Considering only first-order effects? How simplifications lead to unrealistic technology optimism in climate change mitigation. Energy Policy 39, 7448-7454. https://doi.org/10.1016/j.enpol.2011.09.013

Aven, T. 2015. Implications of black swans to the foundations and practice of risk assessment and management. Reliability Engineering \& System Safety 134, 83-91.

Baird, J., Plummer, R., Haug, C., Huitema, D. 2014. Learning effects of interactive decision-making processes for climate change adaptation. Global Environmental Change 27, 51-63. https://doi.org/10.1016/j.gloenvcha.2014.04.019

Baker, I., Peterson, A., Brown, G., McAlpine, C. 2012. Local government response to the impacts of climate change: An evaluation of local climate adaptation plans. Landscape and Urban Planning 107, 127136. https://doi.org/10.1016/j.landurbplan.2012.05.009 
Barnett, J., O'Neill, S. 2010. Maladaptation. Global Environmental Change 20, 211-213. https://doi.org/10.1016/j.gloenvcha.2009.11.004

Barthel, F., Neumayer, E. 2012. A trend analysis of normalized insured damage from natural disasters. Climatic Change 113, 215-237. https://doi.org/10.1007/s10584-011-0331-2

Bauer, A., Feichtinger, J., Steurer, R. 2012. The governance of climate change adaptation in 10 OECD countries: challenges and approaches. Journal of Environmental Policy \& Planning 14, 279-304. https://doi.org/10.1080/1523908X.2012.707406

Baxter, P., Jack, S. 2008. Qualitative Case Study Methodology: Study Design and Implementation for Novice Researchers. The Qualitative Report 13, 544-559.

Beck, U. 1992. Risk Society: Towards a New Modernity. Sage, New Delhi.

Berkhout, F., Hertin, J., Gann, D.M. 2006. Learning to Adapt: Organisational Adaptation to Climate Change Impacts. Climatic Change 78, 135-156. https://doi.org/10.1007/s10584-006-9089-3

Biagini, B., Bierbaum, R., Stults, M., Dobardzic, S., McNeeley, S.M. 2014. A typology of adaptation actions: A global look at climate adaptation actions financed through the Global Environment Facility. Global Environmental Change 25, 97-108. https://doi.org/10.1016/j.gloenvcha.2014.01.003

Boadway, R.W. 1974. The Welfare Foundations of Cost-Benefit Analysis. The Economic Journal 84, 926-939.

Boardman, A., Greenberg, D., Vining, A., Weimer, D. 2010. Cost-Benefit Analysis, 4 edition. ed. Prentice Hall, Boston.

Bogardi, J.J. 2006. Introduction, in: Birkmann, J. (Ed.), Measuring Vulnerability to Natural Hazards: Towards Disaster Resilient Societies. United Nations University Press, Tokyo; New York; Paris.

Bond, T.C., Doherty, S.J., Fahey, D.W., Forster, P.M., Berntsen, T., DeAngelo, B.J., Flanner, M.G., Ghan, S., Kärcher, B., Koch, D., Kinne, S., Kondo, Y., Quinn, P.K., Sarofim, M.C., Schultz, M.G., Schulz, M., Venkataraman, C., Zhang, H., Zhang, S., Bellouin, N., Guttikunda, S.K., Hopke, P.K., Jacobson, M.Z., Kaiser, J.W., Klimont, Z., Lohmann, U., Schwarz, J.P., Shindell, D., Storelvmo, T., Warren, S.G., Zender, C.S. 2013. Bounding the role of black carbon in the climate system: A scientific assessment. Journal of Geophysical Research: Atmospheres 118, 5380-5552. https://doi.org/10.1002/jgrd.50171

Burton, I., Huq, S., Lim, B., Pilifosova, O., Schipper, E.L. 2002. From impacts assessment to adaptation priorities: the shaping of adaptation policy. Climate Policy 2, 145-159. https://doi.org/10.3763/cpol.2002.0217

Carmin, J., Dodman, D. 2013. Engaging science and managing scientific uncertainty in urban climate adaptation planning, in: Moser, S.C., Boykoff, M.T. (Eds.), Successful Adaptation to Climate Change Linking Science and Policy in a Rapidly Changing World. Routledge, London, p. 360. https://doi.org/10.4324/9780203593882-24

Carrão, H., Naumann, G., Barbosa, P. 2016. Mapping global patterns of drought risk: An empirical framework based on sub-national estimates of hazard, exposure and vulnerability. Global 
Environmental Change 39, 108-124.

https://doi.org/10.1016/j.gloenvcha.2016.04.012

Carter, T., Parry, M., Harasaza, H., Nishioka, S. 1994. IPCC Technical

Guidelines for Assessing Climate Change Impacts and Adaptations

(Part of the IPCC Special Report to the First Session of the Conference of the Parties to the UN Framework Convention on Climate Change, Intergovernmental Panel on Climate Change. Department of Geography, University College London, UK and Center for Global Environmental Research, National Institute for Environmental Studies, Tsukuba, Japan).

Changnon, S.A., Pielke Jr, R.A., Changnon, D., Sylves, R.T., Pulwarty, R. 2000. Human factors explain the increased losses from weather and climate extremes. Bulletin of the American Meteorological Society 81, 437.

Coleman, J.L. 1980. Efficiency, Exchange, and Auction: Philosophic Aspects of the Economic Approach to Law Symposium: The Jurisprudence and Social Policy Program. Calif. L. Rev. 68, 221-249.

COM (European Commission). 2013. Communication from the Commission to the European Parliament, the Council, the European Economic and Social Committee and the Committee of the Regions - An EU Strategy on adaptation to climate change. $\operatorname{COM}(2013) 216$ final.

Corfee-Morlot, J., Cochran, I., Hallegatte, S., Teasdale, P.-J. 2011. Multilevel risk governance and urban adaptation policy. Climatic Change 104, 169-197. https://doi.org/10.1007/s10584-010-9980-9

Cornelissen, T., Diekkrüger, B., Giertz, S. 2013. A comparison of hydrological models for assessing the impact of land use and climate change on discharge in a tropical catchment. Journal of Hydrology 498, 221236. https://doi.org/10.1016/j.jhydrol.2013.06.016

Cutter, S. L., \& Finch, C. 2008. Temporal and spatial changes in social vulnerability to natural hazards. Proceedings of the National Academy of Sciences of the United States of America 105(7), 23012306.

https://doi.org/www.pnas.org/cgi/doi/10.1073/pnas.0710375105

Dasgupta, P. 2008. Discounting climate change. Journal of Risk and Uncertainty 37, 141-169.

de Bruin, K., Dellink, R.B., Ruijs, A., Bolwidt, L., van Buuren, A., Graveland, J., de Groot, R.S., Kuikman, P.J., Reinhard, S., Roetter, R.P., Tassone, V.C., Verhagen, A., van Ierland, E.C. 2009. Adapting to climate change in The Netherlands: an inventory of climate adaptation options and ranking of alternatives. Climatic Change 95, 23-45.

https://doi.org/10.1007/s10584-009-9576-4

Denscombe M. 2007. The good research guide for small-scale social projects. Third Edition. Open University Press. Maidenhead, England: McGraw Hill. ISBN 978 o 335220229

Dessai, S., Hulme, M. 2007. Assessing the robustness of adaptation decisions to climate change uncertainties: A case study on water resources management in the East of England. Global Environmental Change 17, 59-72. https://doi.org/10.1016/j.gloenvcha.2006.11.005

Dessai, S., Hulme, M., Lempert, R., Pielke Jr, R. 2009. Do We Need Better Predictions to Adapt to a Changing Climate? Eos 90, 111-112. 
Devereux, S. 2016. Social protection for enhanced food security in subSaharan Africa. Food Policy, Towards a food secure future: Ensuring food security for sustainable human development in Sub-Saharan Africa 60, 52-62. https://doi.org/10.1016/j.foodpol.2015.03.009

Dietz, T., Ostrom, E., Stern, P.C. 2003. The Struggle to Govern the Commons. Science 302, 1907-1912. https://doi.org/10.1126/science.1091015

Djalante, R., Holley, C., Thomalla, F., \& Carnegie, M. 2013. Pathways for adaptive and integrated disaster resilience. Natural Hazards 69(3), 2105-2135. https://doi.org/10.1007/s11069-013-0797-5

Dube, E. 2020. The build-back-better concept as a disaster risk reduction strategy for positive reconstruction and sustainable development in Zimbabwe: A literature study. International Journal of Disaster Risk Reduction 43, 101401.

Dunn, W.N. 2015. Public Policy Analysis. Routledge.

Dupont, C., Oberthür, S. 2012. Insufficient climate policy integration in EU energy policy: the importance of the long-term perspective. Journal of Contemporary European Research 8, 228-247.

Edenhofer, O., Pichs-Madruga, R., Y. Sokona, et al. 2014. Technical Summary. In: Climate Change 2014: Mitigation of Climate Change. Contribution of Working Group III to the Fifth Assessment Report of the Intergovernmental Panel on Climate Change [Edenhofer, O., R. Pichs-Madruga, Y. Sokona, E. Farahani, S. Kadner, K. Seyboth, A. Adler, I. Baum, S. Brunner, P. Eickemeier, B. Kriemann, J. Savolainen, S. Schlömer, C. von Stechow, T. Zwickel and J. C. Minx (eds.)]. Cambridge University Press, Cambridge, UK, and New York, NY, USA.

Emmerich, R. 2004. The Day After Tomorrow. 20th Century Fox.

Eriksen, S.H., O'Brien, K. 2007. Vulnerability, poverty and the need for sustainable adaptation measures. Climate Policy 7, 337-352. https://doi.org/10.1080/14693062.2007.9685660

Fankhauser, S., Smith, J.B., Tol, R.S.J. 1999. Weathering climate change: some simple rules to guide adaptation decisions. Ecological Economics 30, 67-78. https://doi.org/10.1016/So9218009(98)00117-7

Fidelman, P.I.J., Leitch, A.M., Nelson, D.R. 2013. Unpacking multilevel adaptation to climate change in the Great Barrier Reef, Australia. Global Environmental Change 23, 800-812. https://doi.org/10.1016/j.gloenvcha.2013.02.016

Fuss, S., Jones, C.D., Kraxner, F., Peters, G.P., Smith, P., Tavoni, M., van Vuuren, D.P., Canadell, J.G., Jackson, R.B., Milne, J., Moreira, J.R., Nakicenovic, N., Sharifi, A., Yamagata, Y. 2016. Research priorities for negative emissions. Environmental Research Letters 11, 115007. https://doi.org/10.1088/1748-9326/11/11/115007

Gero, A., Méheux, K., Dominey-Howes, D. 2011. Integrating disaster risk reduction and climate change adaptation in the Pacific. Climate and Development 3(4), 310-327. https://doi.org/10.1080/17565529.2011.624791

Gillham, B. 2005. Research Interviewing: The Range of Techniques. McGraw-Hill International.

Gillham, B. 2000. Research Interview. Bloomsbury. 
Gleditsch, N.P. 2012. Whither the weather? Climate change and conflict. Journal of Peace Research 49, 3-9. https://doi.org/10.1177/0022343311431288

Gollier, C. 2001. The Economics of Risk and Time. The MIT press, Cambridge, Massachusetts \& London, England.

Graham, D.A. 1981. Cost-benefit analysis under uncertainty. The American Economic Review 71, 715-725.

Hallegatte, S. 2009. Strategies to adapt to an uncertain climate change. Global Environmental Change 19, 240-247. https://doi.org/10.1016/j.gloenvcha.2008.12.003

Hallegatte, S., Shah, A., Lempert, R., Brown, C., Gill, S. 2012. Investment Decision Making under Deep Uncertainty - Application to Climate Change, Policy Research Working Papers. The World Bank. https://doi.org/10.1596/1813-9450-6193

Hallegatte, S., Vogt-Schilb, A.C., Bangalore, M., Rozenberg, J. 2016. Unbreakable : building the resilience of the poor in the face of natural disasters (English). Climate Change and Development series. Washington, D.C. World Bank Group. http://documents.worldbank.org/curated/en/512241480487839624/ Unbreakable-building-the-resilience-of-the-poor-in-the-face-ofnatural-disasters

Hanemann, W.M. 2000. Adaptation and its measurement: An Editorial Comment. Climatic Change 45, 571-581.

Hanley, N., Shogren, J.F., White, B. 1997. Environmental Economics in Theory and Practice. Palgrave, London.

Hardin, G. 1968. The Tragedy of the Commons. Science 162, 1243-1248. https://doi.org/10.1126/science.162.3859.1243

Harris, P. G. 2007. Collective Action on Climate Change: The Logic of Regime Failure. Natural Resources Journal 47, 195-224.

Herschel, R.T. Nemati, H. Steiger, D. 2001. Tacit to explicit knowledge conversion: knowledge exchange protocols. Journal of Knowledge Management 5, 107-116. https://doi.org/10.1108/13673270110384455

Highfield, W.E., Norman, S.A., Brody, S.D. 2013. Examining the 100-Year Floodplain as a Metric of Risk, Loss, and Household Adjustment. Risk Analysis 33, 186-191. https://doi.org/10.1111/j.15396924.2012.01840.x

IPCC. 2012. Managing the Risks of Extreme Events and Disasters to Advance Climate Change Adaptation: A Special Report of Working Groups I and II of the Intergovernmental Panel on Climate Change. Cambridge University Press, Cambridge, UK, and New York, NY, USA.

IPCC. 2014a. Annex II - Glossary. Agard, J., E.L.F. Schipper, J. Birkmann, M. Campos, C. Dubeux, Y. Nojiri, L. Olsson, B. Osman-Elasha, M. Pelling, M.J. Prather, M.G. Rivera-Ferre, O.C. Ruppel, A. Sallenger, K.R. Smith, A.L. St. Clair, K.J. Mach, M.D. Mastrandrea, and T.E. Bilir (eds.). In: Climate Change 2014: Impacts, Adaptation, and Vulnerability. Part B: Regional Aspects. Contribution of Working Group II to the Fifth Assessment Report of the Intergovernmental Panel on Climate Change [Barros, V.R., C.B. Field, D.J. Dokken, M.D. Mastrandrea, K.J. Mach, T.E. Bilir, M. Chatterjee, K.L. Ebi, Y.O. 
Estrada, R.C. Genova, B. Girma, E.S. Kissel, A.N. Levy, S.

MacCracken, P.R. Mastrandrea, and L.L. White (eds.)]. (pp. 17571776). Cambridge, United Kingdom and New York, NY, USA,:

Cambridge University Press.

IPCC. 2014b Climate Change 2014: Impacts, Adaptation, and Vulnerability.

Part A: Global and Sectoral Aspects. Contribution of Working Group II to the Fifth Assessment Report of the Intergovernmental Panel on Climate Change [Field, C.B., V.R. Barros, D.J. Dokken, K.J. Mach, M.D. Mastrandrea, T.E. Bilir, M. Chatterjee, K.L. Ebi, Y.O. Estrada, R.C. Genova, B. Girma, E.S. Kissel, A.N. Levy, S. MacCracken, P.R. Mastrandrea, and L.L. White (eds.)]. Cambridge University Press, Cambridge, United Kingdom and New York, NY, USA, 1132 pp.

Ireland, P. 2010. Climate change adaptation and disaster risk reduction: Contested spaces and emerging opportunities in development theory and practice. Climate and Development 2, 332-345. https://doi.org/10.3763/cdev.2010.0053

Ishii, A., Langhelle, O. 2011. Toward policy integration: Assessing carbon capture and storage policies in Japan and Norway. Global Environmental Change, Special Issue on The Politics and Policy of Carbon Capture and Storage 21, 358-367. https://doi.org/10.1016/j.gloenvcha.2011.02.005

Johnson, R.B., Onwuegbuzie, A.J. 2004. Mixed Methods Research: A Research Paradigm Whose Time Has Come. Educational Researcher 33, 14-26.

Johnson, R.B., Onwuegbuzie, A.J., Turner, L.A. 2007. Toward a Definition of Mixed Methods Research. Journal of Mixed Methods Research 1, 112133. https://doi.org/10.1177/1558689806298224

Jordan, A., Lenschow, A. 2010. Environmental policy integration: a state of the art review. Environmental Policy and Governance 20, 147-158. https://doi.org/10.1002/eet.539

Kahneman, D., Tversky, A. 1979. Prospect Theory: An Analysis of Decision under Risk. Econometrica 47, 263-292.

Kane, S., Shogren, J.F. 2000. Linking Adaptation and Mitigation in Climate Change Policy. Climatic Change 45, 75-102. https://doi.org/10.1023/A:1005688900676

Kates, R.W., Travis, W.R., Wilbanks, T.J. 2012. Transformational adaptation when incremental adaptations to climate change are insufficient. Proceedings of the National Academy of Sciences 109, 7156-7161. https://doi.org/10.1073/pnas.1115521109

Katz, R.W., Brown, B.G. 1992. Extreme events in a changing climate: variability is more important than averages. Climatic change 21, 289302.

Katz, R.W., Murphy, A.H. (Eds.) 1997. Economic Value of Weather and Climate Forecasts. Cambridge University Press.

Kelman, I. 2017. Linking disaster risk reduction, climate change, and the sustainable development goals. Disaster Prevention and Management: An International Journal 26, 254-258. https://doi.org/10.1108/DPM-02-2017-0043

Kelman, I., Gaillard, J.C., Mercer, J. 2015. Climate Change's Role in Disaster Risk Reduction's Future: Beyond Vulnerability and Resilience. 
International Journal of Disaster Risk Science 6, 21-27.

https://doi.org/10.1007/s13753-015-0038-5

Keohane, R.O., Victor, D.G. 2016. Cooperation and discord in global climate policy. Nature Climate Change 6, 570-575.

https://doi.org/10.1038/nclimate2937

Klotzbach, P.J., Bowen, S.G., Pielke Jr., R., Bell, M. 2018. Continental U.S. Hurricane Landfall Frequency and Associated Damage: Observations and Future Risks. Bulletin of the American Meteorological Society 99, 1359-1376. https://doi.org/10.1175/BAMS-D-17-0184.1

Knight, F. H. 1921. Risk, Uncertainty and Profit. University of Illinois at Urbana-Champaign's Academy for Entrepreneurial Leadership Historical Research Reference in Entrepreneurship. Available at SSRN: https://ssrn.com/abstract=1496192.

Knutti, R., Rogelj, J., Sedláček, J., Fischer, E.M. 2016. A scientific critique of the two-degree climate change target. Nature Geoscience 9, 13-18. https://doi.org/10.1038/ngeo2595

Konrad, K.A., Thum, M. 2014. The Role of Economic Policy in Climate Change Adaptation. CESifo Economic Studies 60, 32-61. https://doi.org/10.1093/cesifo/iftoo3

Kunkel, K.E., Andsager, K., Easterling, D.R. 1999a. Long-Term Trends in Extreme Precipitation Events over the Conterminous United States and Canada. Journal of Climate 12, 2515-2527.

https://doi.org/10.1175/15200442(1999)012<2515:LTTIEP>2.0.CO;2

Kunkel, K.E., Pielke Jr, R.A., Changnon, S.A. 1999b. Temporal Fluctuations in Weather and Climate Extremes That Cause Economic and Human Health Impacts: A Review. Bulletin of the American Meteorological Society 80, 1077-1098. https://doi.org/10.1175/15200477(1999)080<1077:TFIWAC >2.0.CO;2

Kutzbach, J., Bonan, G., Foley, J., Harrison, S.P. 1996. Vegetation and soil feedbacks on the response of the African monsoon to orbital forcing in the early to middle Holocene. Nature 384, 623-626. https://doi.org/10.1038/384623ao

Lafferty, W., Hovden, E. 2003. Environmental policy integration: towards an analytical framework. Environmental Politics 12, 1-22. https://doi.org/10.1080/09644010412331308254

Lempert, R.J. 2014. Embedding (some) benefit-cost concepts into decision support processes with deep uncertainty. Journal of Benefit-Cost Analysis 5, 487-514.

Lempert, R.J., Groves, D.G. 2010. Identifying and evaluating robust adaptive policy responses to climate change for water management agencies in the American west. Technological Forecasting and Social Change 77, 960-974. https://doi.org/10.1016/j.techfore.2010.04.007

Lempert, R.J., Popper, S.W., Bankes, S.C. 2003. Shaping the next one hundred years: new methods for quantitative, long-term policy analysis. RAND, Santa Monica, CA.

Li, J., Mullan, M., Helgeson, J. 2014. Improving the practice of economic analysis of climate change adaptation. Journal of Benefit-Cost Analysis 5, 445-467. 
Maier, H. R., Guillaume, J. H., van Delden, H., Riddell, G. A., Haasnoot, M., \& Kwakkel, J. H. 2016. An uncertain future, deep uncertainty, scenarios, robustness and adaptation: How do they fit together? Environmental Modelling \& Software 81, 154-164.

Mannakkara, S., \& Wilkinson, S. J. 2015. Supporting post-disaster social recovery to build back better. International Journal of Disaster Resilience in the Built Environment 6, 126-139.

Markowitz, H. 1952. Portfolio Selection. The Journal of Finance 7, 77-91.

Mas-Colell, A., Whinston, M.D., Green, J.R. 1995. Microeconomic Theory. Oxford University Press Inc., New York, Oxford.

Mendelsohn, R. 2012. The Economics of Adaptation Climate Change in Developing Countries. Climate Change Economics 03, 1250006. https://doi.org/10.1142/S2010007812500066

Mendelsohn, R. 2000. Efficient adaptation to climate change. Climatic Change 45, 583-600.

Mercer, J. 2010. Disaster risk reduction or climate change adaptation: Are we reinventing the wheel? Journal of International Development 22, 247-264. https://doi.org/10.1002/jid.1677

Mickwitz, P., Kivimaa, P. 2007. Evaluating Policy Integration: The Case of Policies for Environmentally Friendlier Technological Innovations. Evaluation 13, 68-86. https://doi.org/10.1177/1356389007073682

Milinski, M., Semmann, D., Krambeck, H.-J. 2002. Reputation helps solve the 'tragedy of the commons'. Nature 415, 424-426. https://doi.org/10.1038/415424a

Morss, R.E., Wilhelmi, O.V., Downton, M.W., Gruntfest, E. 2005. Flood Risk, Uncertainty, and Scientific Information for Decision Making: Lessons from an Interdisciplinary Project. Bulletin of the American Meteorological Society 86, 1593-1602. https://doi.org/10.1175/BAMS-86-11-1593

Najafi, B. 2017. Geostorm. Warner Bros. Pictures.

Neumayer, E., Barthel, F. 2011. Normalizing economic loss from natural disasters: A global analysis. Global Environmental Change 21, 13-24. https://doi.org/10.1016/j.gloenvcha.2010.10.004

Neumayer, E., Plümper, T., Barthel, F. 2014. The political economy of natural disaster damage. Global Environmental Change 24, 8-19. doi:10.1016/j.gloenvcha.2013.03.011

Nilsson, M., Persson, A. 2003. Framework for analysing environmental policy integration. Journal of Environmental Policy \& Planning 5, 333-359.

Nordhaus, W. 2015. Climate Clubs: Overcoming Free-riding in International Climate Policy. American Economic Review 105, 1339-1370. https://doi.org/10.1257/aer.15000001

Nordhaus, W. 1982. How Fast Should We Graze the Global Commons? The American Economic Review 72, 6.

Nunan, F., Campbell, A., Foster, E. 2012. Environmental Mainstreaming: The Organisational Challenges of Policy Integration. Public Administration and Development 32, 262-277. https://doi.org/10.1002/pad.1624

Nurmi, P., Perrels, A., Nurmi, V. 2013. Expected impacts and value of improvements in weather forecasting on the road transport sector. 
Meteorological Applications 20, 217-223.

https://doi.org/10.1002/met.1399

Nurmi, V. 2019. Essays in Environmental Cost-Benefit Analysis (Thesis). https://helda.helsinki.fi/handle/10138/301567.

Nyborg, K. 2014. Project evaluation with democratic decision-making: What does cost-benefit analysis really measure? Ecological Economics 106, 124-131. https://doi.org/10.1016/j.ecolecon.2014.07.009

Oberthür, S. 2009. Interplay management: enhancing environmental policy integration among international institutions. International Environmental Agreements: Politics, Law and Economics 9, 371-391. https://doi.org/10.1007/s10784-009-9109-7

O'Brien, G., O'Keefe, P., Rose, J., Wisner, B.,2006. Climate change and disaster management. Disasters 30, 64-80.

O’Brien, K. 2012. Global environmental change II: From adaptation to deliberate transformation. Progress in Human Geography 36, 667676. https://doi.org/10.1177/0309132511425767

Ogallo, L. 2010. The Mainstreaming of Climate Change and Variability Information into Planning and Policy Development for Africa. Procedia Environmental Sciences 1, 405-410. https://doi.org/10.1016/j.proenv.2010.09.028

Ostrom, E., Burger, J., Field, C.B., Norgaard, R.B., Policansky, D.,1999. Revisiting the Commons: Local Lessons, Global Challenges. Science 284, 278-282. https://doi.org/10.1126/science.284.5412.278

Otto, F. E., Wolski, P., Lehner, F., Tebaldi, C., Van Oldenborgh, G. J., Hogesteeger, S., ... \& New, M. 2018. Anthropogenic influence on the drivers of the Western Cape drought 2015-2017. Environmental Research Letters 13(12), 124010.

Peduzzi, P., Dao, H., Herold, C., Mouton, F. 2009. Assessing global exposure and vulnerability towards natural hazards: the Disaster Risk Index. Natural Hazards and Earth System Science 9, 1149-1159. https://doi.org/10.5194/nhess-9-1149-2009

Peng, S., Piao, S., Ciais, P., Friedlingstein, P., Ottle, C., Bréon, F.-M., Nan, H., Zhou, L., Myneni, R.B. 2012. Surface Urban Heat Island Across 419 Global Big Cities. Environmental Science and Technology 46, 696703. https://doi.org/10.1021/es2030438

Phillips, B.D. 2014. Qualitative Disaster Research. Oxford University Press.

Pielke Jr, R., Prins, G., Rayner, S., Sarewitz, D. 2007. Climate change 2007: Lifting the taboo on adaptation. Nature 445, 597.

Pielke Jr, R. 2019. Tracking progress on the economic costs of disasters under the indicators of the sustainable development goals. Environmental Hazards 18, 1-6. https://doi.org/10.1080/17477891.2018.1540343

Pielke Jr, R. 2005. Misdefining "climate change": consequences for science and action. Environmental Science \& Policy, Mitigation and Adaptation Strategies for Climate Change 8, 548-561. https://doi.org/10.1016/j.envsci.2005.06.013

Pielke Sr, R.A., Pitman, A., Niyogi, D., Mahmood, R., McAlpine, C., Hossain, F., Goldewijk, K.K., Nair, U., Betts, R., Fall, S., Reichstein, M., Kabat, P., de Noblet, N. 2011. Land use/land cover changes and climate: modeling analysis and observational evidence. Interdisciplinary 
Reviews: Climate Change 2, 828-850.

https://doi.org/10.1002/wcc.144

Pielke Sr, R.A. 2005. Land Use and Climate Change. Science 310, 1625-1626. https://doi.org/10.1126/science.1120529

Pigou, A.C. 1928. A Study in Public Finance. Macmillan and Co., Limited, London.

Pindyck, R.S. 2013. Climate Change Policy: What Do the Models Tell Us? Journal of Economic Literature 51, 860-872. https://doi.org/10.1257/jel.51.3.86o

Pratt, J.W. 1964. Risk Aversion in the Small and in the Large. Econometrica 32, 122-136. https://doi.org/10.2307/1913738

Ramanathan, V., Feng, Y. 2008. On avoiding dangerous anthropogenic interference with the climate system: Formidable challenges ahead. Proceedings of the National Academy of Sciences 105, 14245-14250. https://doi.org/10.1073/pnas.0803838105

Renn, O. 1998. Three decades of risk research: accomplishments and new challenges. Journal of Risk Research 1, 49-71. https://doi.org/10.1080/136698798377321

Rivera, C., \& Wamsler, C. 2014. Integrating climate change adaptation, disaster risk reduction and urban planning: A review of Nicaraguan policies and regulations. International Journal of Disaster Risk Reduction 7, 78-90. https://doi.org/10.1016/j.ijdrr.2013.12.008

Robson, C. 2002. Real World Research: A Resource for Social Scientists and Practitioner-Researchers, 2nd ed. Blackwell Publishing, Oxford, UK.

Rogelj, J., den Elzen, M., Höhne, N., Fransen, T., Fekete, H., Winkler, H., Schaeffer, R., Sha, F., Riahi, K., Meinshausen, M. 2016. Paris Agreement climate proposals need a boost to keep warming well below $2{ }^{\circ} \mathrm{C}$. Nature 534, 631-639. https://doi.org/10.1038/nature18307

Rosa, E.A. 1998. Metatheoretical foundations for post-normal risk. Journal of Risk Research 1, 15-44. https://doi.org/10.1080/136698798377303

Rosenfeld, D., Lohmann, U., Raga, G.B., O’Dowd, C.D., Kulmala, M., Fuzzi, S., Reissell, A., Andreae, M.O. 2008. Flood or Drought: How Do Aerosols Affect Precipitation? Science 321, 1309-1313. https://doi.org/10.1126/science.1160606

Sadovnik, A.R. 2007. Qualitative Research and Public Policy, in Handbook of Public Policy Analysis: Theory, Politics and Methods, Fischer F, Miller GJ and Sidney MS (eds), Boca Raton, FL: CRC Press.

Samuelson, P.A. 1954. The Pure Theory of Public Expenditure. The Review of Economics and Statistics 36, 387-389.

Sander, J., Eichner, J.F., Faust, E., Steuer, M. 2013. Rising variability in thunderstorm-related U.S. losses as a reflection of changes in largescale thunderstorm forcing. Weather, Climate, and Society 130409112301007. https://doi.org/10.1175/WCAS-D-12-00023.1

Savage, L. 1954. The Foundations of Statistics. Wiley, New York.

Schellnhuber, H.J. 2008. Global warming: Stop worrying, start panicking? Proceedings of the National Academy of Sciences 105, 14239-14240. https://doi.org/10.1073/pnas.0807331105

Schipper, E.L.F. 2009. Meeting at the crossroads?: Exploring the linkages between climate change adaptation and disaster risk reduction. 
Climate and Development 1, 16-30.

https://doi.org/10.3763/cdev.2009.0004

Smit, B., Burton, I., Klein, R.J.T., Wandel, J. 2000. An Anatomy of Adaptation to Climate Change and Variability. Climatic Change 45, 223-251. https://doi.org/10.1023/A:1005661622966

Smith, N., Brown, C., McDonald, G., Ayers, M., Kipp, R., Saunders, W. 2017. Challenges and Opportunities for Economic Evaluation of Disaster Risk Decisions. Economics of Disasters and Climate Change 1, 111120. https://doi.org/10.1007/s41885-017-0007-0

Solecki, W., Leichenko, R., O'Brien, K. 2011. Climate change adaptation strategies and disaster risk reduction in cities: connections, contentions, and synergies. Current Opinion in Environmental Sustainability 3, 135-141. https://doi.org/10.1016/j.cosust.2011.03.001

Stebbins, R.A. 2001. Exploratory Research in Social Sciences, Sage University Papers Series on Qualitative Research Methods 48. Sage, Thousand Oaks, CA.

Stephenson, D.B. 2008. Definition, diagnosis, and origin of extreme weather and climate events, in: Climate Extremes and Society. Cambridge University Press, Cambridge, p. 383.

Stern, N., Peters, S., Bakhshi, V., Bowen, A., Cameron, C., Catovsky, S., Crane, D., Cruickshank, S., Dietz, S., Edmondson, N., Garbett, S.-L., Hamid, L., Hoffman, G., Ingram, D., Jones, B., Patmore, N., Radcliffe, H., Sathiyarajah, R., Stock, M., Taylor, C., Vernon, T., Wanjie, H., Zenghelis, D. 2006. Stern Review: The Economics of Climate Change. HM Treasury, London.

Stocker, T.F., Qin, D., Plattner, G.-K. 2013. Technical Summary. In: Climate Change 2013: The Physical Science Basis. Contribution of Working Group I to the Fifth Assess-ment Report of the Intergovernmental Panel on Climate Change [Stocker, T.F., D. Qin, G.-K. Plattner, M. Tignor, S.K. Allen, J. Boschung, A. Nauels, Y. Xia, V. Bex and P.M. Midgley (eds.), in: WG1AR5_TS_FINAL.Pdf. Cambridge University Press, Cambridge, UK, and New York, NY, USA.

Stott, P. A., Christidis, N., Otto, F. E., Sun, Y., Vanderlinden, J. P., van Oldenborgh, G. J., ... \& Zwiers, F. W. 2016. Attribution of extreme weather and climate-related events. Wiley Interdisciplinary Reviews: Climate Change 7(1), 23-41.

Sussman, F., Grambsch, A., Li, J., Weaver, C.P. 2014a. Introduction to a special issue entitled Perspectives on Implementing Benefit-Cost Analysis in Climate Assessment. Journal of Benefit-Cost Analysis 5, 333-346.

Sussman, F., Weaver, C.P., Grambsch, A. 2014b. Challenges in applying the paradigm of welfare economics to climate change. Journal of BenefitCost Analysis 5, 347-376.

Swingland Ian R., Bettelheim Eric C., Grace John, Prance Ghillean T., Saunders Lindsay S., Pielke Roger A., Marland Gregg, Betts Richard A., Chase Thomas N., Eastman Joseph L., Niles John O., Niyogi Dev dutta S., Running Steven W. 2002. The influence of land-use change and landscape dynamics on the climate system: relevance to climatechange policy beyond the radiative effect of greenhouse gases. 
Philosophical Transactions of the Royal Society of London. Series A: Mathematical, Physical and Engineering Sciences 360, 1705-1719. https://doi.org/10.1098/rsta.2002.1027

Sähkömarkkinalaki 588/2013, 2013. Retrieved from http://www.finlex.fi/fi/laki/alkup/2013/20130588

Taleb, N. 2007. The Black Swan: The Impact of the Highly Improbable. Random House.

The World Bank and the United Nations. 2010. Natural Hazards, Unnatural Disasters: The Economics of Effective Prevention. The International Bank for Reconstruction and Development / The World Bank, Washington. ISBN: 978-0-8213-8050-5 eISBN: 978-0-8213-8141-0 DOI: $10.1596 / 978-0-8213-8050-5254$

Thorarinsdottir, T. L., Guttorp, P., Drews, M., Kaspersen, P. S., de Bruin, K. 2017. Sea level adaptation decisions under uncertainty. Water Resources Research 53(10), 8147-8163. https://doi.org/https://doi.org/10.1002/2016WR020354

Tol, R.S.J. 2005. Adaptation and mitigation: trade-offs in substance and methods. Environmental Science \& Policy 8, 572-578. https://doi.org/10.1016/j.envsci.2005.06.011

Tol, R. S. J. 2009. The Economic Effects of Climate Change. Journal of Economic Perspectives 23(2), 29-51.

Toth, F.L. 2008. Dealing with Surprises in Environmental Senarios, in: Alcamo, J. (Ed.), Environmental Futures: The Practice of Environmental Scenario Analysis, Developments in Integrated Environmental Assessment, Amsterdam, Oxford, p. 197.

Trenberth, K., Fasullo, J., Shepherd, T. 2015. Attribution of climate extreme events. Nature Climate Change 5, 725-730. https://doi.org/10.1038/nclimate2657

Tschakert, P., Dietrich, K.A. 2010. Anticipatory Learning for Climate Change Adaptation and Resilience. Ecology and Society 15(2), 11.

UNISDR (United Nations International Strategy for Disaster Reduction). 2017. National Disaster Risk Assessment - Governance System, Methodologies, and Use of Results (Words into Action Guidelines). UNISDR. https://www.unisdr.org/files/globalplatform/591f213cf2fbe52828_w ordsintoactionguideline.nationaldi.pdf

UNISDR (United Nations International Strategy for Disaster Reduction). 2015a. Sendai Framework for Disaster Risk Reduction 2015-2030. UNISDR, Geneva.

UNISDR (United Nations International Strategy for Disaster Reduction). 2015b. Making Development Sustainable: The Future of Disaster Risk Management. Global Assessment Report on Disaster Risk Reduction. Geneva, Switzerland: United Nations Office for Disaster Risk Reduction (UNISDR).

UNISDR (United Nations International Strategy for Disaster Reduction). 2005. Hyogo framework for Action 2005-2015: Building the Resilience of Nations and Communities to Disasters (Extract from the final report of the World Conference on Disaster Reduction (A/CONF.206/6)). UNISDR, Geneva, Switzerland. 
Urwin, K., Jordan, A. 2008. Does public policy support or undermine climate change adaptation? Exploring policy interplay across different scales of governance. Global Environmental Change 18(1), 180-191. https://doi.org/10.1016/j.gloenvcha.2007.08.002.

Walker, W. E., Marchau, V. A., Swanson, D.(2010. Addressing deep uncertainty using adaptive policies: Introduction to section 2. Technological Forecasting and Social Change 77(6), 917-923.

van Asselt, M.B.A., Rotmans, J. 2002. Uncertainty in Integrated Assessment Modelling. Climatic Change 54, 75-105. https://doi.org/10.1023/A:1015783803445

Venton, P., La Trobe, S.,2008. Linking climate change adaptation and disaster risk reduction (Technical Paper). Teddington, UK: Tearfund.

von Neumann, J., Morgenstern, O. 1944. Theory of Games and Economic Behavour. Princeton University Press, Princeton.

Weitzman, M. 2015. Internalizing the Climate Externality: Can a Uniform Price Commitment Help? Economics of Energy \& Environmental Policy 4, 37-50.

Weitzman, M.L. 2011. Fat-tailed uncertainty in the economics of catastrophic climate change. Review of Environmental Economics and Policy 5, 275-292.

Weitzman, M.L. 2009. The extreme uncertainty of extreme climate change: An overview and some implications. Harvard University, Boston.

Weitzman, M.L. 2001. Gamma discounting. The American Economic Review 91, 260-271.

White, G.F. 1945. Human adjustment to Floods - A geographical approach to the Flood Problem in the United States. Department of Geography Research Paper no. 29. The University of Chicago, Chicago.

Wisner, B. 2016. Vulnerability as Concept, Model, Metric, and Tool. The Oxford Research Encyclopedia, Natural Hazard Science. https://doi.org/10.1093/acrefore/9780199389407.013.25

Wisner, B., Blaikie, P., Cannon, T., \& Davis, I. 2003. At Risk: Natural Hazards, People's Vulnerability and Disasters. London: Routledge.

Wisner, B. 2017. "Build back better"? The challenge of Goma and beyond. International Journal of Disaster Risk Reduction, 26, 101-105.

World Meteorological Organization. 2008. Technical regulations: Basic Documents No. 2 Volume I - General Meteorological Standards and Recommended Practices. World Meteorological Organization, Geneva, Switzerland.

Wyatt, J.C. 2001. Management of explicit and tacit knowledge. Journal of the Royal Society of Medicine 94, 6-9. https://doi.org/10.1177/014107680109400102

Yanow, D. 2007. Qualitative-Interpretive Methods in Policy Research, in: Fischer, F., Miller, G., Sidney, M.S. (Eds.), Handbook of Public Policy Analysis: Theory, Politics, and Methods, Public Administration and Public Policy. CRC/Taylor \& Francis, Boca Raton, pp. 405-416. 
(C) 2016 Elsevier

Reprinted, with permission, from

International Journal of Disaster Risk Reduction 19: 461-473.

doi.org/10.1016/j.ijdrr.2016.07.010 



\title{
Defining climate change adaptation and disaster risk reduction policy integration: Evidence and recommendations from Zambia
}

\author{
Karoliina Pilli-Sihvola ${ }^{\mathrm{a}, \mathrm{b}, *}$, Senja Väätäinen-Chimpuku ${ }^{\mathrm{c}}$ \\ a Finnish Meteorological Institute, PO Box 503, FI-00101 Helsinki, Finland \\ ${ }^{\mathrm{b}}$ Department of Economics and Management, University of Helsinki, PO Box 27, 00014 Helsinki, Finland \\ ${ }^{c}$ Department of Environmental Sciences, University of Helsinki, PO Box 65, 00014 Helsinki, Finland
}

\section{A R T I C L E I N F O}

\section{Article history:}

Received 30 September 2015

Received in revised form

25 July 2016

Accepted 27 July 2016

Available online 28 July 2016

\begin{abstract}
A B S T R A C T
Due to the common objectives and similarities of Disaster Risk Reduction (DRR) and Climate Change Adaptation (CCA), their policy level integration has been gaining increasing attention. However, concise DRR and CCA definitions for policy integrate are yet to be provided. Drawing from the Environmental Policy Integration, this paper suggests definitions for the integration of CCA policy into DRR policy, further addressing the importance of its horizontal (inter-ministerial) and vertical (intra-ministerial) dimensions. The definitions were empirically examined in Zambia during the formulation and implementation of the DRR and CCA policies (at the horizontal dimension), and water management, agriculture and forestry policies (at the vertical dimension). Data were collected through semi-structured interviews and document review, and analysed within a policy integration cycle. Zambia is a good example of the increased understanding of the linkages of the two fields, and the role of governance in progressing the integration. Governance challenges and the historical burden have resulted in overlapping policy processes, as both policies incorporate the other field, and creates a threat of parallel national-level structures, thereby increasing potential inefficiencies in governance and policy implementation. The importance of developing a horizontal integration strategy prior to policy formulation processes to avoid the potential of inefficiencies became evident.
\end{abstract}

(c) 2016 Elsevier Ltd. All rights reserved.

\section{Introduction}

Climate change has brought a new dimension to hydro-meteorological processes by increasing the uncertainty related to weather and the climate, particularly extreme weather and climate events (climate extremes). Climate extremes with potentially negative impacts, i.e. natural hazards, may turn into disasters having impacts on people and their livelihoods by interacting with complex environmental, socio-economic and political interlinkages, which may be further affected by climate change $[28,29,58,59]$.

To tackle the impacts of natural hazards, there are two, until recently, separated fields: Disaster Risk Management (DRM) and Climate Change Adaptation (CCA). DRM can be divided into two related, but distinct components: Disaster Risk Reduction (DRR) and Disaster Management. DRR can be defined as a set of policies, objectives and measures implemented and taken before any disaster risk is apparent, whereas Disaster Management places focus

\footnotetext{
* Corresponding author at: Finnish Meteorological Institute, PO Box 503, FI00101 Helsinki, Finland.

E-mail addresses: karoliina.pilli-sihvola@fmi.fi,

senja.vaatainen@gmail.com (K. Pilli-Sihvola).
}

on the phase when the threat of disaster becomes evident. ${ }^{1}$ CCA can be defined as a process in natural systems to adjust to the actual climate and its effects, and a process in human systems to adjust to the actual and expected changing climate and its effects, "in order to moderate harm or exploit beneficial opportunities" [29].

Although DRM, particularly DRR approaches within it, and CCA have evolved from different backgrounds, approaches, time periods, and use partly different vocabulary, their borders are becoming increasingly blurred. On the one hand, the DRR community is introducing more anticipatory and forward-looking approaches in comparison to its earlier tendency to address existing risks, and is increasingly advocating for treatment of the causes of exposure and vulnerability rather than their consequences $[29,40,44,60]$. On the other hand, the understanding of CCA has shifted from "first-generation" approaches focusing on technological remedies for biophysical threats to "second-generation"

\footnotetext{
${ }^{1}$ In this paper, DRM is used when referring to the entire DRM policy of Zambia (e.g. Table 1), as the policy covers both DRR and Disaster Management. Otherwise DRR is used and DRR is the focus of this paper. DRR and DRM terms are not used interchangeably.
} 
adaptation that looks for solutions to decrease vulnerability created by complex dynamics of change in social-ecological systems $[3,5]$. DRR and CCA share many similar objectives as they both address exposure and underlying vulnerability, and aim at enhancing the resilience of affected people, assets and ecosystems $[11,29,35,55,58,74]$. Aspects of convergence include, for instance, poverty reduction due to its focus on vulnerability factors, sustainable management of natural resources for improved resilience and livelihood, and the integration of both aspects into sectorial policies and development [11,29,35,4,44,49,58,59,73,77].

The intertwined relations between DRR and CCA have prompted policy-level discussion and academic analysis on the importance of emphasizing the linkages of the two fields and on increasing their integration. Multilateral donors $[29,69-72,79]$ and nongovernmental organisations $[50,57,77]$ have noted the linkages of DRR and CCA and started incorporating them into strategies and plans in order to enhance sustainable development. Bilateral donors are slowly following the example of multilateral institutions in their attempts to integrate DRR and CCA within the development assistance and its coordination $[36,46]$.

The majority of the academic literature on DRR and CCA follows the historical separation of the two fields. However, case studies in various countries and contexts (e.g. urban/rural) regarding the policy integration process and outcome have been undertaken (e.g. $[9,11,4,54,55,60])$. Some studies have analysed the differences and similarities of DRR and CCA and the consequential hindrances facing integration $[30,44,58]$. The key benefits of integration, as categorised in Venton and La Trobe [77], are: a) reduced climaterelated losses through widespread DRR measures; b) increased efficiency of resource allocation (financial, human and natural) and c) enhanced effectiveness and sustainability of DRR and CCA approaches. Despite the common objectives, well recognized benefits and the similarity of DRR and CCA measures at the practical level [44], several challenges hinder the integration of DRR and CCA [4]. Gero et al. [11] identify fragmented policies from the global to local level as one of the key hindrances to integration; this is exacerbated by the lack of policy instruments supporting integration [55]. The hindrances are deepened due to knowledge mismatches; for example related to climate variability and climate change data $[4,44,55,60,65]$.

Two shortcomings are evident in the academic literature. First, it does not explicitly define the relationship of DRR and CCA within the policy integration, and its policy dimensions. Rivera and Wamsler [55, p. 79] see integration to be part of a mainstreaming process, "where mainstreaming involves modifications to specific, core operations in order to incorporate and indirectly act upon new aspects or topics". An emerging body of literature supports the integration of CCA policies and strategies into DRR due to CCA having the advantage of the long-term perspective. This is supported by, for instance, in $[30,35,44,55,58,59]$, or, as suggested by Rivera and Wamsler [55], DRR is the core operation, whereas CCA is the new aspect to be incorporated. Second, the case study literature focusing on integration provides hardly any systematic analytical approaches or frameworks (an exception being Gero et al. [11]) to understand the varying actors' perspectives on the need for, and practicalities of, integration.

The aim of this study is to increase the understanding of DRR and CCA policy integration as a means for effective and efficient management of weather and climate related risks. From an analytical perspective, this paper 1 ) defines integration at horizontal (inter-ministerial) and vertical (intra-ministerial) dimensions; 2) refines the policy integration cycle and 3 ) presents an analytical way to assess DRR and CCA policy integration in the policy formulation and implementation phases at the two policy dimensions (Sections 3 and 5). From an empirical perspective, this paper analyses 1) DRR and CCA policy integration through the analytical perspective in Zambia, with a focus on agriculture, forestry and water management sectors at the vertical dimension and 2) the actors' role and their views on integration to identify potential opportunities for, and challenges in the policy integration (Sections 4-6). Context, data and methods are described in Section 2. The focus on the policy level is taken because policies guide actions, and integration at the policy level could deepen the overall integration of DRR and CCA [29].

\section{Empirical context}

\subsection{Country context}

The Intergovernmental Panel on Climate Change (IPCC) defines climate risk as being a factor of the natural hazard, exposure and vulnerability of society [27,29]. On the one hand, Zambia, located in Southern Africa, has a relatively stable climate which is characterised most notably by the rainy season occurring typically from November to April. On the other hand, Zambia is characterised by widespread poverty and high income inequality [64]. The World Bank [64] classifies Zambia as a 'lower middle income' country, whereas the United Nations ranks it in the group of least developed countries [67]. The Global Climate Risk Index places Zambia to the lowest level of risk category, implying that Zambia has not experienced major weather-related disasters in the recent past. However, Notre Dame Global Adaptation Index [48] notes that "The high vulnerability score and low readiness score of Zambia [implies that it] has both a great need for investment and innovations to improve readiness and a great urgency for action. Zambia is the 45th most vulnerable country and the 65th least ready country [in the world to adapt to climate change]."

In Zambia, climate change is projected to increase the frequency of days and nights that are considered hot in the current climate and change the seasonal rainfall pattern by increasing precipitation and heavy rainfall events during the rainy season $[42,43]$. The three sectors in focus in this paper (agriculture, forestry and water management) all have a key role in Zambia's economy and society. Despite the low contribution of the agricultural sector to the gross domestic product (less than $10 \%$ in 2013), approximately 60\% of Zambians live in rural areas and agriculture provides livelihood for $50 \%$ of the population [64]. The agricultural sector is suffering, for instance, from high dependency on rain-fed agriculture and low production and productivity, particularly among subsistence farmers [14,23,7], and the dependency on rainfall makes the rural population highly vulnerable to variability and change in precipitation patterns [32]. Past natural hazards have led to major crop losses and failures [18]. Climatesmart-agriculture, "an approach to developing the technical, policy and investment conditions to achieve sustainable agricultural development for food security under climate change" [10, p. ix], has been promoted as a way to improve smallholder farmers response to the challenges posed by changing climate, and Arslan et al. [1] find that climate-smart-agriculture has potential in Zambia. Forests are a key natural resource to the rural population providing a safety net through, for example, food, energy and income supplies and help in water and soil conservation [24,61], are a key contributor in providing ecosystem-based DRR and CCA measures [53]. Between 1965-2005, the annual deforestation rate was estimated to be approximately $0.5-0.6 \%$ of total forest cover, resulting from a range of direct (e.g. agricultural extensification, charcoal production) and indirect (e.g. poverty, population growth, climate variability) drivers [78]. Without proper water resources management, climate change may threaten the country's renewable water resources, further challenging economic development [63].

Zambia is addressing the challenge of climate change by 


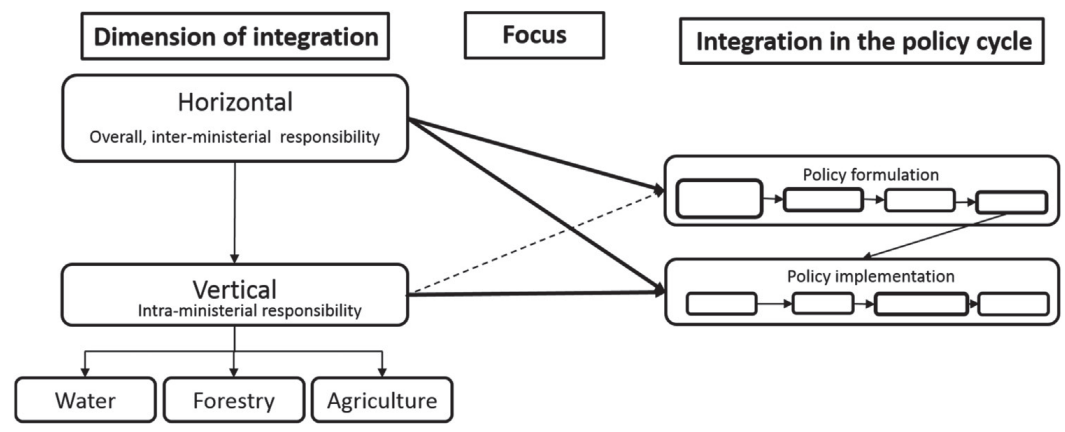

Fig. 1. The relationship between the dimensions of integration, the Policy Integration Cycle and the focus of the study.

piloting major climate resilience programmes. In 2010, as one of the first countries in the world, the World Bank funded Pilot Programme for Climate Resilience (PPCR) Phase I was initiated. It moved onto its second phase in $2013 .^{2}$ Zambia is also creating and renewing policies and institutional arrangements to guide and coordinate the approaches towards climate change and DRR.

Zambia was selected because all the studies on the linkages and integration of DRR and CCA policies, and the need for it, have been so far undertaken in Asia, the Pacific, and Central and South America [11,3,55], where natural hazards are more severe and frequent than in Zambia [37]. However, unless prominent vulnerabilities in Zambia are effectively addressed, the country is likely to experience an increasing risk of natural hazards due to its high level of vulnerability and low level of preparedness [48,62]. Therefore, Zambia provides an example of a context where the climate risk is mainly dictated by the societal vulnerability, and not the natural hazard, per se.

\subsection{Data collection}

\subsubsection{Semi-structured interviews}

To understand DRR and CCA integration in the policy formulation and implementation phases at horizontal and vertical dimensions (Fig. 1), and the role of actors involved and their views on the integration in Zambia, 21 semi-structured interviews [12] were undertaken with government bodies (11 interviews in 8 bodies), cooperating partners (2), civil society organisations (CSOs) (4) and other (4) (see the organisations interviewed in Appendix A). All the key government bodies responsible for the DRM and CCA policy at the horizontal level, and in the sectors chosen for the analysis at the vertical dimension, were interviewed. The main cooperating partners, the United Nations Development Programme (UNDP) and the World Food Programme (WFP) were interviewed as they spearhead the DRR and CCA activities within the UN Development Assistance Framework (UNDAF). The CSOs interviewed are all members of the Zambia Climate Change Network that represents the organisations focusing on the climate change and DRM-related processes. Cooperating donors in the agriculture, water management and forestry sectors, and two other non-governmental actors that participated in the climate change policy formulation were also interviewed.

Semi-structured interviews were necessary due to the in-depth nature of the analysis; the objective was not to merely analyse the integration in the policy documents but to focus on the actors'

\footnotetext{
${ }^{2}$ http://www.worldbank.org/projects/P121986/zambia-pilot-programme-cli mate-resilience-phase? lang=en

http://www.worldbank.org/projects/P127254/zambia-strengthening-climate-re silience-ppcr-phase-ii? lang=en
}

views on policy integration, and how integration may unfold in the policy documents and in the implementation phase in Zambia. The interviews with CSOs and other actors were used to add depth and to triangulate the information given by government bodies and cooperation partners. The interviewer followed the snowball technique to make sure that all key stakeholders were covered, and the interview round was terminated when the interview responses started to converge toward common answers. The interviews lasted approximately one hour and were transcribed verbatim. They were completed in July 2014, before the adoption of the Sendai Framework for Disaster Risk Reduction 2015-2030 [68], which has already spurred response in Africa. ${ }^{3}$

The interview guide was divided into policy formulation and implementation phases. The themes regarding the formulation phase were: 1 ) the responsibilities of the organisation regarding DRR and CCA; 2) knowledge of the terms and concepts in DRR and CCA and disaster occurrence in Zambia; 3 ) policies and legal frameworks that are guiding the work of the interviewee's organisation, and 4) how the organisation has participated in the formulation of the relevant policy documents. The themes regarding the implementation phase were: 1 ) the institutional arrangements and financial assistance toward achieving DRR and CCA policy objectives, and 2) practical examples of the integration of DRR and CCA occurring in Zambia.

\subsubsection{Documents}

The objectives of the study guided the choice of the complementary data (See Appendix B). All available CCA and DRR documents were analysed to determine the horizontal integration of CCA and DRR in the policy documents. Vertical integration in the chosen sectors was analysed though the existing or draft Acts of these sectors to screen possible CCA and DRR policy instruments and initiatives. The drafts of the National Policy on Climate Change (NPCC) and the national agricultural policy were received from government officials. No access was given to the DRM policy revision draft. Financial support for the horizontal and vertical policy implementation was analysed through the government budgets 2012-2014. Neither the NPCC nor the revised DRM Policy [13] had been adopted by the Cabinet of Ministers by the time the analysis was conducted.

\subsection{Analysis}

The documents and interviews were analysed with respect to four aspects: 1) if, and in which phase of the policy cycle, policy level integration was occurring; 2) dimension of the integration; 3 ) implementation instrument, project or programme and 4) the

\footnotetext{
${ }^{3}$ http://www.unisdr.org/archive/45168
} 
actor involved. The first aspect consists of the four stages in the formulation and four stages in the implementation phase, and challenges in the integration (Section 4). The second aspect consists of the dimension of the integration, and it was coded as 'horizontal' (overall CCA or DRM policy) or 'vertical' (within sectorial policies). The third aspect in terms of policy instruments was coded as 'Legislation' and further as 'Regulation' if relevant; 'Economic'; or 'Information' [76] and in terms of programmes as 'Ecosystem-based DRR or Adaptation' (Eco-DRR \& EbA) or 'climatesmart agriculture' [29]. The data were coded with $\mathrm{R}$ software package RQDA [26].

\section{Integration of disaster risk reduction and climate change adaptation within a policy cycle: definitions and framework}

\subsection{Defining disaster risk reduction and climate change adaptation policy integration}

Despite the increasing volume of literature on the integration of CCA into DRR policies, the term policy integration has not been explicitly defined in this context. Policy integration was first defined in Underdal [66], which was further utilised in the development of Environmental Policy Integration (EPI) [39]. EPI, by definition, sets environmental goals as the first priority when integrated into sectorial policies. In other policy areas, the idea of principled priority has been relaxed (e.g [31,45]).

Following the idea from the literature that CCA policy objectives should be integrated into DRR, and based on the policy integration definitions given in Lafferty and Hovden [39] and Mickwitz and Kivimaa [45], the integration of CCA into DRR policies can be defined as:

- The incorporation of CCA policy objectives into all stages of DRR/ DRM policy making;

- accompanied by an attempt to aggregate anticipated impacts of climate change into an overall evaluation of the DRR/DRM policy, and a commitment to minimise contradictions between CCA and DRR/DRM policies and implementation processes.

The objectives of CCA should be integrated in the DRR policy objectives, and not vice versa, as governmental DRR structures already exist in many countries (e.g. [2]) as well as the long-term experience of these government bodies in tackling with various kinds of hazards. If successfully integrated according to the definition, the perspectives of CCA policy and practice would bring in the much-needed long-term planning expertise into the already existing vulnerability reduction aims of the DRR policies and practices.

A further aspect of policy integration is its two dimensions. Firstly, horizontal integration, according to Lafferty and Hovden [39], "is the extent to which a central authority has developed a comprehensive cross-sectoral strategy for EPI". Following this idea, horizontal integration of DRR and CCA policies can be defined as the extent to which a central authority has developed a cross-sectorial strategy to integrate CCA and DRR policies. Secondly, vertical integration, defined as "the extent to which a particular governmental sector has adopted and sought to implement environmental objectives as central in the portfolio of objectives that the governmental body continuously pursues" [emphasis added] depicts the key feature of EPI, which is to give a principled priority of environmental objectives over sectorial policies [39]. However, it is not reasonable to assume that a principled priority should be given to the shared objectives of the CCA or DRR policies over the sectorial policies. Therefore, vertical integration of DRR and CCA policies can be defined as the extent to which a particular government sector has adopted and sought to implement the shared objectives of the CCA and DRR policy objectives in the portfolio of objectives that the governmental body continuously pursues. Following the distinction in economic theory [47], the definitions suggested here can be seen as normative; how things should be; whereas the following analysis is positive; how things are. The recommendations provided in this paper aim at narrowing the gap between the two.

Integration dimensions can be understood as dimensions in a governance 'landscape', where focus is placed on the role of 'governmental steering' [39, p. 12]. This implies an analytical focus on "strategies, plans, instruments and other initiatives" (i.e. governance) in the policy making. Vertical integration does not require that a horizontal integration process has already taken place, and vertical integration is often the dimension pursued more actively and achieved earlier due to an easier process [39]. The horizontal and vertical policy processes do not necessarily occur simultaneously or equally many times.

The analytical framework used is given in Fig. 1. To obtain an in-depth understanding of the integration of the CCA and DRR policies at the horizontal level and the integration of their shared objectives at the vertical level, a policy cycle framework was used as a heuristic device. Fig. 1 depicts the two policy dimensions and their relation to the policy cycle, which can be broadly decomposed into formulation and implementation phases. The policy cycle and its use in the empirical context is explained in detail in Section 3.2. To reflect the policy situation in Zambia (dotted arrow included only for illustrative purpose), where sectorial policies have already been adopted and are at the implementation phase, as opposed to the DRR part of the DRM policy and the NPCC, this paper analyses the on-going horizontal integration at the policy formulation phase, whereas the focus of the implementation phase in relation to policy integration is on both the horizontal and vertical dimension.

\subsection{Analytical framework for policy integration}

The generic form of the policy cycle shown in Fig. 1 has been further refined in Mickwitz and Kivimaa [45] to the policy integration cycle (presented in Fig. 2) to reflect stages where policy integration can take place. This is used as a heuristic framework to analyse the policy level integration of DRR and CCA in Zambia. The framework elaborates on the frameworks of Pollitt and Bouckaert [52] and Vedung [76] by specifically focusing on the stages in the policy cycle where integration can take place, assuming that it is wanted and beneficial. The definitions for the eight stages within the policy formulation and implementation phases analysed in this paper and the focus of this paper in each stage are provided in Table 1. The empirical focus on integration in different stages in the policy process, instead in the final DRM and CCA policy documents, was done because the process of DRR and CCA integration is at an early stage in Zambia, and final DRR and CCA policy outputs were not available during the data collection period.

The limitations of the policy cycle have been widely discussed in the policy literature, and alternative approaches have been developed and demonstrated. According to its critics it does not, for instance, accurately portray the complexity of real-world policy-making, as it decomposes the policy-making process into discrete sequential phases and further down into stages; it does not define policy goals or provide means to prioritise them; it neither explains or predicts actors' behaviour nor power relationships; does not have causal theory or testable hypotheses, and has never been turned into a theory in itself, e.g. $[6,33,56]$. However, despite this criticism, it has proved to be a useful conceptual tool and heuristic device, applied to analyse and understand the "everyday processes" of complex policy-making [33,34,52]. Although this 


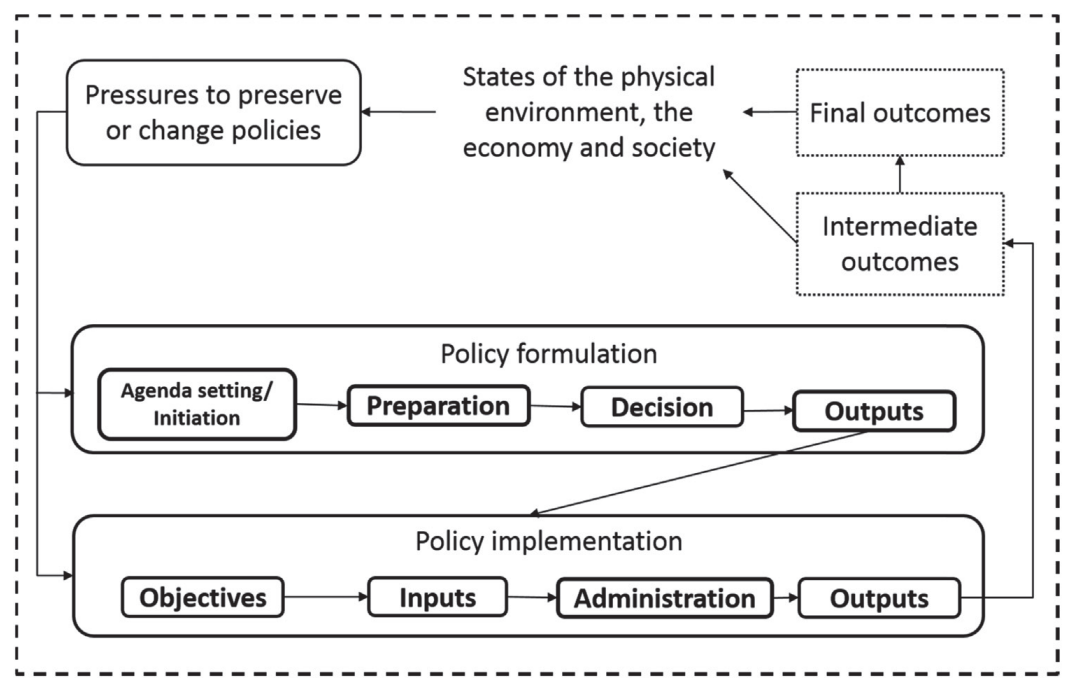

Fig. 2. The policy integration cycle used in the analysis (adopted from [45]).

Table 1

The stages of the policy cycle and the focus of analysis in Zambia.

\begin{tabular}{|c|c|c|c|}
\hline Phase & Stage & Definition & Focus of the analysis \\
\hline \multirow[t]{4}{*}{$\begin{array}{l}\text { Integration in Policy } \\
\text { formulation }\end{array}$} & $\begin{array}{l}\text { Agenda setting/ } \\
\text { initiation }\end{array}$ & $\begin{array}{l}\text { Public intervention starts when the problem is identified and } \\
\text { comes to the attention of political officials or governments } \\
{[25,76] \text {. }}\end{array}$ & $\begin{array}{l}\text { DRR and CCA integration in the agenda setting/ } \\
\text { initiation and preparation of the formulation of the } \\
\text { CCA and DRM policies. }\end{array}$ \\
\hline & Preparation & $\begin{array}{l}\text { A multi-purpose stage with potentially many actors to as- } \\
\text { sess e.g. the nature of the problem, options for action, } \\
\text { consequences and costs; ends with the presentation of } \\
\text { proposals for outcomes to be decided upon. [76] }\end{array}$ & \\
\hline & Decision & $\begin{array}{l}\text { A formal, authoritative, legitimating resolution which can be } \\
\text { made at different governmental levels. [76]. }\end{array}$ & $\begin{array}{l}\text { The state and actors of the decision on the ap- } \\
\text { proval of DRM and CCA policies and the implica- } \\
\text { tions for integration. }\end{array}$ \\
\hline & Outputs & $\begin{array}{l}\text { Outputs as policy documents, which are forward-looking } \\
\text { documents setting goals and priorities for the nation [ } 45] \text {. }\end{array}$ & $\begin{array}{l}\text { Potential integration in the DRM and CCA policy } \\
\text { documents under development. }\end{array}$ \\
\hline \multirow[t]{4}{*}{$\begin{array}{l}\text { Integration in Policy } \\
\text { implementation }\end{array}$} & Objectives & $\begin{array}{l}\text { The objectives of the policy instruments, such as regulation, } \\
\text { economic instruments and information, or programmes to } \\
\text { implement the policies [45]. }\end{array}$ & $\begin{array}{l}\text { Integration in the objectives of the DRR and CCA } \\
\text { policy instruments. }\end{array}$ \\
\hline & Inputs & $\begin{array}{l}\text { Resources, staff and buildings to implement measures to } \\
\text { reach the objectives [52] }\end{array}$ & $\begin{array}{l}\text { The government budget allocation and staff input } \\
\text { to coordinate the implementation of common DRR } \\
\text { and CCA policy objectives. }\end{array}$ \\
\hline & Administration & Conversion from inputs to outputs [76]. & $\begin{array}{l}\text { Integration in the institutional arrangements } \\
\text { which coordinate DRR and CCA policy } \\
\text { implementation. }\end{array}$ \\
\hline & Outputs & $\begin{array}{l}\text { The matters in the policy implementation and their potential } \\
\text { integration faced by the target groups, which are e.g. com- } \\
\text { panies, organisations or individuals [ } 45] \text {. These again feed } \\
\text { back to the revision of policies for the next cycle. }\end{array}$ & $\begin{array}{l}\text { The existence of government programmes to im- } \\
\text { plement the common objectives of DRR and CCA } \\
\text { policies. }\end{array}$ \\
\hline
\end{tabular}

paper does not focus on the policy process, per se, the policy cycle framework proposed in [45], with its specific focus on policy integration, provides a way to structure data collection and analysis in the empirical setting.

As this paper analyses policy integration in an on-going process of policy formulation and implementation, the intermediate (short-term outcomes, such as reduced number of flood damage and casualties due to improved policies) or final (long-term outcomes, such as increased level of child nutrition) outcomes, cannot yet be identified or analysed. Indeed, they often take years to realise. However, as Mickwitz and Kivimaa [45] state, it is crucial to remember that the goal of policy integration should not be to change bureaucracies but the real world, that is the states of the environment, economy and society. Assuming that increased integration of DRR and CCA policies is supported, this should be the main goal of the process also in this context.

This paper is not a retrospective evaluation on policy integration [76], but an assessment of ongoing policy integration using Zambia as an example within the wider discussion of DRR and CCA integration. As noted in Ishii and Langhelle [31] in relation to carbon capture and storage policy, the most appropriate level of integration cannot be judged a priori, but through successive iteration of policy processes and practices; and a higher level of integration can be achieved through a conscious integration process. 


\section{Integration of disaster risk reduction and climate change adaptation policies in Zambia}

This section analyses the current governance of DRR and CCA (horizontal) policies and sectorial (vertical) policies in relation to agriculture, water resources and forestry sectors, and if any integration of the common objectives of CCA and DRR is present. Despite that the DRR and CCA policies had not been adopted by the time data were collected and analysis undertaken, existing sectorial policy documents to guide implementation include aspects of CCA and DRR, and there are several CCA and DRR programmes on-going in Zambia. No direct quotes from the interviews have been provided due to the politically sensitive nature of the subject in Zambia; in the following a clear indication of the type of information source is provided.

\subsection{Integration at the horizontal dimension}

This subsection analyses the integration of DRR into the NPCC, and CCA into DRM policy in the formulation of these two policies. In practice, the formulation took place more or less simultaneously in 2013-2014.

\subsubsection{From initiation to preparation}

DRM in Zambia has been under the auspices of the vice president's office since 1994; the main governmental institution responsible for DRM is the Disaster Management and Mitigation Unit (DMMU). The Disaster Management Operations Manual, the National Disaster Management Act and the National Disaster Management Policy $[17,19,20]$ guide and support the implementation of disaster management programmes and activities in the country. A revised DRM policy had been under development since 2013, and the policy was adopted in June $2015^{4}$ [13]. The preparation for the DRM policy was coordinated by DMMU and supported by WFP.

CCA in Zambia was explicitly initiated in the National Adaptation Programme of Action (NAPA) [18]. The preparations for a governance framework for managing CCA was started in 2007 with policy formulation, creation of a National Climate Change Response Strategy [15,16] and drafting the NPCC. Between 2009-2012, this was overseen by the Climate Change Facilitation Unit, which handed over the responsibility to the interim Climate Change Secretariat, the current, temporary coordination structure for climate change in Zambia. The preparation was started by UNDP and was coordinated by the then Ministry of Tourism, Environment and Natural Resources (current Ministry of Land, Natural Resources and Environmental Protection).

Zambia has stated the need to combine and harmonize CCA and DRM legislation and has been contemplating different options for the institutional CCA and DRM arrangement (GRZ, n.d.) [23]. The incorporation of DRR aspects into the climate change policy documents is visible in the relevant documents starting from the National Climate Change Response Strategy [15]. In the first policy document to touch on this issue, the NAPA [18], DRR aspects can only be seen, for instance, in the statement that the "NAPA will complement the efforts of the government through the following: (1) contributing to the security of the vulnerable Zambians ...", whereas the National Climate Change Response Strategy from 2011 lists "Adaptation and Disaster Risk Reduction" as the first of its five pillars.

The United Nations Development Assistance Framework (20112015) has developed a Joint Programme on Climate Change and Disaster Risk Reduction for Zambia; initiated by the realisation

\footnotetext{
${ }^{4}$ This policy document was not available for this study.
}

that most disasters in Zambia are climate-related. Based on a stakeholder interview, this aspect was therefore taken further in the preparation of the NPCC and supported by the United Nations (UN). DMMU was actively involved in the preparation of the NPCC regarding the DRR component. According to the key actors for DRM policy formulation, the incorporation of CCA aspects in the DRM policy was initiated by a shift in the international focus of the DRM field, through the implementation of the Hyogo Framework for Action [73], and at the local level by the DMMU because of the realisation that climate change is exacerbating the hazards affecting the communities. The incorporation was also supported by the UN. The preparation involved consultation with sectorial stakeholders and CSOs; confirmed by the umbrella group for CSOs acting in climate change. However, according to the key governmental climate change actors, they were not aware of the DRM policy revision process. Thereby, parallel policy processes with integration taking place in both directions emerged at the beginning of the processes.

\subsubsection{Decision leading to output}

The draft NPCC and DRM policies were submitted to the cabinet of ministers concurrently in the spring 2014. The CCA and DRM policies were to be approved by the same committee in the cabinet of ministers. The committee is in a position to ensure that there are no contradictions between the policies, institutional structures (see Section 4.1.4) and implementation, which may be the output of the parallel policy processes. The policy outputs will depend on the decision taken in the parliament, and can be only analysed after the policies have been adopted. There are two potential outputs in terms of integration. The more likely output of the parallel preparation processes will be two separate policy documents: DRM policy and NPCC, which both address DRR and CCA issues, implying that two-way integration takes place.

\subsubsection{Objectives in the policy instruments}

In terms of regulatory instruments, no legislation exists that directly addresses CCA. A plan to develop a climate act focusing on the institutional CCA framework and mitigation exists. Two key governmental climate change actors noted that CCA does not require legislation per se, but it should be incorporated in the practices and mainstreamed into the legislation of sectors whilst renewing their acts.

The Disaster Management Act (2010) does not impose any direct regulation to implement DRR measures or explicitly mention climate-related risks or climate change. It gives the planning, coordination and monitoring mandate to DMMU to, inter alia, prevent and mitigate all potential disaster risks, and imposes a responsibility to DMMU to guide sectorial ministries and departments, the private sector, nongovernmental organisations, communities and individuals on how to assess, prevent and reduce the risk of disasters. It also establishes a National Disaster Relief Trust Fund. The objectives of the existing DRM legislation point towards the common objectives of DRR and CCA. In terms of information instruments for CCA, capacity building and awareness raising in the communities was raised as an important, yet poorly utilised policy instrument by all governmental actors on DRR and CCA, and CSOs. Zambia has formulated the National Climate Change Advocacy, Communication and Awareness Strategy, and its implementation is the first measure identified in the draft NPCC to increase climate change awareness.

The Disaster Management Act involves two information instruments: a multi-hazard Early Warning System and an electronic disaster management database which should be "electronically accessible to any person free of charge". The responsibility of these is given to DMMU, and the database, titled ZEPRIS, has been 
developed. ${ }^{5}$ These instruments, if implemented successfully, contribute to the common objectives of CCA and DRR by increasing the resilience of society and communities to natural hazards.

\subsubsection{Achieving the objectives}

In terms of the inputs to achieve the objectives of the policy instruments, an important aspect is the monetary allocation for the common objectives of CCA and DRR. Tracking government budget allocations for CCA and DRR is challenging due to, for instance, the lack of clear definition for DRR and CCA activities $[41,51]$ and the discrepancy in planned government budgets and actual spending [80]. However, it is important to understand the planned budget allocation on CCA and DRR, as it gives an indication of the priorities of the governments. ${ }^{6}$

DMMU is the only government authority receiving a substantial budgetary input for DRR and CCA, as the interim Climate Change Secretariat is mostly funded through the Pilot Programme for Climate Resilience. However, the inflation adjusted allocation for preparedness, response and mitigation for DMMU in 2012-2014 has been decreasing. In 2012-2013, an activity titled 'Facilitate the Development of Disaster Risk Reduction (DRR)' was allocated less than $0.5 \%$ of the preparedness, response and mitigation budget resources, but in 2014, an activity titled 'Climate Change Adaptation Projects' was allocated over $5 \%$ of the same budget. These show a sign of CCA and DRR integration and changing preferences at the policy level. DMMU has a district level disaster fund implemented in 20 out of the 72 districts in Zambia. A plan to develop disaster funds at provincial and national level also exist. The experience in the 20 districts has shown the challenges regarding financing of the activities. The interim Climate Change Secretariat plans to create a climate fund for implementation of climate change activities.

Due to donor-driven projects, several CCA programmes are already initiated or taking place, with additional contribution from the government. Early warning systems and dissemination of meteorological information were seen as key implementation measures among the key donors, both DRR and CCA actors in the government, agricultural sector and CSOs, and the Zambian Meteorological Department saw this as its main role in CCA and DRR. The Pilot Programme for Climate Resilience has also initiated an early warning system project. This is also reflected in increased government budget allocations for the procurement of new and upgrading of existing meteorological stations and the development of supporting infrastructure. However, the current, and particularly the development of future integrated implementation measures, which could address the long-term climatological changes, such as climateproofing new infrastructure to consider future climate, suffer from the lack of research on future climate. The government budget does not allocate any funding for climatological research. Furthermore, basic research on situational and vulnerability analyses in relation to CCA and DRR was seen to require much more emphasis and funding by the governmental actors, compared to the current situation. DMMU has received funding for information dissemination through ZEPRIS from the government and ZEPRIS is currently under further development to disseminate disaster and climate change information online.

Administration of DRM and CCA policies takes place both at national and local levels. National level coordination is a key issue in terms of funding streams and general efficiency of the implementation; however, actual implementation of measures and programmes is mostly performed at the local level. Zambia is aiming at increasing the decentralization of government

${ }^{5}$ Zambia Emergency Preparedness and Response Information System (ZEPRIS) http://www.zepris.dmmu-ovp.gov.zm/

${ }^{6}$ The ZCCN has undertaken budget tracking in 2011 and 2013; however, due to the lack of inflation adjustment, the results of these studies are not reported here. structures, and the importance of the governance of local level implementation was suggested by the governmental climate change actors and one CSO. At the district level, development coordinating committees are the main focal point for all government issues. The focal point for climate change is the district development coordinating committee, as this enables the mainstreaming of CCA into all various sectors. DMMU structure at the district level are disaster management coordination committees, which are a sub-committee of the development coordinating committees.

Currently, the government is providing financial input for CCA by allocating staff from ministries as part-time attachments to the interim Climate Change Secretariat, with a positive effect of having staff report back to their ministries, and from 2014 by allocating budget funding for other operating expenses [75]. However, as noted by an actor with experience of the interim Climate Change Secretariat, the participation is not their priority, and staff commitments may vary. This situation may potentially change if an independent National Climate Change Development Council is founded, as full time staff would be employed. As noted by the actor responsible for the NPCC and one CSO, funding available for climate change is currently plentiful, but a legal mandate and long-term government contribution is needed to keep government structures sustainable. Due to historical examples, the CSO was critical regarding the creation of new government structures.

All key climate change actors (governmental and CSO) noted that the dominating issue in the NPCC will be the form of the institutional framework. Three options for the national level institutional CCA arrangement have been considered: 1) the National Climate Change Development Council; 2) aggregation at the Ministry of Finance and Planning, the Cabinet or the Vice President's office; or 3) to keep climate change under the Ministry of Lands, Natural Resources and Environment Protection and DRM under the Vice President's office and DMMU [23]. Currently, it is suggested that a National Climate Change Development Council is established to coordinate the implementation of both CCA and mitigation, whereas DMMU will be the implementation body of the DRM policy. However, due to government hesitation and financial constraints to create new government structures, the less likely, yet possible output is that the mandate of CCA is given to an existing government authority. DMMU was seen suitable as it is the only government agency with experience on undertaking hazard and vulnerability analyses. DMMU has also gained experience through hosting the existing DRM platform, the Zambia Vulnerability Assessment Committee, which has representation from the government, donors and civil society. Furthermore, DMMU has been the only actor doing community-level weather related vulnerability assessments, and it is also the only government department with structures and representation down to the village level, which provides opportunity for effective implementation of DRR and CCA activities.

The concern regarding the operationalization and implementation of the climate change and DRM policies due to the overlaps in the NPCC and DRM policies was raised by the climate change actors. Despite that DMMU is eager to expand its mandate to cover DRR objectives and would be a natural candidate for coordinating CCA efforts, governmental climate change actors noted that the challenge with DMMU being responsible for long term climate change issues is the traditional mandate and practice of DMMU only responding to emergencies. This was also visible in the allocation of resources in the budget, as the majority of the budget was targeted towards emergency response activities. The hesitation to give CCA coordination to DMMU has historical roots as, according to a donor actor, DMMU was not given the responsibility of the CCA coordination at the creation of the Pilot Programme on Climate Change because no climate change issues 
existed in the DRM legislation at the time. This led to the development of the interim Climate Change Secretariat.

\subsection{Integration at the vertical dimension}

Vertical integration ensures that the sectorial legislation, policy instruments and programmes are screened for the common objectives of CCA and DRR to decrease the likelihood of goal-conflicts between DRR, CCA and sectorial policies. The most relevant information regarding the DRR and CCA objectives in the existing legislation in agriculture, forestry and water management sectors is given in Appendix $C$ to understand the current level of vertical integration in the sectors. The analysis shows that in terms of regulatory instruments, some vertical, indirect integration exists. The agricultural sector is governed by several Acts. None of them directly address DRR or CCA; however, the Food Reserve Act [22] covers disaster management. The Forests Act [21] is rather dated, and direct vertical integration in the regulation does not take place. However, indirectly the aim of using forests in a sustainable manner contributes towards the common objectives of CCA and DRR. The Water Resources Management Act [16] is the most advanced in terms of vertical integration. The purpose and the guiding principles of the Act are clearly linked to the shared objectives of CCA (explicitly mentioned) and DRR. Furthermore, the Water Resources Management Authority shall explicitly consider impacts and adaptation to climate change in its operations, thereby bringing in the long-term aspect to the legislation.

The only economic instruments to touch upon the common objectives of DRR and CCA exist in the agriculture sector. According to Kuteya [38], the majority of the agricultural policy objectives are implemented through the agricultural budget. A slight majority (52\% in 2014) of the agricultural budget is directed to so called Poverty Reduction Programmes, out of which $96 \%$ is targeted to Fertilizer and Input Support Programme (32\%) and Food Strategic Reserves (64\%). The budget share for these increased by $3 \%$ points from 2013 to 2014, despite several reported problems in these programmes. Donor support for Social Cash Transfer programmes (see [8] for evaluated benefits in Malawi) within the agricultural budget increased by 169\% from 2013 to 2014 [38].

In agricultural sector in 2014, small scale funding had been allocated to the agricultural budget for 'climate change projects in land husbandry', 'small scale irrigation projects', 'construction of irrigation streams under climate change' and 'climate-smart agriculture'; thereby indicating an increased awareness of the need for CCA in the sector. Capacity building, awareness raising and science centres on climate change were allocated resources in all years. In the forestry budget, deforestation has been mentioned in 2013 in terms of assessment and monitoring, and in 2014, when the UN REDD programme ${ }^{7}$ was allocated resources.

Climate smart agriculture has been heavily promoted by the cooperating partners and the civil society, and in 2014, a small contribution from the government was added to the national budget. However, there is no indication of changing government preferences in terms of diverting away from the Fertilizer and Input Support Programme and Food Strategic Reserves programmes towards government initiatives for less climate-sensitive agriculture, such as heavier support for small scale irrigation and other climate-smart agriculture measures.

In terms of the inputs invested in the sectors in 2012 and 2013, the water resources management sector was allocated funding for monitoring the impacts of climate change, and in 2013 money was also allocated for integration of climate change in water resources monitoring. In 2014, no explicit climate change allocation was

\footnotetext{
${ }^{7}$ http://www.un-redd.org/
}

made. Water management actors noted that, despite the importance of water resources, there is a lack of research and knowledge on the quantity and availability of fresh water.

Intra-ministerial coordination for climate change has been established through climate change focal points, which still exists, at least, in the Ministry of Agriculture. The interim Climate Change Secretariat plans to sharpen its operation manual in order to clarify the interaction of the secretariat and the ministries. No similar structure has so far been created for DRR issues.

\section{Discussion}

The general direction for integration in the academic literature, in the EU European Commission 2013 [81] and further explicitly defined in this paper, is that climate change policy goals should be integrated into DRR policy goals. Zambia is a clear example of how international discussion and local level experiences have increased the understanding of the linkages between DRR and CCA, and initiated their policy integration. Integration is, however, not unproblematic. Our analysis shows that the historical structures of the governing bodies and the different political interests have created a situation where a systematic and strategic approach to integration is lacking. Although the benefits of integration are known among key actors, the status quo is yet to be challenged, leading to parallel, inter-linked and potentially inefficient governance systems. With respect to the role of integration in the policy cycle, parallel policy integration was initiated at the beginning of the policy process, either initiated or supported by the UN. Zambia is, thereby, an addition to the list of countries where the governance related challenges of the integration of DRR and CCA are visible.

Addressing integrated DRR and CCA efforts with vulnerability reduction as the main focus should be a priority in Zambia, as it is a country where vulnerability is the main contributing factor to disaster risk. DMMU or the interim Climate Change Secretariat do not yet have the main responsibility for this due to the need of multisectoral development expertise of vulnerability reduction, however, it should be the first priority of DRR activities in Zambia. Despite the "theoretical" advantages of DMMU extending its mandate toward DRR, CCA and development work compared to the current focus on disaster management, it is challenging due to DMMU's lack of institutional capacity and legitimacy amongst key actors. This would avoid the creation of parallel structures, but would require a shift in the focus of DMMU operations, including the expertise needed in the daily work. If further integration already taking place is promoted, the renewal of the DRM policies and legislation to incorporate CCA as a long-term perspective would direct the development of the CCA and DRR fields towards the definition suggested in Section 3.1. Furthermore, integration has potential at the district level, where the impacts of natural hazards are felt and measures implemented.

CCA has been incorporated into the water resources management sector; it is becoming an emerging issue in the agricultural sector, whilst the focus of the forestry sector is more on mitigation of climate change. However, a thorough vertical integration requires a systematic analysis of the vulnerabilities and role of natural hazards and climate change in the vulnerability, and a plan on how to avoid goal-conflicts between different policies. A thorough analysis would be a costly, yet highly beneficial effort to ensure sustainable development under climate change. It would also guide the inter-ministerial harmonization after which the DRR and CCA policies, and their objectives, would be in a position to bring efficient coordination to the vertical dimension, improving currently lacking policy coherence.

The majority of the CCA and DRR programmes have been initiated and maintained by donor funding, which may create a 
serious challenge for their long-term sustainability. This is evident in the lack of government and donor contributions for ECo-DRR \& EbA programmes, which require a long-term commitment if they are to deliver positive outcomes.

To complement existing literature on DRR and CCA policy integration, this paper explicitly defines DRR and CCA policy integration and introduces and uses a heuristic framework originating from the environmental policy field. Such an approach provides a systematic way to analyse policy integration and to understand varying perspectives on the need for, and practicalities of, integration. Interviews gave an understanding of the underlying reasons and justification for the challenges in the policy-level integration and helped to obtain actors' views on the capacity, appropriateness, and implications of CCA becoming part of the remit of the DMMU.

On a practical level, the analysis provides insights that can assist not only the government and cooperation partners, but other countries in the Southern African Development Community (SADC) region in their efforts to effectively and efficiently manage weather and climate related risks. Similar parallel DRR and CCA structures are found in almost all SADC countries, the only exception being Mozambique [2]. Furthermore, Tall et al. [62] note that "Knowledge and data collection on the climate disaster management institutional frameworks and policy contexts of African countries remain generally quite poor". The practical implications of the analysis in the SADC region are further supported by the notable similarities between most of the 15 SADC countries (excluding South Africa, Botswana and Mauritania) in terms of their vulnerability and readiness to adapt to climate change [48].

The policy cycle has been criticised for being an over-simplification of the nature of real world complex policy-making processes. The cyclical, often chaotic nature of policy making implies that there is no beginning or end, and all the stages of policy making take place in a complex environment. This was the case in Zambia, as the DRR and CCA policy processes were initiated before the current policy document preparation stages began. Therefore, several versions of our integration policy cycle framework were considered to reflect the situation. Eventually, the policy integration cycle presented in Mickwitz and Kivimaa [45] was refined with clear definitions and an analytical focus for each stage. This proved to be a useful heuristic tool structure the interview guide and analysis. The semi-structured interviews provided insights into the policy making challenges, which would not have been possible by document analysis alone. Although the interviews were beneficial, the 'true' explanation for incorporating both CCA into the DRM policy and DRR into CCA policy and the power relationships at stake were more difficult to obtain. Furthermore, analysing the holistic policy context, including the pressure to preserve or change policies, would require a different approach.

Following Lafferty and Hovden [39], further research should identify a set of indicators to define the specific extent of horizontal and vertical CCA and DRR integration. The original indicators for EPI developed in [39] can be used as the starting point for indicators in DRR and CCA integration. As this study was undertaken whilst the CCA and DRR policy integration was in the making, further research would be required to analyse the final extent of integration, and the implications of the parallel policy outcomes and the potential inefficiencies. Other sectors at the vertical dimension, for instance energy or public works sectors, would provide additional insight and more compelling evidence for the (inadequate) vertical integration. This study did not address the integration of DRR and CCA objectives into economic or social development policies in Zambia. This should not be forgotten, as the full benefits of the CCA and DRR integration process are achieved only if the objectives of CCA and DRR are incorporated to all sectorial and development policies [29,30,35,36].

\section{Conclusion and recommendations}

Climate change, as one of the components increasing the risk landscape, poses challenges to societies and governments, particularly in situations where existing, historical disaster risks are not effectively and efficiently managed. This will require reshuffling of government structures, and increasing integration of DRR and CCA, both at horizontal and vertical levels of governance. This is not a simple task, however, and as shown in this paper, major challenges include the fact that while the international community is struggling in breaking the historical separation of the two fields in its guidance and financial support, also at the national level the existing government structures face reservation regarding their capacities and legitimacy to support the process of integration. Furthermore, sectorial governance demonstrates inadequate commitment and capacity toward integration. To overcome these obstacles, recommendations for national level governmental stakeholders related to horizontal and vertical integration and implantation are provided. Due to the similarities of the SADC countries, recommendations may be particularly relevant for other SADC countries.

Our first recommendation is to develop a horizontal CCA and DRR integration strategy for the policy formulation and implementation phases to avoid the creation of overlapping policies and to identify the responsibilities of different stakeholders; as a longterm goal a single CCA and DRR policy should be developed. In Zambia, it would have been beneficial if a horizontal integration strategy had been developed in an open manner involving all relevant stakeholders prior to the policy formulation and revision processes. However, even after the possible adoption of the current parallel policies, a horizontal integration and implementation strategy should be created in order to avoid problems related to the potential parallel structures. The strategy should guide the coordination of CCA and DRR processes at national and local levels.

At this point, as the policy process is at the decision stage, two possibilities exist. To avoid the creation of parallel, overlapping structures and to guide governance from national to community level if parallel institutional structures are established, a) the legal mandate of DMMU regarding its role in disaster management, DRR and CCA should be (re-)defined ; b) a legal status to the National Climate Change Development Council should be set; and c) a platform for inter-ministerial and agency communication should be established. If parallel institutional structures are not established, the authority and mandate to develop and implement CCA and DRR policies and measures should be given to an agency or government body with the best potential expertise and capacity to coordinate CCA and DRR matters within the national development goals from the national to the village level; and a platform for inter-ministerial and representation within the chosen agency or government body should also be established.

Our second recommendation is to develop a strategy for the vertical integration of CCA and DRR policy objectives to avoid potential goal-conflicts between the objectives of CCA and DRR and sectorial development policies, strategies and policy implementation instruments and to guide sectorial policy formulation and implementation. The impacts of natural hazards and climate change, and the importance of CCA and DRR for natural resources and economic sectors should be analysed, and the priorities between these and development objectives need to be defined. Existing and future sectorial legislation should be screened to ensure that potential goal-conflicts are minimised. Intra-ministerial communication structures to communicate CCA and DRR issues within sectors should be developed.

Our third recommendation is to establish clear, research-based guidelines on integrated DRR and CCA policy implementation and ensure long-term resources. To address the knowledge gap on 
climate change and its impacts, and to increase the development and implementation of integrated DRR and CCA instruments, a) basic climate change research should be funded; b) the capacity of DMMU to undertake situational and vulnerability analyses which incorporate natural hazards and climate change aspects should be built, and c) instruments to build the capacity and conceptual understanding of CCA and DRR at all governance levels should developed and implemented.

Last, to increase the long-term sustainability of policy implementation, a) strategies to decrease reliance on external project funding should be created, b) coordination and collaboration platforms for natural resource management sectors to improve the development and implementation of CCA and DRR measures should be developed, and c) possibilities and potential benefits of Eco-DRR \& EbA measures and increased resources for sustainable forest management in hazard-prone areas should be analysed.

\section{Contributions and acknowledgments}

Karoliina Pilli-Sihvola coded and analysed the data, deepened the theoretical contribution and the preliminary analysis and wrote the manuscript. Senja Väätäinen-Chimpuku provided the initial theoretical and empirical research idea, data collection, preliminary analysis and provided comments throughout the writing process. The authors have contributed equally to the paper.

This study was funded by the Academy of Finland through FICCA SAFE-MET (no: 264058 ) project. The authors would like to thank all interviewees, the two reviewers whose comments substantially improved the manuscript, and David Lazarevic, Katri Huutoniemi, Heikki Tuomenvirta, Sirkku Juhola, Ephraim Mwepya Shitima, and Ari Venäläinen for their comments on the manuscript.

\section{Appendix A. Stakeholders (category and alphabetical order)}

\section{Government}

Climate Change Secretariat

Disaster Management and Mitigation Unit (DMMU)

Forestry Department

Ministry of Agriculture

Ministry of Finance and Planning

Ministry of Land, Natural Resources and Environmental Protection

Ministry of Mines, Energy and Water Development/Department of Water Affairs

The Water Resources Management Authority

Zambia Meteorological Department

\section{Cooperating partners}

Deutsche Gesellschaft für Internationale Zusammenarbeit (GIZ) GmbH

The Embassy of Finland

United Nations Development Programme

Deutsche World Food Programme (WFP)

\section{Civil Society Organisations (CSOs)}

Green Living Movement

OXFAM

World Wildlife Fund of Zambia

Zambia Climate Change Network

\section{Other}

African Carbon Credit Exchange

Centre for Energy, Environment and Engineering Zambia

\section{Appendix B. Policy documents}

\section{CCA and DRR documents}

National Adaptation Plan of Action 2007

National Climate Change Response Strategy 2011 (final draft)

National Policy on Climate Change 2012 (final draft)

National Disaster Management Policy 2005

Disaster Management Act 2010

Revised Draft Disaster Management Operations Manual 2013

National Meteorological Policy 2013

2010 Comprehensive Vulnerability Assessment and Analysis Survey 


\section{Sectorial documents}

National Agricultural Policy 2013 (final draft)

National Forest Policy 2014 (final draft)

The Water Resources Management Act 2014

\section{General Government Documents}

- Revised Sixth National Development Plan 2013-2016 (stake-

holder draft from 2013)

Appendix C. DRR and CCA in the existing legislation in the agriculture, water resources management and forestry sectors

\begin{tabular}{llll}
\hline $\begin{array}{l}\text { Legislative } \\
\text { document }\end{array}$ & Principles referring to DRR and CCA & DRR & CCA \\
\hline
\end{tabular}

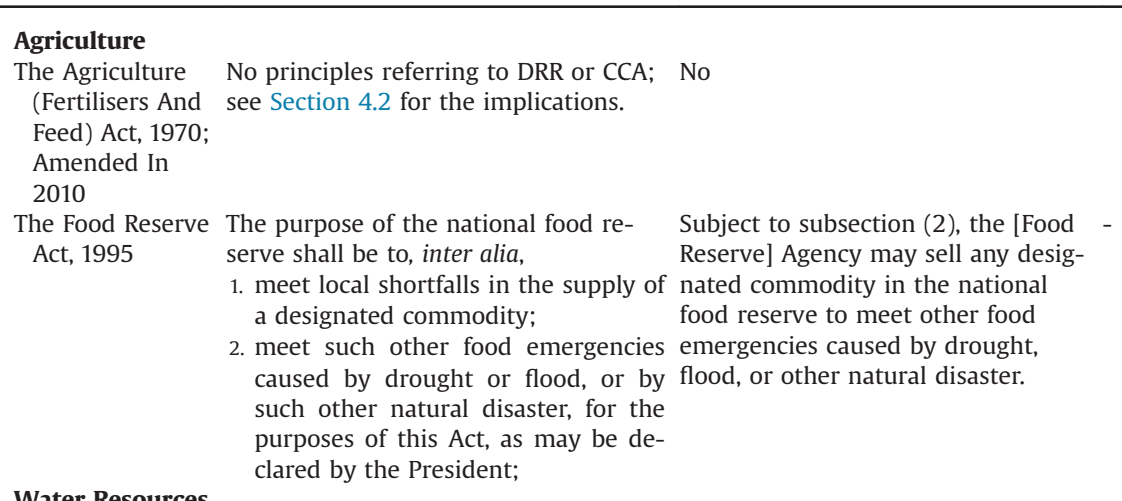

\section{Water Resources}

The Water Man- water is a basic human need and as agement Act, such domestic and non-commercial 2011

\section{Forestry}

The Forests Act, No principles referring to DRR or CCA; 1999 needs shall enjoy priority of allocation use; water resources shall be managed in such a manner as will help combat malaria and other waterborne diseases in order to ensure access to safe water; efforts to create wealth shall be reflected in all decisions made in relation to the use of water water resources management and planning shall contribute to the eradication of hunger and poverty and this shall be reflected in all decisions made in relation to the use of water, in particular, the right to use water for domestic and noncommercial purposes shall not be under any permit or attract, any charge for its use the management, development and utilisation of water resources shall take into account climate change adaptation
WRMA [Water Resources Management Agency] shall ensure, in collaboration with the Ministries responsible for community development, finance, commerce, agriculture, fisheries and livestock, youth and child development and disaster management and mitigation, that the management and planning of water resources contributes to the eradication of hunger and poverty;
WRMA [Water Resources Management Agency] shall conserve, preserve and protect the environment, in particular, wetlands, quarries, dambos, marshlands and headwaters and take into account climate change and the challenges posed by climate change by - [ $\mathrm{sev}$ eral measures listed]

\section{References}

[1] A. Arslan, N. McCarthy, L. Lipper, S. Asfaw, A. Cattaneo, M. Kokwe, Climate smart agriculture? Assessing the adaptation implications in Zambia, J. Agric. Econ. 66 (2015) 753-780, http://dx.doi.org/10.1111/1477-9552.12107.

[2] P. Becker, M. Abrahamsson, M. Hagelsteen, Parallel structures for disaster risk reduction and climate change adaptation in Southern Africa, Jámbá: J. Disaster
Risk Stud. (2013) 5, http://dx.doi.org/10.4102/jamba.v5i2.68.

[3] J. Birkmann, et al., Addressing the challenge: recommendations and quality criteria for linking disaster, in: J. Birkmann, G. Tetzlaff, K.-O. Zentel (Eds.), Risk Reduction and Adaptation to Climate Change, DKKV Publication Series 38. DKKV, Bonn, 2009, p. 59. 
[4] J. Birkmann, K. von Teichman, Integrating disaster risk reduction and climate change adaptation: key challenges-scales, knowledge, and norms, Sustain Sci. 5 (2010) 171-184, http://dx.doi.org/10.1007/s11625-010-0108-y.

[5] E. Boyd, R.J. Cornforth, Building climate resilience: lessons of early warning in Africa, in: S.C. Moser, M.T. Boykoff (Eds.), Successful Adaptation to Climate Change - Linking Science and Policy in a Rapidly Changing World, Routledge, 2013, pp. 201-219.

[6] P. Bridgman, G. Davis, What use is a policy cycle? Plenty, if the aim is clear, Aust. J. Public Adm. 62 (2003) 98-102.

[7] A. Chapoto, L.M. Chabala, O.N. Lungu, A long history of low productivity In Zambia: Is it time to do away with blanket recommendations? (IAPRI Working Paper No. 110.) (2016), Indaba Agricultural Policy Research Institute, Lusaka, Zambia.

[8] K. Covarrubias, B. Davis, P. Winters, From protection to production: productive impacts of the Malawi Social Cash Transfer scheme, J. Dev. Eff. 4 (2012) 50-77, http://dx.doi.org/10.1080/19439342.2011.641995.

[9] E.G. de Leon, J. Pittock, Integrating climate change adaptation and climaterelated disaster risk-reduction policy in developing countries: a case study in the Philippines, Clim. Dev. (2016) 1-8, http://dx.doi.org/10.1080/ 17565529.2016.1174659.

[10] FAO (Food and Agriculture Organisation of the United Nations), 2013. Climate Smart Agriculture - Sourcebook.

[11] A. Gero, K. Méheux, D. Dominey-Howes, Integrating disaster risk reduction and climate change adaptation in the Pacific, Clim. Dev. 3 (2011) 310-327, http://dx.doi.org/10.1080/17565529.2011.624791.

[12] B. Gillham, Research Interviewing: The Range of Techniques, McGraw-Hill International, 2005.

[13] GRZ (Government of the Republic of Zambia), 2015. National Disaster Management Policy.

[14] GRZ (Government of the Republic of Zambia), 2014. The Revised Sixth National Development Plan 2013-2016.

[15] GRZ (Government of the Republic of Zambia), 2011a. National Climate Change Response Strategy (NCCRS).

[16] GRZ (Government of the Republic of Zambia), 2011b. The Water Resources Management Act.

[17] GRZ (Government of the Republic of Zambia), 2010. The Disaster Management Act.

[18] GRZ (Government of the Republic of Zambia), 2007. Formulation of The National Adaptation Programme of Action on Climate Change (NAPA).

[19] GRZ (Government of the Republic of Zambia), 2005a. National Disaster Management Policy.

[20] GRZ (Government of the Republic of Zambia), 2005b. Disaster Management Operations Manual.

[21] GRZ (Government of the Republic of Zambia), 1999. The Forests Act.

[22] GRZ (Government of the Republic of Zambia), 1995. The Food Reserve Act.

[23] GRZ (Government of the Republic of Zambia), n.d. Maintaining a Programmatic Approach to the PPCR.

[24] GRZ (Government of the Republic of Zambia), FAO (Food and Agriculture Organisation of the United Nations), 2009. National Medium Term Priority Framework 2009-2013. Lusaka.

[25] M. Howlett, M. Ramesh, Studying Public Policy : Policy Cycles and Policy Subsystems, Oxford University Press,, Toronto, New York, NY, 1995.

[26] Huang, R., 2014. RQDA: R-based Qualitative Data Analysis. R package version $0.2-7$.

[27] IPCC, Climate Change 2014: Impacts, Adaptation, and Vulnerability. Contribution of Working Group II to the Fifth Assessment Report of the Intergovernmental Panel on Climate Change, Cambridge University Press, Cambridge, United Kingdom and New York, NY, USA, 2014.

[28] IPCC, 2013. Summary for Policymakers, in: Climate Change 2013: The Physical Science Basis. Contribution of Working Group I to the Fifth Assessment Report of the Intergovernmental Panel on Climate Change. Cambridge, United Kingdom and New York, NY, USA.

[29] IPCC, Managing the Risks of Extreme Events and Disasters to Advance Climate Change Adaptation: A Special Report of Working Groups I and II of the Intergovernmental Panel on Climate Change, Cambridge University Press, Cambridge, UK, and New York, NY, USA, 2012.

[30] P. Ireland, Climate change adaptation and disaster risk reduction: Contested spaces and emerging opportunities in development theory and practice, Clim. Dev. 2 (2010) 332-345, http://dx.doi.org/10.3763/cdev.2010.0053.

[31] A. Ishii, O. Langhelle, Toward policy integration: assessing carbon capture and storage policies in Japan and Norway, Glob. Environ. Change, Spec. Issue Polit. Policy Carbon Capture Storage 21 (2011) 358-367, http://dx.doi.org/10.1016/j. gloenvcha.2011.02.005.

[32] S. Jain, 2007. An empirical economic assessment of impacts of climate change on agriculture in Zambia. World Bank Policy Research Working Paper.

[33] W. Jann, K. Wegrich, Theories of the policy cycle, in: F. Fischer, G.J. Miller, M. S. Sidney (Eds.), Handbook of Public Policy Analysis: Theory, Politics, and Methods, Public Administration and Public Policy, CRC/Taylor \& Francis, Boca Raton, 2007, p. 642.

[34] A. Jordan, A. Lenschow, Environmental policy integration: a state of the art review, Environ. Policy Gov. 20 (2010) 147-158, http://dx.doi.org/10.1002/ eet.539.

[35] I. Kelman, J.C. Gaillard, J. Mercer, Climate change's role in disaster risk reduction's future: beyond vulnerability and resilience, Int. J. Disaster Risk Sci. 6 (2015) 21-27, http://dx.doi.org/10.1007/s13753-015-0038-5.

[36] R.J.T. Klein, S.E.H. Eriksen, L.O. Næss, A. Hammill, T.M. Tanner, C. Robledo, K.
L. O'Brien, Portfolio Screening to Support the Mainstreaming of Adaptation to Climate Change into Development Assistance, Climatic Change 84 (1) (2007) 23-44, http://dx.doi.org/10.1007/s10584-007-9268-x.

[37] S. Kreft, L., Junghans, D., Eckstein, U., Hagen, 2014. Global Climate Risk Index 2015 - Who Suffers Most From Extreme Weather Events? Weather-related Loss Events in 2013 an 1994 to 2013. Germanwatch Nord-Süd Initiative e.V., Bonn.

[38] A. Kuteya, 2013. Analysis of the 2014 Zambia's Agricultural Sector Budget.

[39] W. Lafferty, E. Hovden, Environmental policy integration: towards an analytical framework, Environ. Polit. 12 (2003) 1-22, http://dx.doi.org/10.1080/ 09644010412331308254.

[40] S.B. Manyena, E. Mavhura, C. Muzenda, E. Mabaso, Disaster risk reduction legislations: is there a move from events to processes? Glob. Environ. Change 23 (2013) 1786-1794, http://dx.doi.org/10.1016/j.gloenvcha.2013.07.027.

[41] H. McGray, A., Hammill, R., Bradley, 2007. Weathering the storm - options for framing adaptation and development. World Resources Institute, Washington DC.

[42] C. McSweeney, G. Lizcano, M. New, X. Lu, The UNDP climate change country profiles-improving the accessibility of observed and projected climate information for studies of climate change in developing countries, Bull. Am. Meteorol. Soc. 91 (2010) 157-166, http://dx.doi.org/10.1175/2009BAMS2826.1.

[43] G.A. Meehl, C. Covey, K.E. Taylor, T. Delworth, R.J. Stouffer, M. Latif, B. McAvaney, J.F.B. Mitchell, The WCRP CMIP3 multimodel dataset: a new era in climate change research, Bull. Am. Meteorol. Soc. 88 (2007) 1383-1394, http://dx.doi.org/10.1175/BAMS-88-9-1383.

[44] J. Mercer, Disaster risk reduction or climate change adaptation: are we reinventing the wheel? J. Int. Dev. 22 (2010) 247-264, http://dx.doi.org/10.1002/ jid.1677.

[45] P. Mickwitz, P. Kivimaa, Evaluating policy integration: the case of policies for environmentally friendlier technological innovations, Evaluation 13 (2007) 68-86, http://dx.doi.org/10.1177/1356389007073682.

[46] T. Mitchell, M., van Aalst, P., Silva Villanueva, 2010. Assessing Progress on Integrating Disaster Risk Reduction and Climate Change Adaptation in Development Processes.

[47] R.A. Musgrave, The Theory of Public Finance: a Study in Public Economy, McGraw-Hill, New York, 1959.

[48] ND-GAIN (University of Notre Dame Global Adaptation Index), n.d. ND-GAIN Index [WWW Document]. URL 〈http://index.gain.org/〉 (accessed 8.9.2015).

[49] G. O'Brien, P. O'Keefe, J. Rose, B. Wisner, Climate change and disaster management, Disasters 30 (2006) 64-80.

[50] Oxfam, 2010. Integrating disaster Risk Reduction and Climate Change Adaptation in the Philippines, in: Proceedings from the Roundtable Discussion, "A Sharing of Theory and Practice on DRR-CCA Work", Held on 13-14 April 2010, Quezon City, Philippines.

[51] A. Peterson Carvalho, P. Terpstra, Tracking adaptation finance - an approach for civil society organizations to improve accountability for climate change adaptation, Oxfam America Inc. and World Resources Institute, 2015.

[52] C. Pollitt, G. Bouckaert, Public Management Reform: A Comparative Analysis, 2nd edition, Oxford University Press Inc., New York, 2004.

[53] F.G. Renaud, K., Sudmeier-Rieux, M., Estrella, (Eds.), 2013. The Role of Ecosystems in Disaster Risk Reduction. United Nations University Press.

[54] C. Rivera, Integrating climate change adaptation into disaster risk reduction in urban contexts: perceptions and practice, PLoS Curr. 6 (2014), doi:10.1371/ currents.dis.7bfa59d37f7f59abc238462d53fbb41f.

[55] C. Rivera, C. Wamsler, Integrating climate change adaptation, disaster risk reduction and urban planning: a review of Nicaraguan policies and regulations, Int. J. Disaster Risk Reduct. 7 (2014) 78-90, http://dx.doi.org/10.1016/j ijdrr.2013.12.008.

[56] Theories of the Policy Process, in: P.A. Sabatier (Ed.), Second edition, 2nd edition,Westview Press, Boulder, Colorado, 2007.

[57] Save the Children, 2013. Practitioner Guidelines on the Integration of Disaster Risk Reduction and Climate Change Adaptation into Sector-Based Programs.

[58] E.L.F. Schipper, Meeting at the crossroads? Exploring the linkages between climate change adaptation and disaster risk reduction, Clim. Dev. 1 (2009) 16-30, http://dx.doi.org/10.3763/cdev.2009.0004.

[59] L. Schipper, M. Pelling, Disaster risk, climate change and international development: scope for, and challenges to, integration, Disasters 30 (2006) 19-38.

[60] W. Solecki, R. Leichenko, K. O'Brien, Climate change adaptation strategies and disaster risk reduction in cities: connections, contentions, and synergies, Curr. Opin. Environ. Sustain. 3 (2011) 135-141, http://dx.doi.org/10.1016/j. cosust.2011.03.001.

[61] O.A. Somorin, Climate impacts, forest-dependent rural livelihoods and adaptation strategies in Africa: a review, Afr. J. Environ. Sci. Technol. 4 (2010) 903-912.

[62] A. Tall, A.G. Patt, S. Fritz, Reducing vulnerability to hydro-meteorological extremes in Africa. A qualitative assessment of national climate disaster management policies: accounting for heterogeneity, Weather Clim. Extrem. 1 (2013) 4-16, http://dx.doi.org/10.1016/j.wace.2013.07.007.

[63] The World Bank, 2009. Zambia - Managing water for sustainable growth and poverty reduction: a country water resources assistance strategy for Zambia (Other Infrastructure Study No. 52963).

[64] The World Bank, n.d. World Development Indicators [WWW Document]. URL 〈http://data.worldbank.org/country/zambia〉 (accessed 8.9.2015).

[65] F. Thomalla, T. Downing, E. Spanger-Siegfried, H. Guoyi, J. Rockström, Reducing hazard vulnerability: towards a common approach between disaster risk reduction and climate adaptation, Disasters 30 (2006) 39-48. 
[66] A. Underdal, Integrated Marine Policy: What? Why? How? Mar. Policy 4 (1980) 159-169, http://dx.doi.org/10.1016/0308-597X(80)90051-2.

[67] UNDP (United Nations Development Programme), n.d. Human Development Reports - Data [WWW Document]. URL 〈http://hdr.undp.org/en/data (accessed 8.9.2015).

[68] UNISDR (United Nations International Strategy for Disaster Reduction), 2015. Sendai Framework for Disaster Risk Reduction 2015-2030. UNISDR, Geneva

[69] UNISDR (United Nations International Strategy for Disaster Reduction), 2011 Effective Measures to Build Resilience in Africa to Adapt to Climate Change (Briefing Note No. 4). UNISDR, Geneva.

[70] UNISDR (United Nations International Strategy for Disaster Reduction), 2010 Strengthening Climate Change Adaptation through Effective Disaster Risk Reduction (Briefing Note No. 3). UNISDR, Geneva.

[71] UNISDR (United Nations International Strategy for Disaster Reduction), 2009 Adaptation to Climate Change by Reducing Disaster Risks: Country Practices and Lessons (Briefing Note No. 2). UNISDR, Geneva.

[72] UNISDR (United Nations International Strategy for Disaster Reduction), 2008. Climate Change and Disaster Risk Reduction (Briefing Note No. 1). UNISDR, Geneva.

[73] UNISDR (United Nations International Strategy for Disaster Reduction), 2005. Hyogo framework for Action 2005-2015: Building the Resilience of Nations and Communities to Disasters (Extract from the final report of the World Conference on Disaster Reduction (A/CONF.206/6)). UNISDR, Geneva,
Switzerland.

[74] United Nations Framework Convention on Climate Change (UNFCCC), 2008. Integrating Practices, Tools and Systems for Climate Risk Assessment and Management and Strategies for Disaster Risk Reduction into National Policies and Programmes (Technical Paper No. FCCC/TP/2008/4). Geneva.

[75] J. van Rooij, The coordination of climate finance in Zambia, Overseas Development Institute, London, 2014.

[76] E.O. Vedung, Public Policy and Program Evaluation, Transaction Publishers, New Bruswick, N.J., 2000.

[77] P. Venton, S., La Trobe, 2008. Linking climate change adaptation and disaster risk reduction (Technical Paper). Tearfund, Teddington, UK.

[78] R. Vinya, S. Syampungani, E.C. Kasumu, C. Monde, R. Kasubika, Preliminary Study on the Drivers of Deforestation and Potential for REDD + in Zambia ( $A$ consultancy report prepared for the Forestry Department and FAO under the national UN-REDD + Programme), Ministry of Lands \& Natural Resources, Lusaka, Zambia, 2012.

[79] World Bank, Building resilience : integrating climate and disaster risk into development. Lessons from World Bank Group Experience, The World Bank, Washington D.C, 2013.

[80] ZCCN (Zambia Climate Change Network), 2011. 2010 National Budget Allocation and Expenditure Tracking in Relation to Climate Change. Lusaka, Zambia. [81] An EU Strategy on adaptation to climate change COM(2013) 216 final. 



\section{(C) 2018 Elsevier}

Reprinted, with permission, from

International Journal of Disaster Risk Reduction 31: 1266-1275.

doi.org/10.1016/j.ijdrr.2017.12.004 



\title{
Adaptation by the least vulnerable: Managing climate and disaster risks in Finland
}

\author{
Karoliina Pilli-Sihvola $^{\mathrm{a}, \mathrm{b}, *}$, Atte Harjanne ${ }^{\mathrm{a}, \mathrm{c}}$, Riina Haavisto ${ }^{\mathrm{a}}$ \\ a Finnish Meteorological Institute, P.O. Box 503, FI-00101 Helsinki, Finland \\ ${ }^{\mathrm{b}}$ University of Helsinki, Faculty of Agriculture and Forestry, Helsinki, Finland \\ c Aalto University School of Business, P.O. Box 21210, FI-00076 Aalto, Finland
}

\section{A R T I C L E I N F O}

\section{Keywords:}

Adaptation

Climate change

Disaster risk reduction

Finland

Governance

Welfare state

\begin{abstract}
A B S T R A C T
Disaster risk reduction (DRR) and climate change adaptation (CCA) literature has traditionally focused on the countries and regions hit hardest by natural hazards. In this paper, we take a different perspective by turning our eyes upon Finland, a Nordic welfare state and a low vulnerability and exposure society. We analyse and discuss how well the existing DRR and CCA approaches reflect the perspective of the least vulnerable countries and whether the current ways of determining vulnerability and exposure neglect some risks or hinder the seizing opportunities brought by climate change.

This paper is based on data gathered in a survey, interviews and workshops in two research projects which analysed weather and climate related risks in Finland. We conclude that disaster risk assessments need to be contingent and account for social and economic contexts. In an institutionally well-functioning welfare society, vulnerability assessments should emphasize relative changes in perceived social trends and social cohesion. Exposure should not be limited to direct geographical or physical exposure to local natural hazards. Successful opportunity identification can help improve DRR at home and abroad. In general, the role of political systems and culture as enabling factors for DRR and CCA need further study.
\end{abstract}

\section{Introduction}

"An ounce of prevention is worth a pound of cure."

The words attributed to Benjamin Franklin are as relevant today as they were in the 18th century; the complex and interlinked risk landscape that the modern world faces requires holistic, comprehensive approaches to reduce and manage these risks. Disaster risk related to weather and climate is one of the many risks faced by communities, societies and states. The climate is changing, exposing people to its impacts across the globe [37]. To make matters worse, this development takes place in a world which has by no means dealt with the natural hazards and disasters of the current climate (see e.g. [10]). As indicated by Franklin, and shown in many, although not in all cases, there is even economic rationale to act prior to the occurrence of major impacts $[4,76]$. This requires effective and efficient governance; i.e. policies and measures, and in many cases, transformative changes in societies to reduce the impacts of natural hazards and the changing climate.

Traditionally, the literature on disaster risk reduction (DRR) and climate change adaptation (CCA) has focused on the places hit hardest by weather and climate. This is no surprise, as it is only natural that the most relevant context for studying DRR or CCA are those where natural forces create disasters or where CCA challenges have already arisen. For example, in the articles published in the International Journal of Disaster Risk Reduction, the ten most frequently analysed countries comprise over half of all the country specific studies ${ }^{1}$; and none of the countries are European. Furthermore, in many studies, focus is placed on local or regional cases, and the role of national, state level governance is excluded or overlooked.

How, then, do DRR and CCA look from the perspective of a country that has not suffered any large-scale disasters triggered by natural hazards in the recent past, yet is constantly adapting to its challenging weather and climate conditions? What does adaptation entail when undertaken by the 'least vulnerable'? In this paper, we present an exploratory case on DRR and CCA in Finland; an EU Member State that is

\footnotetext{
* Corresponding author at: Finnish Meteorological Institute, P.O. Box 503, FI-00101 Helsinki, Finland.

E-mail address: karoliina.pilli-sihvola@fmi.fi (K. Pilli-Sihvola).

${ }^{1}$ We assessed all the articles on IJDRR Volumes 1-21 (for 21 up to 21 December 2016 as it was still in Progress) and identified 379 country mentions in titles or abstracts. 212 were about the top ten of India, United States, New Zealand, Bangladesh, Australia, Japan, Pakistan, Indonesia, China, Thailand and the Philippines.
} 
wealthy and stable ${ }^{2}$; has well-functioning governance structures; has a small population of 5.5 million people [79]; exhibits strong Nordic welfare state structures $[20,59]$; is not located in a hazard-prone area; and has a comprehensive approach to societal security. Finland can be seen as an example of a country where post-World War II development has also been a story of successful adaptation to climatic extremes and, so far, to climate change. This is confirmed by international indicatorbased country comparisons on vulnerabilities. Samson et al. [73], Standard \& Poor's [78] and Notre Dame Global Adaptation Initiative [56] all rank Finland among the countries least vulnerable to climate change.

Even though Finland does not face major natural hazards, such as cyclones or major flooding, the country has not always been immune to disasters triggered by weather and climate. In 1866-1868, an estimated $8 \%$ of the Finnish population perished in a famine triggered partially by adverse weather [92]. Strict public regulation, societal progress and major investments in ensuring that all vital societal functions work in exceptional situations have resulted in a country where natural hazards do not turn into disasters, and where climate change may actually bring beneficial opportunities if successfully harnessed [60].

The aim of the paper is two-fold:

1) to describe the Finnish model and the role of governance and society for DRR and CCA; and

2) to analyse and problematize the existing frameworks that guide-or are designed to guide-the theoretical and practical fields of DRR related natural hazards and CCA through the findings from the case description.

This paper is not the first to analyse the role of societal structures and governance in DRR and CCA. For instance, Alexander and Davis [2] suggest five factors that constitute as 'the elephant in the room' in DRR publications and gatherings: the human right to hazard information; explosive population growth, corruption, how people are placed at risk by the actions of governments; and gender discrimination. This is complemented in the Global Assessment Report on Disaster Risk Reduction 2015 ([86], p.254) as follows: "The governance of disaster risk is never autonomous from the quality of governance in general. Strengthening the quality of overall governance is therefore critical to strengthening the governance of disaster risk". However; Nordic countries, where the level of societal progress is high and rather equal among citizens, and the relative disaster impacts are low, are often forgotten in the literature. Alexander and Davis [2] discuss the importance of governance for donors and international agencies in development context, and UNISDR [86] focuses on countries with major disaster losses. Adaptation deficit [9] describes the lack of adaptation capacity that many low-income countries face in front of climate change due to political, institutional and technological reasons (e.g. $[8,18,23]$ )

We argue that there is value in bringing a new perspective in the discussion by analysing DRR and CCA in Finland for two reasons: First, the current literature covers a seemingly narrow geographical scope. Second, analysing DRR and CCA from a fresh perspective, by presenting a success story, can reveal novel thoughts on DRR and CCA and help to further improve the concepts. The implications of the Nordic structures to the disaster risk management and resilience are also explored in Pursiainen [65] and van Well et al. [89] in this issue.

The role of national level-and in the European Union (EU) supranational level-governance is crucial in DRR and CCA. Over the past decades in Europe, disasters and climate change have been politically addressed through various policy initiatives and extensively studied in EU-funded research programmes. The Union Civil Protection Mechanism (UCPM) from 2013 [14], The Floods directive [15] and the EU CCA strategy from 2013 [13] are all EU-level policies which aim at

\footnotetext{
${ }^{2}$ http://fundforpeace.org/fsi/ [Accessed 8.12.2017].
}

improving Member States' prevention and preparedness for extreme hydro-meteorological events and climate change. For instance, the UCPM requires all Member States to undertake national risk assessments every three years; the Floods directive requires the creation of flood hazard and risk maps; and the CCA strategy encourages all Member States to develop national CCA strategies, which has been accomplished by nearly all member states by 2017 [16].

Thorough research and strategy work on CCA has, however, also been pointed out as a potential source for complacency. Indeed, even if CCA strategies are in place and sectoral impacts are known, it does not guarantee that they result in effective adaptive policies or actions [57]. Integration of CCA into other policies and practices-so called mainstreaming - is considered a necessary enabler for effective adaptation to climate change [17]. Biesroek et al. [6] argue that institutional challenges can hinder CCA in Europe and more recently, Eisenack et al. [17] argue that such barriers are still retarding CCA efforts.

Despite mostly overlapping goals and measures, DRR and CCA are for the most part two distinct governance and research fields $[63,7,77,84]$. This is also the case in Finland, and therefore, we consider it both justified and useful to review DRR and CCA hand in hand but as distinct policy and governance processes. Section 2 describes our research design and methods and Section 3 describes the case study context; the social and physical characteristics and our findings about the DRR and CCA processes. In Section 4 we discuss the implications of the case to the frameworks used within DRR and CCA. Section 5 provides concluding remarks.

\section{Research design}

\subsection{Key frameworks and concepts}

Two parallel, yet partly overlapping risk frameworks are typically used in the disaster and climate literature to explain the weather and climate risks faced by communities and societies.

The Intergovernmental Panel on Climate Change [36,37] conceptualizes disaster risk as determined by vulnerability, exposure and weather and climate events, or more broadly natural hazards. Vulnerability refers to the propensity to be adversely affected by the hazards, exposure is the presence of people, livelihoods, resources, environmental services or any other assets of value in places that can be affected, and weather and climate events or natural hazards are the physical phenomena that can be potentially dangerous or harmful.

A more comprehensive model to understand weather and climate risk is the so-called Pressure-and-Release (PAR) model described in Wisner et al. [94]; which, similarly to the framework in IPCC $[37,36]$, presents vulnerability as a component in disaster risk, yet describes vulnerability as consisting of three parts: root causes, dynamic pressures and unsafe conditions. Wisner et al. [94] focus on least developed countries in their examples of PAR as a practical analytical tool; however, Rauken and Kelman [68] use the model to analyse the root causes behind river flood risk in Norway. They find that the political system; distribution of power and responsibilities, and the economic system with a focus on economic growth without addressing the flood risk are the root causes behind river flood risk.

As noted by e.g. [1, p. 21], the concept of vulnerability "cannot be separated from the social and cultural conditions under which it exists"; any indicators of vulnerability, and thus risks need to be contingent and take into account the social and economic context of the unit of analysis. One very particular context to study risks and vulnerabilities is the welfare state system, which, according to Esping-Andersen [19] historically has aimed at equal opportunities to individuals and eliminating social risks across the life cycle.

According to the traditional categorization by Esping-Andersen [20], the Nordic welfare state model is based on a social democratic ideology and built around the central role of state in providing security and welfare such as social, educational and health services. Social 
benefits are available to all members of society and the main mechanism supporting social security and ensuring equality is progressive income transfer. Particular examples of equal welfare services are uniform child and childcare benefits for all and free primary to tertiary education.

\subsection{Methods}

The research approach used in this study is explorative (see [83], 5-9); instead of constructing an empirical study with robust evidence, we aim to contribute to the literature by constructing a fresh viewpoint and discussing its implications. By presenting and analysing the case of Finland adapting to climate change and reducing disaster risk, we aim to bring about interesting observations of DRR and CCA processes and frameworks in general. Two research questions guided our work: 1) How well do the existing DRR and CCA approaches reflect the perspectives of the least vulnerable and exposed countries? 2) Do the current ways of determining vulnerability and exposure undermine some climate or disaster risks or hinder the seizing of opportunities brought about by climate change?

The case study is built on data gathered in two research projects, one Nordic and one Finnish. The collaborative Nordic research project undertaken within NORDRESS Centre of Excellence on Resilience and Societal Security ${ }^{3}$ analysed the institutional foundations of natural hazard management within Nordic countries (for more detailed description, see [32]). This study gathered views of experts working with DRR and CCA through an online survey (47 responses), semi-structured interviews ( 8 interviewees) and a two-day expert workshop (15 participants). In addition, a broad desk study was conducted in which grey literature, legislation and official guiding documents defining DRR and CCA processes within the Nordic countries were reviewed. The final outcome of the study was a comparative analysis of the similarities and differences within these processes and related institutions in Denmark, Finland, Iceland, Norway and Sweden. The data was collected in 2015 and 2016.

The Finnish project analysed various aspects of weather and climate risks in Finland under the Government's analysis, assessment and research activities (see [30]). The ELASTINEN ${ }^{4}$ project was structured around multiple parallel analyses, and data were collected using various methods. For this paper, the most relevant data was collected in an online survey, seven interviews and a workshop. The online survey covered perceived weather and climate risks, use of weather and climate information and improving preparedness. The survey was aimed at Finnish organizations in general and received 118 responses. Analysis of the responses for a similar survey targeted at municipalities is reported in Räsänen et al. [67]. The workshop was held in January 2016, had 42 representatives of different private and public stakeholder organizations and consisted of interactive sessions that aimed to validate and complement the results of the online surveys and collect views on how to improve climate risk management tools and information services in Finland. The interviews were held with experts working on flood risk management and CCA in Helsinki, the capital of Finland.

In addition to the observations and conclusions made in these projects, the case description and analysis was complemented by available literature and statistical data. All three authors have also been involved in various DRR and CCA research projects, consultations and interaction events in Finland, and use their personal experiences in forming a consistent case description out of fragmented and diffuse data available. In our case study writing, we include references when presenting exact claims or relevant conclusions from earlier literature; otherwise the claims are based on our interpretation of the data and observations

\footnotetext{
${ }^{3}$ NORDRESS (Nordic Centre of Excellence On Resilience and Societal Security) http:// nordress.hi.is/ [Accessed 8.12.2017].

${ }^{4}$ ELASTINEN (Proactive management of weather and climate related risks) http://en. ilmatieteenlaitos.fi//elastinen [Accessed 8.12.2017].
}

collected within the two projects.

While some of the conclusions are based on quantitative data, our study is mostly based on qualitative research. It follows loosely the so called "Gioia Method" $[29,49]$ in choosing a single case for its revelatory potential and aiming for conceptual contribution instead of theory development. As a case study, it is exploratory and intrinsic in nature but with some descriptive elements (see [5]). The intent is not to achieve generalizations beyond the limited frame of Nordic welfare states or to evaluate specific policies nor to validate premeditated hypotheses. Instead, we aim at constructing a revealing and interesting case that provokes new ideas and discussion on how DRR and CCA can and should be approached.

\section{Finland - a country without weather and climate risk?}

\subsection{Disaster risk}

Finland is located in North-Eastern Europe. Together with Denmark, Sweden, Iceland and Norway, it is one of the Nordic countries. The climate is challenging for primary production and logistics, and without modern technology and good governance, food production would most likely be disaster-prone. The worst famine in Finland's history occurred approximately 150 years ago, and resulted in the death of estimated $8 \%$ of the population and was the result of long-term societal, economic and political factors, which were exacerbated by rainy summers and frost in September 1867 [92]. However, considering the vulnerability, hazard and exposure aspects, one could summarize that nowadays, because of the welfare state characteristics with high social cohesion, trust, equality, relative wealth, and mild natural hazard levels compared to other countries, Finland is a country with low weather and climate risk.

The damages from natural hazards that have occurred in recent years demonstrate the country's relatively low weather and climate risk level. As an example, cyclone Gudrun which hit Denmark, Sweden and Estonia in January 2005 resulted in 75 million $\mathrm{m}^{3}$ of fallen forest in southern Sweden, ${ }^{5}$ whereas the largest recorded forest damage in Finland has been approximately 8.1 million $\mathrm{m}^{3}$ in 2010 , caused by four consecutive extra-tropical cyclones in the summer 2010. Between 2011 and 2015 in Copenhagen, Denmark, major urban downpours have caused total economic damage worth approximately 1.2 billion euros [12], whereas the flood caused by heavy rains in the city of Pori in 2007 damaged buildings and infrastructure, and resulted in estimated costs of 22 million $€[11]$.

\subsection{Climate}

In global comparison, natural hazards are rather modest, and none of the geophysical characteristics can be described as extreme. The earthquakes are rarely above 2 in magnitude [35]. Finland lies far from volcanic hot spots and the edges of the Eurasian tectonic plate: there are no volcanoes and the miniscule earthquakes can only be detected using sophisticated technical equipment. Slopes are low and gradual and thus limit gravitational flows, although avalanches are not completely unheard of in the low mountains in Lapland [74]. The climate is a mix of continental and maritime climate and in general more continental compared to the rest of the Nordic countries [25,26]. It can be characterised by high variability in seasonal climatological cycles and high climate variability [64]. More specifically, five climate zones are identified following the Köppen climate classification (the impact of temperature and precipitation on vegetation): hemi-boreal, southboreal, middle boreal, north-boreal and subarctic [26]. Storms are most frequent in late autumn and winter when they are driven by major

\footnotetext{
${ }^{5}$ http://www.smhi.se/kunskapsbanken/meteorologi/gudrun-januaristormen-2005-1.
} 5300 [Accessed 8.12.2017]. 
depressions, but they can take place throughout the year [40]. Storm winds also occur during convective thunderstorms mostly in summer months. The absolute wind speeds in these storms are again modest in international comparison. There are, for instance, no known instances of hurricane level wind speeds over $33 \mathrm{~m} / \mathrm{s}$ at least as long as modern observations have been made [28].

The discharge of the free running rivers is small in comparison to for instance the big rivers in central Europe and while they can cause fluvial flooding, the severity of these events is low on an international scale. Yet floods do happen, and the seasonal discharge patterns are projected to change in the future, which will also affect flooding [90].

Finland has already witnessed warming in its climate during the last 150 years [51], and the future warming is expected to be significantly higher than the global average [51,70]. In general, the climate will get wetter and hotter. Winter months warm the most, and winters become moister, cloudier and less snowy [69]. Sea level rise on the coast is partially compensated by the residual land mass uplifting still following the loss of ice cover from the last ice age. Yet, the projections show that sea level will rise by the end of the century by $29 \mathrm{~cm}$ in the Gulf of Finland, while in the Bothnian Sea and Bothnian Bay the change is $5 \mathrm{~cm}$ and $-27 \mathrm{~cm}$, respectively, due to the landmass uplift [38].

\subsection{Governance of weather and climate risks}

Finland has been an active participant in the international cooperation within the United Nations International Strategy for Disaster Reduction (UNISDR). Finland had a high profile in the development of the Hyogo Framework for Action [88]. Domestically, Sendai [87] and Hyogo frameworks have resulted in co-operation networks between authorities and Finland has prepared extensive reports on its DRR actions [32]. In 2016, the 7th annual meeting of the European Forum for Disaster Risk Reduction in was organised in Helsinki as Finland was the European regional chair. Three important outcomes, which were also mentioned by Finland at the Global Platform on Disaster Risk Reduction held in Cancun 24-26 May 25, 2017 were:

"First, we need a stronger engagement by political leaders and decision makers in moving forward the DRR agenda and Sendai Framework implementation. Second, we need strengthened coherence and mutually reinforcing implementation between the Sendai Framework and other recent international agreements and processes, including the 2030 Agenda for Sustainable Development, the Paris Agreement on climate change and the New Urban Agenda - not only in theory but also in practice. Third, we need reliable reporting mechanism based on agreed terminology and indicators".

Yet, the national governance structures are more complex than implied by the statements in international fora. DRR and CCA governance follows the internationally witnessed separation of the DRR and CCA fields, as shown in Fig. 1. The Ministry of the Interior, responsible for civil security and safety, has a coordinating, rather than commanding, role in emergency situations and it acts as the national focal point for DRR. The Ministry of Agriculture and Forestry is responsible for CCA coordination.

The main DRR governance principles are self-sufficiency, which refers to the idea that the responsibilities and roles of authorities, organizations and individuals are the same in both normal and exceptional conditions (i.e. there is no national civil protection agency that would take control in disaster situations); and locality, which complements the idea of self-sufficiency (i.e., disasters are managed on the lowest possible level and only if escalated). The National Risk Assessment 2015 [55] assesses six events that have a major impact on society and 15 events that have serious regional impacts. Nine of these events are directly or indirectly related to weather and climate:
- solar storms,

- rapid flooding in or near the population centre,

- large marine accidents due to e.g. harsh winter navigation conditions,

- multiple simultaneous extensive forest fires,

- extensive or long-lasting disturbance of water distribution due to e.g. storm,

- winter storms including long frosty periods,

- thunderstorms.

From a holistic risk reduction perspective, threatening weather and climate risks are included in the Security Strategy for Society [75], given as a Government Resolution and coordinated by the Security Committee. The Security Strategy describes the roles of different national entities in the face of disasters, and is based on a holistic crosssectorial viewpoint, emphasizing vertical and horizontal responsibilities. Together these principles mean that DRR is quite polycentric and the responsibilities are distributed to various authorities on different jurisdictional levels. All ministries, and the Prime Minister's Office, the National Emergency Supply Agency, ${ }^{6}$ six Regional State Administrative Agencies, 22 rescue departments, the 317 municipalities, as well as several national agencies and institutes, and the civil society have important regional or national roles in DRR during normal and exceptional circumstances.

This arrangement was described as a "mess" in one of our workshops. However, the complex and decentralized organization of DRR has been compensated by co-operative and coordinating measures. As a result, there is little overlap in responsibilities or capacities of different authorities, although the chains of command and operative procedures can turn out to be complex during an exceptional event. Finnish authorities also a have long tradition of co-operation between different sectors as well as the private sector, that stems from cold-war era civil defence preparedness. This idea of total defence, based on the concept of comprehensive security, is unique in international comparisons [34] and has provided continuity in national preparedness policies despite of the collapse of the Soviet Union $[48,65]$.

The 'messiness' is not reflected in the survey on the management of global risks conducted by the World Economic Forum for their 2013 Risk Report ([93, p. 66]), where 36 'top managers' from Finland were asked to assess their "national government's overall risk management effectiveness of monitoring, preparing for, responding to and mitigating against major global risks". In the survey, Finland ranked 9th out of 139 countries surveyed, indicating that the government is considered to be well capable of managing the risks faced by Finland.

The Ministry of Agriculture and Forestry has ensured that, if measured by national level strategy work, Finland can be considered a CCA pioneer [40]; as witnessed by the first national adaptation strategy in Europe in 2005 [54]. Finland and Denmark are forerunners in Nordic CCA, in that they both have explicit requirements for CCA in their land use planning legislation, whereas the other three Nordic countries do not [32].

The revised National plan for Climate Change Adaptation 2022 was set in 2014 as a governmental order [53], and sets three overarching goals: a) mainstreaming adaptation, b) providing necessary climate risk assessment and management tools, and c) improving adaptive capacity, creating innovative solutions and increasing public awareness with research and development, communication and education. These goals are pursued by 14 actions, each of which consists of a set of more detailed actions with assigned responsibilities and resources [53]. Although opportunities are brought up, alongside risks and indirect impacts, the general tone of the strategy is quite conventional. It describes a general process of climate risk management where changes and risks are identified, the risks are assessed according to their likelihood and
- serious disturbances in electricity distribution due to e.g. storms,

- information security risks due to e.g. storms or floods, 


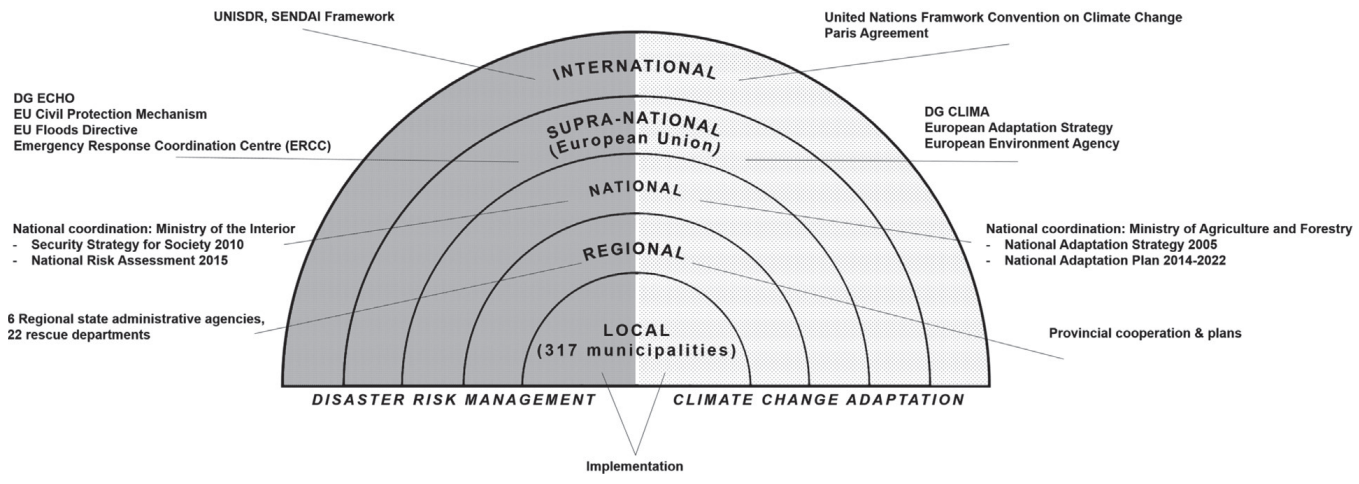

Fig. 1. CCA and DRR governance levels and examples of governing bodies and guiding frameworks in Finland.

impact, and solutions are developed accordingly.

Two challenges regarding effective CCA implementation have been identified. Finland, among other Nordic countries, has been a forerunner in CCA research [46]. However, Klein and Juhola [46] point out that there has been a gap between research and putting policies into practice. This gap results from the distance between the theoretical concepts and the reality of decision-making, uncertainty of information, scale mismatch between climate information and actions, prioritization of current variability and short-term decisions; in contrast to the medium- to long-term perspective of adaptation research, and forgetting the fact that CCA is only one of many stakeholder concerns and seldom the most salient [46]. This challenge was confirmed by the observations from our projects as well.

Another challenge stems from bridging national and regional and local adaptation actions [42]. National high-level strategies have had limited impact on the regional and municipal levels where the lack of skills and resources hinder the implementation of actions. Juhola et al. [42] describe how regional climate work is almost completely projectbased and relies on external funding. The same point was made in a workshop held in the ELASTINEN project. Stakeholders from both public and private organizations expressed their frustration on endless stream of projects and hoped to see continuous work toward holistic CCA. Thus, without resourcing or new arrangements of responsibilities, the goal of CCA mainstreaming is difficult to achieve.

The integration of DRR and CCA is currently taking place at research level, as the national weather and climate risk assessment commissioned by the Prime Minister's Office considers extreme weather events and longer-term changes in the Finnish climate. Integrating DRR and CCA into other global policy contexts, such as the Sustainable Development Goals, however, remains to be seen.

\subsection{The Nordic welfare model and vulnerability reduction}

From vulnerability perspective, Finland is well prepared to face the impacts of extreme weather events and climate change. The GDP per capita was approximately 39,000 euros in 2016 [80], ranking 8th within the European Union [22] and Finland is, for instance, the 8th best performing country according to the Better Life Index of the Organization for Economic Co-operation and Development. ${ }^{7}$ The economy relies mostly on services: $70.2 \%$ of value added as proportion of gross value added comes from services, $27.1 \%$ from secondary production and $2.7 \%$ from primary production (preliminary statistics for 2016) [80]. Due to its broad social security and public services, Finland can be

\footnotetext{
${ }^{7}$ http://www.oecdbetterlifeindex.org/\#/11111111111 [Accessed 8.12.2017].
}

considered a welfare state, and more specifically a Nordic or Scandinavian welfare state [66].

The Nordic welfare state expresses itself in various ways within the economy and society. Equality in income distribution, high institutional trust and high level of education are all general characteristics of Nordic welfare states. The income distribution is in global comparison quite flat; the most recent Gini coefficient was 0.257 , 5th lowest in the OECD countries. ${ }^{8}$ Finns have in general high levels of trust for each other, the political and legal systems and the authorities; levels of trust to all of these are high in international comparison, and in some of them Finland ranks on top [47]. Finland is a top scorer in the yearly Corruption Perceptions Index by Transparency International; in 2015 it was the third least corrupt country in the world after Denmark and New Zealand. ${ }^{9}$ Finns are also quite highly educated, with $71 \%$ of population over 15 years of age holding a degree beyond primary schooling [81]. The population is fairly homogeneous as only $4 \%$ of inhabitants are foreigners and $90 \%$ of the population speak Finnish as their native language and almost $86 \%$ of the population live in cities or towns [82] Urbanization is progressing further quite rapidly. According to the Gender Inequality Index measured as part of the Human Development Index of the United Nations Development Programme, in 2015 Finland ranked 8th most gender equal country in the world [85]

The public has a high trust in the ability of the society to recover from disasters, and Finns are willing to help each other and provide volunteer aid in disasters. Households consider themselves well prepared for disasters or contingencies in general, but there is a significant difference in preparedness between rural and urban populations; the former are better prepared [50].

\subsection{Examples of implementation}

Not only is the entire welfare state structure and the dispersed governance system based on the idea of 'comprehensive security', but specific, integrated DRR and CCA measures have been designed and implemented since 2000 .

A good example of a highly effective, although not necessarily economically efficient, DRR and CCA integration is the amended Electricity Market Act 2013 [71]. The Act was partly a response to the long, regional power outages caused by winter and summer storms, and is a good example of a national level response to regional challenges. The Act poses strict requirements on the length of electricity blackouts;

\footnotetext{
8 http://www.oecd.org/social/income-distribution-database.htm 8.12.2017].

${ }^{9}$ http://www.transparency.org/cpi [Accessed 8.12.2017].
}

[Accessed 
in rural areas (excluding premises without permanent residents), blackouts shall not last over $36 \mathrm{~h}$, and in urban areas, blackouts shall not last over $6 \mathrm{~h}$. If these thresholds are not met, the electricity distribution companies have to pay heavy compensation to their customers. The transition period lasts until 2029, and mid-term goals have to be reached by 2019 and 2023. This has led to a situation where many electricity distribution companies are required to improve the reliability of their networks, mainly through converting traditional air-cable lines into underground cables. However, a cost-benefit analysis of the enactment of the Act shows that the electricity companies enforced the law by the installation of ground cables and the economic feasibility of the law enactment varies according to the discount rate. With a $3 \%$ discount rate the benefits are greater than the costs, whereas with $5 \%$ discount rate the benefits are smaller than the costs. This highlights the fact that in the Finnish context, where disaster risk is in many ways under control, large investments in DRR and CCA are not necessarily economically efficient. [61]

An example of a well-functioning multi-sectoral, integrated DRR and CCA activity is the early warning service LUOVA [27]. Launched in 2012 , it is used to distribute natural hazard and early warning information to the highest government officials and all security authorities. In addition, more limited announcements are available for a broader range of subscribers. LUOVA is maintained by the Finnish Meteorological Institute while warnings are also prepared by the Finnish Environment Institute and the Seismologic Institute within the University of Helsinki. The hazards are monitored both in Finland and abroad to be able to safeguard Finns and the interests of Finland globally. LUOVA is an operational early warning system to enable efficient preparedness and response in the face of an emergency situation. Therefore, it does not directly include climate change information or scenarios. However, early warning systems are an efficient way of reducing also the impacts of climate change in the face of projected changes in extreme weather events and, for instance, related to changing winter driving conditions [62]. Another similar DRR and CCA measure is the Flood Centre, jointly operated by the Finnish Meteorological Institute and the Finnish Environment Institute. The purpose of the Flood Centre is to forecast and warn of impending flooding situations to authorities, and residents and businesses in flood-prone areas.

The prioritization of CCA actions seems, however, to be one of the key challenges both in private and public Finnish organizations. Spatial planning is perhaps the activity where CCA mainstreaming has been developed the furthest; as there are clear regulations or at least nonbinding guidance on managing flood risk, including storm water and sea level rise [91]. In largest cities, resources are not an issue as there is expertise to properly design adaptation. Still, other priorities such as housing targets or other economic drivers result in changes that hinder the planned adaptation when spatial plans are implemented or when areas are maintained.

\subsection{Risk perception}

The relatively low risk-level is also reflected in the risk perceptions. While flooding and storms are considered potentially harmful by households [50], the likelihood of problems created by extreme weather and climate events is considered low [44]. In the ELASTINENstudy, organizations considered weather and climate risks on average as relatively small-but not insignificant-compared to all risks in general [31]. Furthermore, the study found that heavy rains, flooding and storms were the main hydro-meteorological concerns of the respondent organizations that included both public and private sector entities across the country. When looking to the future, organizations considered extreme events as a more significant threat than gradual changes in climate. The idea that climate change is not a direct threat to society seems to be reflected in risk perceptions too. Finns are among the least worried Europeans when it comes to climate change [21] and in the organizational survey, a majority of the ELASTINEN-study respondents considered climate change to create positive impacts or benefits, such as new business opportunities or improvement in relative competitiveness [31].

Despite of, or perhaps due to, the challenging climate that the businesses operate in, low priority of CCA shows as low awareness. While awareness of climate change mitigation and the importance of corporate social responsibility may be on the rise, CCA actions, beyond fulfilling scattered regulations, have been rare among Finnish enterprises. Furthermore, low demand for CCA related climate information or services has been witnessed. From business perspective, CCA does not stand out as a distinct activity but has instead merged within other risk management processes. According to the results of the ELASTINEN survey [31], the lines between climate change adaptation and mitigation are also blurred in Finnish businesses, as globally suggested by Okereke et al. [58].

The general consensus is that the expected climatic changes may actually result in direct benefits to the economy. In agriculture, the growing season becomes longer [60], the increased warmth and $\mathrm{CO}_{2}$ accelerates forest growth [45] and the need for space heating decreases [43] It is not surprising that the wish for a more pleasant European climate is a recurring joke in Finnish events or meetings focusing on climate change. Yet things are not that straightforward. Less ice and snow on the road can mean less accidents, but if these conditions come even more as a surprise the risk of accidents may increase [72]. Moreover, the costs of maintaining the road infrastructure will probably increase due to climate change [24]. Naturally, there are also concerns of directly adverse impacts of climate change.

\section{Discussion}

\subsection{The Finnish model - success story with looming unrecognised risks?}

What can we then learn from the Finnish perspective on CCA and DRR? The established IPCC framework that defines natural hazards, vulnerability and exposure as the determinants of climate or disaster risk does not reflect the Finnish situation very well. Objectively assessed, all these factors and thus risks are low, and in international comparison they are even lower. The physical reality is reflected in organizational and individual perceptions; Finns do not feel threatened by weather or changing climate.

Still, as described, Finnish climate can be challenging, and Finns are for example able to manage snow and temperature conditions (e.g temperatures down to $-45^{\circ}$ to $-50^{\circ}$ centigrade in northern Finland) that could be nearly disastrous in other societies. This DRR and CCA has not, however, resulted from modern DRR and CCA policies but is more a result of learning from experience, good governance and improved adaptive capacity due to rising living standards and better technology, which has been put to use with resolve. Yet, it is difficult to evaluate whether Finland is well prepared and able to adapt to future challenges. This is especially true for climate change which has the potential to cause indirect risks, countering the potential local benefits of climate change. As pointed out in O'Brien et al. [57]; Johannessen and Hahn [38]; and Klein and Juhola [46], when climate risks are perceived to be low, the resulting complacency might lead to inaction in adaptation despite the theoretically high adaptive capacity. Based on our observations, this may be a very conceivable risk for Finland.

While it may be that the direct climate change impacts are not severe compared to other countries, there are indirect mechanisms that can cause harm and damage (see an overview for Europe in [16]). Finland is economically, politically, socially and biophysically connected to the rest of the world, and changes abroad will have ripple effects here as well [33]. Naturally, the indirect impacts within a global economy are likely to be mostly negative and can in some cases be more severe than the direct ones [33]. Also, seizing the potential opportunities requires active CCA. Broader environmental sustainability issues, such as increased eutrophication due to increased agriculture, may also 
become an issue. Furthermore, the joint occurrence of natural hazards and purely man-made risks (such as cybercrime etc.) may be an event which is hard to assess from probabilistic perspective, but may well pose a serious threat to the functioning of society.

The Finnish case enhances the notion that natural hazard, exposure and vulnerability are highly context-dependant. In a welfare state with low levels of absolute risks, a very straightforward interpretation of the key DRR and CCA concepts can lead to policy work that does not guide or connect to actions in practice. DRR and CCA frameworks can be thought of as a spectrum, where very different situations between countries should be reflected in risk assessments. There are countries where the most threatening hazards are self-evident, exposure has clear geographic and physical definitions and where economic welfare can be used directly as a proxy for vulnerability. Finland as a Nordic welfare state with low levels of natural hazards and exposure is not such a country.

How do DRR and CCA then come together in Finland as a whole? A fitting phrase to describe Finnish approach is "by the book". Strategies and policies are in place and they are developed according to up-to-date views within the fields, emphasizing co-operation and integration of DRR and CCA with each other and into other policy fields, broad definitions of risk and focusing on prevention over damage control. In parallel to this high-level strategy work, everyday operations linked to DRR and CCA such as spatial planning, construction work and emergency services are run and developed according to their short-term learning cycles. Based on our observations, these two levels are-while not completely separated-not always very closely interacting. It is possible that society is highly adapted to current climatic variations and disaster possibilities, but qualitative changes and new types of risks might catch Finns by surprise, even if these risks could in principle be anticipated.

This gap makes evaluating the effectiveness of Finnish DRR and CCA difficult. Another complicating factor is the fact that there are no frequent disasters or significant adverse climate change impacts. In this sense, the Finnish DRR and CCA have not yet been put in a test, so it cannot be stated whether they are in line with the risks or not. What is lacking from the strategies though, is clear prioritization. The scale of impact of different risks is however likely to vary significantly.

Does the case of Finland provide any lessons learnt for countries where hazard and governance profiles are substantially different? The transferability of the Nordic social welfare model is beyond the scope of this paper, as the process of transferring institutional structures between states is complex and contingent in itself (see e.g. [69]); and there has also been debate about the viability of the Nordic welfare model in an increasingly globalised economies [3]. However, the governance structures, social cohesion, well-functioning institutions and relatively equal society are a direct reflection on the factors of the 'elephant in the room' by Alexander and Davis [2] and the UNISDR [85]. In this paper, we show that by addressing these issues at governance level provide major benefits in reducing weather and climate related disasters prior to their occurrence.

\subsection{Broadening the key concepts}

Following the example of Finland, the key weather and climate risk concepts; hazard, exposure and vulnerability, could be adjusted as follows:

For vulnerability, relative changes in perceived social trends and social cohesion should be emphasized. As we've seen we've the rise of extremist and populist movements in Europe and the United States, even a developed, growing and stable economy can start imploding if large parts of society feel threatened or disempowered by future societal development. It does not necessarily matter whether or not the perceived risks are real in any meaningful scale, as long as they are perceived to matter. Such implosion may then threaten governance structures and legitimacy and indirectly but significantly affect DRR and CCA capacities.

Socio-economic vulnerability reduction should be key in reducing people's and societies' capacity to reduce and cope with extreme weather events and climate change. The social welfare system, present in the Nordic countries, can be considered as holistic vulnerability reduction in the sense that it provides people with the economic means to cope with many of the risks that are present in modern life, not only weather and climate related risks. This increases people's capacity to function in exceptional situations and disturbances, regardless of their origin. People have the economic means to live in resilient buildings, and even in the case of loss of livelihood, the state takes care of one's, and one's family's, basic needs. This can be complemented with a holistic approach to infrastructure resilience, which according to Pursiainen [65] is the approach in the Nordic countries which focus "on vital societal functions rather than mere sector-based infrastructures" in their approach to securing critical infrastructure from multiple threats.

Exposure and hazard should not be limited to direct geographical or physical exposure to local natural hazards. Finns and Finnish organizations can be exposed to natural hazards, disasters and climatic changes across the globe; therefore, a network view on exposure is necessary.

Finally, the flip-side of risk should not be forgotten: Opportunity identification might seem macabre when discussing disasters or climate change, but the benefits harvested in seizing opportunities can be used to improve disaster risk management at home and abroad.

Here it should be noted that this study is exploratory and issueraising in nature. Our analysis is not detailed enough to give direct advice on policy development. Instead we are promoting a more flexible and effective approach to designing integrated DRR and CCA policies. This calls for more research, both academic and practice-oriented, as well. A more nuanced scientific global risk assessment, mapping and modelling of complex causal effects regarding disaster and climate change impacts would clarify the global risk landscape and improve assessments of the global costs of adaptation and postponed mitigation. On a national scale, applied research on the scale and determinants of different risks should be conducted with a broad perspective. Naturally, we are not the only or first ones to suggest this, but we consider that our example of Finland shows that work remains to be done.

\section{Conclusions}

DRR and CCA are global efforts that call for international co-operation and increased integration at all levels of governance. Global and international perspectives should not, however, blur the view of the differences between countries and regions. Finland as a Nordic welfare state with low natural hazard levels serves as an example of a certain type of extremity with regard to DRR and CCA. We argue that the most severe weather and climate risks for modern-day Finland may be indirect. Thus, the most cost-effective investments to improve preparedness are likely to be ones that affect the root causes of these indirect risks. On the opposite end of the spectrum, for a poor and natural hazard prone country, direct investments in DRR and CCA capabilities may be more efficient. However, good governance and functioning institutions are a prerequisite to any such improvements and in principle clear-if perhaps in practice very difficult-steps to improve the situation: e.g. poverty reduction, improving administration, developing agricultural practices and increasing awareness, exist. For a Nordic welfare state with powerful institutions, high institutional and societal trust, low levels of disasters despite challenging climate, and a high level of capital and living standards, the path forward is less clear. Regardless of whether the Nordic welfare state model or parts of it are transferable, the analysis shows that the role of governance, as stated by Alexander and Davis [2] and UNISDR [85] is crucial in reducing weather and climate related disaster risk.

The complex nature of disaster risks and climate change calls for 
more research. Further analysis is required on the contribution of different welfare state regimes to successful DRR and CCA, and how the changing cultures and governance regimes that are witnessed in the Nordic countries at the moment contribute to changing weather and climate risk. The role of political systems and culture as enabling factors for successful DRR and CCA should also be further studied. Further analysing the relation of contingent needs and conditions in comparison to the general frameworks could yield tools for measuring DRR and CCA resource efficiency. Altogether a more nuanced research approach would support more effective DRR and CCA policies and improve our conceptual and factual understanding of global risks. In addition to increasing DRR and CCA integration, integrating both into other global policy processes, such as Sustainable Development Goals, would be beneficial in the long run. Research into these topics can support this effort.

\section{References}

[1] D. Alexander, Mainstreaming disaster risk management, in: L. Bosher (Ed.), Hazards and the Built Environment: Attaining Built-in Resilience, Taylor \& Francis, Oxford, UK, 2008, pp. 20-36.

[2] D. Alexander, I. Davis, Disaster risk reduction: an alternative viewpoint, Int. J. Disaster Risk Reduct. 2 (2012) 1-5, http://dx.doi.org/10.1016/j.ijdrr.2012.10.002.

[3] T.M. Andersen, B. Holmström, S. Honkapohja, S. Korkman, H.T. Söderström, J. Vartiainen, The Nordic Model: Embracing Globalization and Sharing Risks. ETLA B232, The Research Institute of the Finnish Economy (ETLA), Helsinki, 2007 〈http://economics.mit.edu/files/5726〉 (Accessed 8 December 2017).

[4] M.B. Anderson, Which costs more: prevention or recovery? in: A. Kreimer, M. Munasinghe (Eds.), Managing Natural Disasters and the Environment, World Bank (Environment Department), Washington DC, 1991, pp. 17-27.

[5] P. Baxter, S. Jack, Qualitative case study methodology: study design and implementation for novice researchers, Qual. Rep. 13 (2008) 544-559.

[6] G.R. Biesroek, R.J. Swart, T.R. Carter, C. Cowan, T. Henrichs, H. Mela, M.D. Morecroft, D. Rey, Europe adapts to climate change: comparing national adaptation strategies, Glob. Environ. Change 20 (2010) 440-450, http://dx.doi. org/10.1016/j.gloenvcha.2010.03.005

[7] J. Birkmann, K. von Teichman, Integrating disaster risk reduction and climate change adaptation: key challenges - scales, knowledge, and norms, Sustain. Sci. 5 (2010) 171-184, http://dx.doi.org/10.1007/s11625-010-0108-y.

[8] N. Brooks, W.N. Adger, P.M. Kelly, The determinants of vulnerability and adaptive capacity at the national level and the implications for adaptation, Glob. Environ. Change 15 (2005) 151-163, http://dx.doi.org/10.1016/j.gloenvcha.2004.12.006.

[9] I. Burton, Climate change and the adaptation deficit, in: E.L.F. Schipper, I. Burton (Eds.), The Earthscan Reader on Adaptation to Climate Change, Earthscan, London, 2009.

[10] Centre for Research on the Epidemiology of Disasters - CRED, n.d. EM-DAT The International Disaster Database. URL 〈http://www.emdat.be/database〉 (Accessed 8 December 2017).

[11] City of Pori. Porin kaupunkitulva 12.8.2007 Loppuraportti (Pori Urban Flood 12.8. 2007). (In Finnish). URL 〈http://pori.fi/material/attachments/hallintokunnat/ tekninenpalvelukeskus/ajankohtaistaliikenteesta/raportit/5vA4Hx8Kn/ Kaupunkitulvaraportti-lopullinen-22102009.pdf> (Accessed 12 August 2017).

[12] Climate-ADAPT, European Climate Adaptation Platform. The economics of managing heavy rains and stormwater in Copenhagen - The Cloudburst Management Plan, 2016. URL 〈http://climate-adapt.eea.europa.eu/metadata/case-studies/theeconomics-of-managing-heavy-rains-and-stormwater-in-copenhagen-2013-thecloudburst-management-plan>.

[13] COM (European Commission), Communication from the Commission to the European Parliament, the Council, the European economic and social committee and the committee of the regions - an EU strategy on adaptation to climate change, COM (2013) (2013) (216 final).

[14] Decision No 1313/2013/EU of the European Parliament and of the Council. The Union Civil Protection Mechanism (UCPM). URL 〈http://eur-lex.europa.eu/legalcontent/EN/TXT/PDF/?Uri = CELEX:32013D1313\&from $=$ EN $>$ (Accessed 8 December 2017).

[15] Directive 2007/60/EC of the European Parliament and of the Council. On the Assessment and Management of Flood Risks. URL 〈http://eur-lex.europa.eu/legalcontent/EN/TXT/PDF/?Uri $=$ CELEX:32007L0060\&from $=$ EN $>$.

[16] EEA (European Environment Agency), Climate Change, Impacts and Vulnerability in Europe 2016 - An Indicator-based Report. EEA Report 1/2017, Publications Office of the European Union, Luxembourg, 2017〈https://www.eea.europa.eu/ publications/climate-change-impacts-and-vulnerability-2016/at_download/file〉.

[17] K. Eisenack, S.C. Moser, E. Hoffmann, R.J.T. Klein, C. Oberlack, A. Pechan, M. Rotter, C.J.A.M. Termeer, Explaining and overcoming barriers to climate change adaptation, Nat. Clim. Change 4 (2014) 867-872, http://dx.doi.org/10.1038/ nclimate2350.

[18] S.H. Eriksen, K. O'Brien, Vulnerability, poverty and the need for sustainable adaptation measures, Clim. Policy 7 (2007) 337-352, http://dx.doi.org/10.1080/ 14693062.2007.9685660

[19] E. Esping-Andersen, Why We Need a New Welfare State, Oxford University Press,
New York, 2002, http://dx.doi.org/10.1093/0199256438.001.0001.

[20] E. Esping-Andersen, The Three Worlds of Welfare Capitalism, Princeton University Press, Princeton, New Jersey, 1990.

[21] European Commission, Special Eurobarometer 409 - Climate Change, European Commission, Directorate-General for Climate Action (DG CLIMA), 2014, 〈http://ec europa.eu/public_opinion/archives/ebs/ebs_409_en.pdf> (Accessed 23 February 2017).

[22] Eurostat, Gross Domestic Product at Market Prices, (2017) 〈http://ec.europa.eu/ eurostat/web/products-datasets/-/tec00001\&lang = en > (Accessed 8 December 2017).

[23] S. Fankhauser, T.K.J. McDermott, Understanding the adaptation deficit: why are poor countries more vulnerable to climate events than rich countries? Glob. Environ. Change 27 (2014) 9-18, http://dx.doi.org/10.1016/j.gloenvcha.2014.04. 014.

[24] Finnish Road Administration, Central Administration. The Effect of Climate Change on the Routine and Periodic Maintenance of Roads (In Finnish with English Abstract). Finnra report 8/2009. Helsinki. URL 〈http://alk.tiehallinto.fi/julkaisut/ pdf2/3201122-v-ilmastonmuutoksen_vaikutus_kunnossapitoon.pdf $\rangle$.

[25] FMI (Finnish Meteorological Institute). Climate in Finland. Official FMI web site, 2017. 〈http://en.ilmatieteenlaitos.fi/climate〉 (Accessed 8 December 2017).

[26] FMI (Finnish Meteorological Institute). Suomen ilmastovyöhykkeet (In Finnish). Official FMI web site, 2017. 〈http://ilmatieteenlaitos.fi/suomenilmastovyohykkeet> (Accessed 23 November 2017).

[27] FMI (Finnish Meteorological Institute), LUOVA answers the authorities' need for information when a natural disaster occurs, FMI News (2016), 〈http://en. ilmatieteenlaitos.fi/news/286502165> (Accessed 8 December 2017).

[28] FMI (Finnish Meteorological Institute), Record winds in Finland (in Finnish), 2015. 〈http://ilmatieteenlaitos.fi/tuuliennatyksia〉 (Accessed 8 December 2017).

[29] D.A. Gioia, A renaissance self: prompting personal and professional revitalization, in: R.E. Stablein, P.J. Frost (Eds.), Renewing Research Practice, Stanford University Press, Stanford, CA, 2004, pp. 97-114.

[30] H. Gregow, T. Carter, F. Groundstroem, R. Haavisto, S. Haanpää, M. Halonen, A. Harjanne, M. Hildén, J. Jakkila, S. Juhola, A. Jurgilevich, A. Kokko, V. Kollanus, T. Lanki, S. Luhtala, I. Miettinen, A. Mäkelä, V. Nurmi, K. Oljemark, A. Parjanne, P. Peltonen-Sainio, A. Perrels, K. Pilli-Sihvola, A.-J. Punkka, T. Raivio, A. Räsänen, K. Säntti, H. Tuomenvirta, N. Veijalainen, O. Zacheus, Measures to promote the management of weather and climate related risks (in Finnish with English abstractKeinot edistää sää- ja ilmastoriskien hallintaa), ubl. Gov. Anal. Assess. Res. (2016) Act. No. 47/2016 http://tietokayttoon.fi/julkaisu?pubid =15406.

[31] A. Harjanne, R. Haavisto, H. Tuomenvirta, S. Luhtala, A. Mäkelä, H. Gregow, M. Halonen, T. Raivio, M. Hildén, A. Parjanne, J. Jakkila, S. Juhola, A. Räsänen, S. Haanpää, A. Jurgilevich, P. Peltonen-Sainio, T. Lanki, I. Miettinen, O. Zacheus, V. Kollanus, Management of Weather and Climate Risks and the use of Related Information Sources in Finland (In Finnish with English Abstract). FMI Reports 2016:6, Finnish Meteorological Institute, Helsinki, 2016 〈https://helda.helsinki.fi/ handle/10138/168693 > (Accessed 4 December 2017).

[32] A. Harjanne, E. Pagneux, L.F. Jørgensen, A. Perrels, P. van der Keur, F. Nadim, J.K. Rød, E. Raats, Resilience to Natural Hazards: An Overview of Institutional Arrangements and Practices in the Nordic Countries. NORDRESS WP6.1 Report, (2016) 〈http://nordress.hi.is/wp-content/uploads/2015/01/WP6-1-report-oftask1-country-review_formatted.pdf $>$ (Accessed 8 December 2017).

[33] M. Hildén, F. Groundstroem, T.R. Carter, M. Halonen, A. Perrels, H. Gregow, Crossborder Effects of Climate Change in Finland (In Finnish with English Abstract). Publications of the Government's Analysis, Assessment and Research Activities 46/ 2016, Prime Minister's Office, Helsinki, Finland, 2016.

[34] L. Huovinen, Ruotsin, Norjan ja Tanskan kriisivalmiusjärjestelyt ja niiden kehittyminen 2000-luvulla sekä Pohjoismaisten mallien vertailu, Turvallisuus- ja puolustusasiain komitea TPAK (now Turvallisuuskomitea The Security Committee) Ministry of Defence, Helsinki, Finland, 2009/https://www.defmin.fi/files/1462/ Huovinen Leena 070909.pdf> (Accessed 3 October 2017).

[35] Institute of Seismology, Catalog of Earthquakes in Finland since 2000 (in Finnish with English Abstract), Institute of Seismology. Department of Geosciences and Geography, University of Helsinki, 2017, 〈http://www.helsinki.fi/geo/seismo/ maanjaristykset/suomi.html > (Accessed 8 December 2017).

[36] IPCC, Climate Change 2014: Impacts, Adaptation, and Vulnerability. Contribution of Working Group II to the Fifth Assessment Report of the Intergovernmental Panel on Climate Change, Cambridge University Press, Cambridge, United Kingdom and New York, NY, USA, 2014.

[37] IPCC, Managing the Risks of Extreme Events and Disasters to Advance Climate Change Adaptation, in: C.B. Field, V. Barros, T.F. Stocker, D. Qin, D.J. Dokken, K.L. Ebi, M.D. Mastrandrea, K.J. Mach, G-K. Plattner, S.K. Allen, M. Tignor, P.M. Midgley (Eds.), A Special Report of Working Groups I and II of the Intergovernmental Panel on Climate Change, Cambridge University Press, Cambridge, UK, and New York, NY, USA, 2012, p. 582 http://www.ipcc.ch/report/ srex/.

[38] Å. Johannessen, T. Hahn, Social learning towards a more adaptive paradigm? Reducing flood risk in Kristianstad municipality, Sweden, Glob. Environ. Change 23 (2013) 372-381, http://dx.doi.org/10.1016/j.gloenvcha.2012.07.009.

[39] M.M. Johansson, H. Pellikka, K. Kahma, K. Ruosteenoja, Global sea level rise scenarios adapted to the Finnish coast, J. Mar. Syst. (2012), http://dx.doi.org/10. 1016/j.jmarsys.2012.08.007.

[40] P. Jokinen, Vaarallisia sääilmiöitä Suomessa (Video in Finnish: Dangerous weather phenomena in Finland), 2013. 〈https://ilmasto-opas.fi/fi/ilmastonmuutos/videotja-visualisoinnit/-/artikkeli/6c47483b-d0c5-4702-912a-6ecb14104336/ vaaralllisia-saailmioita-suomessa.html > (Accessed 23 November 2017).

[41] S. Juhola, Mainstreaming Climate Change Adaptation: The Case of Multi-Level 
Governance in Finland, in: E.C.H. Keskitalo (Ed.), Developing Adaptation Policy and Practice in Europe: Multi-Level Governance of Climate Change, Springer, Netherlands, 2010, pp. 149-187, , http://dx.doi.org/10.1007/978-90-481-93257.4 .

[42] S. Juhola, S. Haanpää, L. Peltonen, Regional challenges of climate change adaptation in Finland: examining the ability to adapt in the absence of national level steering, Local Environ. 17 (2012) 629-639, http://dx.doi.org/10.1080/13549839. 2012.665860

[43] K. Jylhä, J. Jokisalo, K. Ruosteenoja, K. Pilli-Sihvola, T. Kalamees, T. Seitola, H.M. Mäkelä, R. Hyvönen, M. Laapas, A. Drebs, Energy demand for the heating and cooling of residential houses in Finland in a changing climate, Energy Build. 99 (2015) 104-116, http://dx.doi.org/10.1016/j.enbuild.2015.04.001.

[44] T. Kekki, T. Mankkinen, Turvassa? Kansalaisturvallisuuden tila Suomessa. Publications of the Government's Analysis, Assessment and Research Activities 8/ 2016, Prime Minister's Office, Helsinki, Finland, 2016 〈http://www.spek.fi/loader. aspx?id = fb3cc0dc-2686-41b0-a046-21e9e6d4c913 $\rangle$.

[45] S. Kellomäki, H. Peltola, T. Nuutinen, K.T. Korhonen, H. Strandman, Sensitivity of Managed Boreal Forests in Finland to Climate Change, with Implications for Adaptive Management, Philos. Trans. R. Soc. B 363 (2008) 2339-2349, http://dx. doi.org/10.1098/rstb.2007.2204.

[46] R.J.T. Klein, S. Juhola, A framework for Nordic actor-oriented climate adaptation research, Environ. Sci. Policy 40 (2014) 101-115, http://dx.doi.org/10.1016/j. envsci.2014.01.011.

[47] M. Komu, K. Hellsten, Luottamus ihmisiin ja luottamus instituutioihin Euroopassa (In Finnish). Nettityöpapereita 12/2010. Kansaneläkelaitos - The Social Insurance Institution of Finland, 2010. 〈https://helda.helsinki.fi/bitstream/handle/10138/ 16514/Nettityopapereita12.pdf?sequence $>$.

[48] V. Kyyrönen, Kokonaisturvallisuus EU:ssa - Suomalainen varautumisen malli Euroopan unionin strategiatöissä, Turvallisuuskomitea (The Security Committee), Helsinki, Finland, 2014.

[49] A. Langley, C. Abdallah, Templates and turns in qualitative studies of strategy and management, in: D.D. Bergh, D.J. Ketchen (Eds.), Building Methodological Bridges, Research Methodology in Strategy and Management, Emerald, Bingley, UK, 2011, pp. 201-235.

[50] H. Laurikainen, Kotitalouksien varautuminen Suomessa. SPEK tutkii 13, Finn. Natl. Rescue Assoc. Spek. (2016) (URL), 〈http://www.spek.fi/loader.aspx?id= 776d58cd-6703-475a-8c91-987ebf9629bb $\rangle$.

[51] A. Mäkelä, I. Lehtonen, K. Ruosteenoja, K. Jylhä, H. Tuomenvirta, A. Drebs, Climate Change in the Capital Area of Finland (in Finnish with English Abstract). FMI Reports 2016:8, Finnish Meteorological Institute, Helsinki, 2016〈https://helda. helsinki.fi/bitstream/handle/10138/170155/PKS ilmastonmuutos.pdf? sequence $=1>$

[52] S. Mikkonen, M. Laine, H.M. Mäkelä, H. Gregow, H. Tuomenvirta, M. Lahtinen, A. Laaksonen, Trends in the average temperature in Finland, 1847-2013, Stoch. Environ. Res. Risk Assess. 29 (2015) 1521-1529, http://dx.doi.org/10.1007/ s00477-014-0992-2.

[53] Ministry of Agriculture and Forestry, Finland's National Climate Change Adaptation Plan 2022 - Government Resolution 20 November 2014. Publication 5b2014, 2014. 〈http://mmm.fi/documents/1410837/5120838/MMM- 193086-v1-Finland s. National climate Change_Adaptation_Plan_2022.pdf/582041ee-3518-4a63-bf607133aed95a9c> (Accessed 4 December 2017).

[54] Ministry of Agriculture and Forestry, Finland's National Strategy for Adaptation to Climate Change. Publication 1a/2005. Ministry of Agriculture and Forestry of Finland, 2005. 〈http://www.mmm.fi/attachments/ymparisto/5kghLfz0d/ MMMjulkaisu2005 1a.pdf> (Accessed 24 April 2012)

[55] Ministry of the Interior Finland, National Risk Assessment 2015. Ministry of the Interior Publication 4/2016, Ministry of the Interior, Helsinki, 2016 (URL) 〈http:// julkaisut.valtioneuvosto.fi/bitstream/handle/10024/64973/National\%20Risk $\% 20$ Assessment $\% 202015$.pdf $>$.

[56] Notre Dame Global Adaptation Initiative: University of Notre Dame. Notre Dame Global Adaptation Index (ND-GAIN Index). URL 〈http://index.gain.org/ > (Accessed 8 December 2017).

[57] K. O’Brien, S. Eriksen, L. Sygna, L.O. Næss, Questioning complacency: climate change impacts, vulnerability and adaptation in Norway, Ambio 35 (2006) 50-56, http://dx.doi.org/10.1579/0044-7447(2006)35[50:QCCCIV]2.0.CO;2.

[58] C. Okereke, B. Wittneben, F. Bowen, Climate change: challenging business, transforming politics, Bus. Soc. 48 (2009) 584-586, http://dx.doi.org/10.1177/ 0007650309345272 .

[59] J. Palme, Pension Rights in Welfare Capitalism: The Development of Old-Age Pensions in 18 OECD Countries, 1930 to 1985, Swedish Institute for Social Research, Stockholm, 1990.

[60] P. Peltonen-Sainio, L. Jauhiainen, K. Hakala, H. Ojanen, Climate change and prolongation of growing season: changes in regional potential for field crop production in Finland, Agric. Food Sci. 18 (2009) 171-190.

[61] K. Pilli-Sihvola, R. Haavisto, V. Nurmi, K. Oljemark, H. Tuomenvirta, S. Juhola, F. Groundstroem, I. Miettinen, H. Gregow, Efficient Weather and Climate Risk Management in Finland (in Finnish with English Abstract). Publications of the Government's Analysis, Assessment and Research Activities 45/2016, Prime Minister's Office, Helsinki, Finland, 2016〈http://tietokayttoon.fi/julkaisu?pubid= 15404>.

[62] K. Pilli-Sihvola, V. Nurmi, A. Perrels, A. Harjanne, P. Bösch, F. Ciari, Innovations in weather services as a crucial building block for climate change adaptation in road transport, Eur. J. Transp. Infrastruct. Res. 16 (2016) 150-173 http://tlo.tbm. tudelft.nl/fileadmin/Faculteit/TBM/Onderzoek/EJTIR/Back_issues/16.1/2016 01a_04.pdf.

[63] K. Pilli-Sihvola, S. Väätäinen-Chimpuku, Defining climate change adaptation and disaster risk reduction policy integration: evidence and recommendations from Zambia, Int. J. Disaster Risk Reduct. (2016), http://dx.doi.org/10.1016/j.ijdrr. 2016.07.010.

[64] P. Pirinen, H. Simola, J. Aalto, J.-P. Kaukoranta, R. Ruuhela, Climatological Statistics of Finland 1981-2010 (In Finnish with English Abstract). FMI Reports 2012:1, Finnish Meteorological Institute, Helsinki, 2012 〈http://hdl.handle.net/ $10138 / 35880>$.

[65] C. Pursiainen, Critical infrastructure resilience: a Nordic model in the making? Int J. Disaster Risk Reduct. (2017), http://dx.doi.org/10.1016/j.ijdrr.2017.08.006.

[66] T. Rantanen, T.C. McLaughlin, T. Toikko, Do Finnish young people support the Nordic welfare state? Int. J. Soc. Soc. Policy 35 (2015) 47-66, http://dx.doi.org/10. 1108/IJSSP-04-2014-0031.

[67] A. Räsänen, A. Jurgilevich, S. Haanpää, M. Heikkinen, F. Groundstroem, S. Juhola, The need for non-climate services - empirical evidence from Finnish municipalities, Clim. Risk Manag. 16 (2017) 29-42, http://dx.doi.org/10.1016/j.crm.2017.03.004.

[68] T. Rauken, I. Kelman, River flood vulnerability in Norway through the pressure and release model, J. Flood Risk Manag. 3 (2010) 314-322, http://dx.doi.org/10.1111/ j.1753-318X.2010.01080.x.

[69] D. Rodrik, Institutions for high-quality growth: what they are and how to acquire them, St. Comp. Int. Dev. 35 (2000) 3-31, http://dx.doi.org/10.1007/BF02699764.

[70] K. Ruosteenoja, J. Räisänen, K. Jylhä, H. Mäkelä, I. Lehtonen, H. Simola, A. Luomaranta, S. Weiher, Climate Change Estimates for Finland on the Basis of Global CMIP3 Climate Models (in Finnish with English abstract). FMI Reports 2013:4, Finnish Meteorological Institute, Helsinki, 2013 〈https://helda.helsinki.fi/ bitstream/handle/10138/42362/2013nro4.pdf?sequence $=1\rangle$.

[71] Sähkömarkkinalaki 588/2013. Sähkömarkkinalaki. 〈http://www.finlex.fi/fi/laki/ alkup/2013/20130588>.

[72] R. Salli, M. Lintusaari, H. Tiikkaja, M. Pöllänen, Keliolosuhteet ja henkilöautoliikenteen riskit. Tutkimusraportti 68. Tampereen teknillinen yliopisto, tiedonhallinnan ja logistiikan laitos. Liikenne ja kuljetusjärjestelmät., Tampere, 2008. (URL) 〈http://www.tut.fi/verne/wp-content/uploads/keliriskit.pdf〉.

[73] J. Samson, D. Berteaux, B.J. McGill, M.M. Humphries, Geographic disparities and moral hazards in the predicted impacts of climate change on human populations, Glob. Ecol. Biogeogr. 20 (2011) 532-544, http://dx.doi.org/10.1111/j.1466-8238. 2010.00632.x.

[74] P. Schmidt-Thomé, Natural and Technological Hazards and Risks Affecting the Spatial Development of European Regions (Special Paper 42), Geological Survey of Finland, 2006.

[75] Security Committee. Security Strategy for Society. Government Resolution 16.12. 2010, 2010. 〈http://www.yhteiskunnanturvallisuus.fi/en/materials〉.

[76] C.M. Shreve, I. Kelman, Does mitigation save? Reviewing cost-benefit analyses of disaster risk reduction, Int. J. Disaster Risk Reduct. 10 (2014) 213-235, http://dx. doi.org/10.1016/j.ijdrr.2014.08.004.

[77] W. Solecki, R. Leichenko, K. O'Brien, Climate change adaptation strategies and disaster risk reduction in cities: connections, contentions, and synergies, Curr. Opin Environ. Sustain. 3 (2011) 135-141, http://dx.doi.org/10.1016/j.cosust.2011.03. 001.

[78] Standard \& Poor's Ratings services, Climate Change is a Global Mega-Trend For Sovereign Risk, 2014. 〈http://maalot.co.il/publications/GMR20140518110900. pdf $>$ (Accessed 8 December 2017).

[79] Statistics Finland, Official Statistics of Finland (OSF): Preliminary Population Statistics [e-publication], 2017. 〈http://www.stat.fi/til/vamuu/2017/09/vamuu 2017_09_2017-10-24_tie_001_en.html〉 (Accessed 4 December 2017).

[80] Statistics Finland, National Accounts, 2017. 〈http://www.stat.fi/tup/suoluk/ suoluk kansantalous en.html $\rangle$ (Accessed 4 December 2017).

[81] Statistics Finland, Koulutus (Education), 2017. 〈http://tilastokeskus.fi/tup/suoluk/ suoluk_koulutus.html (Accessed 4 December 2017).

[82] Statistics Finland, Väestö (Population structure), (2017) 〈http://tilastokeskus.fi/ tup/suoluk/suoluk vaesto.html > (Accessed 4 December 2017).

[83] R.A. Stebbins, Exploratory Research in Social Sciences, Sage University Papers Series on Qualitative Research Methods 48, Sage, Thousand Oaks, CA, 2001.

[84] F. Thomalla, T. Downing, E. Spanger-Siegfried, H. Guoyi, J. Rockström, Reducing hazard vulnerability: towards a common approach between disaster risk reduction and climate adaptation, Disasters 30 (2006) 39-48, http://dx.doi.org/10.1111/j. 1467-9523.2006.00305.x.

[85] UNDP (United Nations Development Programme), Human Development Reports Data, (2016) 〈http://hdr.undp.org/en/data 〉 (Accessed 8 December 2017).

[86] UNISDR, (United Nations International Strategy for Disaster Reduction), Making Development Sustainable: The Future of Disaster Risk Management. Global Assessment Report on Disaster Risk Reduction, United Nations Office for Disaster Risk Reduction (UNISDR), Geneva, Switzerland, 2015 (Accessed 26 November 2017), 〈http://www.preventionweb.net/english/hyogo/gar/2015/en/gar-pdf/ GAR2015_EN.pdf〉.

[87] UNISDR (United Nations International Strategy for Disaster Reduction), Sendai Framework for Disaster Risk Reduction 2015-2030, UNISDR, Geneva, 2015.

[88] UNISDR (United Nations International Strategy for Disaster Reduction), Hyogo framework for Action 2005-2015: Building the Resilience of Nations and Communities to Disasters. Extract from the final report of the World Conference on Disaster Reduction (A/CONF.206/6). UNISDR, Geneva, Switzerland, 2005. (Accessed 25 July 2013).

[89] L. van Well, A. Harjanne, A. Perrels, P. van der Keur, E. Pagneux, H.J. Henriksen, Resilience to natural hazards: an analysis of territorial governance in the Nordic countries, Int. J. Disaster Risk Reduct. (2017).

[90] N. Veijalainen, J. Jakkila, T. Nurmi, B. Vehviläinen, M. Marttunen, J. Aaltonen, Suomen vesivarat ja ilmastonmuutos - vaikutukset ja muutoksiin sopeutuminen (Finland's water resources and climate change - impacts and adaptation), Water.- 
Proj. loppuraportti (2012) (In Finnish) 〈https://helda.helsinki.fi/handle/10138/ $38789>$.

[91] A. Votsis, Space and Price in Adapting Cities: Exploring the Spatial Economic Role of Climate-Sensitive Ecological Risks and Amenities in Finnish Housing Markets (Doctoral dissertation), University of Helsinki, Helsinki, Finland, 2017 (articlebased), 〈https://helda.helsinki.fi/handle/10138/173459〉.

[92] M. Voutilainen, Poverty, Inequality and the Finnish 1860s Famine. Jyväskylä
Studies in Humanities, 287 University of Jyväskylä, Jyväskylä, Finland, 2016 〈https://jyx.jyu.fi/dspace/bitstream/handle/123456789/49598/978-951-396627-0_vaitos13052016.pdf? sequence $=1>$ (Accessed 3 October 2017).

[93] WEF, Global Risks Report 2013, eight ed., World Economic Forum, Geneva, Switzerland, 2013 (Insight report) 〈http://www3.weforum.org/docs/WEF GlobalRisks Report 2013.pdf > (Accessed 17 November 2017).

[94] B. Wisner, P. Blaikie, T. Cannon, I. Davis, At Risk, Routledge, London, 2003. 
Reprinted under the Creative Commons Attribution License 



\title{
Overadaptation to Climate Change? The Case of the 2013 Finnish Electricity Market Act
}

\author{
Väinö Nurmi ${ }^{1,2} \cdot$ Karoliina Pilli-Sihvola $^{1,2}$ (D) $\cdot$ Hilppa Gregow ${ }^{1} \cdot$ Adriaan Perrels $^{1}$
}

Received: 12 June 2018 / Accepted: 27 December 2018 / Published online: 20 February 2019

(C) The Author(s) 2019

\begin{abstract}
In this paper, we put forward a definition of over-adaptation in disaster risk reduction (DRR) and climate change adaptation (CCA) projects. We detail an illustrative case in which the response to extreme weather risk while aligned with the goals of CCA, is implemented beyond the economically efficient scale. We undertake a cost-benefit analysis of the 2013 Finnish Electricity Market Act, enacted partially as a reaction to long, storm-induced electricity blackouts experienced after 2000. The Act imposes strict requirements on electricity distribution companies as regards the duration of blackouts. Meeting these requirements entails investments amounting to billions of euros. As a benefit, we quantify the avoided cost from the blackouts for households and producers. Our results, derived from Monte-Carlo simulations, show that for urban areas, the net expected value is positive. However, in rural areas less strict requirements could have been economically more efficient. Our results indicate that distributional impacts and correspondence between those who benefit and those who pay the costs should be taken into account in DRR and CCA policies that require large-scale investments. We also note that the population affected by a disaster may not accept DRR and CCA that are successful in terms of regulation and implementation. This applies when societal and individual preferences do not coincide.
\end{abstract}

Keywords Economic analysis · Electricity grid · Energy policy Policy assessment $\cdot$ Public good provision $\cdot$ Climate change adaptation

Karoliina Pilli-Sihvola

karoliina.pilli-sihvola@fmi.fi

Väinö Nurmi

vaino.nurmi@fmi.fi

1 Finnish Meteorological Institute, P.O. Box 503, fi-00101 Helsinki, Finland

2 Faculty of Agriculture and Forestry, University of Helsinki, P.O. Box 27, 00014 Helsinki, Finland 


\section{Introduction}

\section{Economic Analysis of Disaster Risk Reduction and Climate Change Adaptation Measures}

Various measures have been implemented or proposed to reduce the impacts of extreme weather events on, and the increasing threat of climate change to, communities, the economy and societies, (e.g. Hallegatte 2009; Konrad and Thum 2014). The goal of such measures is to reduce the exposure and vulnerability of people and assets to natural hazards and climate change and thereby to mitigate their impacts (IPCC 2012). Both climate change adaptation (CCA) and disaster risk reduction (DRR) are cross-cutting policy fields, implying that the respective goals are seldom the only goals of a given sectorial policy or measure. For example, in the public sector, DRR and CCA goals are pursued by first integrating relevant DRR and CCA policy instruments into sectorial policies and then ensuring that the sectorial policy goals are harmonised with the goals of DRR and CCA. (COM 2013; Rivera et al. 2015; Pilli-Sihvola and Väätäinen-Chimpuku 2016).

From an economic perspective, there are several criteria for assessing DRR and CCA policy instruments. The Potential Pareto Improvement (PPI) criterion states that the aggregate level of benefits should exceed the costs (e.g. Freeman et al. 2014). A stricter criterion of Pareto optimality requires optimality in the sense that the aggregate benefits of the policy instrument are maximised by equating the marginal benefits to the marginal costs (e.g. Mendelsohn 2012). Whether these criteria are met can be determined by using cost-benefit analysis (CBA). CBA and cost-effectiveness analysis are traditional tools for determining the economic efficiency of public sector policies and projects (Boardman et al. 2006; Smith et al. 2017) and they have also been used extensively for analysing DRR and CCA measures (Shreve and Kelman 2014).

The aim of this paper is to analyse whether over-investment in DRR and CCA occurs, and how the public reacts to major infrastructure investments whose costs they must eventually bear. In the process, we clarify issues related to applying CBA in CCA- and DRR-related investments. We undertake an in medias res social CBA on the amended Finnish Electricity Market Act, passed in 2013 (588/2013). Among its other goals, the Act seeks to decrease the susceptibility of the electricity network to extreme weather and to make distribution companies adapt to changing weather patterns. This has required major investments in resilient electricity distribution networks. The measures required by the Act sparked an intense public debate, as they were followed by substantial increases in the distribution rates (in Finland, production and distribution are separated), and raised the question of whether the policy was an overreaction from an economic point of view. As a sizable investment in DRR and CCA with quantifiable benefits, costs and uncertainty, the project serves as a good case for using a CBA to evaluate DRR and CCA measures from an economic perspective.

Based on the analysis in Shreve and Kelman (2014), a considerable majority of the costbenefit analyses in the literature have concluded that investing in DRR and CCA measures is beneficial; that is, benefits exceed costs. However, this evidence alone does not warrant the conclusion that DRR and CCA investments are economically efficient and advisable. Indeed, the analysis in Shreve and Kelman (2014) indicates that ex-ante CBAs showing that benefits do not exceed costs are not reported in the literature: no investment was made and no study published. In other words, the CBAs reported suffer from publication bias in that only highly positive or highly negative results have been published (on publication bias, see Easterbrook et al. 1991; Møller and Jennions 2001; in the CBA literature, see Bell et al. 2006) and the hazards studied 
have been based on the ease of calculating the benefits (Shreve and Kelman 2014). The CCA options reported have been almost exclusively favourable ones, although occasional reports of maladaptation have appeared (Noble et al. 2014).

In section "Background to the Case Study", we present the political background of the case study. Second section goes on to provide an economic definition of the case where marginal costs exceed marginal benefits and defines this as over-adaptation. In third section we discuss cost-benefit analysis (CBA) as a method and the data for our case study. Fourth section describes the results and gives a short account of the public reaction to the Act and the public sector's response to this. In fifth section, we consider the limitations of the analysis and prospects for future research. Sixth section concludes with a discussion of the policy implications of the study.

\section{Background to the Case Study}

Finland is a highly developed northern European country where long-term policy and cultural development have averted disasters triggered by natural hazards, (see e.g. Pilli-Sihvola et al. 2017). The Finnish approach to security could be said to exhibit highly risk-aversive preferences (Saastamoinen and Kuosmanen 2016); indeed, they approach lexicographic preferences, with the security of the country and its citizens being the most preferred asset regardless of economic considerations. The major risks are extra-tropical cyclones, winter storms and major snow loads, which cause trees to fall on power lines, resulting in long blackouts. Accordingly, one of the goals of the revised 2013 Electricity Market Act was to reduce the impacts of extreme weather on Finnish electricity consumers with due consideration of the altered weather patterns that climate change will bring. Long blackouts such as those experienced in summer 2010 prompted a need to boost investments in the electricity distribution network, and imposing strict requirements on the permissible duration of the blackouts was considered an effective way to do so (Government Proposal HE 20/2013). The policy process to revise the legislation started quite a bit earlier, in 2001.

The first analyses on the need to reform the legislation were undertaken in 2001. These studies (see Appendix for the list of background studies done prior to the 2013 Act) concluded that the law had to be updated to meet the changing environmental and societal conditions and that it had to include measurable targets. As drafting began, various limits on the length of power outages were assessed. The technology was outdated, and major investments were needed to upgrade it to meet the standards for modern electricity and telecommunication infrastructure and societal structures. Moreover, changes in forest management had increased the exposure of the distribution network to storm and snow damage, and this vulnerability had to be reduced. Two storms in 2001, major thunderstorms in 2010 and heavy snow loads in 2011 (see Fig. 4) highlighted the need to overhaul the distribution network.

The requirements of the 2013 Electricity Market Act are an example of a policy instrument that could substantially reduce the impacts of weather extremes and climate change, for the investments it necessitates would eliminate most of the threat of trees damaging power lines. The Act imposes strict requirements on the duration of blackouts: in rural areas (excluding premises without permanent residents) they should not last no longer than $36 \mathrm{~h}$, and in urban areas no longer than $6 \mathrm{~h}$. The transition period for meeting the requirements extends until 2029, with mid-term goals to be reached by 2019 and 2023 (Electricity Market Act 2013). The upshot of these requirements is that electricity distribution companies have to improve the reliability of their networks, mainly by replacing traditional overhead lines with underground 
ones (Partanen et al. 2012; Saastamoinen and Kuosmanen 2016). The preliminary assessments undertaken prior to the Act indicate that underground cabling is the only way to ensure compliance with the requirements of the Act where the low- and medium-voltage networks are concerned (Partanen et al. 2012). High-voltage power lines in Finland are already weather resilient, as buffer zones are cleared around them.

The three main goals of the 2013 Act (588/2013) are reliability of electricity supply, affordable rates and reasonable service principles (s. 1). The Act contains explicit references to the capability required of the electricity transmission and distribution systems if they are to withstand normal, expected Finnish climate conditions. In this respect, the Act has integrated DRR and CCA needs quite well, and research findings (Gregow et al. 2011) on the changing risk to forests due to climate change were used when the Act was being drafted. The Act (s. 24) also states that transmission rates and conditions need to be equal and non-discriminatory for all consumers. However, the goal of affordable rates for commercial and residential users, justified in terms of strategic goals for economic and social development, partly conflicts with the aims of reliability and reasonable service principles. Compliance with the 2013 Act has required considerable investment on the part of the network companies. The sharp increase in the price of electricity distribution for consumers that followed its enactment led to a major public debate. This and ensuing parliamentary debates, in turn, resulted in the revision of the Act in 2017. The revised Act states that, in principle, price rises should be moderate but that extraordinary costs can justify stronger price increases. The permissible durations for blackouts were not altered. Despite the revision of the Act on 2017, on 28 May 2018, the Ministry of Economic Affairs and Employment, which drafted the Act, ordered an investigation into the price rises and their spatial distribution due to sharp price increases witnessed after the coming into force of the Act.

The ministry commissioned several assessments of the Act during the period 2001-2013. Some of these included economic analyses; for example, Partanen et al. (2006) concluded that a fully underground cable network would be economically feasible only if the avoided cost were 2.5 times higher than the amount estimated at the time of the analysis for a 40-year investment schedule. If the investment had to be made in a shorter time period (for example, prior to 2030, the end of the transition period allowed by the Act), the avoided cost would have to be 5.5 times higher than the estimates at the time. Later, Partanen et al. (2012) concluded that a time limit of $24 \mathrm{~h}$ for blackouts in rural areas, the limit considered initially, would not be economically efficient, and that a 36-h time limit would be preferable. However, the report only compared these two options and their economic feasibility. The legislative proposal (Government Proposal HE 20/2013) included an analysis of the avoided-cost based disutility for the consumers, but did not reach the level of detail of a thorough CBA.

\section{Economic Definition of over-Adaptation to Climate Change}

Climate change adaptation is the process of adjustment to actual or expected climate and its effects. The IPCC defines adaptation as follows: "In human systems, adaptation seeks to moderate or avoid harm or exploit beneficial opportunities. In some natural systems, human intervention may facilitate adjustment to expected climate and its effects". (IPCC 2014). In economic terms, adaptation seeks to reduce the costs related to climate change and, if possible, to turn the negative impacts into positive ones (Tol 2005). CCA can take place at different scales in economics: the economic agents are households, firms and the public sector. This paper focuses on public CCA. Adaptation can also be further broken down into two types, 
anticipatory (planned) and reactive (IPCC 2012; Perrels et al. 2013). In the present case adaptation is cast as anticipatory action resulting in protective investments. However, as discussed in section 1.2, the 2013 Electricity Act (and its induced investments) and revision in 2017 are steps in a learning process, one involving anticipation as well as reaction.

Investments and implementation of CCA measures can lead to three types of sub-optimality: 1) under-adaptation, which implies a lack of adequate CCA in the face of changing climate (Hanemann 2000; Quentin Grafton 2010); 2) over-adaptation, which implies an overreaction to the problem (Hanemann 2000); and 3) maladaptation, which is any action that increases vulnerability to climate change, increases the risk of negative outcomes or diminishes welfare (Barnett and O’Neill 2010; IPCC 2014). Maladaptation has been widely discussed in the literature, and some real-world examples have been presented (Noble et al. 2014). Underadaptation, or inadequate adaptation, has been identified as a potential threat: the actions taken may not be enough to adapt (Quentin Grafton 2010) or, for instance, the private sector may not have adequate incentives to implement CCA measures (Eisenack 2014). However, the literature on over-adaptation is virtually lacking: the only examples of over-adaptation that we were able to find in the literature were the few in Shreve and Kelman (2014), where the benefit-cost ratio of CCA investments was below 1. Despite the clear economic implications of overadaptation, no exact definition of it has been provided to date.

Many CCA decisions concern public policies, public goods or goods with characteristics of such goods (non-rivalry and non-excludability); examples include early warning systems or flood control systems. Optimal CCA for a public good, in terms of partial equilibrium, (e.g. Mendelsohn 2012; OCED, 2018) is to maximise the social net benefits from the provision of the (CCA) good:

$$
\max \sum B_{i}(Q)-C(Q),
$$

where $B_{i}$ is the net present value of the stream of expected value from the public CCA effort such that $B_{i}=\int E V\left(b_{i, t}\right) e^{-r t}, b_{i, t}$ the benefit for individual i at time $\mathrm{t}$, and $\mathrm{Q}$ the quantity of the public good. By differentiating with respect to $\mathrm{Q}$, we get the first order condition for the optimal CCA decision, where $M$ refers to marginal changes:

$$
\sum M B_{i}(Q)=M C(Q)
$$

Thus, at the optimum, the aggregated marginal benefits should match the marginal cost of provision of the public good. Several remarks are in order regarding the optimality conditions. First, in theory, the differences in the social marginal utility of money should be accounted in the aggregation process, a procedure known as distributional weighting. (e.g. Boadway 2006; Johansson-Stenman 2005; Adler 2016; Nurmi and Ahtiainen 2018). Secondly, the quantity of public CCA policy, or Q, is an abstract measure reflecting the scale of the proposed action. In our case study, for example, the quantity of public policy refers to the extent to which the electric grid needs to be renewed in response to the requirements of the Act. A less strict Act would require a lower renewal rate, which could be interpreted as a lower quantity of CCA in this example. In this sense, the quantity itself can be seen as a function of the requirements of the regulation, such that $Q=Q(\boldsymbol{L})$, in which the vector $\mathbf{L}$ represents different characteristics of the regulation. In the present case, these characteristics refer to requirements stipulating the allowable length of power outages in urban and rural areas, as well as to the required uptake schedule. Each of these characteristics can be seen as one dimension of the vector $\mathbf{L}$, which determines the quantity of the public policy. 
The situation we have chosen to analyse is thus far from being a discrete-choice case, in which the only decision would be whether to implement the Act or not. This is true of nearly all public good decisions, such as deciding on the size of a dam (Hallegatte et al. 2012), the scale of proposed green infrastructure to prevent urban storm-water issues (Nurmi et al. 2016; Nordman et al. 2018) or the extent of early warning systems (Holland 2008).

We define over-adaptation as a situation in which a CCA policy instrument and its implementation increase the resilience of individuals and society but lead to a level of adaptation that is not economically efficient. This problem can be defined using a simple formula. Assuming diminishing marginal utility of benefits such that an increase in the quantity of the public good increases the benefits but at a diminishing rate, the formula can be written as follows:

$$
\sum_{i} M B_{i}(Q(\boldsymbol{L}))<M C
$$

If the marginal costs exceed the marginal benefits at some point of provision, less of the public good should be provided; that is, its quantity should be reduced to a level where the marginal benefit equals the marginal costs. However, even at this level of provision, the total benefit of the project can surpass the costs, resulting in a positive benefit-cost ratio or a positive net present value (NPV). This happens if the marginal benefits at lower levels of provision are high enough to compensate for the negative net benefits at higher levels. This situation is depicted in Fig. 1. By contrast, under-adaptation refers to a situation in which the adaptation policy or measure is implemented at a lower-than-optimal level. This is also depicted in Fig. 1.

$$
\begin{gathered}
Q^{1}: \operatorname{Max} B C R\left(Q^{1}\right)=\frac{B^{1}}{C^{1}}>0 ; N P V\left(Q^{1}\right)=B^{1}-C^{1}>0 ; M B>M C \rightarrow \text { underadaptation } \\
Q^{*}: B C R\left(Q^{*}\right)=\frac{B^{*}}{C^{*}}>0 ; \operatorname{Max} N P V\left(Q^{*}\right)=B^{*}-C^{*}>0 ; M B=M C \rightarrow \text { optimal adaptation } \\
Q^{2}: B C R\left(Q^{2}\right)=\frac{B^{2}}{C^{2}}>0 ; N P V\left(Q^{2}\right)=B^{2}-C^{2}>0 ; M B<M C \rightarrow \text { overadaptation }
\end{gathered}
$$

The optimal level of adaptation was derived from equation (2), which states that at the optimum the expected net present value (NPV) is maximised when marginal benefits and costs are at equal level, as in Figure 1 at level $Q^{*}$ and in equation (5).

Another commonly used indicator of the efficiency of a policy or measure is the benefitcost ratio (BCR). For example, Kelman and Shreve (2014) only report the BCRs of DRR and CCA measures, omitting studies that do not report the value. The BCR is a ratio of the net present value of benefits to costs, as shown in equations (4)-(6). As Figure 1 and equation (4) indicate, the ratio is typically highest at a low level of provision (e.g. at $Q<Q^{*}$ ). A low level of provision could correspond to the first systematic efforts to cope with climate change and to elementary disaster risk reduction programmes in developing countries. In Shreve and Kelman (2014), extremely high BCRs are reported for drought reduction measures in the Sudan and flood protection measures in India and the Philippines. Similar results are presented in Onuma et al. (2017a, 2017b), a study showing that experience of a disaster reduces the impact of future 


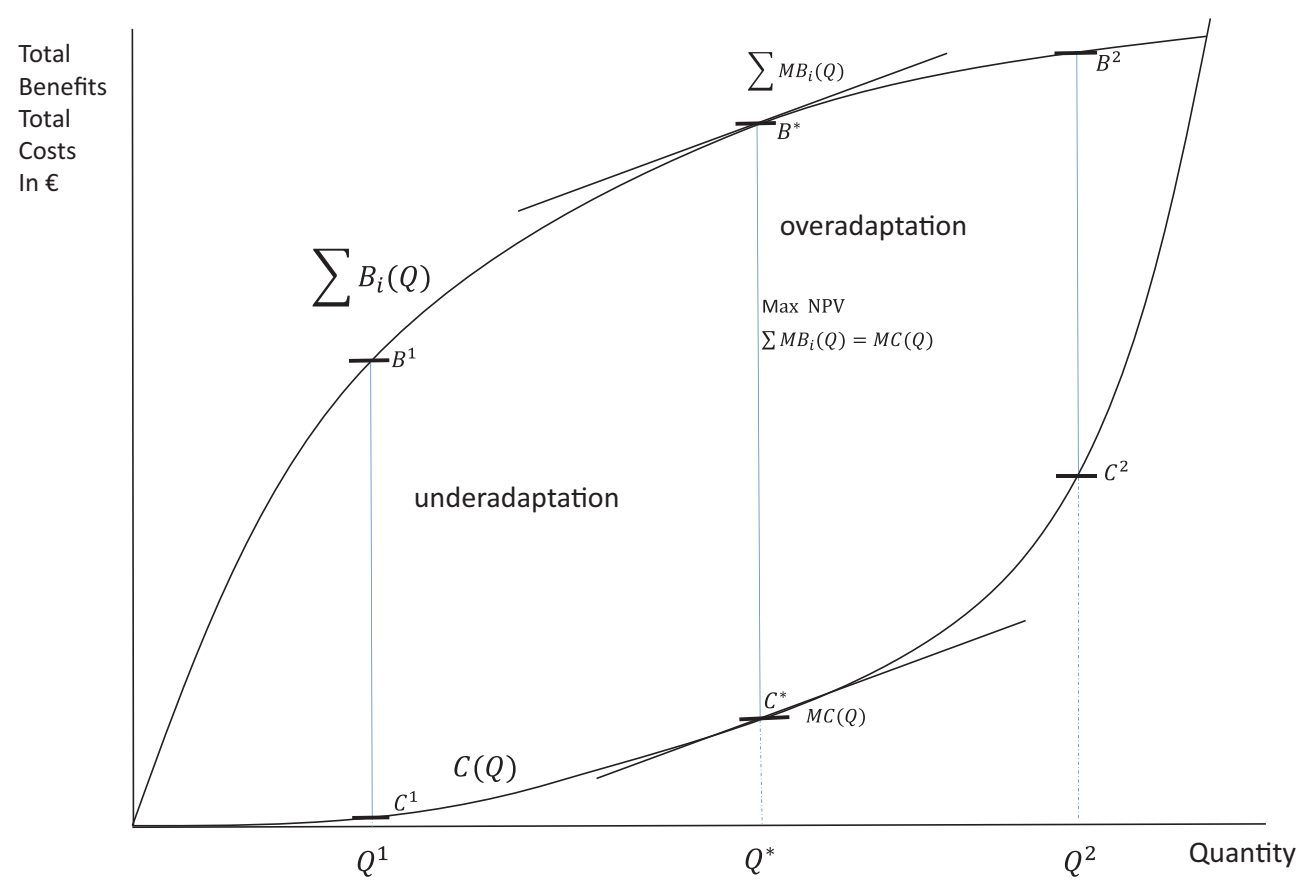

Fig. 1 Optimal adaptation, underadaptation and overadaptation

disasters more in in lower-income than in higher-income countries. However, the optimality of an adaptation policy or measure cannot be evaluated based on the BCR: in Figure 1 the BCR is maximised at $Q^{1}$,which corresponds to underadaptation.

We claim that the lack of evidence of overadaptation in the literature is partly due to the misuse of the BCR as a measure of the efficiency of adaptation instead of the NPV, a more appropriate indicator. The latter should be used where a sufficient number of different provision levels of Q are compared with each other.

CBA practitioners are well aware that NPV is the correct measure when ranking different policy options (e.g. Schwab and Lusztig 1969; Boardman et al. 2006; OECD 2018). If all different provision levels could be evaluated, the option with the highest NPV would represent with the optimal level of provision. In Figure 1 this corresponds to $Q^{*}$. By contrast, the highest BCR would be found at low provision levels and if used as a decision guideline would result in underprovision of the public good. Some caution should also be exercised when interpreting NPVs: if only one or several provision levels are evaluated, a positive NPV in itself only indicates a scale at which total benefits exceed costs. This can occur at levels of the public adaptation good, reflecting either underadaptation or overadaptation, as seen in Figure 1 and in equations (4)-(6). In such a, case, the interpretation of the NPV and BCR coincide, as pointed out by Shreve and Kelman (2014). Sometimes, even in the economics literature, a positive NPV is interpreted as indicating an efficient adaptation effort. (e.g. Mendelsohn 2012), but as explained above, this is not entirely correct. A thorough analysis should include several different provision levels, preferably spanning a wide range of provision. For example, Hallegatte et al. (2012) include three different levels of flood protection in their analysis: i) one medium-sized dam, ii) two smaller dams and iii) one small dam. Provided that the uncertainty in the analysis can be quantified, the option with the highest NPV should be chosen. In addition, when analysing different provision levels, a marginal analysis should be 
conducted at the recommended level of provision to determine whether the net benefits could be further increased by either reducing or increasing the provision level of the focal CCA policy or measure.

Finally, uncertainty is an inherent feature of CCA, so much so that the uncertainty related to climate change adaptation decisions has been termed "deep uncertainty". This can refer to any of three factors: 1) no clear consensus on which models should be used to assess the future, 2) an unknown probability distribution of key parameters and 3) an uncertain value of outcomes (Hallegatte et al. 2012). In such cases, it has been suggested that instead of calculating the expected NPV of investment decisions as a basis for decision-making, robust adaptation strategies should be adopted (Dessai and Hulme 2007; Hallegatte 2009; Hallegatte et al. 2012). These include (Hallegatte 2009) no-regret measures, which create benefits even in the absence of climate change; reversible measures, which are easily retrofitted if climate projections prove incorrect; safety margin measures, which reduce the vulnerability of a system at low or no cost; soft measures, which entail institutional or financial changes; reduced time horizon measures, which involve reducing the lifetime of an investment; and strategies that have synergies with mitigation. Based on the robust adaptation theory, a CBA analysing a CCA policy or measure should include at least a qualitative discussion of the robustness of the proposed actions.

\section{Cost Benefit Analysis for the 2013 Electricity Market Act}

\section{Methodological Issues}

We apply CBA to the reliability requirements of the 2013 Electricity Market Act. We assume cost minimisation for the maximum allowable blackout calculated for a given number of distribution companies in their market areas. As a cost, we include the infrastructure investment in underground cabling required to comply with the Act, calculated based on previous assessments (most notably Partanen et al. 2012). As a benefit, we include the avoided costs of blackouts estimated from blackout data and Willingness-to-Pay surveys and Value-of-LostLoad (VoLL) calculations for industrial users. The Finnish electricity network for low- and medium-voltage lines has been divided into regional monopolies. This being the case, all the costs will eventually be transferred to the customers as an increased rate for electricity distribution, and they will receive the benefits of the Act. The Act will benefit electricity market companies by decreasing their uncertainty relating to compensation costs from blackouts, costs that in the worst case might amount to $30 \%$ of their turnover. (Partanen et al. 2012; Saastamoinen and Kuosmanen 2016). To avoid double counting, we will not consider the decrease in compensation costs as a benefit.

We compare two different levels of provision, urban and rural, as differentiated in the law, and discuss the benefits and costs at the margin. Our results indicate that the Act results in a non-optimal level of provision of public adaptation, a case as yet unreported in the literature.

Smith et al. (2017) point to various factors hindering the use of CBA in many DRR- and CCA-related investments: imperfect valuation methods, sensitivity to assumptions regarding intergenerational preferences (e.g. discount rate), tendency to favour monetised (often tangible market) costs and benefits and inconsistent and often inadequate treatment of non-quantifiable (often intangible non-market) costs and benefits (Atkinson et al. 2008; Boardman et al. 2006; Bonzanigo and Kalra 2014; Florio 2014). In addition, CBA is distributionally insensitive 
(Adler 2013, in DRR CBA see Hallegatte et al. 2016) and often fails to analyse the distortionary effects of raising public funds, reflected primarily as impacts on the labour supply. (Boadway 2006; Bos et al. 2018).

Other methods, partly to overcome the obstacles related to the use of CBA, have been used and developed for assessing optimal investment levels of DRR and CCA measures (Smith et al. 2017; Watkiss et al. 2014). Real-option analysis is used in situations where it may be beneficial to wait before the cost-efficient investments are made, one instance being if the investment would benefit from more accurate information. Portfolio analysis is a tool to determine the efficient frontier of investment options, a point where the NPV of the combination of different options cannot be increased without increasing uncertainty at the same time. Portfolio analysis draws on modern portfolio theory, which is based on the idea of maximising profit and hedging risk by spreading the investment optimally over various assets. Portfolio theory can be used for CCA when a number of measures exist to reduce the risk of climate change and there is uncertainty about the benefits of individual measures. Robust decision making is a decision support method used under deep uncertainty, the purpose being to find CCA measures which will function well under various future scenarios (Lempert and Groves 2010; Lempert et al. 2013; Lempert 2014; Watkiss et al. 2014).

In our case, the reported limitations of CBA are not a major concern. First, the investment period of the infrastructure resulting from the renewed policy is estimated at between 50 and 70 years (Partanen 2015). This timeframe involves intergenerational issues over two or three generations; however, the cost of the capital investment will be paid by the customers and, contrary to what Weitzman (2001) suggests, time-declining interest rates should not be applied. Secondly, our case does not involve any major intangible ecosystem or health costs or benefits, but we have taken into account the value of bare forest land that is freed up as the electricity grid is moved from forest to roadsides. All in all, costs and benefits are relatively easy to estimate, as will be shown in the analysis in a later section.

Thirdly, distributional effects are taken into account in our CBA in two ways. In the first, the average willingness to pay (WTP) is applied for all individuals in the affected population rather than using a higher value for wealthier persons. This is the approach recommended by the European Environmental Agency in health economic studies (EEA 2009) and its theoretical aspects are discussed in Adler (2013). However, in our discussion, we take into account what this implies for the results between different regions. In the second, the spatial distribution of benefits and costs has been taken into account in the policy implications, discussed in section 5.

Fourthly, distortionary effects have been left out of the analysis, as there is no adequate research regarding the labour supply effects of changing electricity prices. Most importantly, no alternative methods to CBA, suggested in Watkiss et al. (2014) and Smith et al. (2017), are needed in our analysis, as the Act is already in force and its implementation is under way. There is no opportunity to wait (a requirement for real-option analysis) and no alternative CCA measures can be used by the companies to meet the requirements of the Act (a requirement of portfolio analysis).

Fifthly, uncertainty related to parameter values is quantifiable and the resulting distribution of net benefits can be simulated with the Monte Carlo method. Monte Carlo simulation is a widely used method for analysing the impacts of uncertainty in the parameter values on the results of a CBA. If this uncertainty could be represented with contingent outcomes, one could simply illustrate the results of CBA using different scenarios. However, in the present case we have many uncertain parameter values, which precludes examining all the combinations of 
values. Our approach is to specify a distribution for each parameter value, take a set of random draws from each distribution, and repeat the trial a number of times. We follow suggestions of Boardman et al. (2006) when specifying the distributions. The resulting histogram can then be used to arrive at statistics about the outcome, such as the expected values and range of NPV and the significance of the results. (Boardman et al. 2006).

Finally, we should point out that our CBA considers implementation costs and directly related avoided costs only. A structural and substantial improvement of the electricity distribution network also has induced economic effects. For example, it may help to keep some residents and economic activity in the service area. Furthermore, some of the avoided costs represent actual expenditures rather than inconvenience costs, and these funds can be reallocated for consumption, creating more welfare. Then again, if prices rise more than consumers are willing to pay in a given area, this will create negative effects in the form of reduced purchasing power and areas becoming less attractive places to live. We disregard these spillover effects in the secondary markets in our CBA (Boardman et al. 2006) but discuss them in section 5 , as they may be relevant information for cross-cutting policy goals.

\section{Analysis}

\section{Estimation of Benefits for Household Consumers}

Various methods are used to monetise the increase in the utility from an improvement in the quality or quantity of a good for individuals in society. Direct methods include contingent valuation, indirect ones travel cost or hedonic pricing. The disutility of a blackout for consumers is usually valuated using contingent valuation surveys, which elicit the willingness-to-pay (WTP) to avoid a blackout or willingness-to-accept (WTA) compensation for one.

The most recent such survey in Finland was carried out in 2014 (Matschoss 2014). Rather than the cost per unit of time, the survey asked respondents about their cost per value of lost load (VoLL). In our view, lost load is a harder concept for household consumers to understand than hours without electricity, but in the international literature VoLL is the standard method for reporting the cost of blackouts. However, surveys designed around VoLL often use questions related to inconvenience per time unit (London Economics 2013) and this can be directly converted to cost per time unit. As the average consumer in Finland uses approximately one kilowatt hour of electricity per hour, the VoLL per kilowatt hour is essentially the same as the cost of one hour without electricity.

Converted into hours of blackout, the average VoLL figures in Matschoss (2014) were WTP $1.5 € / \mathrm{h}$ and WTA $15 € / \mathrm{h}$. These were assumed to be linear over the duration of the blackout. The high disparity between WTP and WTA suggests behavioural anomalies; the income elasticity of WTP in the study was unrealistically high at 18. The tenfold difference between the WTP and WTA implies that a consumer would not accept 14 euros in compensation for a one-hour blackout that he or she experienced, yet would not be willing to pay two euros to avoid the same blackout. Given such behavioural anomalies (e.g. Kahneman et al. 1991), these values are not directly applicable in a CBA. The responses to the WTP surveys also suggest that consumers do not necessarily support the lexicographic preferences adopted in national-level decision making (see section 4.4). Interestingly, the high divergence between WTP and WTA in the surveys suggests that an ownership effect obtains among consumers with regard to their right to undisrupted electricity consumption. (London Economics 2013). 
London Economics (2013) gathered international estimates for the costs of blackouts to households, and estimated VoLL figures in the UK. The range of WTP estimates in the literature is very wide. The smallest WTP for a one-hour blackout was $0.4 € / \mathrm{h}$ (Carlsson and Martinsson 2008). Accent et al. (2008) obtained a value close to $30 € / \mathrm{h}$. The WTP values in London Economics (2013), only about $1 € / \mathrm{h}$. are significantly lower than those in Finland. The WTA values reported, which ranged from 4 to $8 € / \mathrm{h}$ under different conditions, are closer to the Finnish estimates.

We apply two different methods to estimate the level of benefits that domestic consumers and industry obtain from the Act. For domestic users, the benefits are evaluated based on the duration of the avoided blackouts. The monetary benefits are estimated by combining the two Finnish contingent valuation surveys (Silvast 2005; Matschoss 2014) and values reported in the international literature (London Economics 2013). We drop the two lowest and two highest outliers in determining the range of WTP values; this yields a lower bound of $1.5 € / \mathrm{h}$ (Matschoss 2014) and an upper bound of $15 € / \mathrm{h}$ (Accent 2004), all converted into €2015.

The discrete time periods and amounts of lost energy consumption used in the literature have been scaled into a continuous model using the results of Silvast et al. (2005), who drew on a range of blackout durations to create a model very close to a continuous model. The study also provides a detailed description of the Finnish context. According to Silvast et al. (2005), the cost of the first second of a blackout for a household consumer is, on average, 1.7 euros in winter and 1.8 in summer; for a 36-h blackout the values are 368.7 euros and 366.5 euros, respectively. As the costs of blackouts between these two extremes were almost linearly distributed, we fitted a simple linear model (Table 1):

\section{Estimation of Benefits for Industrial Users}

We estimate the benefits for industrial users using the production function approach. VoLL is the appropriate measure as it allows scaling for the volume of production, reflecting the fact that the cost of a blackout of a particular duration is not the same for industrial users of different sizes. Table 2 below presents estimates of the loss of value-added production for different industries based on national statistics and recently updated by the Finnish Energy Authority (2015) using values reported in Mäkinen et al. (2009). In the table, VoLL $€ / \mathrm{kW}$ is the value of production lost due to a disruption (of any duration) in the supply of electricity and $€ / \mathrm{kWh}$ the value of production lost based on the entire duration of the blackout.

Statistics Finland (2014a) gathers statistics about the use of energy in different sectors. Within the sectors, companies are classified based on their turnover. For example, in the agricultural sector, $99 \%$ of the companies are small, having turnovers of less than $€ 100,000$. The average energy consumption for such a company is $20,000 \mathrm{kWh}$ per year, or $2.3 \mathrm{kWh} / \mathrm{h}$, and the average power is $25 \mathrm{~kW}$. The power and electricity use have also been calculated for the chemical, paper, metal and mining sectors. Only companies with a turnover less than $€ 400,000$ have been included in the above figures. Large facilities, whose turnover and consumption are greater, obtain their electricity directly from the high-voltage grid, which is a weather resilient.

Table 1 Output of the linear regression model

\begin{tabular}{llll}
\hline & Estimate & Std. Error & t-value \\
\hline Intercept & 9.8702 & 5.3269 & 1.853 \\
Length in hours & 10.1395 & 0.3138 & 32.314 \\
\hline
\end{tabular}


Table 2 VoLL for Finnish industrial users (Energy Authority 2015) and agriculture (Honkapuro 2006)

\begin{tabular}{lll}
\hline Sector & VoLL $€ / \mathrm{kW}$ & VoLL $€ / \mathrm{kWh}(€ 2015)$ \\
\hline Mining & 0.44 & 0.27 \\
Paper and wood & 2.60 & 0.23 \\
Chemical industry & 2.40 & 2.00 \\
Metal industry & 2.02 & 0.98 \\
Agriculture & 0.45 & 9.38 \\
\hline
\end{tabular}

\section{Estimation of Benefits from Reclaiming Bare Forest Land}

Underground cabling brings ecosystem benefits. For instance, one company in our data set estimates that in 2016, 800 ha of what had been mainly forested land became made available when overhead lines were removed, and estimates that in the future the figure will be 1000 ha annually (Caruna 31.10.2017). This would correspond to approximately 2000 ha/year in our study area. To quantify these benefits, we use the figures from Tahvonen et al. (2013), who calculated the value of cleared forest land assuming optimal rotation periods. For an optimal land type in the study area, the value at a discount rate of $3 \%$ corresponds to $447 €$ per hectare; when the rate approaches $5 \%$, the value per hectare approaches zero. For a less optimal land type, the corresponding values are very low, $38 €$ and $-177 €$. We assume that in the case of negative values, the land will not be used for forestry; a minimum value of 0 and a maximum value of $€ 447$ per hectare is used in the Monte Carlo simulation. These values are already discounted for future profits. The benefits will be realised during the renewal phase of the network, a period spanning 15 years.

The length of power lines will increase due to their relocation from forest to roadsides. It has been estimated that in rural areas the increase in length will be 1.1 times for the lowvoltage network and 1.2 times for the medium-voltage network. (personal communication, Karvonen 2018). In the Monte-Carlo simulation, we specify a distribution with a range between 1.0 and 1.2 for the low-voltage network and between 1.1 and 1.3 for the mediumvoltage network.

\section{Estimation of Costs}

As noted above, compliance with the requirements of the Act requires a high level of investment in the case of both the low- and medium-voltage networks (Partanen et al. 2012). In particular, a significant proportion of the electricity network laid underground. To quantify the costs, we need to know the i) current extent of underground cabling, ii) required extent of underground cabling and iii) length of the network in rural and urban areas and iv) costs of underground as opposed to overhead lines. Partanen et al. (2012) present estimates of the required level of underground cabling in rural areas, where underground cabling of medium- and low-voltage networks are partial substitutes for each other; that is, by increasing the proportion of underground cabling in one network, the proportion can be decreased in the other, but at a diminishing rate.

Figure 2 illustrates the requirements for underground cabling rates in rural areas for the electricity distribution companies included in the analysis of Partanen et al. (2012). The set of companies is not the same as that in our analysis, but the same cabling rates are assumed to apply. Each coloured line represents the required rate for one company, and the dots describe the current extent of underground cabling. For instance, if the cabling rate for the low-voltage 


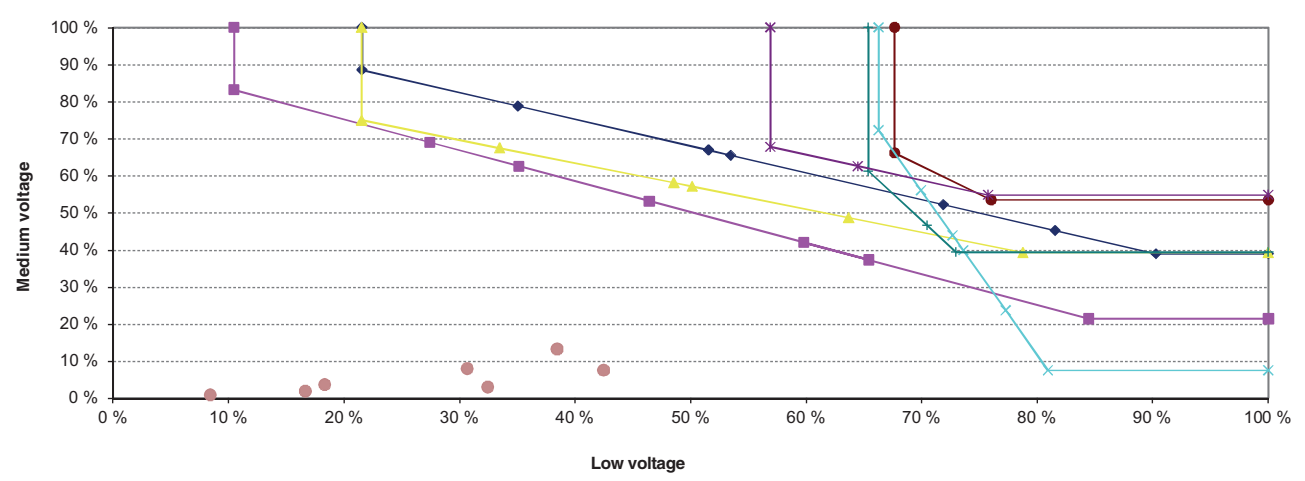

Fig. 2 Required level of underground cabling for seven electricity companies in rural areas (graph from Partanen et al. 2012)

network is $35-45 \%$, the rate for the medium voltage network must extend to $50-80 \%$; if the cabling rate of the low-voltage network is $70-90 \%$, the rate of the medium-voltage network needs to be between 20 and $60 \%$, depending on the company. These rates would make it possible to meet the $36-\mathrm{h}$ blackout limit. In urban areas, a $100 \%$ underground cabling rate is required for both the low- and medium-voltage networks to ensure compliance with the 6-h limit.

In our analysis, we assume that the companies choose the level of cabling that i) meets the requirements and ii) is the cheapest to produce. In other words, they comply with the Act but in a cost-efficient manner.

\section{Data}

To evaluate the increased reliability of the electricity grid, we need data on the current and expected blackouts in the analysed region. In Finland, electricity distribution companies are required to collect blackout statistics. The annual statistics are published by the Finnish Energy, an umbrella organisation of the energy companies in Finland, but the data are available only as an aggregate for all 80 companies operating in the country. To overcome this obstacle, we purchased raw data for eight companies from a private consultancy firm that analyses data for Finnish Energy (ENEASE 2016). This data set is also aggregated such that no individual company can be identified. However, we know the companies in the set and are able to analyse their network status. In addition to blackout data, we need the rate of underground cabling and customer information, which are provided by the Energy Authority (2015). Significantly, the operating areas of the companies form a single, representative region for which we can also analyse the weather and climatic conditions now and in the future.

The region encompasses Pirkanmaa region in south-western Finland as well as surrounding areas served by the electricity distribution companies operating in Pirkanmaa. The sample covers over $30 \%$ of the consumers in Finland, has both rural and urban areas in approximately the same proportion as the rest of Finland, and contains both large and small companies. Some of the companies are very small and local. Table 3 shows the distribution of consumers between different industries and household consumers among the eight companies.

For the costs, we need to know i) the present rate of underground cabling, ii) the length of both the low- and medium-voltage networks for all the operators, divided between urban and rural users, and iii) the costs of underground cabling for a unit of $(\mathrm{km})$ of network. 
Table 3 Users of the electricity grids in the study area

\begin{tabular}{llllll}
\hline $\begin{array}{l}\text { Division of different } \\
\text { user groups }\end{array}$ & Agriculture & Industry & $\begin{array}{l}\text { Services and } \\
\text { construction }\end{array}$ & Households & Total \\
\hline Share \% & 0.6 & 0.6 & 0.6 & 98.2 & 100 \\
Amount & 6600 & 6600 & 6600 & 080200 & 100,000 \\
\hline
\end{tabular}

The current level of cabling is public knowledge, provided in the annual reports of electricity companies. (Energy Authority 2015). These are shown for the eight companies in the area in Figure 3. The y-axis marks the current rate of medium-voltage underground cabling, and the $\mathrm{x}$-axis that of low-voltage underground cabling.

In the areas studied, the total length of the medium voltage network is $52,528 \mathrm{~km}$, and of the low-voltage network 99,708 km. (Energy Authority 2015).

Lastly, we need to know the average costs for both the low- and medium-voltage networks. Partanen et al. (2012) estimate for the medium-voltage network that underground cabling is two times more expensive than traditional overhead power lines, the costs being $61,700 € / \mathrm{km}$ compared to 28,800-32,200€/ km. Based on the data from the Energy Authority $(2011,2014$, 2016), a substantial decrease in the costs has occurred only in the case of the heaviest cables; the costs of other types and the average costs have remained almost constant. No substantial learning effects and resulting decrease in costs are expected, as thousands of kilometres of underground cables have already been installed.

For the low-voltage network, the difference in the costs between underground cabling and overhead lines in rural areas is smaller, approximately $3000 € / \mathrm{km}$, the figures being 21,000 $€ / \mathrm{km}$ and $18,000 € / \mathrm{km}$ respectively. Data collected from the electricity grid companies indicate that in urban areas the costs are again nearly twice as high for underground cabling, or 34,000 $€ / \mathrm{km}$ compared to $18,000 € / \mathrm{km}$ (Energy Authority 2016). The difference is explained by the more expensive digging costs in urban areas.

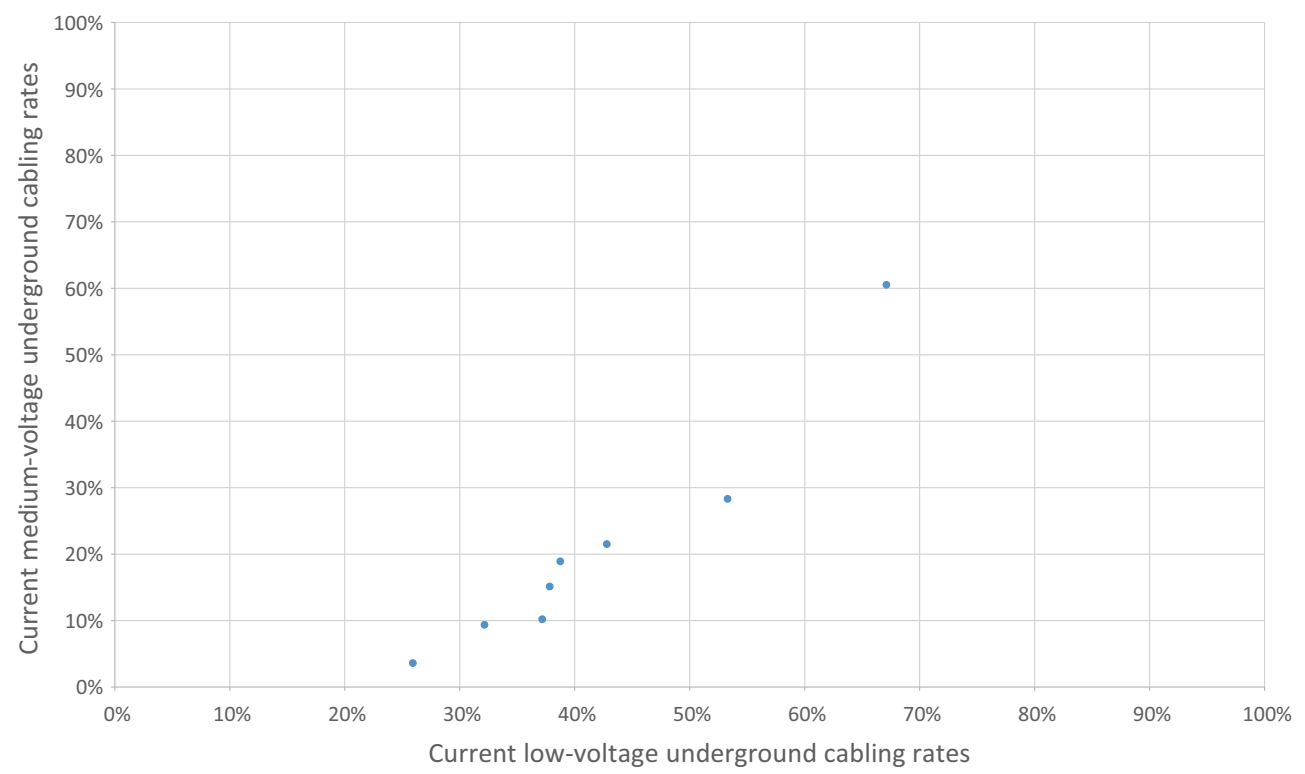

Fig. 3 The current state of the electricity network (Data from Energy Authority 2015) 
The blackout data cover the 10-year period from 2005 to 2014, which includes the years 2011 and 2013 that saw storms causing long blackouts in the study area. The return period for such storms cannot be estimated with current knowledge, as gust winds cause most of the major damage to trees - and most blackouts - but the measurement period for such winds has not been not long enough to produce return period estimates for a particular location.

Significantly, both the 2011 and 2013 storms occurred when the soil had yet to freeze. When the depth of soil frost extends less than $20 \mathrm{~cm}$, trees are not properly anchored to the ground and are thus very susceptible to uprooting (Gregow et al. 2011). As we are interested in the benefits of improving the reliability of the electricity grid in the future (time span 0 60 years), we have to consider the effects of climate change on weather phenomena, soil conditions and vulnerability of the sites affected.

First, we consider the current climatic conditions in the area of concern, that is, Pirkanmaa and surrounding areas, meaning southern, southwestern and central Finland. The current blackout risk can be calculated based on the 2005-2014 time series, which represents the degree of variability in the Finnish climate and the distribution of blackouts between years well (Figure 2). For the future climate, we first take a single-parameter approach. For extreme winds, the model estimates from the EU FP7 project Rain (Groenemeijer et al. 2016) show that extreme winds with an annual exceedance probability of 2\% in 1971-2000 will have a probability of 2.5\% in 2021-2050 over southern and southwestern Finland. For 2021-2050, there is not much difference between different climate scenarios. From 2071 onwards, climate scenarios have a much greater impact on the annual high wind gust probabilities, but this falls largely out of the scope of our time frame. Annual blizzard probability is decreasing in southern Finland according to all climate scenarios. We can conclude that changes in gust wind or blizzards will not in themselves increase the risk of blackouts. An additional risk to the electricity grid to consider, however, is crown snow load, which is projected to increase in major parts of the country under all climate scenarios and time periods. However, the model results are not statistically significant at the $95 \%$ level except for the high-emission scenario RCP8.5 in 2071-2100 in southern Finland, where the results indicate a decreasing risk. (Groenemeijer et al. 2016).

Secondly, we assess the risk induced by climate change and its impact on soil frost (Gregow et al. 2011). These results suggest an increase in the risk of trees being uprooted, even if changes in the wind speeds do not occur. Gregow et al. (2011) indicates that the number of days when tree anchorage is poor will increase will from around 95 (1971-2000) to 185 days (2040-2065) in southern Finland; in other words, the risk of uprooting will nearly double. In central Finland, the corresponding numbers range from 90 to 125 days, implying a $40 \%$ increase in risk. However, we remain cautious in using these estimates, the increased risk has already been, to some extent, realised in our data due to the major storms in autumn and winter 2011 and 2013, which occurred with little or no soil frost.

Thus, we combine the increasing soil frost risk with the concurrent occurrence of strong winds and snow loads to describe the storm impact risk. As presented in Gregow et al. (2011 pp.48, Table 6), the risk of uprooting in the spruce-dominated areas in southern Finland will increase by $18 \%$ by $2046-2065$ when using a SREX climate scenario A1B (Nakicenovic et al. 2000). This corresponds to RCP6.5 or RCP8.5 (Rogelj et al. 2012), depending on the period in question. In Jyväskylä, which reflects the conditions in central Finland, the projected increase is $13 \%$. While these estimates do not include changes in tree species or forest management by 2050, they do give an indication of the economic risk lying ahead in the spruce-dominated regions of southern and central Finland. 
In our analysis, we combine this information with the current risk of weather-induced blackouts. The low-end estimate of the future blackout estimate is based on the low-emission scenario, in which the conditions that led to blackouts in 2005-2014 do not change. In the medium- to high-end estimate, we use the risk level indicated by the high-emission scenarios, leading to a $13 \%$ to $18 \%$ increase in risk by 2045 . We assume a linear increase in the risk and extrapolate the increase for the remaining period 2045-2075. This leads to an asymmetric distribution for the annual increase in the risk ranging from 0 to $0.6 \%$.

\section{Results}

In a cost-benefit analysis, the timing of both the benefits and costs needs to be analysed and discounted to present value. This requires numerical parameter values, which we have obtained from various sources to analyse the costs and benefits as well as the uncertainties, in particular those affecting the benefits. Additional parameters affecting the uncertainty regarding future benefits are the rates of urban and rural population growth. Most underground cabling will be done in rural areas, but with Finland still undergoing rapid urbanisation this might affect the future benefits of the investment.

\section{Benefits}

The average annual number of weather-related blackouts was 34,360 in the study area, affecting on average 107 customers. As an aggregate, the consumers faced approximately 3,642,000 blackouts annually. The average length of a blackout was 3 h 20 min. Figure 4 shows the yearly number of blackouts.

We calculate the benefits by assuming that the requirements of the Act are achieved, thus assuming that the electricity network is upgraded according to the requirements of the Act. We divide the household users into urban and rural users (Statistics Finland 2016). In urban areas, we assume that no weather-related blackouts will occur as the underground cabling rate will be increased to $100 \%$. This results in annual benefits of 4.7-49 million $€$ (with mean 19.9 million $€$ ). In rural areas, we assume that the blackout frequency will be halved (as about 50\% more of

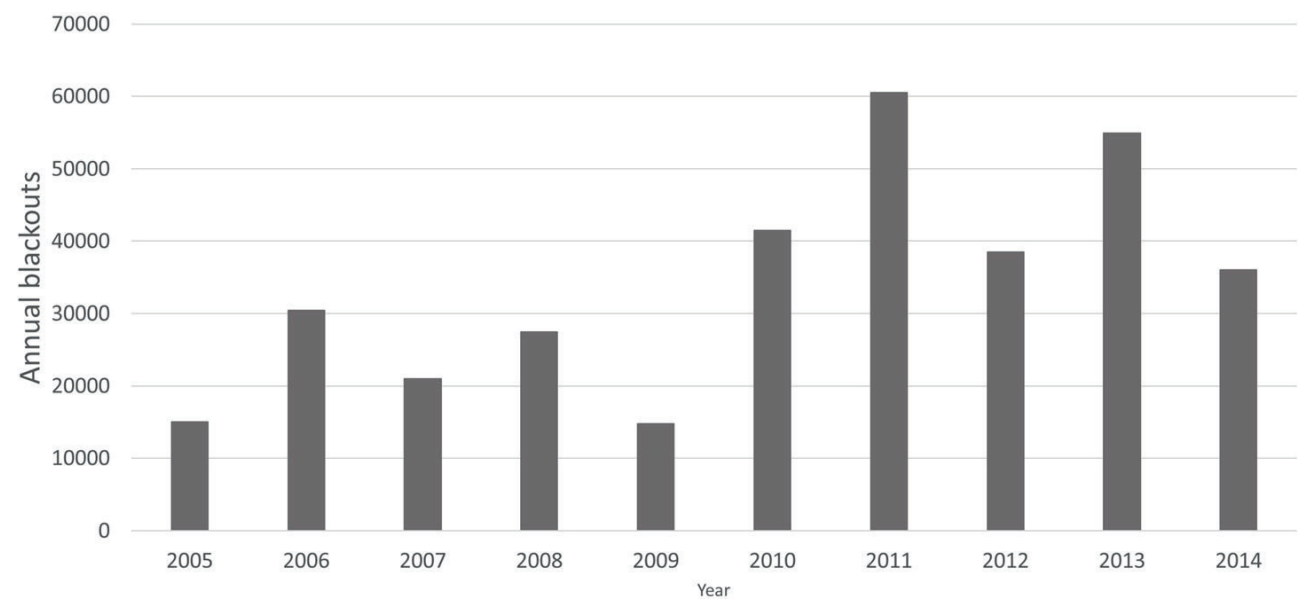

Fig. 4 Weather related blackouts in the study area in 2005-2014 
the network will be laid underground) and that no blackouts longer than $36 \mathrm{~h}$ will occur. This results in annual benefits of 6.8-70.9 million $€$. The wide range in both cases is due to the high disparity between the WTP figures reported in the literature. However, the triangular distribution fitted to the range of WTP figures has more probability mass for the values closer to the mean. The benefits are reported in 2015 euros.

For commercial users, we use the VoLL values shown in Table 2. Complementing these, we have collected data on a typical company in each sector and its power and annual electricity use (Statistics Finland 2017). As there are no data on the exact proportions of urban and rural industries, we use the more conservative assumption that the frequency of the blackouts will be halved. The projected benefits for each sector are shown in Table 4. Each sector included contains different subsectors, such as the food industry, wood industry and support services for mining, but as yet there is no VoLL available for sub-sectors separately.

Based on our analysis, the commercial benefits account for some $5 \%$ of the total benefits. In the international literature, the total damage costs to industry from blackouts is estimated at around 10\% (LaCommare and Joseph 2004). The difference stems from our case as we have taken into account only the small and medium sized industries. In Finland, large companies and industrial facilities are connected to the high voltage network and are outside the scope of this analysis.

\section{Costs}

In urban areas, the rate of underground cabling for both the low- and medium- voltage networks must be $100 \%$ to meet the requirements of the Act. The current rate for the lowvoltage network is around 70\%, and for the medium-voltage network 50-60\%. (Energy Authority 2015; Finnish Energy 2014). The investment cost for the former is 190-218 million $€$ and for the latter 160-182 million $€$. For both networks, we further assume that $50 \%$ would have to be renewed in any case as part of scheduled maintenance, and 50\% would have to be laid underground prematurely. (Partanen et al. 2012).

The underground cabling rates for low- and medium-voltage power lines are partial substitutes in rural areas: increasing the rate in one network could lead to a decrease in the rate required in the other. Underground cabling of the low-voltage network is much cheaper, whereby the most cost-efficient approach is to increase the proportion of underground cabling until it no longer compensates the lower rate in the medium-voltage network. This rate (Partanen et al. 2012; Figure 1) is around $80 \%$. Thus, we assume that in rural areas the underground cabling rate of the low-voltage network will be $80 \%$. The required rate for the

Table 4 Benefits for commercial users

\begin{tabular}{lllll}
$\begin{array}{l}\text { Chemical } \\
\text { industry }\end{array}$ & $\begin{array}{l}\text { Wood } \\
\text { and Paper } \\
\text { industry }\end{array}$ & $\begin{array}{l}\text { Metal } \\
\text { industry }\end{array}$ & Mining & Agriculture \\
\hline 600 & 300 & 1500 & 150 & 5450 \\
3.3 & 3.3 & 3.3 & 3.3 & 3.3 \\
3.37 & 3.37 & 3.37 & 3.37 & 3.37 \\
2090 & 1770 & 1560 & 350 & 110 \\
1260 & 530 & 2300 & 50 & 600 \\
630 & 270 & 1150 & 25 & 300 \\
$410-840$ & $180-360$ & $770-1560$ & $17-34$ & $200-400$ \\
\hline
\end{tabular}


medium-voltage network becomes 20-50\% (Partanen et al. 2012; Figure 1), leaving a high uncertainty range. An additional consideration is that the length of the electricity network is assumed to increase, as noted earlier (personal communication, Karvonen 2018). Ultimately, the total cost of meeting the requirements of the Act in rural areas will be 570-1460 million $€$. The wide range is due to the uncertainty in the required underground cabling rate, which depends on other measures to improve the network. A second source of uncertainty is the increase in the length of the low-voltage and medium-voltage networks when cables are removed from forested land and relocated to roadsides.

\section{Parameter Values}

Consumers of electricity obtain the benefits as soon as the investments have occurred and receive the benefits as long as the underground cables are used. For the distribution companies the investment costs are incurred immediately, but for consumers the cost is carried in keeping with the write-off schedule (typically a 30-year straight line-depreciation) and the capital cost of the investment. Consequently, the consumer benefits must exceed at least the weighted average cost of capital (WACC). In 2014, the WACC for electricity networks was 3.2-4.5\%. (Äijälä et al. 2014; Ernst and Young 2014) but the cost of external financing has since decreased by $0.5-1 \%$ (Bloomberg 2016). For the low end of the discount rate, we use $3 \%$. For the expected value, we use the average 12-month Euribor rate (since the euro area was established and Finland joined it in 2002) plus the current rate; for the high end, we use the highest Euribor rate plus the current cost of borrowed capital. It should be noted that economists (Weitzman 2001) recommend using a time-declining discount rate; in the present case, however, the benefits should be discounted by the cost of capital, as this will also be borne directly by the consumers. In estimating rural and urban population trends, we use projections calculated by the United Nations for Finland. WTP values were derived in section 3.2.1. The costs depend on the required underground cabling rates, as explained in section 3.2.3. Table 5 shows the ranges for the parameter values and their source.

\section{Monte Carlo Analysis and Net Present Value}

We ran a Monte-Carlo simulation with the above parameter values and distributions using the Palisade @ Risk for Risk Analysis (2018) add-in to Microsoft Excel statistical software. The simulation was run 1,000,000 times. The NPV of the benefits was estimated separately for improvements in the urban and rural networks. Figure 5 depicts the resulting distribution for urban areas. NPV is positive at the 95\% significance level. The mean of the NPV distribution is 158 million euros. Of the variance in the NPV, the discount factor explains $86.1 \%$; costs, $1 \%$; WTP, $12.5 \%$; and the urban growth rate, $0.4 \%$.

Figure 6 shows the corresponding distribution for rural areas. The mean NPV is -374 million euros. There is a $96.2 \%$ probability that the NPV is negative in rural areas. In a noteworthy difference compared to urban areas, in rural areas the uncertainty in the costs of improving the network has a much larger effect on the variance of the NPV. This uncertainty explains $73.8 \%$ of the variance, while the discount factor explains only $21.6 \%$. Other factors explaining the variance include the uncertainty in the true value of WTP $(4.3 \%)$ and the decrease in the rural population $(0.3 \%)$.

To summarise, the expected NPV in urban areas is 158 million $€$, and in rural areas -374 million $€$. The expected benefits for industrial and agricultural users are 110 million $€$. To 


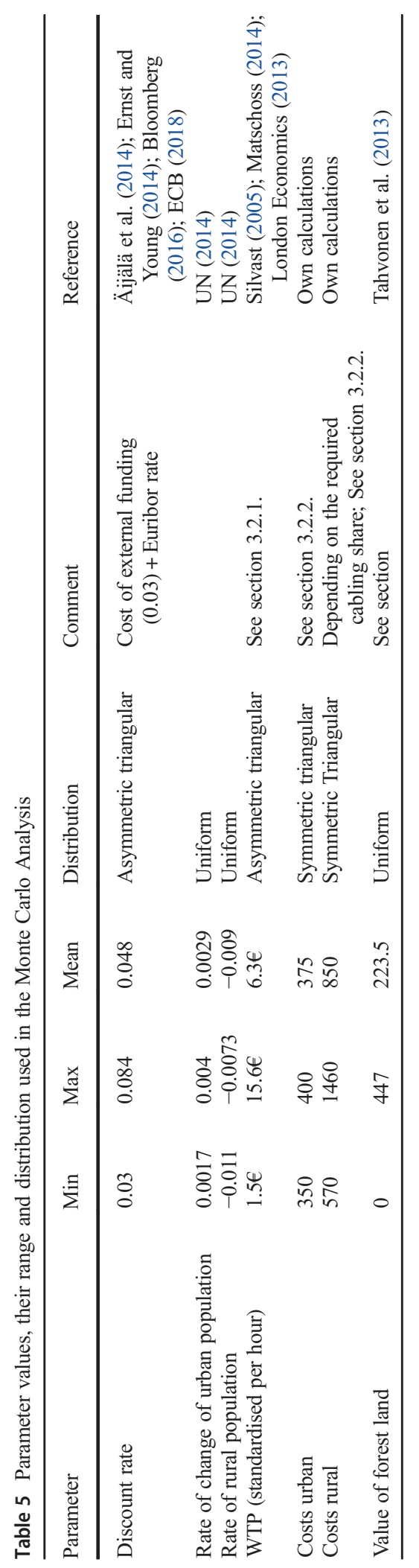




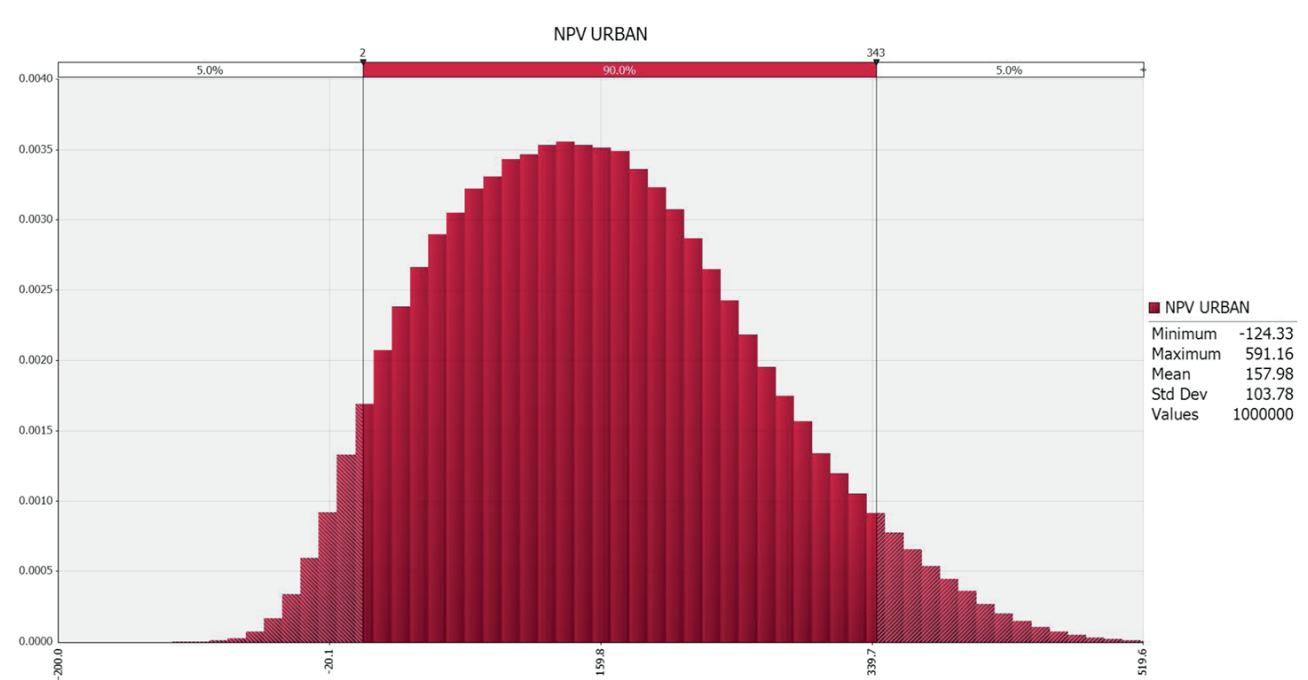

Fig. 5 The distribution of NPV for the urban areas

avoid double-counting, as the costs are already taken into account in the urban and rural analysis, the 110 million euros are added to the aggregate NPV, resulting in total expected NPV of -106 million euros.

The division of NPV between urban and rural areas only refers to the spatial component of the benefits and costs, not to the relative proportion of the investment costs ultimately borne by urban and rural consumers. In fact, if the electricity price increase is spatially uniform, urban customers $(85 \%$ of the population) will bear most of the total cost $(85 \%$ assuming uniform electricity use and prices), while the majority of the benefits will go to the rural areas (expectation $40 \%$ vs. $60 \%$ ). However, if an electricity company operates only in a rural area, rural customers will pay all the costs, most likely resulting in greater rate increases than the customers are willing to pay. Clearly, at the margin, in rural areas the costs are higher than the benefits.

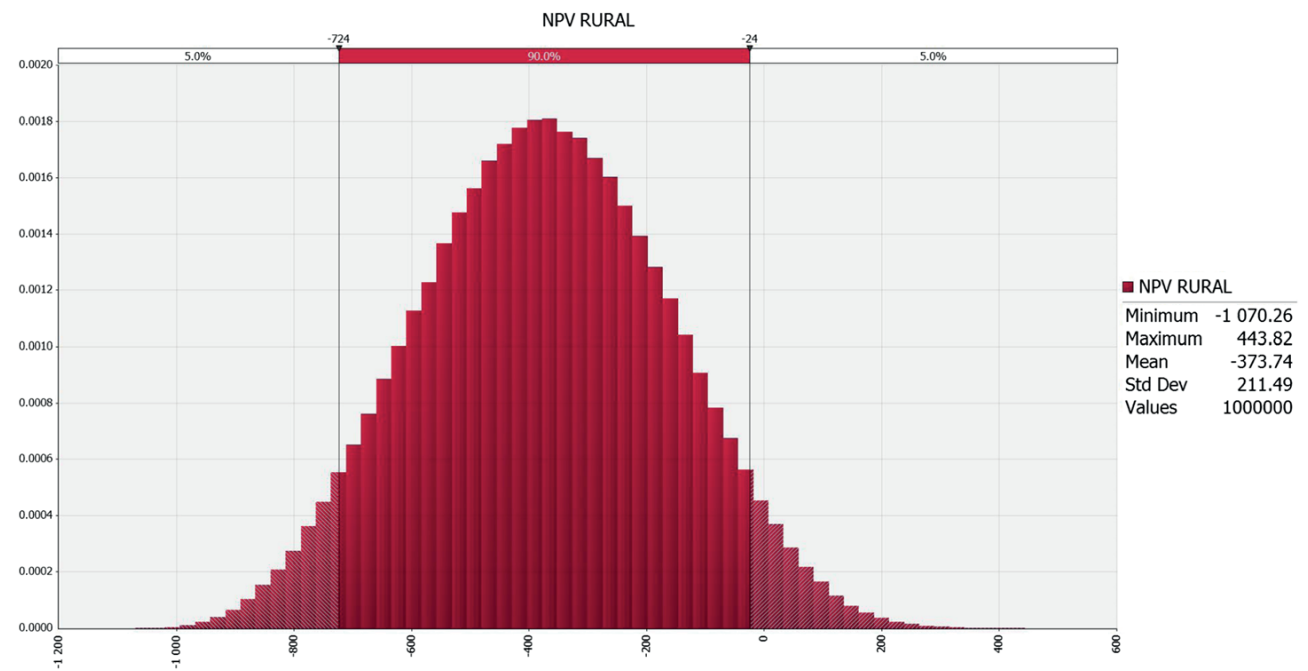

Fig. 6 The distribution of NPV for urban areas 
To further analyse the spatial distribution of the benefits and costs, we can divide electricity grid companies into three different categories, examples of which exist can be found in our data: 1) those operating only in rural areas, 2) those operating in both rural and urban areas and 3 ) those operating only in urban areas. The distribution of benefits and costs differs between these types. All three company types can be found at national level: of the 80 electricity distribution companies in Finland, the 15 largest supply electricity to $70 \%$ of the population. Two of the three largest suppliers have rural as well as urban customers. There are also companies that operate only at the scale of a rural municipality. (Finnish Energy 2017).

For companies in category 1 , costs are expected to be higher than benefits for the customers. In the case of those in category 2, customers in rural areas extract benefits from the urban customers and may become beneficiaries depending on the distribution of rural and urban customers. With companies in category 3 , the NPV is positive at the $95 \%$ significance level, and the customers benefit from the requirements of the Act.

In section 2, we introduced the concept of robust adaptation, described in terms of five criteria (Hallegatte et al. 2009). Of these, the Act only fulfils the criterion of no-regret measures, as it clearly creates benefits even in the absence of climate change. However, the Act is not easily retro-fitted; it does not increase safety margins at a low cost; it cannot be classified as a soft measure inasmuch as it results in major investment costs; and the time horizon of the measure is long. Finally, synergies with climate change mitigation efforts are unknown.

\section{Public Reaction}

The requirements in the 2013 Electricity Market Act led to major price increases in electricity transmission and an ensuing public outcry over the situation. This following account of these events is based on two sources: the official public releases of one of the distribution companies most seriously affected by the public reaction, and the press releases of the office of the Finnish Consumer Ombudsman. No media reports have been used. The situation can be understood from the press release of 4 February 2016 by the company most heavily affected by the public reaction: "Caruna regrets the distress caused to its customers after having to come to a solution on price increases, due to the large-scale requirement for improvement. The company has advised its customers regarding the network improvement measures required by the Electricity Market Act (Electricity Market Act 588/2013), as well as the price increases connected with them. The price increases have resulted in a large number of objections from citizens as well as in considerable media attention" (Caruna 4.2.2016). The situation began in early 2016, when major price increases were announced by the company, the largest distribution company in Finland. On 3 February 2016, the Consumer Ombudsman released a statement saying that it considered the price hikes excessive from consumers' point of view (KKV 3.2.2016). The Ombudsman further stated that the price increases were unreasonable because electricity is considered a necessity good, and with the company having a regional monopoly, consumers cannot change their supplier. Negotiations with the company started. The outcome, reached towards the end of 2016, is summed up in the following statement: "Caruna will reduce its fixed basic prices for electricity transmission by 25 per cent for all customers and both of its network companies for the next 12 months. This compensation will also balance the price increase in 2017. Furthermore, Caruna has given a commitment that it will not implement new price increases in 2017." The Competition and Consumer Authority even considered bringing a class action suit against Caruna (KKV 18.2.2016). This procedure has never been used in 
Finland despite an Act providing for it being on the books since 2007 (Class Action Act 13.4.2007/444).

On 25 August 2017, the 2013 Electricity Market Act was amended to incorporate regulation against price increases by transmission companies. In principle, a cap of $15 \%$ has been imposed on increases in transmission and distribution prices over a one-year period. (Amendment to the Elecricity Market Act 590/2017).

Notwithstanding, in 2018 Caruna and several other companies implemented another series of price increases, prompting the government to initiate an official investigation into the reasons for the price hikes (TEM 28.5.2018).

\section{Discussion}

The impacts of the 2013 Electricity Market Act were evaluated from many different angles (Partanen et al. 2006; Partanen et al. 2012; Government Proposal HE 20/2013) before the Act was passed and enacted, but no CBA such as that presented here was conducted. Before the Act came into force, Partanen et al. $(2006,2012)$ pointed out that a previously suggested $24-\mathrm{h}$ limit for rural blackouts would be economically inefficient and a 36-h limit would be economically more viable. Our analysis indicates that the 36-h limit for the rural network is still too restrictive in some cases, as the benefits for the rural population are not high enough to justify the costs brought by the increased price of electricity distribution. We must note, however, that according to the ministry tasked with drafting the Act, the legislation had goals apart from reducing the impacts of extreme weather. Principal among these were the need to address the maintenance backlog and to ensure the security of supply throughout the country. The suboptimality we have described here is to be understood in strictly economic terms. Indeed, we acknowledge that a policy may be informed by other than economic objectives, such as national security, as noted above.

In Europe, we have seen a significant increase in damages to forests that have partly been caused by forest management practices that have favoured plantation of tree species (Norway spruce) that are easily uprooted (Gregow et al. 2017). By better forest management practices, the damages could have been less severe although not avoidable (Suvanto et al. 2016; Pukkala et al. 2016), whereby compliance with the Act cannot be guaranteed by these measures alone. However, the duration of blackouts in rural areas could be reduced with appropriate forest management, and the costs of doing so would be substantially smaller than the costs of laying underground cables. The economic efficiency of such measures - or less strict requirements for rural areas - should have been compared to underground cabling. The present analysis has evaluated only the 24- and the 36-h limits from an economic perspective. An additional consideration is that if the renewal of the network had a less strict deadline, overhead power lines could be used until the end of their technical lifecycle, and then be replaced by the underground cables. This would substantially decrease the total costs resulting from the requirements of the Act.

One limitation of our analysis is that the benefits may rise if WTP for avoiding of blackouts increases in the future, for instance due to an increasing dependence of households on electricity. Increasing income levels could also have an effect. In 2015, disposable income had not increased in the past decade (Statistics Finland 2014b); however, since 2015 there has been a slight increase in mean, but not median, disposable income. Moreover, as the income elasticity of WTP is not reported in the original studies, scaling up the WTP figures would be 
questionable. In addition, many electronic appliances now come with a battery. As battery technology improves, WTP values may well decrease. On balance, we feel that the current WTP range is wide enough to cover the uncertainty in consumers' WTP and thus have not considered any increase or decrease in the WTP.

As mentioned in Section 3.1, CBA should account for distortionary effects, primarily those related to labour supply resulting from changes in household preferences between labour and leisure. A distortionary effect means that due to income taxation the labour supply is not at its optimal level in the equilibrium (Johansson-Stenman 2005). If a proposed project increases the labour supply, its distortionary effects are positive, and if it decreases the supply, the effects are negative. There is little empirical evidence on the effect of changing energy prices on the labour supply; only the effects of demand have been studied rigorously (e.g. Asafu-Adjaye 2000; Papapetrou 2001). In our analysis, potential labour supply effects are more important, as the costs are mainly borne by household users; it is difficult to say anything certain about these or even about the direction of a possible change.

Distributional effects can be studied by comparing the benefits received by different income groups and assigning different social welfare weights to different groups, so that lower income groups are assigned a higher weight (e.g. Adler 2013), or by reporting the distributional issues qualitatively in the analysis (Nyborg 2014). In this analysis, it is possible to divide the individuals into urban and rural populations, as the benefits are distributed unevenly among the two groups. However, we cannot use individual benefitincome pairs as a basis for calculating distributional weights, and thus only report distributional effects qualitatively.

An analysis by the Bank of Finland (Mäki-Fränti 2016) has indicated that the income differences between regions in Finland are small. The five least urbanised regions have an average income $77 \%$ of those with the highest urbanisation rate (Mäki-Fränti 2016). In the analysis, we have used average VoLL figures for households for all different regions. Averages could be adjusted regionally to take into account the effect of income on VoLL. None of the primary literature studies report the income elasticity of VoLL, but Carlsson et al. (2011) report a positive income effect for the reported VoLL values. This would mean an even lower NPV for the rural case, but an improved NPV for the urban case. The differences in the production per capita in the rural and urban regions are much higher, but taxes and transfers decrease the income gap between urban and rural population. However, if distributional concerns are taken into account, both the benefits and the costs of the rural population should be assigned slightly higher weights than those of the urban population, making the rural case more negative.

Of greatest concern are those rural areas that have their own distribution company. In such cases, the rural population needs to pay a higher price for the increase in the electricity price as compared to its WTP. Even if less urbanised regions are not that poor on average, the poorest municipalities are located in the rural areas. Moreover, the share of low-income households is much higher in rural areas than in urban areas, around $4 \%$ compared to around $2 \%$. (Statistics Finland 2018). Electricity companies operating solely in rural areas may find it difficult to fully recoup their investment. They companies may consider not investing in underground cabling, but rather in improving their forest management practices around power lines. However, there is no guarantee that such measures will increase the reliability of the network to the standard required by the Act. The independence of such companies may be jeopardised, possibly resulting in mergers.

The literature (Onuma et al. 2016; Onuma et al. 2017a, 2017b) shows that CCA and DRR are often dynamic processes, as both individuals and societies learn from past disasters and 
increase their preparedness. In our case, the high impact storms in 2006, 2010 and 2011 clearly had an impact on public policy, and these experiences were part of the knowledge base informing the regulation. Our analysis shows that this dynamic process can also lead to an overreaction from the point of view of economic optimality.

\section{Conclusions and Implications}

Over-adaptation to the impacts of extreme weather and climate change has rarely been discussed in the literature. The literature is rich in examples where CCA and DRR measures are reported to be economically efficient, whereas counter-examples are few. We claim that this is due partly to reporting practices, and partly to imprecise definitions of efficient adaptation.

As a case study, we undertook a CBA of the 2013 Finnish Electricity Market Act, which imposes strict requirements on electricity distribution companies to prevent blackouts in their grid. Our results indicate that in urban areas the public policy and the required investment are economically efficient. However, in rural areas, the costs of the required investments exceed their economic benefits, indicating that the optimal requirements would have been somewhere between the old practices and the new. Depending on the operating area of a given electricity distribution company, the present requirements will result either in urban customers paying for the improved well-being of rural customers or rural customers having to bear the high cost of improving network reliability on their own. This cost is expected to be higher than the NPV for the improvement. Our results indicate that the present policy may be an overreaction to an existing problem: it seems that at some "quantity" (urban requirements), NPV is strictly positive, whereas at another level of service provision (rural requirements), NPV is negative.

Our case study indicates that over-adaptation is a relevant concept meriting consideration the CCA and DRR literature. Our case also shows that when assessing the success of public regulation and measures aiming at reducing the risk of extreme weather events and climate change, public opinion and potential and perceived negative effects on the public should be considered. The population affected by the impacts may not accept the implementation of otherwise effective DRR and CCA measures. This applies particularly when there is a potential mismatch between societal and individual preferences. Furthermore, the WTP of the people affected should be carefully evaluated prior to any policy change, as the WTP obtained in surveys may prove to be different from the WTP of the affected population. All in all, from the point of view of good governance, the significance of identifying over-adaptation is that it adds to our understanding of strong popular inclinations to avoid risks relating to the availability of an essential good, such as energy. Popular concerns may affect decision-making such that the resulting actions clash with the equally important objective of providing that good being at an affordable price.

Reducing the impacts of extreme weather events and adapting to climate change are challenging tasks given the many climatic, societal and political uncertainties. Despite these uncertainties, designing and implementing policy instruments and concrete measures is highly important due to the intensifying threat of climate change. Economic efficiency of the envisaged measures is one key criterion to be used in designing the instruments; however, the challenge for policy makers is to design instruments that are accepted by the public. 
System flexibility is essential in ensuring that the net benefits of a given project do not fall in the range of over-adaptation. This study has shown that CBAs evaluating potential CCA and DRR measures should better address suboptimalities.

\section{Appendix}

Milestones and events
A government report by an investigator"
Improving the reliability of electricity
network"
A government report" The compensation
costs for blackouts"
A working group named "“'Preventing
disruptions in the electricity network
and improvement of the operational
goals" report: "Improving the reliability
of the supply of electricity"

A report by Technical University of Lappeenranta “

A legislative proposal by the Ministry of Economic Affairs and Employment of Finland (TEM) "Measures to improve the reliability of electricity supply and decrease the impacts of blackouts"

An impact analysis report of the legislative proposal of TEM, by Technical University of Lappeenranta "An impact analysis of the measures to improve the reliability of electricity supply and decrease the impacts of blackouts"
Time and reference Notes

2002 / KTM 18/2002 Early report including a discussion on the urban requirement of a maximum 6-h blackout.

2002 / KTM 11/2002 Early report including discussion on the compensation that customers are entitled in case of blackouts.

KTM 19.12.2006 The report included discussion on the blackouts statistics; historical development of blackouts; international comparison; discussion on the maximum allowed blackout periods; discussion and very crude estimates on the costs and benefits of increasing the underground cabling rates of lowand medium-voltage networks

Partanen et al. (2006) The report included a discussion as well as calculations of the benefits and costs of different maximum allowable blackout durations (6-10 h total blackout duration in one year under normal conditions, 24-48 h during major disturbances); It was concluded that the maximum of $6-10 \mathrm{~h}$ cumulative duration per customer is reasonable in normal conditions, but setting a strict time limit in case of major disturbances - such as storms - cannot be justified from an economic perspective; The report also mentions that for some (rural) electricity companies, there could be less strict deadlines.

TEM 16.3.2012 Included the final (acceptability) requirements of at maximum 6-h blackouts in urban areas, and either a 24- or a 36-h maximum duration in rural areas

Partanen et al. (2012) In this report is was concluded that the 24-h deadline for the maximum blackout periods in rural areas is too strict, and the $36 \mathrm{~h}$ deadline is more favourable from an economic point of view. Longer maximum blackout periods were not considered, as the proposal did not include them.

A proposal for the new Electricity Market Act. 
Open Access This article is distributed under the terms of the Creative Commons Attribution 4.0 International License (http://creativecommons.org/licenses/by/4.0/), which permits unrestricted use, distribution, and reproduction in any medium, provided you give appropriate credit to the original author(s) and the source, provide a link to the Creative Commons license, and indicate if changes were made.

Publisher's Note Springer Nature remains neutral with regard to jurisdictional claims in published maps and institutional affiliations.

\section{References}

Accent Marketing and Research. (2004). Consumer expectations of DNOs and WTP for improvements in service, London

Accent Marketing and Research. (2008). Expectations of DNOs and willingness to pay for improvements. A report to Ofgem

Adler M. (2013). Cost-benefit analysis and distributional weights: an overview. Working paper EE 13-04. Duke Law School

Adler MD (2016) Benefit-cost analysis and distributional weights: an overview. Rev Environ Econ Policy 10: 264-285

Äijälä M, Kemppinen O, Kauppila A. (2014). Kohtuullisen tuottoasteen määrittäminen sähkö- ja maakaasuverkkotoimintaan sitoutuneelle pääomalle. Loppuraportti Energiavirastolle https://www. energiavirasto.fi/documents/10179/0/EY_kohtuullinen_tuotto_WACC_loppuraportti.pdf/65533364-df154c0c-96ae-ad3d8a4268eb. Accessed 17 Jan 2019

Amendment to the Elecricity Market Act (Laki sähkömarkkinalain muuttamisesta) (590/2017) Annettu Helsingissä 25 päivänä elokuuta 2017. https://www.finlex.fi/fi/laki/alkup/2017/20170590 (in Finnish). Accessed 17 Jan 2019

Asafu-Adjaye J (2000) The relationship between energy consumption, energy prices and economic growth: time series evidence from Asian developing countries. Energy Econ 22:615-625. https://doi.org/10.1016/S0140 9883(00)00050-5

Atkinson C, Mourate S, Szymanski S, Ozdemiroglu E (2008) Are we willing to pay enough to 'back the bid?: valuing the intangible impacts of London's bid to host the 2012 summer Olympic games. Urban Stud 45(2): 419-444

Barnett J, O’Neill S. (2010). Maladaptation

Bell CM, Urbach DR, Ray JG, Bayoumi A, Rosen AB, Greenberg D, Neumann PJ (2006) Bias in published cost effectiveness studies: systematic review. Bmj 332(7543):699-703

Bloomberg (2016). Bloomberg guide WACC. Available: http://businesslibrary.uflib.ufl.edu/c.php?g=114612 $\& p=746562$. Accessed 17 Jan 2019

Boadway R (2006) Principles of cost-benefit analysis. Public Policy Review 2(1):1-44

Boardman AE, Greenberg DH, Vining AR, Weimer DL (2006) Cost-benefit analysis: concepts and practice, vol 3. Prentice Hall, Upper Saddle River

Bonzanigo L., Kalra N. (2014). Making informed investment decisions in an uncertain world: a short demonstration. World Bank policy Research working paper 6765. https://doi.org/10.1596/1813-9450-6765

Bos F, van der Pol T., Romijn G. (2018). Should CBA's include a correction for the marginal excess burden of taxation?

Carlsson F, and Martinsson P. (2008). Does it matter when a power outage occurs? - A choice experiment study on the willingness to pay to avoid power outages. Energy Econ 30:1232-1245

Carlsson F, Martinsson P, Akay A (2011) The effect of power outages and cheap talk on willingness to pay to reduce outages. Energy Econ 33(5):790-798

Caruna (4.2.2016) https://www.caruna.fi/en/news/caruna-regrets-distress-caused-its-customers-and-respondsenergy-authority-report-electricity. Accessed 19 Mar 2018

Caruna (31.10.2017) https://www.caruna.fi/ajankohtaista/sahkoverkon-maakaapelointi-vapauttaa-vuositasollayli-1-000-hehtaaria-maata. Accessed 10 Nov 2017

Class Action Act (Ryhmäkannelaki) (13.4.2007/444) https://www.finlex.fi/fi/laki/ajantasa/2007/20070444 (in Finnish). Accessed 17 Jan 2019

COM (European Commission) (2013) Communication from the Commission to the European Parliament, the Council, the European Economic and Social Committee and the Committee of the Regions - An EU Strategy on adaptation to climate change. $\operatorname{COM}(2013) 216$ final 
Dessai S, Hulme M (2007) Assessing the robustness of adaptation decisions to climate change uncertainties: a case study on water resources management in the east of England. Glob Environ Chang 17(1):59-72

Easterbrook PJ, Gopalan R, Berlin JA, Matthews DR (1991) Publication bias in clinical research. Lancet 337(8746):867-872

ECB (European Central Bank) (2018) Statistical Data Warehouse. Euribor 1-year - Historical close, average of observations through period. http://sdw.ecb.europa.eu/quickview.do?SERIES_KEY=143.FM.M.U2.EUR. RT.MM.EURIBOR1YD .HSTA. Accessed 17 Jan 2019

EEA (2009) EC4MACS project websites. Conclusions at http://www.ec4 macs. eu/downloads/reports/InterimAssessment/EC4MACS-InterimAssessment-chap5.pdf. Accessed 17 Jan 2019

Eisenack K (2014) The inefficiency of private adaptation to pollution in the presence of endogenous market structure. Environ Resour Econ 57:81-99. https://doi.org/10.1007/s10640-013-9667-6

Electricity Market Act (2013) 9.8.2013/588 / https://www.finlex.fi/fi/laki/ajantasa/2013/20130588 (In Finnish). Accessed 17 Jan 2019

ENEASE (2016) Private communication with the consultancy in charge of gathering data about the blackouts in Finland

Energy Authority (2011) Sähkönjakeluverkon verkkokomponentit ja yksikköhinnat vuodelle 2011. Statistics available: https://www.energiavirasto.fi/sahkonjakeluverkon-komponenttien-yksikkohinnat-vuodelle-2011 (In Finnish). Accessed 17 Jan 2019

Energy Authority (2014) Sähkönjakeluverkon verkkokomponentit ja yksikköhinnat vuodelle 2014. Statistics available: https://www.energiavirasto.fi/sahkonjakeluverkon-komponenttien-yksikkohinnat-20141. Accessed 17 Jan 2019

Energy Authority (2015) Sähköverkkotoiminnan teknisiä tunnuslukuja. Available: https://www.energiavirasto. fi/tunnusluvut2014 (In Finnish). Accessed 17 Jan 2019

Energy Authority (2016) Sähkönjakeluverkon verkkokomponentit ja yksikköhinnat 2016-2023. Statistics available: https://www.energiavirasto.fi/verkkokomponentit-ja-yksikkohinnat-2016-2023 (In Finnish). Accessed 17 Jan 2019

Ernst, Young (2014) A document prepared for Energy Authority to set the reasonable return on investment. https://www.energiavirasto.fi/documents/10179/0/EY_kohtuullinen_tuotto_WACC_loppuraportti. pdf/65533364-df15-4c0c-96ae-ad3d8a4268eb (In Finnish). Accessed 17 Jan 2019

Finnish Energy (Energiateollisuus) (2014) Sähkön keskeytystilasto 2014 (Electricity blackout statistics 2014 - in Finnish). Available: https://energia.fi/ajankohtaista_ja_materiaalipankki/tilastot/sahkotilastot/keskeytystilasto. Accessed 17 Jan 2019

Finnish Energy (Energiateollisuus) (2017) Sähköverkkoyhtiöt (Electricity grid companies) (in Finnish). Available: https://energia.fi/perustietoa_energia-alasta/energiaverkot/sahkoverkot/sahkoverkkoyhtiot. Accessed 11 Jun 2018

Florio M (2014) Applied welfare economics: cost-benefit analysis of projects and policies, 22. Routledge

Freeman M, Herriges J, Kling C (2014) The measurement of environmental and resource values. RFF Press, London

Government Proposal HE 20/2013 (in Finnish): Hallituksen esitys eduskunnalle sähkö- ja maakaasumarkkinoita koskevaksi lainsäädännöksi. HE 20/2013. http://plus.edilex.fi/tukes/fi/he/20130020. Accessed 17 Jan 2019

Gregow H, Peltola H, Laapas M, Saku S, Venäläinen A (2011) Combined occurrence of wind, snow loading and soil frost with implications for risks to forestry in Finland under the current and changing climatic conditions. Silva Fennica 45(1):35-54

Gregow H, Muzaffer EA and Laaksonen A (2017) Increasing large scale windstorm damage in Western, central and northern European forests, 1951-2010. Scientific Reports. (http://rdcu.be/q66j)

Groenemeijer P, Vajda A, Lehtonen I, Kämäräinen M, Venäläinen A, Gregow H, Becker N, Nissen K, Ulbrich U, Berlin F, Nápoles OM, Paprotny D (2016). Present and future probability of meteorological and hydrological hazards in Europe, Deliverable 2.5 of RAIN - Risk Analysis of Infrastructure Networks in Response to Extreme Weather. http://rain-project.eu/wp-content/uploads/2016/09/D2.5_REPORT_final.pdf. Accessed 17 Jan 2019

Hallegatte S (2009) Strategies to adapt to an uncertain climate change. Global Environmental Change 19:240 247. https://doi.org/10.1016/j.gloenvcha.2008.12.003

Hallegatte S, Shah A, Lempert R, Brown C, Gill S (2012) Investment decision making under deep uncertaintyapplication to climate change. World Bank Policy Research Working Papers. https://doi.org/10.1596/18139450-6193

Hallegatte S, Vogt-Schilb A, Bangalore, M, Rozenberg J (2016). Unbreakable: building the resilience of the poor in the face of natural disasters. Climate change and development series. Washington, DC: World Bank. https://doi.org/10.1596/978-1-4648-1003-9. License: creative commons attribution CC BY 3.0 IGO

Hanemann WM (2000) Adaptation and its measurement: an editorial comment. Clim Chang 45:571-581 
Holland P (2008) An economic analysis of flood warning in Navua, Fiji. European Union Development Fund (EU EDF) 8 - SOPAC Project Report 122, Reducing Vulnerability of Pacific ACP States, Fiji Technical Report. SOPAC (Pacific Islands Applied Geosciences Commission), Suva, Fiji

Honkapuro S (2006). DEA-mallilla suoritettavan tehokkuusmittauksen kehittäminen. Tilaustutkimusraportti, Lappeenranta 2006

IPCC (2012). Managing the risks of extreme events and disasters to advance climate change adaptation: a special report of working groups I and II of the intergovernmental panel on climate change. Cambridge U

IPCC (2014) Annex II: Glossary [Agard, J., E.L.F. Schipper, J. Birkmann, M. Campos, C. Dubeux, Y. Nojiri, L. Olsson, B. Osman-Elasha, M. Pelling, M.J. Prather, M.G. Rivera-Ferre, O.C. Ruppel, A. Sallenger, K.R. Smith, A.L. St Clair, K.J. Mach, M.D. Mastrandrea, and T.E. Bilir (eds.)] Climate Change 2014: Impacts, adaptation, and vulnerability. Part B: Regional Aspects. Contribution of Working Group II to the Fifth Assessment Report of the Intergovernmental Panel on Climate Change

Johansson-Stenman O (2005) Distributional weights in cost-benefit analysis - should we forget about them? Land Econ 81:337-352

Kahneman D, Knetsch JL, Thaler RH (1991) The endowment effect, loss aversion, and status quo Bias. J Econ Perspect 5(1):193-206

Karvonen O (2018). Personal communication by e-mail and phone. [05.11.2018]. Osmo Karvonen, CEO, Nurmijärven Sähkö

KKV (Finnish Competition and Consumer Authority) (3.2.2016) https:/www.kkv.fi/en/current-issues/pressreleases/2016/3.2.2016-consumer-ombudsman-to-engage-caruna-in-negotiations-concerning-increases-toelectricity-transmission-prices/. Accessed 17 Jan 2019

KKV (Finnish Competition and Consumer Authority) (18.2.2016) https:/www.kkv.fi/en/current-issues/pressreleases/2016/18.2.2016-caruna-and-the-consumer-ombudsman-reach-a-negotiated-solution\%2D\%2 Dcaruna-will-phase-in-price-increases-over-a-longer-period-of-time/. Accessed 17 Jan 2019

Konrad KA, Thum M (2014) The role of economic policy in climate change adaptation. CESifo Economic Studies 60:32-61. https://doi.org/10.1093/cesifo/ift003

KTM (11/2002) Sähkökatkosten vakiokorvaukset, Kauppa- ja teollisuusministeriön työryhmä- ja toimikuntaraportteja 11/2002 (In Finnish)

KTM (18/2002) Sähkön toimitusvarmuuden parantaminen, Selvitysmiehen raportti, Kauppa- ja teollisuusministeriön tutkimuksia ja raportteja 18/2002. (In Finnish)

KTM (19.12.2006) Sähkönjakelun toimitusvarmuuden kehittäminen. Sähkön jakeluhäiriöiden ehkäisemistä ja jakelun toiminnallisia tavoitteita selvittäneen työryhmän raportti. (In Finnish)

LaCommare K, Joseph E (2004). Understanding the cost of power interruptions to U.S. Electricity Customers. pdf saatavilla: https://escholarship.org/uc/item/1fv4c2fv\#page-3. Accessed 17 Jan 2019

Lempert RJ (2014) Embedding (some) benefit-cost concepts into decision support processes with deep uncertainty. Journal of Benefit-Cost Analysis 5:487-514

Lempert, Groves (2010) Identifying and evaluating robust adaptive policy responses to climate change for water management agencies in the American west. Technological Forecasting \& Social Change 77:960-974

Lempert R, Kalra N, Peyraud S, Mao Z, Tan SB, Cira D, Lotsch A (2013). Ensuring robust flood risk management in Ho Chi Minh City. World Bank Policy Research Working Paper

London Economics (2013). The value of lost Load (Voll) for electricity in Great Britain. Final report for OFGEM and DECC

Mäki-Fränti P (2016). Alueelliset tuloerot Suomessa 2016 (in Finnish: regional income differences in Finland in 2016). https://www.eurojatalous.fi/fi/2016/artikkelit/alueelliset-tuloerot-suomessa-2016/. Accessed 17 Jan 2019

Mäkinen A, Bastman J, Järventausta P, Verho P, Repo S (2009). Sähkönsiirtoverkon häiriökeskeytysten aiheuttaman haitan arvioinnissa käytettävien parametrien päivittäminen, Tampereen Teknillinen YliopistoKuismin L. 2010. Ilmastonmuutoksen vaikutukset viemäröintiin ja jätevesien käsittelyyn. DI-työ. Aalto-yliopisto, Espoo. (In Finnish)

Matschoss K (2014). Laatukannustimen kehitys: raportti kuluttajakyselystä Helsinki: Kuluttajatutkimuskeskus. 68 Sivumäärä (Tutkimuksia ja selvityksiä / Kuluttajatutkimuskeskus; nro 9/2014) (In Finnish only)

Mendelsohn R (2012) The economics of adaptation to climate change in developing countries. Climate Change Economics 3:1-21

Møller AP, Jennions MD (2001) Testing and adjusting for publication bias. Trends Ecol Evol 16(10):580-586

Nakicenovic N et al. (2000). Special report on emissions scenarios (SRES): a special report of working group III of the intergovernmental panel on climate change. IPCC and Cambridge University Press. http://pure.iiasa. ac.at/id/eprint/6101/. Accessed 17 Jan 2019

Noble IR, Huq S, Anokhin YA, Carmin J, Goudou D, Lansigan FP, Osman-Elasha B, and Villamizar A (2014) Adaptation needs and options. In: Climate Change 2014: Impacts, Adaptation, and Vulnerability. Part A: Global and Sectoral Aspects. Contribution of Working Group II to the Fifth Assessment Report of the 
Intergovernmental Panel on Climate Change [Field, C.B., V.R. Barros, D.J. Dokken, K.J. Mach, M.D. Mastrandrea, T.E. Bilir, M. Chatterjee, K.L. Ebi, Y.O. Estrada, R.C. Genova, B. Girma, E.S. Kissel, A.N. Levy, S. MacCracken, P.R. Mastrandrea, and L.L. White (eds.)]. Cambridge University Press, Cambridge, United Kingdom and New York, NY, USA, pp. 833-868

Nordman E, Isely E, Isely P, Denning R (2018) Benefit-cost analysis of stormwater green infrastructure practices for Grand Rapids, Michigan, USA. J Clean Prod 200:501-510

Nurmi V, Ahtiainen H (2018) Distributional weights in environmental valuation and cost-benefit analysis: theory and practice. Ecol Econ 150:217-228

Nurmi V, Votsis A, Perrels A, Lehvävirta S (2016) Green roof cost-benefit analysis: special emphasis on scenic benefits. J Benefit-Cost Anal 7:488-522

Nyborg K (2014). Project evaluation with democratic decision-making: what does cost-benefit analysis really measure?, memorandum, Department of Economics, University of Oslo, no. 08/2014, dep. Of economics, Univ. of Oslo, Oslo. https:/www.econstor.eu/bitstream/10419/102065/1/781242428.pdf. Accessed 17 Jan 2019

OECD (2018). Cost-benefit analysis and the environment: further developments and policy use. Organisation for economic co-operation and development (OECD), Paris

Onuma H, Shin KJ, Managi S (2017a) Reduction of future disaster damages by learning from disaster experiences. Nat Hazards 87(3):1435-1452

Onuma H, Shin LJ, Managi S (2017b) Household preparedness for natural disasters - impact of disaster experience and implication for future disaster risks in Japan. International Journal of Disaster Risk Reduction 21:148-158

Palisade @Risk for Risk Analysis (2018) http:/www.palisade.com/risk/default.asp. Accessed 17 Jan 2019

Papapetrou E (2001) Oil price shocks, stock market, economic activity and employment in Greece. Energy Econ 23:511-532. https://doi.org/10.1016/S0140-9883(01)00078-0

Partanen J (2015). Sähkönjakeluverkon komponenttien pitoaikojen rooli taloudellisessa valvonnassa. Nestra Oy. Found in: https://www.energiavirasto.fi/documents/10179/0/Caruna+Oy+ja+Caruna+Espoo+Oy+-+liite. pdf/ecf145dd-9a1e-4259-9a30-901bef520ea3. Accessed 17 Jan 2019

Partanen J, Lassila J, Kaipia T, Matikainen M, Järventausta P, Verho P, Mäkinen A, Kivikko K, Pylvänäinen J, Nurmi V-P (2006). Sähkönjakeluverkkoon soveltuvat toimitusvarmuuskriteerit ja niiden raja-arvot sekä sähkönjakelun toimitusvarmuudelle asetettavien toiminnallisten tavoitteiden kustannusvaikutukset. Tilaustutkimusraportti. Lappeenrannan teknillinen yliopisto \& Tampereen teknillinen yliopisto. (in Finnish)

Partanen J, Lassila J, Kaipia T, Haakana J (2012). Sähkönjakelun toimitusvarmuuden parantamiseen sekä sähkökatkojen vaikutusten lieventämiseen tähtäävien toimenpiteiden vaikutusten arviointi. Lappeenrannan teknillinen yliopisto 2012. (in Finnish)

Perrels A, Harjanne A, Nurmi V, Pilli-Sihvola K, Heyndricx Ch, Stahel A (2013) The contribution of weather and climate service innovations in adaptation to climate change and its assessment, deliverable 2.2, FP7 ToPDAd project, http://www.topdad.eu/publications. Accessed 17 Jan 2019

Pilli-Sihvola K, Väätäinen-Chimpuku S (2016). Defining climate change adaptation and disaster risk reduction policy Integration: Evidence and Recommendations from Zambia. International Journal of Disaster Risk Reduction. https://doi.org/10.1016/j.ijdrr.2016.07.010

Pilli-Sihvola K, Harjanne A, Haavisto R (2017) Adaptation by the least vulnerable: managing climate and disaster risks in Finland. International Journal of Disaster Risk Reduction. https://doi.org/10.1016/j. ijdrr.2017.12.004

Pukkala T, Laiho O, Lähde E (2016) Continuous cover management reduces wind damage. For Ecol Manag 372: 120-127. https://doi.org/10.1016/j.foreco.2016.04.014

Quentin Grafton R (2010) Adaptation to climate change in marine capture fisheries. Mar Policy 34(3):606-615. https://doi.org/10.1016/j.marpol.2009.11.011

Rivera C, Tehler H, Wamsler C (2015) Fragmentation in disaster risk management systems: A barrier for integrated planning. International Journal of Disaster Risk Reduction 14:445-456. https://doi.org/10.1016/j. ijdrr.2015.09.009

Rogelj J, Meinshausen M, Knutti R (2012) Global warming under old and new scenarios using IPCC climate sensitivity range estimates. Nat Clim Chang 2:248-253. https://doi.org/10.1038/nclimate1385

Saastamoinen A, Kuosmanen T (2016) Quality frontier of electricity distribution: supply security, best practices, and underground cabling in Finland. Energy Econ 53:281-292

Schwab B, Lusztig P (1969) A comparative analysis of the net present value and the benefit-cost ratio as measures of the economic desirability of investments. J Financ 24(3):507-516

Shreve CM, Kelman I (2014) Does mitigation save? Reviewing cost-benefit analyses of disaster risk reduction. International Journal of Disaster Risk Reduction 10:213-235. https://doi.org/10.1016/j.ijdrr.2014.08.004 
Silvast A, Heine P, Lehtonen M, Kivikko K, Mäkinen A, Järventausta P. (2005). Sähkönjakelun keskeytyksestä aiheutuva haitta. Tampereen teknillinen Yliopisto

Smith N, Brown C, McDonald G, Ayers M, Kipp R, Saunders W (2017) Challenges and opportunities for economic evaluation of disaster risk decisions. Economics of Disasters and Climate Change 1:111-120. https://doi.org/10.1007/s41885-017-0007-0

Statistics Finland (Tilastokeskus) (2014a) Tilastokeskus, Sähkön käyttö toimialoittain. https://www.stat. fi/til/tene/tau.html (in Finnish). Accessed 17 Jan 2019

Statistics Finland (Tilastokeskus) (2014b) Suomen virallinen tilasto (SVT): Tulonjakotilasto [verkkojulkaisu]. ISSN=1795-8121. pienituloisuus 2015, 2 Käytettävissä oleva rahatulo keskimäärin 37900 euroa . Helsinki: Tilastokeskus [viitattu: 11.6.2018]. (in Finnish) Saantitapa: http://www.stat.fi/til/tjt/2015/02/tjt_2015_02_201703-24_kat_002 fi.html. Accessed 17 Jan 2019

Statistics Finland (Tilastokeskus) (2016) Väestörakenne (Population structure). Available: http://www.stat. fi/til/vaerak/index.html (In Finnish). Accessed 17 Jan 2019

Statistics Finland (Tilastokeskus) (2017) Sähkön hinta kuluttajatyypeittäin, Energian hinnat. Tilasto saatavilla: http://www.stat.fi/til/yrti/ (In Finnish). Accessed 17 Jan 2019

Statistics Finland (Tilastokeskus) (2018) Suomen virallinen tilasto (SVT): Tulonjakotilasto [web article]. ISSN=1795-8121. Helsinki: Tilastokeskus [viitattu: 11.6.2018]. (in Finnish) Saantitapa: http://www.stat. fi/til/tjt/. Accessed 17 Jan 2019

Suvanto S, Henttonen HM, Nöjd P, Mäkinen H (2016) Forest susceptibility to storm damage is affected by similar factors regardless of storm type: comparison of thunder storms and autumn extra-tropical cyclones in Finland. For Ecol Manag 381:17-28. https://doi.org/10.1016/j.foreco.2016.09.005

Tahvonen O, Pihlainen S, Niinimäki S (2013) On the economics of optimal timber production in boreal scots pine stands. Can J For Res 43(8):719-730

TEM (Ministry of Economic Affairs and Employment of Finland) (16.3.2012) Työ- ja elinkeinoministeriön ehdotus toimenpiteistä sähkönjakelun varmuuden parantamiseksi sekä sähkökatkojen vaikutusten lievittämiseksi. (In Finnish)

TEM (Ministry of Economic Affairs and Employment of Finland) (28.5.2018) Professori Jarmo Partanen selvittämään sähkön jakeluverkkojen hinnankorotuksia ja niiden alueellista kohdentumista. http://tem. fi/artikkeli/-/asset_publisher/professori-jarmo-partanen-selvittamaan-sahkon-jakeluverkkojenhinnankorotuksia-ja-niiden-alueellista-kohdentumista. Accessed 17 Jan 2019

Tol RS (2005) Adaptation and mitigation: trade-offs in substance and methods. Environ Sci Pol 8:572-578

UN (United Nations), Department of Economic and Social Affairs, Population Division. (2014) World urbanization prospects: the 2014 revision, CD-ROM Edition

Watkiss P, Hunt A, Blyth W, Dyszynski J (2014) The use of new economic decision support tools for adaptation assessment: a review of methods and applications, towards guidance on applicability. Clim Chang 132:401416. https://doi.org/10.1007/s10584-014-1250-9

Weitzman ML (2001) Gamma discounting. Am Econ Rev 91(1):260-271 
Reprinted under the Creative Commons Attribution License 



\title{
Innovations in weather services as a crucial building block for climate change adaptation in road transport
}

\author{
Karoliina Pilli-Sihvola ${ }^{1}$, Väinö Nurmi ${ }^{2}$, Adriaan Perrels ${ }^{3}$, Atte Harjanne ${ }^{4}$ \\ Finnish Meteorological Institute, Helsinki, Finland.
}

\author{
Patrick Bösch ${ }^{5}$, Francesco Ciari ${ }^{6}$ \\ Swiss Federal Institute of Technology - ETH, Zurich, Switzerland
}

\begin{abstract}
The road transport sector is facing rising uncertainties in planning and operations due to climate change induced changes in weather variability and extreme events. However, because of the high level of uncertainty related to the future climate, adaptation measures should be robust so as to retain the option value of the portfolio of measures. As an example of such a measure, this paper evaluates how foreseen innovations in weather services could reduce weather sensitivity and, consequently reduce the negative effects of climate change in the sector. The study is based on a theoretical framework on climate change adaptation and valuation of weather and climate services using the Weather Service Chain Analysis. We apply these frameworks to the road transport sector with a special emphasis on drivers' decision making before and during a trip. We show that improved weather information, including more accurate weather forecasts, new applications and information dissemination channels can decrease the vulnerability of the mode to projected shifts in extreme weather patterns due to climate change.
\end{abstract}

Keywords: Adaptation, Climate Change, Information, Innovation, Road transport, Weather Service

\section{Introduction}

\subsection{Climate change and the transport sector}

The link between the transport sector and climate change is twofold. Mitigation of climate change, for instance the reduction of greenhouse gas emissions from transport activities, has received plenty of attention due to its significant contribution to the global emissions (IPCC, 2014a). However, the transport sector is not only a contributor to climate change, but in all likelihood will be notably affected by its consequences (Hallegatte, 2009; IPCC, 2014b; Love et al., 2010).

The report by the Intergovernmental Panel on Climate Change entitled Impacts, Adaptation and Vulnerability reviews the expected direct and indirect impacts of climate change on transport (IPCC, 2014b). The impacts are not uniform, and depend, for instance, on the geographic area considered, transport mode, time frame and factors such as technological development and economic growth (IPCC, 2014b; Koetse and Rietveld, 2009; Michaelides et al., 2014; Nokkala et al.,

\footnotetext{
1 P.O. BOX 503, FI-00101 Helsinki T: +358 503094660 F: +358 295393146 E: Karoliina.pilli-sihvola@fmi.fi

2 P.O. BOX 503, FI-00101 Helsinki T +358 504071436 F: +358 295393146 E: vaino.nurmi@fmi.fi

${ }^{3}$ P.O. BOX 503, FI-00101 Helsinki T: +358 505838575 F: +358 295393146 E: adriaan.perrels@fmi.fi

4 P.O. BOX 503, FI-00101 Helsinki T: +358 50373 1841F: +358 295393146 E: atte.harjanne@fmi.fi

5 Stefano Franscini Platz, 5, Zurich T: +41 446333952 F: +41 446331057

E: patrick.boesch@ivt.baug.ethz.ch

${ }^{6}$ Stefano Franscini Platz, 5, Zurich T: +41 446337165 F: +41 446331057

E: ciari@ivt.baug.ethz.ch
} 
2012; MMM, 2012). Koetse and Rietveld (2009) suggest that the changing weather variability and extreme weather events may be the impacts of most concern for the transport sector.

Weather related disturbances, existing in the current climate, already affect the transport sector. In the aviation sector, the main weather related costs are related to both primary and network delays, cancellations and diversion (e.g. Cook et al., 2004). For road transport, weather related accident costs dominate other weather related costs (Nokkala et al., 2012). With regards to rail transport, extreme weather has an effect on operating efficiency, physical infrastructure and the safe passage of freight and people (Rossetti, 2007). For maritime transport, weather has an effect on stability, journey time, safety of the cargo and vessel, fuel efficiency and admissible load factor (Nurmi et al., 2012). Additionally, transport modes do not operate in isolation but rather constitute a multi-modal transport network, in which chain events can emerge even if adverse weather directly affects only one mode. Indirect impacts of climate change may stem from for instance changes in agricultural, tourism and production patterns (Koetse and Rietveld, 2009).

The projected effects of climate change on the frequency and intensity of extreme weather events in different regions in Europe still have a significant degree of uncertainty due to their combination with other sources of uncertainty, such as natural variability of the climate, uncertainty in climate and economic modelling and socioeconomic development. The highest level of uncertainty is related to changes in extremes. Nonetheless, with reasonable confidence it is projected that the frequency and intensity of cold waves is will decrease throughout Europe, while the duration and occurrence of heat waves is projected to increase. In particular the projected levels of extreme precipitation and wind speeds in future climates entail higher uncertainty as compared to temperature. Jylhä et al. (2009), nonetheless, find that in northern Europe, extreme downpours may be expected to increase. In principle, extreme winter-weather events (cold spells, blizzards and snowfall) are expected to decrease in most regions of Europe by 2050; an exception is that the frequency of extreme snow storms is projected to slightly increase in Northern Europe. (Vajda et al., 2011; Perkins et al., 2012). In a study on the Alpine region, Rajzak et al. (2013) project that in several areas of the northern Alpine region, the severity of extreme precipitation (snow) in winter time increases, while the frequency might decrease. In other seasons, the tendency is towards reduced frequency and increased intensity in most Alpine regions.

\subsection{Climate change adaptation in the transport sector}

For the transport sector adaptation to projected changes in extreme weather patterns (Koetse and Rietveld, 2009), while keeping in mind the high uncertainty in climate projections (Vajda et al., 2011), costly adjustment of transport infrastructure is not necessarily the most optimal option (Hallegatte, 2009). In turn, this implies that scenario-based long-term climate information is rarely the key driver behind climate change adaptation (CCA) decisions (Love et al., 2010). Instead, the focus should be on finding strategies and adaptation measres which take into account the changing climate, whilst also addressing the inherent uncertainty related to climate change. To address this issue, robust CCA decisions and strategies, which are insensitive to the uncertainty related to the future climate, have been suggested (Dessai and Hulme, 2007; Hallegatte, 2009).

The provision of weather information can be considered a robust CCA strategy for the transport sector, as weather services are beneficial for road transport in the current climate and with current level of services. However, different processes in nature and society co-exist that shape the future of road transport; climate change is altering weather variability, whilst innovations in weather and climate services and technological development in road transport sector are changing the way services are provided and how the services are used by vehicle drivers, thereby affecting the overall safety of the road transport mode.

The use and value of current weather services in the road transport sector have been studied for instance in Frei et al. (2012), Nurmi et al. (2012) and WIST (2002) (see Section 5). Some research on 
how innovations, such as intelligent road transport systems (e.g. Innamaa et al., 2012; Ezell, 2010) can be used to increase the function of road transport in the future has been undertaken. Regarding weather services, much of the research has focused on the development of specific technologies to improve these services, such as using vehicles as observation devices (Drobot et al., 2012) or developing new communication channels to reach the drivers (Roine, 2010).

\subsection{Aim and objectives}

Innovations in weather services and consequent increases in the benefits of weather services have the potential to improve the resilience of the transport sector to the expected adverse impacts of climate change. The aim of this study is to evaluate how potential innovations in weather services can reduce weather sensitivity and, consequentially, decrease the negative effects of climate change in the transport sector, and particularly the road transport sector.

The study focuses on the road transport for two reasons. Firstly, it is the most vulnerable transport mode to extreme weather, at least if assessed in terms of the aggregate costs related to extreme weather events (Nokkala et al., 2012). Approximately 10\% of the road accidents can be attributed to extreme weather events (Nurmi et al., 2012) which translates into extreme weather related losses of over 20 billion euros per year in Europe (Nokkala et al., 2012). Secondly, it serves as a good example to illustrate how innovations in the provision and use of weather information can prove to be beneficial for adapting to the changing climate.

The objectives of this paper are to 1) identify and describe the main trends and potential innovations in the provision and use of weather services in the road transport sector (section 4); 2) identify where in the weather service provision value chain these innovations would have an impact on the use of weather information before and during the trip (Section 5); and 3) analyse the expected magnitude of the value of these innovations (Sections 5 and 6).

The overall purpose of this work is to contribute to the understanding of the overall effects of the improved weather service provision on the safety of road transport to improve climate change adaptation in the road transport sector.

\section{Weather services to support climate change adaptation in road transport sector}

\subsection{Climate Change Adaptation}

This paper utilises the approach provided in Smit et al. (2000) to systematically specify and characterise CCA. This approach is based upon responding to the following three questions: 1) Adapt to what? 2) Who or what adapts? 3) How does adaptation occur?, which are outlined below.

\section{Adapt to what?}

The uncertain, and changing, extreme weather patterns are considered to be the most urgent threat to road transport (see Section 1). Direct impacts of climate change will occur due to, for instance:

- changing freeze/thaw cycles, which will affect winter road maintenance costs and accidents rates (Andersson and Chapman, 2011);

- changing precipitation patterns affecting rainfall, flooding, snow and visibility, which may affect the number of road accidents (Jaroszweski and McNamara, 2014; Jaroszweski et al., 2010; Qiu and Nixon, 2008) and congestion (Koetse and Rietveld, 2009);

- increase in the intensity in hot spells which could increase the accident risk due to psychological and physiological effects (Laaidi and Laaidi, 1997); and 
- increase in strong winds, which have a potential adverse effect on road safety (Thordarson, 2006).

2. Who or what adapts?

The most suitable adaptation strategies to climate change are defined by the system in question and its characteristics. The system itself and its need to adapt are defined by various determinants, which measure for instance the vulnerability, resilience and adaptive capacity of the system to climate change. In the road transport sector, different responses are required at operational and structural levels. At the operational level, the role of the vehicle driver is prominent, although adaptation at the infrastructure level, for instance relating to traffic flow management, may become necessary as well. Vehicle drivers respond to quickly unfolding extreme weather events with short lead-times by adapting departure time, changing the route, switching travel mode, and by cancelling the trip. To long-term developments, vehicle drivers can respond by adapting their decision on vehicle ownership, by moving residence or changing a default shopping location. (Hensher and Brewer, 2000; Polak and Heertje, 1993)

At the structural level, measures regarding the capacity, location, and technical standards of transport infrastructure are required. The focus of this paper is the use of weather services as a robust adaptation measure; therefore, CCA is not assumed to take place at the system level, but to be implemented at the level of the user, as vehicle drivers are vulnerable to climate change effects due to changes in the extreme weather patterns.

3. How does adaptation occur?

Adaptation can refer to both natural and manmade systems and may entail both autonomous adaptation, in which a system responds to climate change spontaneously, and planned adaptation, in which deliberate adaptation strategies are developed and measures implemented. This is linked to the timing of adaptation, which can happen prior to any impacts (anticipatory), while the impacts are occurring (concurrent) or be reactive and take place only after the impacts have occurred. Furthermore, adaptation to climate change can be either incremental, if the system is changed by merely extending the current practices which are used to adapt to weather events, or transformational, if adaptation entails far reaching changes in the considered system. (Carter et al., 1994; Smit et al., 2000; Kates et al., 2012)

Due to the uncertainty of the extent of climate change in the future climate (Vajda et al., 2011) and the aforementioned impacts, robust (i.e. valid in many scenarios), yet adaptive, adaptation strategies may be a wiser approach as compared to major infrastructure investments (Dessai and Hulme, 2007). This consideration is based on option value theory, for instance "the benefit derived from keeping options open so as to be able to adjust policies in the light of better information" (Ingham et al., 2007) and to avoid sunk costs (Hallegatte, 2009). With regards to robust adaptation strategies, Hallegatte (2009) suggests the following: No regret measures which create benefits even in the absence of climate change; Reversible measures which are easily retrofitted if climate change projections turn out to be wrong; Safety Margin measures which reduce the vulnerability of the system at a low or no-cost; Soft measures which can be institutional or financial; Reduced time horizon measures which involve reducing the lifetime of an investment; and strategies which have Synergies with mitigation.

A further classification of adaptation measures is proposed in Perrels et al. (2013a). This classification is based on whether the measures are to reduce (1) exposure; (2) vulnerability, or to (3) improve (active) resilience. Improving weather information belongs to the third category. Due to its 'active nature', it blurs the distinction between planned and automatic adaptation, and thereby it may also link incremental and transformational adaptation. As Rotmans and Loorbach (2009) indicate, transformations cannot be fully planned, but can be promoted and facilitated inter alia by enhancing automatic adaptation capabilities through innovations. 
This study builds on these definitions and observations and aims to identify to what extent innovations in weather services can help to improve anticipatory, planned adaptation to climate change in the road transport sector, whilst at the same time open up options for more fundamental changes (transitions) in the system. A key element in this respect is the provision and use of weather information so as to enhance well informed decision-making.

Weather information is beneficial for the road transport sector only if successfully used. Therefore, innovations in weather services should focus on the entire weather service chain (including forecasting, information tailoring, media choice, access, comprehension, leeway for response, benefit retention) in order to maximize the leverage of the improvement efforts. (Perrels et al., 2013b)

\subsection{Weather Service Chain Analysis}

Weather services can be considered a robust, no-regret adaptive CCA measure, as they provide active resilience in current and future climates. For instance, Hallegatte (2009) suggests that early warning systems are a 'no regret', reversible, and soft measure to respond to climate change impacts.

Weather information can be understood as a factor in a decision process aimed at maximizing the value or utility of a considered process or activity. A hypothetical maximum benefit potential of meteorological services can be estimated, assuming that perfect initial information (e.g. perfect weather forecast) is combined with $100 \%$ use among end users and 100\% effectiveness of their responses. However, the actual level of realised benefits depends on the quality of the information, and the timeliness and ability of the involved users to respond to the information. (Perrels et al., 2013; WMO, 2012)

The actual value of the initial meteorological information stems from the use of the information and the extent to which the end users are able to interpret and use the information and transfer the benefits to other agents. An important aspect in the approximation of the actual level of realised benefits is the information decay in the service chain. Weather Service Chain Analysis (WSCA) (Nurmi et al., 2013) aims at accounting for the inadequacies in the dissemination and use of weather information. The approach describes the decay of the benefit potential based on a decomposition of the information flow, ranging from information generation to benefit realization for the end-user and society as a whole.

This approach has been used extensively in section 5, in which each step (apart from 7 which would require macro-economic analysis) is analysed with regards to how vehicle drivers are able to use and benefit current and improved weather information. WSCA can be used in a semiquantitative way indicating orders of magnitude of improving potentials per step (which can be related to managerial actions aiming at that step). WSCA can also be used in a more formalized fashion, resulting in estimated fractions, e.g. for the purpose of cost-benefit analysis of a weather service. The seven steps of the WSCA assess the extent to which:

1. Hydro-meteorological information is accurate [accuracy];

2. Information contains appropriate data for a potential end user [appropriateness];

3. The end user has (timely) access to the information [access];

4. The end user adequately understands the information [Understanding];

5. The end user responds to the information to effectively adapt behaviour [responsiveness];

6. Responses actually help to avoid damage or improve operations [response effectiveness];

7. Benefits from adapted action or decision are transferred to other economic agents. 
The estimate of the overall effective avoidance share $Q$ can be calculated with the following equation; bearing in mind that the linear structure of the model gives only an approximation of the value decay in each step $\left(S_{1} \ldots S_{6}\right)$ :

$$
\mathrm{Q}=\prod_{s=1}^{6}\left\{S_{i}\right\}
$$

The weather service market is essentially based on observing and predicting weather and effectively communicating the produced information to users. While this structure remains, in the process of innovation the components of the market undergo changes. The technology develops, enabling improved level of both temporal and spatial accuracy, and meanwhile also the communication channels develop and change. As Bayesian decision-theory suggests, improved level of information only brings incremental value if it has an effect on the decisionmaking (Katz and Murphy, 1997).

Consequently, we use WSCA in conjunction with decision-analysis by analysing the decisionmaking process of the vehicle drivers. This approach requires mapping of the following information: (1) relevant decisions for a user (or user group) for which weather information has a differential effect; (2) need to identify what are the relevant future possible events that may occur and the economic consequences of those; (3) how well the different stages of the WSCA are realized at the moment, and (4) which parts of the chain will or should develop in the future to create economic benefits. ${ }^{7}$

\section{Methods and data}

Semi-structured interviews were performed to identify the trends and potential innovations in the provision and use of weather services and analyse the value of these innovations in the weather service provision value chain. Semi-structured interviews have a planned interview guide, but are open to new topics, as it allows exploring of new areas emerging during the interview (Gillham, 2005). The interview guide used was designed based on the WSCA, described in Section 2.2. Altogether 12 semi-structured interviews were undertaken during the spring of 2013 by the two first authors of this paper.

Out of the 12 interviewees, eight represented a national hydro-meteorological service (NHMS) and were experts on weather and transport, or service or business development. Requests for interviews were sent to several European NHMSs, and interviewees were selected in order to obtain a balanced representation of all aspects of meteorological and climatological development. Furthermore, three experts in the areas of weather observations equipment and related technologies were interviewed. In addition, a winter road maintenance company was interviewed to gain an understanding of the link between weather information and road-users. The winter road maintenance company is one of the two big players in Finland that share regional maintenance contracts. It has an almost identical operational structure to that of many countries, for instance, in Sweden, Norway and Canada. Individual driver behaviour was analysed through literature (Sihvola and Rämä, 2008; Cools and Creemers, 2013).

The purpose of the interviews varied according to the stakeholder category:

- NHMS: to identify the services provided for road transport sector and the main trends in new meteorological services;

- weather forecast model developer (European Centre for Medium-range Weather Forecasts): to determine the expected future capabilities of weather models and their dependence on the investments;

\footnotetext{
7 A classical reference for decision analysis approach regarding weather information is Katz and Murphy (1997)
} 
- weather observations equipment supplier: to determine the development of the observation network as an enabler of more spatially accurate weather information;

- expert/professor on information, communication and networking technology: to understand technological development and innovation processes in information and communication technology, particularly related to weather service provision

- Interface between weather service provision and road users: to understand the current use of weather and climate information to ensure safe driving conditions for the vehicle drivers, the need for improved information and how climate change is expected to change the operational environment and data needs.

All interviews were transcribed verbatim and coded and analysed independently by the first two authors of the paper. The interviews were coded with respect to three aspects: 1 ) who is the target or the user of the innovation in the weather service provision (road maintenance companies, professional drivers and normal vehicle drivers); 2) what type of weather or climate forecasting is the innovation expected to improve (nowcasts 8 , short-range weather forecasts [up to 72 hours], medium-range forecasts [up to 10 days], monthly forecasts and seasonal forecasts); and 3) in which step of the WSCA is the innovation considered to be relevant (introduced in section 2.2).

\section{Foreseen innovations in weather services}

Based on the results of the semi-structured interviews, the overall trends and innovations in meteorological services up to 2030 can be classified into three categories: observation technology, global weather models and information and communication technology (ICT).

\subsection{Observation technologies}

Observations (either with radar instruments, meteorological satellites or mobile devices) are the starting point of any meteorological work and an important factor behind improved weather forecasts is a dense and reliable observations network. Therefore, innovations in the coverage and reliability of observational instruments are highly significant in determining the future capabilities of weather forecasts.

The current state-of-the-art radar technology is the dual-polarization radar, which observes both the amount and type of precipitation - being water, sleet, snow or hail. All new radars installed in developed countries are dual polarization radars. As of 2013, 40 out of the 200 radars in Europe have already been updated. The remainder are expected to be replaced by 2025 .

Adaptive radar networks, which allow multiple radars to flexibly follow the development of a relevant weather phenomenon, reduce prediction uncertainty in nowcasting. More reliable nowcasting enables decision-makers to make better decisions in situations in which the costs of the incident, but also those of false alarms are significant. (McLaughlin and Chandrasekar, 2009)

The improvements in the satellite observation systems in the past two decades have been a crucial driver behind the steady extension of the reliable forecast period. Future improvements in satellite systems can be expected to continue this trend. However, growing uncertainty about funding of these future systems seriously challenges the assumed trend.

The further development of retrieving and analyzing mobile observation data was emphasized by the interviewees. Mobile observations include observations from vehicles e.g. data from the windscreen wipers or braking systems, and observations made by individuals with mobile devices. These observations can be automatically collected data in a specified format. A novel approach is to compose informal data points such as pictures or status updates posted in social

\footnotetext{
8 Nowcasting concerns very short term weather forecasting $0-4$ hours ahead at high spatial resolutions (such as road segments) (Browning, 1980)
} 
media (e.g. Hyvärinen and Saltikoff, 2010; Muller et al., 2015). Due to the possible quality problems with this kind of data, it either requires validation or it can be used for validation purposes.

Data fusion means that observational data from different sources, for example measurements from weather stations, road-side rainfall measurements and lightning data is combined and analyzed in conjunction with radar data. Consequently, integrated measurement networks would provide a better picture of the state of the atmosphere. Open data policies, such as the INSPIRE directive by the European Commission (European Parliament and Council of the European Union, 2007) will enable also private weather companies to develop tailored applications based on data fusion.

\subsection{Global weather models and forecast skill}

The performance indicator representing the capability to predict meteorological conditions is indicated by 'forecast skill'. Nurmi et al. (2013) suggest that atmospheric predictability has improved approximately by 1-day-per-decade during the last 20 years; which was confirmed by ECMWF. Generally, for a given season and area, temperature forecasts tend to perform better than precipitation forecasts. The 1-day-per-decade development is a baseline for the expectation of the development in the future, but it requires some assumptions on technological development and policy measures. The biggest threat to the continuation of this improvement rate stems from research and development budget constraints. The development depends largely on the following three factors:

1. Computing power: with faster computers, models can run at higher resolution and phenomena that happen in the atmosphere can be better resolved. The decreasing cost of processing power also enables more sophisticated observation and data transmission instruments and in general lowers the price of all data processing.

2. Observation infrastructure, especially meteorological satellites: Running models at a higher resolution requires higher resolution satellite data, which requires maintaining a sufficient satellite fleet and systematic renewal of obsolete satellite instruments. For shorter range forecasts, conventional observations systems are more important, requiring investments in this infrastructure as well.

3. Computer models, and general meteorological research: Research is required on the interactions between the atmosphere, land (e.g. vegetation) and ocean and on running the models in an efficient way. Furthermore, the utilisation of the advancements in computing power requires development of more sophisticated models.

In addition to temporal accuracy, also the spatial accuracy of global models has been increasing steadily. ECMWF expects to run their global forecast system in a 10x10 kilometre grid within the next five years and perhaps in a 1x1-kilometer grid in 10-20 years. Current regional very highresolution models run in a 3x3-kilometer grid. As the spatial accuracy of these models and predictions increases, the role of NHMSs could change, as they are currently the main providers of regional weather forecasts. This could lead to significant rearrangements in the division of responsibilities between different service providers; public and private alike.

\subsection{Information and communication technology}

As mentioned, ICT has a key role in the development of weather and climate services. Improvements in weather forecast accuracy are partly enabled by advances in computational capabilities. Smoothly working telecommunications are critical for the timely access to weather information; the use of mobile observations increases the reliance on communications even further as the data has to flow in two directions. Combining spatially and temporally accurate weather data with other context-dependent information requires both abundant transmission and processing capacities. 
Advances in electronics have enabled the continuing reduction of unit costs in computing and telecommunications. The physical limits of current transistor technologies are acknowledged, but the exponential development is expected to continue in the following decades (Cavin et al., 2012). Thus, the development of computational performance is likely to support improvements in forecast accuracy also in the future. There are, however, other technical challenges that may affect the course of weather service innovation. Firstly, congestion of mobile networks is worsening as both the amount of mobile devices and the popularity of data-intensive services increases. Technological development alleviates the problem to some extent, but the spectrum itself is limited. For example maintaining a reliable road weather service might require specific policy decisions at some point. The second challenge is the growing energy demand of the mobile devices. More advanced network technologies require more advanced signal processing from the device. This, together with the higher capabilities of the devices regarding their computational power, display quality and other features translates into rising power consumption. Although the issue could be addressed with improvements in battery and charging technologies, a more fundamental problem is caused by the waste heat that needs to be dissipated. This problem is however less relevant for road weather systems if the end-user devices are part of the vehicle.

Any advanced road weather system needs to combine and process data of various sensors and sources. Foreseen technological development enables further advancements in such systems, but the aforementioned challenges are likely to guide their design. In light of the challenges, the road weather systems are likely to be centralized (data gathering and processing taking place in a remote service centre) instead of decentralized (data gathering and processing taking place in the vehicle). The configuration of the system will also affect the business models and the diffusion pattern of the services.

\section{Innovations in weather services as a means of adaptation in the road transport sector}

The use of weather and climate services is closely intertwined with the evolution of a road transport sector's coping range with respect to prevailing weather conditions. Consequently, investment in weather services is beneficial regardless of the realized future state of both climate and society and is, therefore, a robust adaptation measure. The development of weather and climate services can expand the amount of cost avoided, and/or enable improvements in conjunction with product or process development in the road transport sector. This means that adaptation to climate change will be affected by the socio-technical innovations in weather and climate services.

The responses arise either when the weather condition becomes apparent or when the information about the current/future weather conditions reaches the decision-maker. There have already been positive findings suggesting that these measures can decrease the economic sensitivity of the transport sector to weather conditions (Lazo et al., 2011; Nurmi et al., 2013).

This section shows how innovations in weather services can enhance these decisions and increase the benefits of the information for the users. Using the first six filtering steps of the WSCA, we analyse how the investment in weather service capabilities affects the ability to respond to adverse weather conditions. This is done by analysing pre-trip and en-route adjustments. The current level of each step is analysed mainly from the results of the relevant literature, while the innovation prospects and service development were collected from semi-structured interviews (section 3).

Ideally, the (accurate) weather information should be available for the vehicle drivers at the latest on the evening before the trip because they request knowledge about the relevant weather parameters 6-12 hour prior to trip to be able to modify their travel plans (Nurmi et al., 2012; WIST, 2002). On a shorter lead-time, the modifications are more of a reactive nature, such as 
selection of a different route (Cools and Creemers, 2013). The relevant weather parameters, which climate change is projected to have an effect include at least snowfall, precipitation, temperature, wind gusts and hail (Vajda et al., 2011; Jylhä et al., 2009).

In addition to pre-trip decisions, vehicle drivers can adapt to current weather information by making en-route decisions. Rather than a static decision, an en-route decision is a recurrent or even continuous series of decisions related to driving speeds, effective route choices, stoppages, safety margins and overtakes. Results from earlier studies suggest that on-road driving behaviour is predominantly affected by the prevailing conditions rather than traffic weather forecasts (Kilpeläinen and Summala, 2007; Nurmi et al., 2012; De Palma and Rochat, 1999). However, it seems that up-to-date information during the trip can have a larger impact on the drivers' response. Consequently, the most important meteorological information are nowcasts and observations from road weather stations. The methods for improvement of the efficiency of on-road decision-making should be spatially very accurate, technical by nature and give clear messages of effective/suggested measures (Kilpeläinen and Summala, 2007). These measures could shift the en-route weather information from static weather maps to dynamic decisionmaking tools such as adaptive route-choice tools.

\subsection{Step 1: Accuracy of relevant weather parameters}

Based on indirect verification methods (Sihvola and Rämä, 2008), 92\% of the days with very poor weather conditions are at the moment forecast already on the previous evening.

\section{Pre-trip decisions}

Often, weather parameters relevant for vehicle drivers are combined in a road weather model, which employs as an input a numerical weather forecast and observations from synoptic weather stations, road weather stations and weather radars. The model produces a forecast of road conditions (e.g. friction and visibility), which can be categorized for instance in three classes; 'normal' which implies normal driving conditions and is disseminated as a regular forecast, 'difficult' and 'very difficult' which are disseminated as warnings to the public. Based on an indirect verification of the quality of the extreme winter weather warning system in Finland, warnings are successfully issued on days with a distinctly high accident rate; 19 out of 21 of the days with highest accident rates had been forecast on the evening before (Sihvola and Rämä, 2008), indicating that existing road weather models are fairly accurate in predicting the worst accident days. Direct verification is difficult since no objective measures for poor or very poor road conditions exist.

However, Juga (2012) suggests that a surprise factor due to a missed adverse weather event by a forecast is an important determinant in accident rates, implying that no warning can result in very high accident rates on a given day. Furthermore, Sihvola and Rämä (2008) found that poor or hazardous road weather conditions had been forecast on days when the realised accident rate remained low.

Due to the non-linearity suggested in Juga (2012) and false alarms detected in Sihvola and Rämä (2008), the improvement in the temporal accuracy of road weather models can result in large economic savings, as the forecast at the time point of the requested lead-time (6h- $12 \mathrm{~h})$ is becoming increasingly accurate as discussed in section 4 . As an interviewee pointed out, this increases in importance due to the projected climate change-induced increase in weather variability and potential increase in the surprise effect.

\section{En-route adjustment}

The most important feature of meteorological information for en-route decisions is spatial accuracy of road condition nowcasts. Of the NHMSs interviewed, two considered the quality of the observations from road weather stations as 'good'. However, the weather station network often is not of the required density, is only concentrated in densely populated areas or is along 
the main road network. As mentioned by two NHMS interviewees, this greatly challenged the feasibility to produce spatially accurate forecasts and nowcasts.

To tackle this issue, the technology supplier and the NHMSs suggested two main improvements in observation technology. Firstly, the technology supplier noted that less expensive technology, in the form of remote road surface state sensors which enables a denser observation network, has been developed. The installation of these devices is expected to start well before 2020. Secondly, mobile observations have the possibility to create a denser observation network, as for instance vehicles can provide information on road slipperiness from the tires and precipitation volume from the windscreen wipers. NHMSs suggested that this process is likely to happen in the next ten years. However, to maintain quality standards of the localized forecasts, verification of the mobile observations with the nearby (road) weather stations is required. Further development, where cars could communicate weather information to each other without a meteorological service as an intermediate, is in progress. Without verification and quality check by a meteorological service, these services can turn out to be problematic. Furthermore, adaptive radar technology and data fusion introduced in section 4 will enable spatially more accurate nowcasts. The new applications will be available in the next 5-10 years (2020-2025).

\subsection{Step 2: Appropriate data}

Based on the literature review and NHMS interviews, the three-level-index about the road conditions is considered sufficient but not exhaustive information by the vehicle drivers. There is demand for route specific information and combination of road condition data with other relevant data (e.g. road blockages). Current skill rating is still around $90 \%$, since based on interviews and literature (Sihvola and Rämä, 2008) the road weather warnings would already enable informed decisions, if utilised accordingly (see steps 4-5).

\section{Pre-trip decisions}

The three-level road weather forecast and warning system is well understood and intuitive to vehicle drivers, according to a user survey conducted by one of the NHMSs. However, according to the survey, vehicle drivers would like to obtain more specific information on the actual timing of the adverse weather, as current road weather warnings usually show similar adverse conditions for the next 24 hours, and more specific information on the actual location of the weather event. This demand was specifically mentioned by two other NHMSs interviewed. However, this demand creates a challenge for the communication as giving detailed temporal information via the traditional dissemination channels (e.g. TV, radio) would require showing multiple weather maps, longer air-time for weather forecasts and harder interpretation of the information. New communication channels, mainly internet and mobile applications are being studied, and new services are expected to emerge in the following years in many countries. This, combined with the improvements in forecast accuracy, enable more time and location specific information.

Route-specific forecasts are already available for road maintenance purposes. These will reach the public in the upcoming years as they are being developed in three of the interviewed NHMSs. In Spain, a pilot project on route-based forecasts for three test-case highways has been implemented through an EU FP7 funded project called FOTsis (www.fotsis.com/).

In addition to weather conditions, more informed pre-trip travel decisions should take into account other relevant information, such as road blockages (e.g. construction work, summer festivals etc.) or expected amount of traffic, pointed one of the NHMSs. An example of such data combination is offered by the Bavarian traffic information agency (Bayerninfo-see http://www.bayerninfo.de/planner) which, next to weather information, offers information on real-time events, traffic conditions, travel times and multi-modal services (Scheider et al., 2010).

In Finland, new services that combine data from different sources, and new online and mobile applications that would enable the technical execution, have been planned. In the UK, Met Office 
has a system which is designed to forecast weather for different routes for road maintenance purposes. It is based on the road weather model of the UKMET, but has a much higher spatial resolution and accounts also for non-weather factors. These services are not available to the public yet, but are expected to be opened for wider use before 2020 and will likely to be integrated to other route-planning tools in the future (2020-2030).

\section{En-route adjustment}

Since drivers tend to underestimate the severity of driving conditions compared to what expert reviews or road weather station information would suggest, bringing up-to-date information of the current road conditions to the vehicle drivers is important. Especially the slipperiness of the road surface is a challenging parameter for the vehicle drivers to estimate through their own perception. (Kilpeläinen and Summala, 2007).

A combination of appropriate road condition, weather data and relevant data from other sources, and effective real-time communication to the vehicle drivers is at the heart of Intelligent Transport Systems (ITS). For instance, one of the interviewed NHMS mentioned that layer-based technology will allow users to select the relevant weather and other parameters to be shown on the screen of a navigation system. An EU FP7 funded project ROADIDEA which studied innovations in transportation, listed this as the main development target in the near future. Furthermore, inaccessibility of data and the location of data collection and calculation were listed as the main barriers for development. (Roine, 2010) ITS was mentioned as an important field of research in the interviews. The development is a high priority for NHMSs (2015-2020), but also for many private weather companies.

The driving and management control in road transport is increasingly integrated into technical systems which adjust to different driver needs. The vehicle infrastructure integration enables either vehicle-to-vehicle or vehicle-to-infrastructure communications and has the potential to improve the information provided to drivers (Petty and Mahoney, 2007). A leading global example is a real-time in-vehicle traffic information system called Smartway in Japan which reaches over 34 million drivers. Japan invests over 500 million euro annually into ITS (Ezell, 2010). In the European Union, smart transport solutions are applied; however, in a fragmented manner, in mono-modal instances, in geographically isolated domains, and incompletely (European Union, 2011).

Implementation of ITS requires intensive cooperation between public authorities, regulators, the automotive industry, road infrastructure management, NHMSs and/or private weather information companies, cloud service providers and other agents in the evolving field. This change does not take place instantly and without significant investments in Europe (2020-2040). Meanwhile, the development of "traditional" sources of information such as radio, satellite navigation devices (-2020) and mobile applications (-2020) will be important.

\subsection{Step 3: Access to weather information}

Currently, approximately $60 \%$ of the drivers have actively or passively received weather information prior to their trip (Cools and Creemers, 2013; Sihvola and Rämä, 2008).

\section{Pre-trip decisions}

Traffic weather information systems should be easily accessible to drivers and used by a considerable proportion of them to have an effect on traffic safety and pre-trip decisions. In principle, information is accessible to everyone constantly through various channels: radio, television, internet and mobile applications for different platforms. However, according to road side surveys, user rates for road weather information remain somewhat low (Kilpeläinen and Summala, 2007; Sihvola and Rämä, 2008). In a road side interview by Sihvola and Rämä (2008), $62 \%$ of the drivers had actively looked or passively received weather information prior to the trip. In Belgium, a study found that $60 \%$ of the respondents acquired weather information on a 
daily basis; television being the most important medium. However, the choice of media did not play a significant role in the travel behaviour. (Cools and Creemers, 2013). Furthermore, Kilpeläinen and Summala (2007) find that especially young adults are hard to reach via traditional channels. Therefore, we conclude that currently at least $40 \%$ of the vehicle drivers are not familiar with the road conditions prior to a trip.

Push-based mobile applications were identified by interviewees as one innovation to better reach the public. The applications would use the location of the mobile device and send messages to mobile phones either via pre-installed, which would require cooperation with telecom operators, or downloaded "apps", which would require an active decision from the user to install the app and allow it to send push-messages. However, a steady increase in the use of mobile weather applications has been witnessed in Finland (Harjanne and Ervasti, 2014), and based on a survey undertaken in Canada (Silver, 2014), along with telephone calls, text messages and "Cell-phone pop-ups" were seen as the most preferred media to disseminate weather warnings. Therefore, the potential of the push-based messages can be regarded as substantial. Indeed, several new applications are being developed particularly bearing the hard-to-reach young adults in mind. These services will most likely be available in the near future (2015-2020).

\section{En-route adjustments}

En-route weather information is still usually based on traditional car radio system. However, two of the NHMSs interviewed are developing nowcast-based weather warnings that will be communicated to satellite navigation devices. This service is already available in one of the interviewed countries, but only for specific navigation devices. In the other two NHMSs these services were considered to be something that commercial companies should provide.

Services for mobile devices are also being developed. However, the safety aspects of using mobile devices need to be considered; for instance Drews et al. (2009) found that dialling or reading text messages from mobile devices is riskier than speaking on the phone or even driving intoxicated. Thus, mobile services should be developed so that the driver does not need to actively search or even read information. Push-based applications with voice alarms, which would warn automatically if the driver is approaching adverse weather conditions or other disturbances in traffic, are being developed. (2015-2025).

\subsection{Step 4: Comprehension of the information}

Approximately $85 \%$ of the drivers that had acquired road weather information considered it easy to use and interpret. Studies also show that road weather information has the ability to improve drivers' perception of the actual road conditions. (Sihvola \& Rämä 2008; Kilpeläinen \& Summala, 2007).

\section{Pre-trip decisions}

Sihvola and Rämä (2008) suggest that those who had acquired weather information considered it easy to interpret and use. The stakeholder interviews confirmed this fact, revealing that comprehension of the three-level forecast and warning system is not a problem for users.

\section{En-route adjustments}

Studies show that the drivers who receive weather information before the trip have a more realistic perception of the road conditions than other drivers. (Kilpeläinen and Summala, 2007; Sihvola and Rämä 2008).

In general, drivers tend to rate the driving conditions to be better than the forecasts or actual observations indicate. Therefore, en-route information can improve drivers' judgement about the current conditions, especially if it is considered more reliable than driver's own perception of the weather (Kilpeläinen and Summala, 2007). 


\subsection{Step 5: Ability to respond timely and effectively}

Sihvola and Rämä (2008) and Kilpeläinen and Summala (2007) show that about one third of those who had acquired weather information prior the trip, had actually changed their travel plans. These studies did not reach those drivers that had already cancelled their trips. Cools et al (2013) finds that $45-60 \%$ of vehicle drivers did not respond to weather information; the precise percentage depending on the purpose of the trip. Therefore, a conservative approximation of this step falling between $33 \%$ and the average of $45-60 \%$ is $40 \%$.

\section{Pre-trip adjustments}

In Sihvola and Rämä (2008), one fifth of the drivers had made or had considered making changes to their travel plans based on weather forecasts. In Kilpeläinen and Summala (2007), only 6 \% (or one third of those who had acquired weather information) of the drivers reported any changes in travel plans before or during the trip. This study, however, did not reach those who had already cancelled or postponed their trips. Both studies found that approximately one third of those who had acquired weather information prior to the trip had changed their travel plans, and neither of them included those who had cancelled. The most common change was reserving more time for the trip. (Sihvola and Rämä, 2008; Kilpeläinen and Summala, 2007)

Cools et al. (2013) studied the response of vehicle drivers to weather information via questionnaires in Belgium. They found that the response is heavily dependent on the purpose of the trip and the forecasted weather phenomenon. Of the shopping and leisure related trips, a far greater share of the respondents were ready to cancel the trip in case of forecast of bad weather (over 30\%) than of the work or school related trips (under 10\%). The study showed that people react with high variation to different forecast weather phenomena, in particular more strongly to those weather phenomena that they are not used to.

Based on the interviews, NHMSs acknowledge the problem of low response rates. Response rates can be improved with clearer messages and cooperation with other institutions, such as the police. For example, if extremely poor weather conditions are forecast several days ahead, the warnings can be issued on television channels (although in some countries this is not possible) and other media partners can be informed. The police can advise people to leave their own cars home or work from home, if possible. One of the interviewed NHMSs stated that they have already seen success in the cooperation with the authorities, as the amount of traffic has been significantly reduced during those days that warnings have been distributed actively with authorities mainly in national news. An example of a social innovation is the possibility of replacing work trips by collaborative technologies and working from home when needed. According to a study about New York in 2030, 30\% of the commuters would have the possibility to stay home in the case of poor weather. The possibility for telecommuting is likely to improve the ability to respond with trip cancellations (Ukkusuri and Ramadurai, 2009).

\section{En-route adjustments}

Driver responses to weather information acquired before the trip are non-existent based on Kilpeläinen and Summala (2007) or of too low magnitude based upon De Palma and Rochat (1999), Sihvola and Rämä (2008) and Rämä and Kulmala (2000). However, up-to-date information on the road can have a larger impact on the driving behaviour (Kilpeläinen \& Summala, 2007).

Consequently, examples of measures to improve the response of drivers include standardized variable message systems that display concrete driving behaviour instructions (Kilpeläinen and Summala, 2007), such as maximum allowable speed or painted signs on the road surface that are only visible in specific conditions (implemented in the Netherlands, (Clark, 2012)). Other measures could include push-based instruction from mobile or satellite navigation devices or integrated decision-making systems on vehicles. The latter type of options are expected to be implemented in a somewhat more distant in the future (2020-2040). Based on the interviews and Kilpeläinen and Summala (2007), spatially and temporally accurate warnings could improve the 
response of vehicle drivers as they would find the information more reliable than the earlier forecasts.

\subsection{Step 6: Actual effectiveness of the responses}

Responses, such as cancellations (Maze et al., 2006) or even small speed reductions (Nilsson, 1982), are efficient ways to reduce accidents. Nurmi et al. (2012) estimate this step to be $80 \%$, as responses, should they happen, are effective.

\section{Pre-trip decisions}

The effectiveness of responses is mixed (Stahel et al., 2014). Cancellation and postponing of trips are obviously effective ways to mitigate the effects of poor road conditions (Maze et al., 2006). Cancellations of trips are more common for leisure-related trips than work-related trips (Cools and Creemers, 2013; Chung et al., 2005). This suggests that leisure trips are much more sensitive to weather information and weather conditions than work trips. For example, in Kilpeläinen and Summala (2007), leisure trips were clearly underrepresented in the road side interviews during very poor driving conditions, suggesting that most of the trips had been cancelled or postponed. Other possible responses are mode changes and route changes. However, these are less frequently used than postponing (Khattak and De Palma, 1997; De Palma and Rochat, 1999). Admittedly, cancellation and significant postponement of a trip will entail disutility for drivers. Supposedly, a significant part of these costs are not monetized. Conversely, there may be also savings such as unconsumed fuel. These costs and benefits of rescheduling are not taken into account in section 5. The same applies for the secondary cost effects of responses discussed below.

However, other responses next to cancellations are not as successful: even though respondents stated that they had acquired information and sometimes even reserved more time for the trip, the prior acquisition of weather forecast information had no effect on on-road-behaviour, which can be better influenced by real time information (Kilpeläinen \& Summala, 2007). In other studies the prior acquisition of weather information has influenced the driving behaviour during the trip by small speed reductions (Khattak and De Palma, 1997; Sihvola \& Rämä 2008).

\section{En-route adjustments}

Even small changes in average speeds have a significant, non-linear reduction in the accident rates. Variable message signs controlled on the basis of automatic classification of road condition situation were found to reduce the winter-time accident risk by $13 \%$ and summer-time by $2 \%$ (Rämä and Kulmala, 2000). Nilsson (1982) found that a $1 \mathrm{~km} /$ hour reduction in average speed reduced the amount of accidents in motorways by approximately $3-4 \%$ and on roads with 50 $\mathrm{km} /$ hour speed limits the reduction was $4-6 \%$. Drivers are also found to comply with variable speed limits better than to conventional ones (Scheider et al., 2010). The integration of road weather information, mobile devises, cars and road infrastructure will enable coordinated responses in the future, some decades forward (2020-2040).

\subsection{Summary of the innovation prospects}

Table 1 summarizes the innovation prospects and combines the relevant expected improvements with the estimate of the uptake schedule. The estimates of the timing of the uptake and the current level of each step are based on the preceding analysis. The improvements are again categorized based on which step of the WSCA they are expected to bring improvements. 
Pilli-Sihvola, Nurmi, Perrels, Harjanne, Bösch and Ciari

Innovations in weather services as a crucial building block for climate change adaptation in road transport

Table 1. Summary of the innovation prospects between 2015-2020 and 2020-2030

WSCA steps 1-6

1. Accuracy

2. Appropriate data

3. Access

4. Comprehension

5. Ability to respond

6. Effectiveness of response
$-2020$

Development of road weather models; denser road weather station network; data fusion and more accurate knowledge of relevant parameters for now casting purposes. Current: $92 \%$

Development of route-based forecasting; Weather information combined with other relevant information; development of layer-based technology (user selection of relevant weather parameters on one map) Current: $90 \%$

Improved internet platforms; mobile applications; push-based applications; satellite navigation systems; Current: 0.62

Improved en-route information will enable better judgement on the current conditions; Current: 0.85

Variable message systems and road signs, concrete and spatially accurate advice from mobile devices and satellite navigation systems. Current: 0.4.

Current: 0.8
2020-2030

Adverse weather can be forecast 1 day earlier with the current accuracy; surprise events very rare; observations from cars to weather forecasts system, data fusion and adaptive radar networks will improve. Spatial accuracy of current observations and now casts

Route-based forecasting available; Relevant information processed and selected automatically for the vehicle drivers

Infrastructure, including weather services, communicates directly with the information system of the vehicle, ITS;

Changes in weather parameters automatically analysed by the information systems of the vehicles.

Telecommuting possible for a larger share of commuters.

Coordinated responses

Figure 1 shows the current level of each step, also given in Table 1. It also shows the estimated increases in the current levels for each step (baseline in Table 2). A tentative system response analysis for the future values is performed in Section 6.

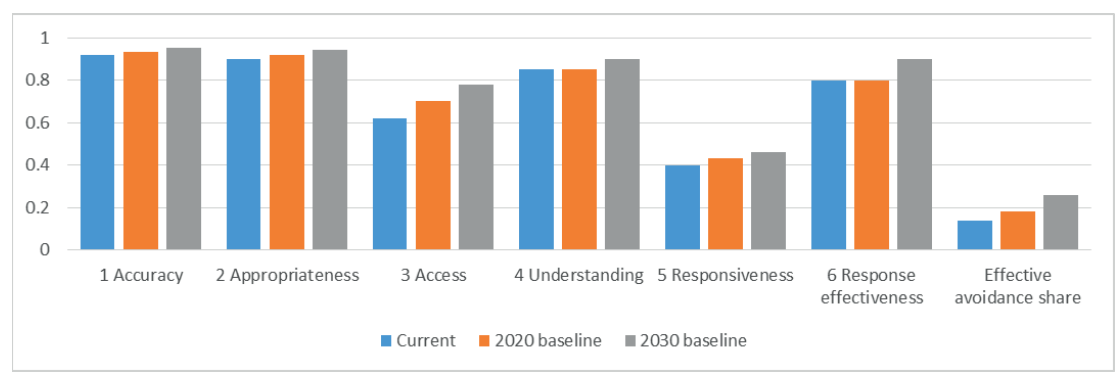

Figure 1. The current level of each WSCA step and the estimated increase in each step

\section{Discussion}

Road transport is facing two types of trends that are affecting the level of accidents in the opposite directions. The expected increase in the extreme weather related costs is interlinked with 
expected decrease of accidents costs due to technological and societal development (Nokkala et al. 2012). There are some estimates of the expected accidents costs taking both of these trends into account (Andersson, 2010; Nokkala et al., 2012) but due to high level of uncertainty of the future state of the sector, it is questionable to use these estimates for economic analysis. Nurmi et al. (2012) estimate that the annual accidents costs due to extreme weather in Europe are currently close to 24.4 billion euros. Consequently, this estimate of current accident costs is used in the sensitivity analysis for the magnitude of the annual savings of the weather service improvements. Nurmi (2012) estimate that only approximately $14 \%$ of the hypothetical maximum benefits of weather services (in terms of accident prevention) are currently realized at the end of the weather service chain in road transport. The estimate is based on the decay of value through the entire chain, expressed as product sum as explained in section 2.2. The constituting elements of the product sum, and the eventually resulting fraction realized are shown in Table 2 in the "Current" column. The exact formula of the effective avoidance share was introduced in section 2.

Table 2 presents a tentative system response analysis of how the improvements in the weather service chain would result into economic benefits. This can be viewed as the authors' best guess based on the innovation prospects and earlier experiences summarized in Table 1. The improvements in steps 2-6 in Table 2 are potential development pathways for weather services for road transport. We have developed two futures scenarios - baseline and high investment. The scenarios are developed based on the analysis presented in section 5. In the high investment scenario, progress in each step is defined to be twice as fast as in the baseline scenario. The improvement in step 2 is assumed to be modest due to the high initial value; however, based on the interviews, NSHMSs are putting effort on further improving this step. A larger improvement is assumed in Step 3 where innovations play a crucial role and several new ways to deliver information are being developed. In steps 4 and 6, no improvement is assumed in the baseline scenario until 2020, as this is heavily dependent on the end users and their behaviour. However, with further improvement in technologies, understanding and the effectiveness of the response will improve as more control is given to vehicles. The baseline of Step 5 is expected to improve earlier when more information is provided to the navigation systems.

In the base case, until 2020,18\% of the hypothetical maximum benefits are reached, and until $2030,26 \%$ of the hypothetical maximum benefits are reached. In the high case, until $202026 \%$ of the hypothetical maximum benefits are reached and until $203040 \%$. It is worth noting that this analysis is only done to illustrate how investments in weather services and respective innovations would translate into economic benefits as reduced accident costs. Other savings, such as time savings, should be added to the calculations; however based on earlier studies (Nokkala et al., 2012; Leviäkangas et al., 2007) those are likely to be small in value related to the accident costs. The system response analysis allows decision-makers to compare alternative investment strategies and/or conduct cost-benefit analysis of investment in projects altering the weather service chain. Consequently, the analysis is not meant to give accurate predictions of the future benefits, and the economic benefits should be interpreted as giving the expected magnitude of the future benefits given the chosen investment strategy. Also by manipulating different steps, benefits of investment in particular area of the weather service chain can be approximated.

The annual monetary benefits in the form of reduced accident costs are depicted in the last row. The disparity between base and high scenarios is around 2 billion euros annually by 2020 and already over 3 billion euros annually in 2030 . 
Pilli-Sihvola, Nurmi, Perrels, Harjanne, Bösch and Ciari

Innovations in weather services as a crucial building block for climate change adaptation in road transport

Table 2. Tentative system response analysis and resulting economic benefits

\begin{tabular}{|c|c|c|c|c|c|}
\hline WSCA steps & Current & $\begin{array}{l}2020 \\
\text { baseline }\end{array}$ & $\begin{array}{l}2020 \\
\text { high } \\
\text { investment }\end{array}$ & $\begin{array}{l}2030 \\
\text { baseline }\end{array}$ & $\begin{array}{l}2030 \\
\text { High } \\
\text { investment }\end{array}$ \\
\hline 1 Accuracy & 0.920 & 0.935 & 0.95 & 0.95 & 0.98 \\
\hline 2 Appropriateness & 0.900 & 0.920 & 0.94 & 0.94 & 0.98 \\
\hline 3 Access & 0.620 & 0.700 & 0.78 & 0.78 & 0.94 \\
\hline 4 Understanding & 0.850 & 0.850 & 0.9 & 0.9 & 0.95 \\
\hline 5 Responsiveness & 0.400 & 0.430 & 0.46 & 0.46 & 0.5 \\
\hline 6 Response effectiveness & 0.800 & 0.800 & 0.900 & 0.9 & 0.95 \\
\hline Effective avoidance share & 0.140 & 0.18 & 0.26 & 0.26 & 0.40 \\
\hline $\begin{array}{l}\text { Road accident max. damage } \\
\text { potential }\left(10^{9} €\right)^{*}\end{array}$ & 24.4 & 24.4 & 24.4 & 24.4 & 24.4 \\
\hline $\begin{array}{l}\text { Prevented damage } \\
\text { costs/year }\left(10^{9} €\right)\end{array}$ & 3.4 & 4.4 & 6.3 & 6.3 & 9.8 \\
\hline
\end{tabular}

Table 2 shows that currently the largest gaps in the benefit realisation are related to WSCA steps 3 (access to up-to-date information) and 5 (ability to respond). A large share of the drivers does not acquire weather information prior to their trips and during the trip base their opinions about the weather conditions mainly to their own observations. Therefore, the development in the communication technology is a key driver in this step. New ways to reach the vehicle drivers, such as new applications on mobile devices, services for satellite navigation devices and variable message systems are being developed. On the other hand, based on past studies, it seems that the responses to weather warnings are of too low magnitude both prior and during the trip.

So what are the key investment decisions that affect the realized future scenario and the economic benefits? Policy instruments and economic constraints affect the speed, magnitude and the direction of the innovation. This impact of economic activity and policy on development and diffusion of new technologies can be labelled as induced innovation (Nordhaus, 2002). The innovations in road weather services are likely to rely on policy decision in two key ways. First, the development in weather services is highly dependent on enabling core technologies, especially ICT and space technology. The advancements in these technologies are often results of publicly funded basic or applied research or research infrastructure. Thus, public investments are necessary to support the research and development work on which the future road weather services is built on. Second, many of the components in the current and envisioned road weather services are directly reliant on public funding or regulation. The weather observation infrastructure as well as the road infrastructure in general is likely to remain publicly funded. Advanced systems require working high-bandwidth communications across large areas that contain both densely populated urban areas and scarcely populated rural locations. Ensuring reliable communication in these conditions likely requires prioritization on policy level in situations in which the data traffic is congested and subvention in areas where the market is small or undeveloped. Yet, although the development is highly policy dependent, the private sector has a major role in producing and diffusing technical and practical innovations. Preferred policy is then such that it involves industry in developing new services and aims to create incentives for companies to create novel solutions for road weather services. 


\section{Conclusions}

Based on both literature review and the user survey, the expected changes in weather variation and in the extreme weather patterns seem the main threats that climate change poses to transport sector in Europe. However, keeping in mind both the high level of uncertainty in climate predictions and the fact that users of transport modes mainly react to adverse weather at the operational level or at the tactical level, costly alterations in transport infrastructure is not likely to be the most efficient adaptation strategy. Consequently, an important part of CCA in transport sector goes through processes that enable better operational and tactical level decision-making in adverse weather situations. Innovation in weather services is a crucial building block in this process.

The aim of this paper was to assess the role of innovations in weather service provision to reduce the negative impacts of climate change-induced increase in the frequency and severity of extreme weather events in the road transport sector from the perspective of the vehicle driver.

It is clear that the potential value of weather service provision has not been fully realised. Investments in research and development, leading to innovations, were shown to be beneficial in terms of increase in the avoided accident cost. These innovations are examples of the improvements in the weather service chain which will significantly decrease the vulnerability of road transport to extreme weather event and the weather related costs, thus being an important part of the sector's climate change adaptation process. Innovations enhance automatic adaptation capabilities which thereby extend the coping range of the road transport system. In turn this allows us to better exploit learning options and thereby invest later on more effectively in adaptation measures. The benefits of the innovations are naturally dependent on the overall development of society and the climate.

The first limitation of the analysis presented in this paper is the knowledge gap of the impacts of climate change on the transport sector, and consequently the lack of estimates related to the accident rates and costs in future climate and society. Paradoxically, it stems from the same reasons as the suggested need for the robust, no-regret adaptation options.

Another limitation of the analysis is related to the qualitative nature of the WSCA and resulting need to estimate the quantitative level of each step based occasionally only on qualitative data. However, WSCA is a comprehensive tool as it enables to assess the full weather service provision chain from the generation of the information all the way to the end used response and resulting benefits. The development of the WSCA is leading toward quantitative indicators with objective criteria to assess the current status and the development need of each step. This would enable the use of the approach in multiple contexts and more objective estimates of the benefits and development needs. The benefit estimates could be used in cost benefit assessments of selected investments.

\section{Acknowledgements}

This study has been conducted as part of the EU FP7 TopDAd project, grant agreement 308620, which aims to model the impacts of climate change and identify adaptation options for the energy, tourism and transport sectors through an ensemble of climate, sector economic and macro-economic models. We thank the three anonymous peer-reviewers for their valuable comments, which substantially improved the quality of the paper, and David Lazarevic for his comments on the manuscript. 


\section{References}

Andersson, A. K. (2010) Winter road conditions and traffic accidents in Sweden and UK: present and future climate scenarios. Thesis for the Degree of Doctor of Philosophy. Dept. of Earth Sciences, Physical Geography, Faculty of Science, University of Gothenburg. Available at: http:/ /hdl.handle.net/2077/21547

Andersson, A. K. and Chapman, L. (2011) 'The impact of climate change on winter road maintenance and traffic accidents in West Midlands, UK', Accident Analysis \& Prevention, Vol. 43, no.1, pp. 284-289

Browning, K. A. (1980) 'Review Lecture: Local Weather Forecasting', Proceedings of the Royal Society of London A: Mathematical, Physical and Engineering Sciences, Vol. 371, no.1745, pp. 179-211

Carter, T., Parry, M., Harasaza, H. and Nishioka, S. (1994) ‘IPCC Technical Guidelines for Assessing Climate Change Impacts and Adaptations', p. 59. Available at: http://ipcc.ch/pdf/specialreports/ipcc-technical-guidelines-1994n.pdf

Cavin, R. K., Lugli, P. and Zhirnov, V. V. (2012) 'Science and Engineering Beyond Moore's Law', Proceedings of the IEEE, Vol. 100, no.Special Centennial Issue, pp. 1720-1749

Chung, E., Ohtani, O., Warita, H., Kuwahara, M. and Morita, H. (2005) 'Effect of rain on travel demand and traffic accidents', in Intelligent Transportation Systems, 2005. Proceedings. 2005 IEEE. IEEE, pp. 1080-1083.

Available at:

http:/ /ieeexplore.ieee.org.libproxy.helsinki.fi/xpls/abs_all.jsp?arnumber=1520201

Clark, L. (2012) 'Netherlands Highways Will Glow in the Dark Starting Mid-2013', Wired. Available at: http:/ / www.wired.com/2012/10/glowing-roads/ (Accessed 8.7.2014)

Cook, A. J., Tanner, G. and Anderson, S. (2004) 'Evaluating the true cost to airlines of one minute of airborne or ground delay: final report'. European Organisation for the Safety of Air Navigation, p. 260. Available at: http://westminsterresearch.wmin.ac.uk/17/1/Cook,Tanner,Anderson_2004_final.pdf

Cools, M. and Creemers, L. (2013) 'The dual role of weather forecasts on changes in activity-travel behavior', Journal of Transport Geography, Vol. 28, , pp. 167-175

Dessai, S. and Hulme, M. (2007) 'Assessing the robustness of adaptation decisions to climate change uncertainties: A case study on water resources management in the East of England', Global Environmental Change, Vol. 17, no.1, p. 59-72

Drews, F. A., Yazdani, H., Godfrey, C. N., Cooper, J. M. and Strayer, D. L. (2009) 'Text Messaging During Simulated Driving', Human factors, Vol. 51, no.5, pp. 762-770

Drobot, S., Chapman, M. B., Anderson, A., Lambi, B., Pisano, P. A. and Guevara, G. (2012) 'Tomorrow's Forecast: Informed Drivers', in Transportation Research E-Circular. Available at: http:/ / trid.trb.org/view.aspx?id=1139494

European Parliament and Council of the European Union (2007) ‘DIRECTIVE 2007/2/EC OF THE EUROPEAN PARLIAMENT AND OF THE COUNCIL of 14 March 2007 establishing an Infrastructure for Spatial Information in the European Community (INSPIRE)', Official Journal of the European Union, Vol. L 108/1, no.COD 2004/0175. Available at: http://eur-lex.europa.eu/legalcontent/EN/TXT/PDF/?uri=CELEX:32007L0002\&from=EN

European Union (2011) 'Intelligent Transport Systems in action'. Luxembourg. Available at: http://www.polisnetwork.eu/uploads/Modules/PublicDocuments/intelligent-transport-systems-inaction_its-action-plan.pdf

Ezell, S. (2010) 'Intelligent Transportation Systems'. The Information Technology \& Innovation Foundation. Available at: http://www.itif.org/files/2010-1-27-ITS_Leadership.pdf

Frei, T., von Grünigen, S. and Willemse, S. (2012) 'Economic benefit of meteorology in the Swiss road transportation sector', Meteorological Applications, Vol. 21, no.2, pp. 294-300

Gillham, B. (2005) Research Interviewing: The Range of Techniques. McGraw-Hill International 
Hallegatte, S. (2009) 'Strategies to adapt to an uncertain climate change', Global Environmental Change, Vol. 19, no.2, pp. 240-247

Harjanne, A. and Ervasti, T. (2014) 'Analysis of user trends and behavior in mobile and online weather and climate services'. Finnish Meteorological Institute, Helsinki, Finland (Reports), p. 59

Hensher, D. and Brewer, A. (2000) Transport: An Economics and Management Perspective. Oxford University Press

Hyvärinen, O. and Saltikoff, E. (2010) 'Social Media as a Source of Meteorological Observations', Monthly Weather Review, Vol. 138, no.8, pp. 3175-3184

Ingham, A., Ma, J. and Ulph, A. (2007) 'Climate change, mitigation and adaptation with uncertainty and learning', Energy Policy, Vol. 35, no.11, pp. 5354-5369

Innamaa, S., Aittoniemi, E., Askola, H. and Kulmala, R. (2012) ‘Roadmap for innovative operation of the transport system'. VTT, Espoo, Finland (VTT TECHNOLOGY), pp. 37

IPCC (2014a) 'Chapter 8 Transport', in Edenhofer, O., Pichs-Madruga, R., Sokona, Y., Farahani, E., Kadner, S., Seyboth, K., Adler, A., Baum, I., Brunner, S., Eickemeier, P., Kriemann, B., Savolainen, J., Schlömer, S., von Stechow, C., Zwickel, T., and Minx, J. . (eds) Climate Change 2014: Mitigation of Climate Change. Cambridge University Press, Cambridge, United Kingdom and New York, NY, USA. (Contribution of Working Group III to the Fifth Assessment Report of the Intergovernmental Panel on Climate Change)

IPCC (2014b) 'Chapter 10. Key Economic Sectors and Services', in Climate Change 2014: Impacts, Adaptation and Vulnerability. Cambridge University Press, Cambridge, United Kingdom and New York, NY, USA (Contribution of Working Group III to the Fifth Assessment Report of the Intergovernmental Panel on Climate Change)

Jaroszweski, D., Chapman, L. and Petts, J. (2010) 'Assessing the potential impact of climate change on transportation: the need for an interdisciplinary approach', Journal of Transport Geography, Vol. 18, no.2, pp. 331-335

Jaroszweski, D. and McNamara, T. (2014) 'The influence of rainfall on road accidents in urban areas: A weather radar approach', Travel Behaviour and Society. (Advances in Spatiotemporal Transport Analysis), Vol. 1, no.1, pp. 15-21

Juga, I. (2012) 'The effect of snowfall and low temperature on road traffic accident rates in Southern Finland', in Proceedings of SIRWEC 16th International Road Weather Conference, Helsinki, Finland, 23-25 May 2012. Available at: http://www.sirwec.org/Papers/helsinki/11.pdf

Jylhä, K., Ruosteenoja, K., Räisänen, J., Venäläinen, A., Tuomenvirta, H., Ruokolainen, L., Saku, S. and Seitola, S. (2009) 'Arvioita Suomen muuttuvasta ilmastosta sopeutumistutkimuksia varten. ACCLIMhankkeen raportti 2009 ((The changing climate in Finland: estimates for adaptation studies. ACCLIM project report 2009)'. Ilmatieteen laitos (Raportteja 2009), p. 102. Available at: https://helda.helsinki.fi/handle/10138/15711

Kates, R. W., Travis, W. R. and Wilbanks, T. J. (2012) 'Transformational adaptation when incremental adaptations to climate change are insufficient', Proceedings of the National Academy of Sciences, Vol. 109, no.19, pp. 7156-7161

Katz, R. W. and Murphy, A. H. (eds) (1997) Economic Value of Weather and Climate Forecasts. Cambridge University Press

Khattak, A. J. and De Palma, A. (1997) 'The impact of adverse weather conditions on the propensity to change travel decisions: a survey of Brussels commuters', Transportation Research Part A: Policy and Practice, Vol. 31, no.3, pp. 181-203

Kilpeläinen, M. and Summala, H. (2007) 'Effects of weather and weather forecasts on driver behaviour', Transportation Research Part F: Traffic Psychology and Behaviour, Vol. 10, no.4, pp. 288-299 
Koetse, M. J. and Rietveld, P. (2009) 'The impact of climate change and weather on transport: An overview of empirical findings', Transportation Research Part D: Transport and Environment, Vol. 14, no.3, pp. 205-221

Laaidi, K. and Laaidi, M. (1997) 'Météorologie et sécurité routière', La Presse thermale et climatique, Vol. 134, no.4, pp. 269-274

Leviäkangas, P., Hautala, R. and Räsänen, J. (2007) 'Benefits of meteorological services in Croatia', p. 81. Available at: http://partnet.vtt.fi/evaserve/evaserve_tool/caset/DHMZ_Croatia_Benefits_final1.pdf

Love, G., Soares, A. and Püempel, H. (2010) 'Climate Change, Climate Variability and Transportation', Procedia Environmental Sciences, Vol. 1, , pp. 130-145

Maze, T. H., Agarwai, M. and Burchett, G. (2006) ‘Whether weather matters to traffic demand, traffic safety, and traffic operations and flow', Transportation research record: Journal of the transportation research board, Vol. 1948, no.1, pp. 170-176

McLaughlin, D. J. and Chandrasekar, V. (2009) 'Short wavelength technology and the potential for distributed networks of small radar systems', in 2009 IEEE Radar Conference, pp. 1-3

Michaelides, S., Leviäkangas, P., Doll, C. and Heyndrickx, C. (2014) ‘Foreward: EU-funded projects on extreme and high-impact weather challenging European transport systems', Natural Hazards, Vol. 72, no.1, pp. 5-22

MMM (2012) ‘Miten väistämättömään ilmastonmuutokseen voidaan varautua? - yhteenveto suomalaisesta sopeutumistutkimuksesta eri toimialoilla (in Finnish)'. (Maa- ja metsätalousministeriön julkaisuja), p. 177

Muller, C. 1., Chapman, L., Johnston, S., Kidd, C., Illingworth, S., Foody, G., Overeem, A. and Leigh, R. r. (2015) 'Crowdsourcing for climate and atmospheric sciences: current status and future potential', International Journal of Climatology, p. n/a-n/a

Nilsson, G. (1982) 'The effects of speed limits on traffic accidents in Sweden', in Proceedings of the international symposium on the effects of speed limits on traffic accidents and transport energy use. OECD, Paris, Dublin, pp. 1-8

Nokkala, M., Leviäkangas, P. and Oiva, K. (2012) 'The costs of extreme weather for the European transport system'. VTT Technical Research Centre of Finland, Espoo, Finland, p. 98. Available at: http://ewent.vtt.fi/Deliverables/D4/T36.pdf

Nordhaus, W. (2002) 'Modeling Induced Innovation in Climate-Change Policy, Chapter 8', in Grübler, A., Nakicenovic, N., and Nordhaus, W. (eds) Technological Change and the Environment. A copublication of Resources for the Future and the International Institute for Applied System Analysis (IIASA), Oxford, U.K.

Nurmi, P., Perrels, A. and Nurmi, V. (2013) 'Expected impacts and value of improvements in weather forecasting on the road transport sector', Meteorological Applications, Vol. 20, no.2, pp. 217-223

Nurmi, V., Perrels, A., Nurmi, P., Michaelides, S., Athanasatos, S. and Papadakis, M. (2012) ‘Economic value of weather forecasts on transportation-Impacts of weather forecast quality developments to the economic effects of severe weather'. Available at: http://ewent.vtt.fi/Deliverables/D5/D5_2_16_02_2012_revised_final.pdf

De Palma, A. and Rochat, D. (1999) 'Understanding individual travel decisions: results from a commuters survey in Geneva', Transportation, Vol. 26, no.3, pp. 263-281

Perkins, S. E., Alexander, L. V. and Nairn, J. R. (2012) 'Increasing frequency, intensity and duration of observed global heatwaves and warm spells', Geophysical Research Letters, Vol. 39, no.20, p. L20714

Perrels, A., Harjanne, A., Nurmi, V., Pilli-Sihvola, K., Heyndricx, C. and Stahel, A. (2013a) 'Sector specific and generic impacts of enhanced weather and climate services in a changing climate' ToPDAd Deliverable 2.2 
Perrels, A., Frei, T., Espejo, F., Jamin, L. and Thomalla, A. (2013b) 'Socio-economic benefits of weather and climate services in Europe', Adv. Sci. Res., Vol. 10, , pp. 65-70

Petty, K. R. and Mahoney, W. P. (2007) 'Enhancing Road Weather Information Through Vehicle Infrastructure Integration', Transportation Research Record, Vol. 2015, no.-1, pp. 132-140

Polak, J. and Heertje, A. (eds) (1993) European Transport Economics. 40 Anv edition. Blackwell Pub, Oxford, UK ; Cambridge, Mass., USA

Qiu, L. and Nixon, W. (2008) 'Effects of Adverse Weather on Traffic Crashes: Systematic Review and Meta-Analysis', Transportation Research Record: Journal of the Transportation Research Board, Vol. 2055, no.1, pp. 139-146

Rajzak, J., Pall, P., Schär, C. (2013), 'Projections of extreme precipitation events in regional climate simulations for Europe and the Alpine Region', Journal of Geophysical Research: Atmospheres, Vol. 118, Issue 9, pp. 3610-3626

Roine, M. (2010) 'ITS Deployment in the future'. (ROADIDEA Deliverable). Available at: http://www.transport-

research.info/Upload/Documents/201204/20120411_171130_45004_ROADIDEA\%20D4.6\%20ITS\%20 Deployment\%20in\%20the\%20Future\%20V1.1.pdf

Rossetti, M. A. (2007) 'Analysis of Weather Events on US Railroads', 23rd Conference on IIPS, Vol. 4a. 2, . Available at: http://ntl.bts.gov/lib/47000/47000/47093/118791.pdf

Rotmans, J. and Loorbach, D. (2009) 'Complexity and Transition Management', Journal of Industrial Ecology, Vol. 13, no.2, pp. 184-196

Rämä, P. and Kulmala, R. (2000) 'Effects of variable message signs for slippery road conditions on driving speed and headways', Transportation Research Part F: Traffic Psychology and Behaviour, Vol. 3, no.2, pp. 85-94

Scheider, T., Newton, D., Öörni, R. and Kellermann, A. (2010) 'Report on service benefits and costs'. (Deliverable 2 of QUANTIS)

Sihvola, N. and Rämä, P. (2008) 'Drivers' perceptions of driving conditions and information about these conditions - road side interviews during winter circumstances (in Finnish)'

Silver, A. (2014) 'Watch or warning? Perceptions, preferences, and usage of forecast information by members of the Canadian public', Meteorological Applications. Available at: http://onlinelibrary.wiley.com.libproxy.helsinki.fi/doi/10.1002/met.1452/full

Smit, B., Burton, I., Klein, R. J. T. and Wandel, J. (2000) 'An Anatomy of Adaptation to Climate Change and Variability', Climatic Change, Vol. 45, no.1, pp. 223-251

Stahel, A., Ciari, F. and Axhausen, K. W. (2014) 'Modeling impacts of weather conditions in agentbased transport microsimulations', in Transportation Research Board 93rd Annual Meeting. Washingon, D.C. Available at: http://assets.conferencespot.org/fileserver/file/64204/filename/14-2668.pdf

Thordarson, S. (2006) 'Traffic safety on wind-exposed roads in Iceland', Nordic Road and Transport Research, no.2. Available at: http:/ / trid.trb.org/view.aspx?id=804344

Ukkusuri, S. V. and Ramadurai, G. (2009) 'Comprehensive Review of Emerging Technologies for Congestion Reduction and Safety', Transportation Research Record: Journal of the Transportation Research Board, Vol. 2129, no.-1, pp. 101-110

Vajda, A., Tuomenvirta, H., Jokinen, P., Luomaranta, A., Makkonen, L., Tikanmäki, M., Groenemeijer, P., Saarikivi, P., Michaelides, S., Papadakis, M., Tymvios, F. and Athanasatos, S. (2011) Probabilities of adverse weather affecting transport in Europe climatology and scenarios up to the 2050s. Finnish Meteorological Institute, Helsinki, REPORTS, 2011:9

WIST (2002) 'Weather information for surface transportation - National Needs Assessment Report'. Office of the Federal Coordinator for Meteorological Services and Supporting Research, Washington, D.C. Available at: http://www.epa.gov/amad/Library/AnnualReports/2001.html 
EJTIR 16(1), 2016, pp.150-173

Pilli-Sihvola, Nurmi, Perrels, Harjanne, Bösch and Ciari

Innovations in weather services as a crucial building block for climate change adaptation in road transport

WMO (2012) 'Socio-economic benefits of hydro-meteorological services - The benefits of showing the benefits'. (WMO RA VI Working Group on Service Delivery \& Partnership Task Team SocialEconomic Benefits (TT-SEB)) 
FINNISH METEOROLOGICAL INSTITUTE

Erik Palménin aukio 1

P.O. Box 503

FI-00560 HELSINKI

tel. +358 295391000

\section{WWW.FMI.FI}

FINNISH METEOROLOGICAL INSTITUTE CONTRIBUTIONS No. 168

ISSN 0782-6117

ISBN 978-952-336-113-3 (paperback)

ISBN 978-952-336-114-O (pdf)

https://doi.org/10.35614/isbn.9789523361140

$\because \because \cdots$
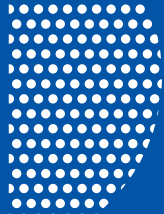

$\because \because{ }^{\prime}$
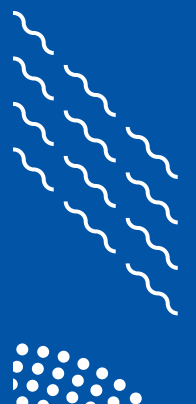

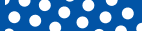

